\title{
The Flammability Analysis and Time to Reach Lower Flammability Limit Calculations on the Waste Evaporation at 242-A Evaporator
}

\author{
T. A. Hu \\ CH2M HILL Hanford Group, Inc. \\ Richland, WA 99352 \\ U.S. Department of Energy Contract DE-AC27-99RL14047

$\begin{array}{lll}\text { EDT/ECN: } & 725053 & \text { UC: } \\ \text { Cost Center: } & 7 \mathrm{~T} 600 & \text { Charge Code: } 502292 \\ \text { B\&R Code: } & \text { N/A } & \text { Total Pages: } / 25\end{array}$

Key Words: Hydrogen Generation Rate; Evaporatore 242-A; Flammability; Time to 25\% of the LFL

Abstract: This document describes the analysis of the waste evaporation process on the flammability behavior. The evaluation calculates the gas generation rate, time to reach $25 \%$ and $100 \%$ of the lower flammability limit (LFL), and minimum ventilation rates for the 242-A Evaporator facility during the normal evaporation process and when vacuum is lost. This analysis performs flammability calculations on the waste currently within all 28 double-shell tanks (DST) under various evaporation process conditions to provide a wide spectrum of possible flammable gas behavior. The results of this analysis are used to support flammable gas control decisions and support and upgrade to Documented Safety Analysis for the 242-A Evaporator.

TRADEMARK DISCLAIMER. Reference herein to any specific commercial product, process, or service by trade name, trademark, manufacturer, or otherwise, does not necessarily constitute or imply its endorsement, recommendation, or favoring by the United States Government or any agency thereof or its contractors or subcontractors.

Printed in the United States of America. To obtain copies of this document, contact: Document Control Services, P.O. Box 950, Mailstop H6-08, Richland WA 99352, Phone (509) 372-2420; Fax (509) 376-4989.

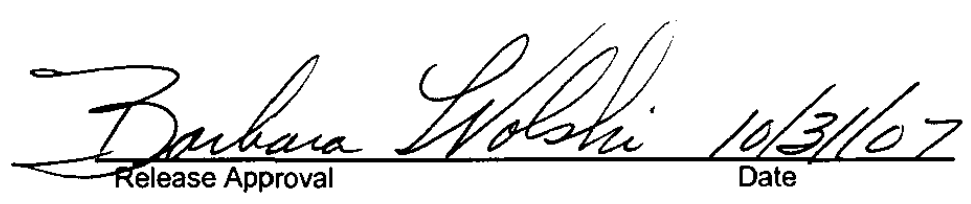

Approved For Public Release

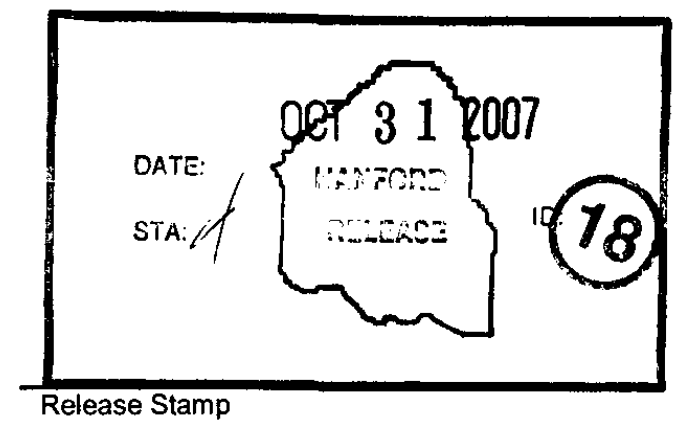




\section{The Flammability Analysis and Time to Reach Lower Flammability Limit Calculations on the Waste Evaporation at 242-A Evaporator}

T. A. $\mathrm{Hu}$

CH2M HILL Hanford Group, Inc.

Date Published

October 2007

Prepared for the U.S. Department of Energy

Assistant Secretary for Environmental Management

Contractor for the U.S. Department of Energy

Office of River Protection under Contract DE-AC27-99RL14047

\section{CH2MIHILL \\ Hanford Group, Inc.}

P.O. Box 1500

Richland, Washington 


\section{Tank Farm Contractor (TFC) \\ RECORD OF REVISION}

(1) Document Number:

RPP-CALC-29700 Rev 1

Page 1

(2) Title:

The Flammability Analysis and Time to Reach Lower Flammability Limit Calculations on the Waste Evaporation at 242-A Evaporator

Change Control Record

(3)

(4) Description of Change - Replace, Add, and Delete Pages

(5) Resp. Engr. (print/sign/date)

Revision

\begin{tabular}{l|l}
0 & Original Release via EDT 822197, June 29, 2006
\end{tabular}

T. A. Hu

$6 / 29 / 2006$

Authorized for Release

1 Revision via ECN $725053 \mathrm{Rev} 0$ to documents the

RS update of AFA analysis and adds Appendix D and E to

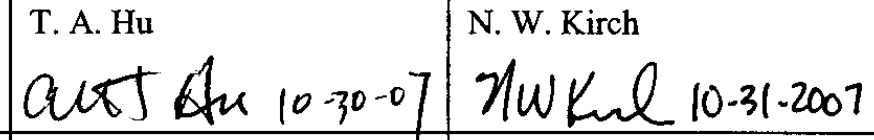

support the 242-A Evaporator DSA amendments

\begin{tabular}{|l|l|l|l|}
\hline & & & \\
\hline & & & \\
\hline & & & \\
\hline & & & \\
\hline & & & \\
\hline & & & \\
\hline
\end{tabular}




\section{CONTENTS}

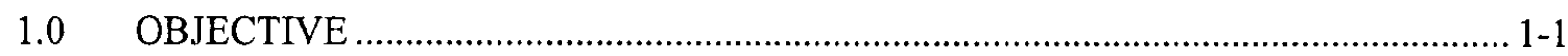

2.0 SUMMARY AND CONCLUSIONS ……………................................................... 2-1

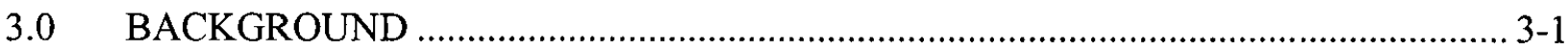

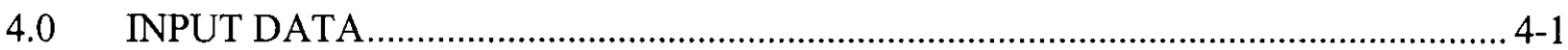

4.1 WASTE PROPERTIES ……………….....................................................

$4.2 \quad$ FACILITY DIMENSIONS.................................................................... 4-2

$5.0 \quad$ ASSUMPTIONS

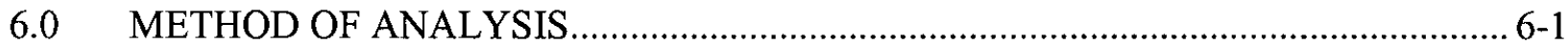

6.1 RATE EQUATIONS FOR HYDROGEN GENERATION .............................. 6-1

6.2 EQUILIBRIUM GAS TRANSPORT RATE ................................................... 6-3

6.3 TIME-DEPENDENT GAS CONCENTRATION MODEL_................................. 6-4

6.4 FLAMMABILITY LEVEL MODEL CALCULATION................................. 6-7

6.5 FLAMMABILITY ANALYSIS FOR THE PROCESS UNDER LOW

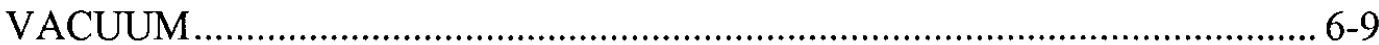

7.0 USE OF COMPUTER SOFTWARE

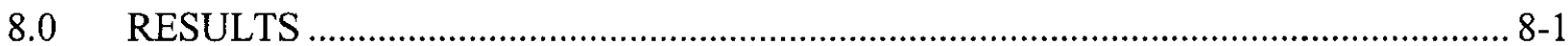

8.1 FLAMMABILITY LEVEL ON C-A-1 UNDER AMBIENT PRESSURE ........ 8-1

8.2 FLAMMABILITY LEVEL ON TK-C-100 UNDER AMBIENT PRESSURE........................................................................................ 8-10

8.3 FLAMMABILITY LEVEL ON GASEOUS EFFLUENT AFTER PRIMARY CONDENSER UNDER VACUUM.............................................. 8-13

9.0 CONCLUSIONS

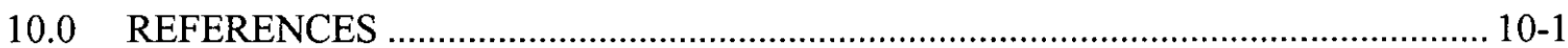


RPP-CALC-29700 REV 1

\section{APPENDICES}

A INPUT DATA FOR HYDROGEN GENERATION RATES AND AMMONIA EQUILIBRIUM CALCULATIONS ………………........................................ A-i

B FLAMMABILITY ANALYSIS RESULTS ON EVAPORATOR VESSEL C-A-1 ...... B-i

C FLAMMABILITY ANALYSIS RESULTS ON CONDENSATE TANK

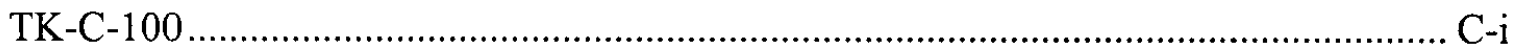

D FLAMMABILITY ANALYSIS FOR 242-A EVAPORATOR CAMPAIGNS 07-01 AND 07-02 D-i

E FLAMMABILITY ANALYSIS FOR 242-A EVAPORATOR UNDER SHUTDOWN MODE AND WATER STARTUP OPERATION ... $\mathrm{E}$

F ESTIMATE OF CARBON FRACTION IN DOW CORNING 1520 SILICONE ANTIFOAM F-i

G TECHNICAL BASIS WHY ASSUMING ONE DRUM OF ANTIFOAMING AGENT IN THE C-A-1 EVAPORATOR VESSEL IS REASONABLY CONSERVATIVE. G-i

H CALCULATION REVIEW CHECKLIST $\mathrm{H}-\mathrm{i}$ 
RPP-CALC-29700 REV 1

\section{LIST OF FIGURES}

Figure 3-1. 242-A Evaporator Process Flowsheet (Taken from HNF-14755). $3-2$

Figure 4-1. Layout of Evaporator Vessel C-A-1 and Its Gaseous Effluent Pathway for Dimensions Calculation.

Figure 6-1. The Model of Waste Volume Fraction. $6-5$

Figure 6-2. Steam Jet Ejector and Three Stages of Condensers (taken from HNF-14755)..... 6-11

Figure 8-1. Time to $25 \%$ of the Lower Flammability Limit Versus Target Slurry SpG.

Figure $8-2$. Time to $25 \%$ of the Lower Flammability Limit Versus Temperature. $8-4$

\section{LIST OF TABLES}

Table 4-1. Dimensions, Surface Area and Volume of Evaporator Vessel C-A-1

Table 4-2. Extended Vapor Space Volume Beyond Vessel C-A-1 Headspace.

Table 4-3. Dimensions, Volume, and Surface Area of Condensate Tank TK-C-100. 4-6

Table $8-1$. Time to $25 \%$ of the Lower Flammability Limit for the Top Five Tanks.

Table 8-2. Summary of Time to $25 \%$ of the Lower Flammability Limit as Function of Temperature.

Table 8-3. Summary of the Time to $25 \%$ of Lower Flammability Limit Under Zero Vent for Evaporator Campaign 07-01 and 07-02.

Table 8-4. Total Organic Carbon and Time to $25 \%$ of the Lower Flammability Limit Calcuations With and Without Feed Antifoam Agent

Table 8-5. Summary of Time to $25 \%$ of the Lower Flammability Limit for the Shutdown and Startup Modes.

Table 8-6. Measured Ammonia Concentration in Condensate Tank TK-C-100.

Table 8-7. Steady-State Flammability and Time to Lower Flammability Limit for TK-C-100 of 242-A Evaporator.

Table 8-8. Parameters Used in the Flammability Analysis on C-A-1 Under Vacuum Condition. 
RPP-CALC-29700 REV 1

Table 8-9. Flammability of the Gaseous Effluent After Primary Condenser with Air InLeakage $8-15$ 


\section{LIST OF TERMS}

AFA

$\mathrm{BB}$ or $\mathrm{bb}$

DSA

DST

HGR

LFL

$\mathrm{SpG}$

SST

TOC

TWINS antifoaming agent

barometric breathing

HNF-14755, Documented Safety Analysis for the 242-A

Evaporator

double-shell tank

hydrogen generation rate

lower flammability limit

specific gravity

single-shell tank

total organic carbon

Tank Waste Information Network System 
RPP-CALC-29700 REV 1

This page intentionally left blank. 


\subsection{OBJECTIVE}

The 242-A Evaporator is the primary facility at the Hanford Site for waste volume reduction through the evaporation process on low specific gravity $(\mathrm{SpG})$ supernatant waste. This evaluation calculates the gas generation rate, time to reach $25 \%$ and $100 \%$ of the lower flammability limit (LFL), and minimum ventilation rates for the 242-A Evaporator facility during the normal evaporation process and when vacuum is lost. This analysis performs flammability calculations on the waste currently within all 28 double-shell tanks (DST) under various evaporation process conditions to provide a wide spectrum of possible flammable gas behavior. The results of this analysis are used to support flammable gas control decisions and support and upgrade to HNF-14755, Documented Safety Analysis for the 242-A Evaporator (DSA). In addition, a flammability analysis is included for the flammable gas detonation issue using bounding process conditions. This result is used to support an upgrade to the fire hazard evaluation. 
RPP-CALC-29700 REV 1

This page intentionally left blank. 
RPP-CALC-29700 REV 1

\subsection{SUMMARY AND CONCLUSIONS}

Analyses for steady-state flammability and time to reach the $25 \%$ and $100 \%$ of the LFL are performed under barometric breathing and zero ventilation for the 242-A Evaporator facility. Three structures are identified for detailed flammability analysis: the C-A-1 evaporator vessel; its gaseous effluent pathways; and condensate tank TK-C-100. Both normal conditions (i.e., under vacuum) and off-normal (i.e., ambient pressure) conditions were considered.

This analysis adopts the methodology of flammability evaluation developed for the DST and single-shell tank (SST) waste as documented in RPP-8050, Lower Flammability Limit Calculations for Catch Tanks, IMUSTs, DST Annuli, Pit Structures, and Double-Contained Receiver Tanks in Tank Farms at the Hanford Site; RPP-5926, Steady-State Flammable Gas Release Rate Calculation and Lower Flammability Level Evaluation for Hanford Tank Waste; and HNF-3851, Empirical Rate Equation Model and Rate Calculations of Hydrogen Generation for Hanford Tank Waste. The analysis considered the current waste of all 28 DSTs at various operating temperatures ranging from 120 to $160^{\circ} \mathrm{F}$ and concentrated slurry SpG from 1.5 to 1.7. In addition, the times to reach 30 volume percent of hydrogen under no ventilation are calculated for the limiting tank waste of DST 241-AN-102 at temperature of $155^{\circ} \mathrm{F}$ and concentrated slurry SpG of 1.6.

From the evaluations, it can be concluded that with waste in the evaporator vessel at ambient pressure and at the bounding operational temperature, the headspace of vessel C-A-1 can reach $25 \%$ of the LFL in 1 day for the bounding concentrated tank waste under zero ventilation conditions. Also, during the normal operation at high vacuum and operational temperature the headspace of vessel C-A-1 will have no flammability concern; but the gaseous effluent pathway flammability after the primary condenser may reach $58 \%$ of the LFL for current waste from the bounding DST. In addition, the evaluation shows that the condensate tank TK-C-100 will not reach $25 \%$ of LFL even when filled to the overflow ( $85 \%$ full) under barometric breathing, but it will reach $25 \%$ of the LFL in 432 days under zero ventilation conditions.

Revision 1 of this document:

- Updates the analysis for the addition of antifoaming agents (AFA) to the waste in Chapter 8.0, Section 8.1.

- Documents the flammability analysis for the 242-A Evaporator campaign 07-01 and 07-02 in Appendix D.

- Documents the flammability analysis for the shutdown mode and the startup operation of evaporator process prior to the liquid waste feed in Appendix E. 
RPP-CALC-29700 REV 1

This page intentionally left blank. 


\subsection{BACKGROUND}

The 242-A Evaporator is designed to reduce waste volume and the number of DSTs required to store liquid waste generated at the Hanford Site. The process uses a conventional, forced-circulation, vacuum evaporation system operating at low pressure (approximately 60 torr) and high temperature (approximately $50^{\circ} \mathrm{C}\left[122^{\circ} \mathrm{F}\right]$ ) to concentrate radioactive waste solutions.

A process flowsheet is shown in Figure 3-1. The waste feed is pumped from feed tank 102-AW through an underground-encased feed line to the 242-A Evaporator and subsequently into vessel C-A-1 for processing. The waste feed is concentrated in vessel C-A-1 to a specified waste concentration creating product slurry (at a target $\mathrm{SpG}$ ) and water (plus other gases) vapor.

The slurry is transferred from the 242-A Evaporator through underground-encased piping to 241-AW-A or 241-AW-B valve pits in the 241-AW Tank Farm. The slurry is routed to other DSTs in the 200 East Area. Process offgases and water vapor are passed through one primary and two secondary condensers, creating the process condensate and a gaseous effluent. Gaseous effluents are filtered and released to the environment from the vessel ventilation exhaust system. Process condensate is collected in condensate collection tank TK-C-100 and pumped directly to the Liquid Effluent Retention Facility via the P-C-5000 transfer line or used in the process condensate recycle system.

In this flammability analysis, two major components, Evaporator Vessel C-A-1 and Condensate Collection Tank TK-C-100, are identified to be evaluated under both normal and off-normal conditions. In the normal condition, full operation is defined as when the waste is fed into evaporator vessel under low vacuum (pressure ranging 40 to 80 torr) and the boiler heating the waste (temperature ranging 120 to $150^{\circ} \mathrm{F}$ ). The off-normal condition is defined as losing vacuum condition (i.e., ambient pressure) while the waste still remains in the system. Waste recirculation without vacuum, unexpected system shutdown during the evaporation process, or system shutdown after the evaporation process are considered off-normal conditions.

Under normal conditions, the water vapor along with any flammable gas (such as hydrogen, methane and ammonia) that is generated in the headspace of C-A-1 is passed through the condensers to the vessel ventilation exhaust system or process condensate. However, during this normal low-vacuum operation, air is introduced into the system through in-leakage right after the primary condenser E-C-1. This in-leakage is used to control the pressure of vacuum by adjusting the flow rate of air to the system. The air-flammable gas mixture is created after the air is introduced under the normal operation. For the off-normal condition, after a short transition from vacuum condition, the system is under ambient pressure. Flammability analysis on C-A-1 and its gaseous effluent pathway is performed under the normal and off-normal operating condition.

For the condensate tank TK-C-100, the major contents are the condensate water plus soluble gas ammonia, which will produce flammable gas in the headspace. A flammability analysis on TK-C-100 was performed. 
Piping Abbreviations

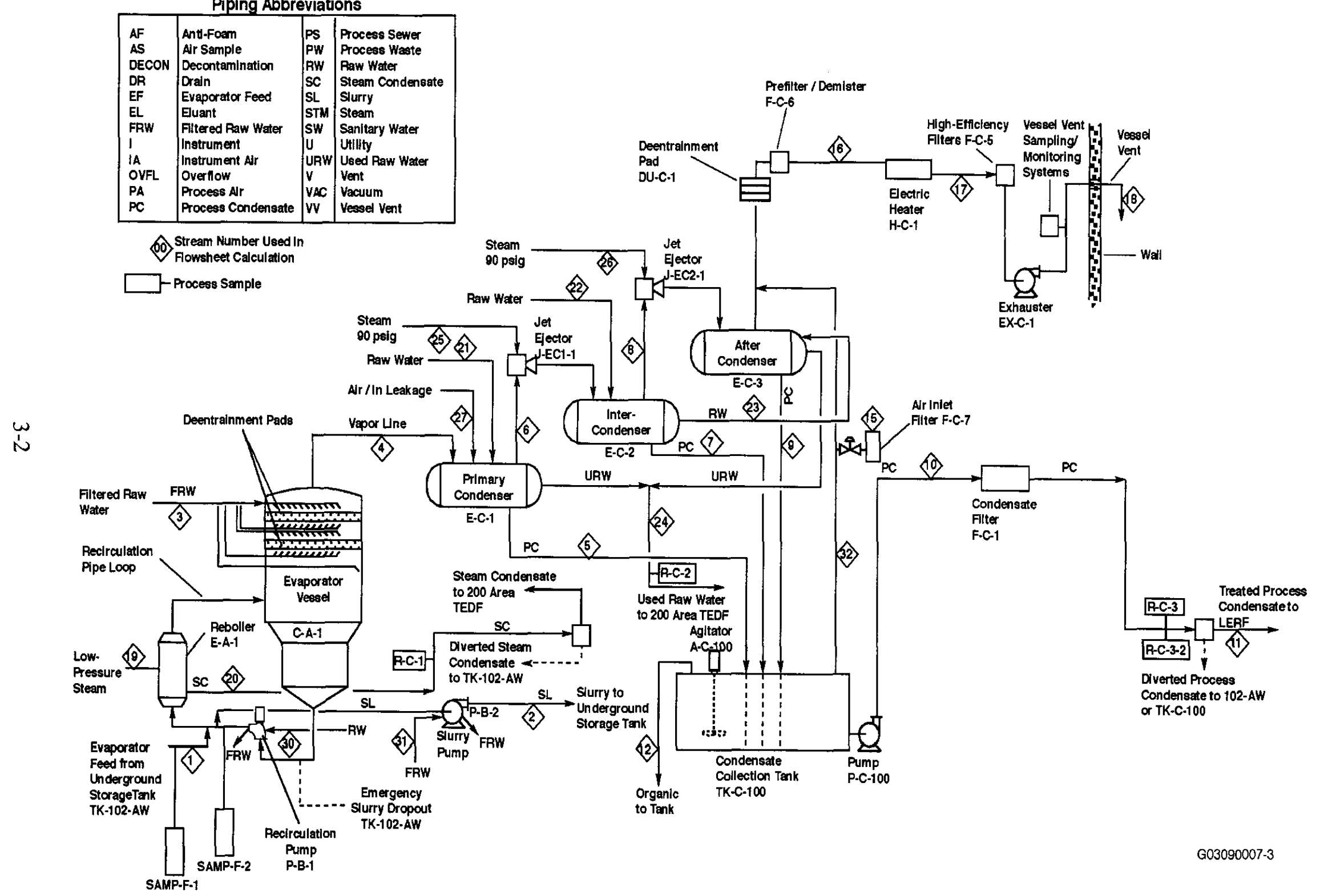




\subsection{INPUT DATA}

The steady-state flammability evaluations use the same methodology and spreadsheet developed for RPP-8050. The required input data for the spreadsheet includes the unit gas rates, waste properties, and the dimensions and properties of the tank containing the waste. The unit rate of gas generation and gas transport properties for waste from all $28 \mathrm{DST}$ at various temperatures and targeted slurry SpG are calculated using the spreadsheet developed for RPP-5926.

\subsection{WASTE PROPERTIES}

The input data to calculate the unit gas generation rate and gas transport properties of waste under current conditions for the 28 DSTs is taken from RPP-5926, Rev. 5, Appendix B, Table B-1, and Appendix C, Table C-1, and are listed in Appendix A, Table A-1. The ammonia data was updated from the Tank Waste Information Network System (TWINS) database in May 2006. The available ammonia data are compiled and listed in Appendix A, Table A-2.

To convert the input data for unit gas rates and gas transport properties calculation from the raw waste condition to the condition of targeted slurry $\mathrm{SpG}$, the following model equations are derived.

Assume the volume of water lost through evaporation is additive with the waste volume. After water is lost through evaporation, the slurry volume is reduced from Vo to $\mathrm{V}$, the slurry density $\rho$, as the balance of mass, can be expressed as follows (Equation 4-1):

$$
\rho=\left[\frac{\rho_{0} V_{0}-\rho_{w}\left(V_{0}-V\right)}{V}\right]
$$

where $\rho_{0}$ and $\rho_{w}$ are the density of initial slurry density and water density, respectively.

Now define the evaporation concentrating ratio $\mathrm{C}_{\mathrm{R}}$ as $\mathrm{V}_{0} / \mathrm{V}$. It can be expressed in terms of the densities by rearranging Equation 4-1 to obtain the expression of $V_{0} / V$ as follows (Equation 4-2):

$$
C_{R}=\frac{V_{0}}{V}=\frac{\rho-\rho_{w}}{\rho_{0}-\rho_{w}}
$$

The chemical concentration after evaporation concentration can be expressed in terms of initial chemical concentration and densities as Equation 4-3:

$$
C=\frac{C_{0} V_{0}}{V}=C_{0} \frac{\rho-\rho_{w}}{\rho_{0}-\rho_{w}}
$$


Note that volatile chemicals such as ammonia will not be concentrated as above but are governed by Henry's Law reaching the equilibrium between liquid and gas phase. For the radionuclide, since its raw input data is in the unit of micro curie per gram, thus the radionuclide concentration $\mathrm{N}$ can be expressed as Equation 4-4:

$$
N=\frac{N_{0} \rho_{0} V_{0}}{\rho V}=N_{0} \frac{\rho_{0}\left(\rho-\rho_{w}\right)}{\rho\left(\rho_{0}-\rho_{w}\right)}
$$

where $\mathrm{N}_{0}$ is the initial radionuclide concentration.

The weight fraction of water $\mathrm{W}$ can be derived as follows (Equation 4-5):

$$
W=\frac{W_{0} \rho_{0} V_{0}-\rho_{w}\left(V_{0}-V\right)}{\rho V}=\frac{\rho_{w}}{\rho}+\left(\frac{\rho W_{0}-\rho_{w}}{\rho}\right) \frac{\rho-\rho_{w}}{\rho_{0}-\rho_{w}}
$$

where the $\mathrm{W}_{0}$ is the initial weight fraction of water. For a given initial $\mathrm{SpG}$ of the supernatant waste and the targeted concentrated slurry $\mathrm{SpG}$, the final chemical concentration (nonvolatile), radionuclide, and weight fraction of water can be calculated at the targeted slurry SpG using Equations 4-1 through 4-5.

The input data from Tables A-1a, A-1b, A-1c, and A1-d, are converted to the target slurry SpG of 1.6 using Equations 4-1 through 4-5 and the results are listed in Appendix A, Tables A-3a, $\mathrm{A}-3 \mathrm{~b}, \mathrm{~A}-3 \mathrm{c}$. The ammonia is volatile and its concentration remaining in the liquid is governed by the equilibrium between liquid and gas phases. From the sample results comparing the concentration of feed and target slurry, the slurry remains 10 to $21 \%$ of the feed ammonia. In the off-normal condition calculations, $30 \%$ is used as a bounding ammonia concentration.

\subsection{FACILITY DIMENSIONS}

The dimensions of the facility are needed to determine the headspace volume, surface area, and wetted surface of the system. Figure 4-1 is a drawing of the evaporator vessel C-A-1 and its gaseous effluent pathway referenced in the dimension calculations. The layout of evaporator vessel can be broken down into seven parts: top head (A), upper shell (B), upper cone (C), lower shell $(D)$, lower cone $(E)$, recirculation $(F), 42$-in. pipeline $(G)$, primary condenser $(H)$. 


\section{RPP-CALC-29700 REV 1}

Figure 4-1. Layout of Evaporator Vessel C-A-1 and Its Gaseous Effluent Pathway for Dimensions Calculation.
A. Top Head
B. Upper Shell
C. Upper Cone
D. Lower Shell
E. Lower Cone
F. Recirculation
G. 42-in. Pipeline
H. Primary Condenser

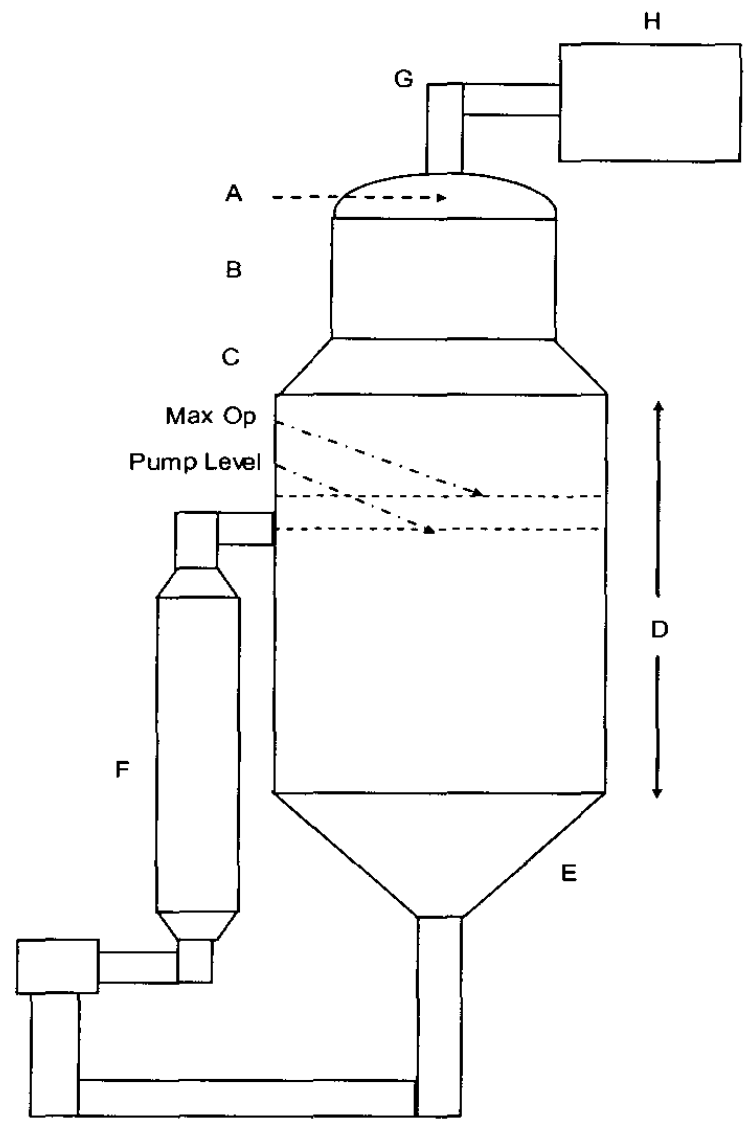

Detail dimensions of the evaporator vessel are given in RPP-18465, Technical Basis for the 242-A Evaporator Operating Specifications. Tables 4-1 and 4-2 list the information for the evaporator vessel and the extended headspace volume from the gaseous effluent pathway, respectively.

Table 4-1. Dimensions, Surface Area and Volume of Evaporator Vessel C-A-1. (2 sheets)

\begin{tabular}{|c|c|c|c|}
\hline Parts & Description & Values $^{2}$ & Units \\
\hline \multirow[t]{2}{*}{ A } & Top head volume & $\begin{array}{l}213,906 \\
926\end{array}$ & $\begin{array}{l}\text { cubic inch }{ }^{\mathrm{c}} \\
\text { gallon }\end{array}$ \\
\hline & Wet surface area & 18,265 & square inch $^{\mathrm{b}}$ \\
\hline \multirow{5}{*}{$\mathrm{E}$} & Radius of base for lower cone & 83.625 & inch \\
\hline & Radius of top for lower cone & 13.625 & inch \\
\hline & Height of lower cone & 121.25 & inch \\
\hline & Lower cone surface area & 43,104 & square inch ${ }^{b}$ \\
\hline & Lower cone volume & $\begin{array}{l}1,056,181 \\
4,572\end{array}$ & $\begin{array}{l}\text { cubic inch } \\
\text { gallon }\end{array}$ \\
\hline
\end{tabular}




\section{RPP-CALC-29700 REV 1}

Table 4-1. Dimensions, Surface Area and Volume of Evaporator Vessel C-A-1. (2 sheets)

\begin{tabular}{|c|c|c|c|}
\hline Parts & Description & Values $^{2}$ & Units \\
\hline \multirow{5}{*}{$\mathrm{C}$} & Radius of base for upper cone & 83.625 & inch \\
\hline & Radius of top for upper cone & 68.625 & inch \\
\hline & Height of upper cone & 26 & inch \\
\hline & Upper cone surface area & 14,428 & square inch $^{\mathrm{b}}$ \\
\hline & Upper cone volume & $\begin{array}{l}474,876.6 \\
2,056\end{array}$ & $\begin{array}{l}\text { cubic inch } \\
\text { gallon }\end{array}$ \\
\hline \multirow{3}{*}{$\mathrm{D}$} & Inner diameter of lower shell (cylinder) & 167.25 & inch \\
\hline & Height of lower shell ${ }^{\mathrm{b}}$ & 216 & inch \\
\hline & Lower shell volume & $\begin{array}{l}4,745,433 \\
20,543\end{array}$ & $\begin{array}{l}\text { cubic inch }^{\mathrm{c}} \\
\text { gallon }\end{array}$ \\
\hline \multirow{3}{*}{ B } & Inner diameter of upper shell (cylinder) & 137.25 & inch \\
\hline & Height of upper shell & 96 & inch \\
\hline & Upper shell volume & $\begin{array}{l}1,420,319 \\
6,149\end{array}$ & $\begin{array}{l}\text { cubic inch }^{\mathrm{c}} \\
\text { gallon }\end{array}$ \\
\hline \multirow{6}{*}{ I } & Length of nozzle \#29 & 20.75 & inch \\
\hline & Inner diameter of nozzle \#29 & 27.25 & inch \\
\hline & Nozzle \#29 volume & $\begin{array}{l}12,102 \\
52 \\
\end{array}$ & $\begin{array}{l}\text { cubic inch }^{\mathrm{c}} \\
\text { gallon }\end{array}$ \\
\hline & Length of nozzle \#2 & 12.19 & inch \\
\hline & Inner diameter of nozzle \#2 & 41.25 & inch \\
\hline & Nozzle \#2 volume & $\begin{array}{l}16,291 \\
71\end{array}$ & $\begin{array}{l}\text { cubic inch }^{\mathrm{c}} \\
\text { gallon }\end{array}$ \\
\hline \multirow[t]{2}{*}{$F$} & Recirculation pipe volume $^{c}$ & $\begin{array}{l}794,586 \\
3,440 \\
\end{array}$ & $\begin{array}{l}\text { cubic inch }^{\mathrm{c}} \\
\text { gallon }\end{array}$ \\
\hline & Recirculation pipe surface & 98,698 & square inch ${ }^{\mathrm{b}}$ \\
\hline \multirow{3}{*}{\multicolumn{2}{|c|}{ Total volume of C-A-1 }} & $8,733,694$ & cubic inch $^{c}$ \\
\hline & & 5,054 & cubic feet \\
\hline & & 37,808 & gallon \\
\hline
\end{tabular}

Notes:

${ }^{a}$ The dimension information is taken from RPP-18465, unless otherwise noted.

${ }^{b}$ The height of lower shell is taken from RPP- 18465 .

${ }^{\mathrm{c}}$ The volume of recirculation is taken from RPP- 18465 .

RPP-18465, 2007, Technical Basis for the 242-A Evaporator Operating Specifications, Rev. 1, CH2M HILL Hanford Group, Inc., Richland, Washington. 
Table 4-2. Extended Vapor Space Volume Beyond Vessel C-A-1 Headspace.

\begin{tabular}{|l|l|l|l|}
\hline Parts & \multicolumn{1}{|c|}{ Description } & \multicolumn{1}{c|}{ Values } & \multicolumn{1}{c|}{ Units } \\
\hline \multirow{4}{*}{$\mathrm{G}$} & $\begin{array}{l}\text { Diameter of 42-in. pipeline between vessel and } \\
\text { primary condenser* }\end{array}$ & 42 & inch \\
\cline { 2 - 5 } & Length of 42-in. pipeline* & 20 & feet \\
\cline { 2 - 5 } & Volume of 42-in. pipeline* & 192 & cubic feet \\
\hline \multirow{4}{*}{ H } & Diameter of primary condenser** & 85 & inch \\
\cline { 2 - 5 } & Length of primary condenser** & 12 & feet \\
\cline { 2 - 5 } & Total volume of primary condenser** & 473 & cubic feet \\
\cline { 2 - 5 } & Diameter of baffle tube inside condenser & 0.75 & inch \\
\cline { 2 - 5 } & Diameter of baffle tube inside condenser & 12 & feet \\
\cline { 2 - 5 } & $\begin{array}{l}\text { Total volume of 2,950 pieces of baffle tube within } \\
\text { condenser for raw water which should be excluded in } \\
\text { the extended head space volume calculation** }\end{array}$ & 109 & cubic feet \\
\hline
\end{tabular}

Notes:

The volume of the pathway after the primary condenser is small and is neglected in the calculation.

* From drawings H-2-69339, H-2-69340, and H-2-69343.

**From certified vendor information [CVI]: file number 20253.

H-2-69339, 1976, Piping Arrangement Evaporator Room Plans, Rev. 2, Vista Engineering, U.S. Atomic Energy Commission, Richland Operations Office, Richland, Washington.

H-2-69340, 1977, Piping Arrangement Evaporator Room Sections, Rev. 3, Vista Engineering, U.S. Atomic Energy Commission, Richland Operations Office, Richland, Washington.

H-2-69343, 1988, Piping Arrangement Condenser Room Section, Rev. 6, Vista Engineering, U.S. Atomic Energy Commission, Richland Operations Office, Richland, Washington.

The maximum operational volume is 26,000 gal (OSD-T-151-00012, Operating Specifications for the 242-A Evaporator, Sec. 2.2.1), which is $15.654 \mathrm{ft}$ from the bottom of the lower shell (component D in Figure 4-1). Given the total volume of C-A-1 is 37,808 gal $\left(5,054 \mathrm{ft}^{3}\right)$ from Table 4-1, the volume of headspace in C-A-1 is 11,808 gal $\left(1,179 \mathrm{ft}^{3}\right)$. The waste surface area, which is the surface area of lower shell, is $152 \mathrm{ft}^{2}$. The required wet surface area, which is the surface area below the waste surface of the maximum operation level, is $1,839 \mathrm{ft}^{2}$ including the surface area of components $\mathrm{E}$ and $\mathrm{F}$, and part of component $\mathrm{D}$. Furthermore, since there is no gate between the headspace and the rest of gaseous effluent pathway, in the calculation the headspace of C-A-1 are expanded to include the 42-in. pipeline (component $\mathrm{G}$ ) and the vapor space of primary condenser (component $\mathrm{H}$ ). The volume of gaseous effluent pathway after primary condenser is small and is neglected in the calculation. Table 4-2 provides the dimension information for the extended vapor space beyond vessel C-A-1 and shows the total extra headspace volume is $557 \mathrm{ft}^{3}$. In the flammability calculation, the total headspace volume used in the calculation becomes $2,135 \mathrm{ft}^{3}$ and the equivalent filled fraction becomes 0.62 instead of 0.69 .

The second facility to be evaluated is condensate tank TK-C-100. It is a straight cylinder with dishes at the top and bottom. The dimensions and calculated volume are given in Table 4-3. 


\section{RPP-CALC-29700 REV 1}

Table 4-3. Dimensions, Volume, and Surface Area of Condensate Tank TK-C-100.

\begin{tabular}{|c|c|c|}
\hline Description & Values & Unit \\
\hline Diameter of the straight cylinder & 14 & feet \\
\hline Height of the straight cylinder & 14 & feet \\
\hline Thickness of the wall & 0.31 & inch \\
\hline Height of the dish (estimated) & 2.8 & feet \\
\hline Volume of vertical straight cylinder & 2139 & cubic feet \\
\hline Estimated volume of dish bottom & 285.2 & cubic feet \\
\hline Estimated volume of dish top & 285.2 & cubic feet \\
\hline Total tank volume & 2710 & cubic feet \\
\hline Surface area of dish (estimated as cylinder) & 275.5 & square feet \\
\hline Waste surface area of straight cylinder & 152.8 & square feet \\
\hline Straight cylinder above overflow & 108.2 & cubic feet \\
\hline Total volume above overflow & 393.4 & cubic feet \\
\hline Fraction of volume above overflow & 0.15 & \\
\hline
\end{tabular}

Note:

The tank dimension is taken from H-2-40704, 1975, Class II Vessel 14 Feet 0 Inch XI4 Feet 0 Inch Tank TK-386, Rev. 4, Kellex Corporation, General Electric Company, Hanford Works, Richland, Washington. 


\section{$5.0 \quad$ ASSUMPTIONS}

In the unit rate calculation, it is assumed that the methane generation unit rate is $10 \%$ of the calculated unit rate of the sum of the radiolysis and thermolysis for hydrogen generation at various tank waste temperatures and moisture contents. In this assumption to estimate methane generation rate, the corrosion portion of hydrogen generation is omitted from the calculation. This is because the hydrogen generation from corrosion is through water, and water will not generate methane.

The sample results of evaporation campaigns 94-2 (WHC-SD-WM-PE-054, 242-A Campaign 94-2 Post Run Document) and 05-01 (RPP-RPT-27963, 242-A Evaporator Campaign 05-01 Vapor Emissions Evaluation, RPP-PLAN-23668, Process Control Plan for 242-A Evaporator Campaign 05-01) show the ammonia concentration in the slurry ranging from $10 \%$ to $21 \%$ of the feed waste. In the flammability calculations for the C-A-1 headspace under ambient pressure, the concentration of ammonia remaining in the evaporator vessel C-A-1 (which is the same as slurry when it reaches steady-state) is conservatively assumed to be $30 \%$ of the ammonia concentration in the feed waste. It is believed that the $30 \%$ should also be a bounding number during the startup (since the evaporator is initially charged with water and waste is slowly injected after the vessel reaches operating temperature and pressure).

In the flammability calculation for the headspace and gaseous effluent of the C-A-1 under vacuum condition, it is conservatively assumed that only $10 \%$ of the ammonia in the feed remains in the vessel and $90 \%$ goes to the headspace; and $8.6 \%$ of the $90 \%$ of the feed ammonia remains in the vapor phase after primary condenser (HNF-14755, Appendix 2B, 8.6\% is the ratio of Stream 6 [vapor line after primary condenser] and Stream 4 [vapor line before primary condenser])

It is assumed that the volume percent of the LFLs for each flammable gas at the high vacuum is the same as at 1 atmosphere. 
RPP-CALC-29700 REV 1

This page intentionally left blank. 


\subsection{METHOD OF ANALYSIS}

In order to help establish flammable gas control criteria, a total of 28 DSTs are modeled and analyzed to characterize the flammable gas behavior of the current liquid waste under the evaporation process in the 242-A Evaporator. The flammability level of the waste is the net contribution from all flammable gases accumulated from the various contributors (e.g., high ammonia concentration, radionuclide inventory, high TOC) from each gas. Therefore, analyzing the waste from all 28 DSTs provides a wide spectrum of waste profiles for understanding the different causes of the flammable gas behavior.

This flammability analysis models the following cases using all 28 DST current wastes.

1. The steady-state flammability level and time to reach specified level of LFL for the evaporator vessel C-A-1 and its gaseous effluent pathway when the system contains waste under the ambient pressure during the unexpected system shutdown, waste recirculation mode, or after the evaporation process has been completed. Flammability calculations are conducted at waste temperatures of $120,130,140,150,155,160^{\circ} \mathrm{F}$ with targeted slurry $\mathrm{SpG}$ of 1.5, 1.55, 1.6, and 1.7. In the calculations, the concentration of ammonia remaining in the evaporator vessel C-A-1 is conservatively assumed to be $30 \%$.

2. The flammability level and time to reach a specified level of LFL for the condensate tank TK-C-100 at various filled levels up to the overflow line. The system is always running under ambient pressure. The analysis calculates the flammability in $10 \%$ increments from $10 \%$ filled to about $85 \%$ filled under waste temperature of $85^{\circ} \mathrm{F}$.

3. The flammability level of the headspace of evaporator vessel C-A-1 and the gaseous effluent pathway after C-A-1 vessel during the normal operation under low vacuum conditions. Flammability calculations are conducted for the gaseous effluent pathway just past the primary condenser for the case of $155^{\circ} \mathrm{F}, \mathrm{SpG}$ of 1.6 and $7.74 \%$ ammonia in the feed (which is the product of $90 \%$ from the feed and $8.6 \%$ surviving after the primary condenser).

For a system under ambient pressure, the flammability analysis uses the methodology developed for the steady-state flammability analysis on 177 DSTs and SSTs and miscellaneous secondary tanks and structures at the Hanford Site. The methodology is documented in detail in HNF-3851, RPP-5926, and RPP-8050, and the equations pertinent to this analysis are described in Sections 6.1 through 6.4. For the system under a low pressure vacuum condition, this flammability analysis uses a simplified and bounded approach rather than a sophisticated and tedious approach for the dynamic flow condition. Details of this dynamic analysis are given in Section 6.5.

\subsection{RATE EQUATIONS FOR HYDROGEN GENERATION}

The empirical rate equation for hydrogen generation in Hanford Site waste contains the simulation of thermal reaction, $\mathrm{HGR}_{\mathrm{thm}}$, radiolysis of water and organic, $\mathrm{HGR}_{\mathrm{rad}}$, and the 


\section{RPP-CALC-29700 REV 1}

corrosion process, $\mathrm{HGR}_{\text {corr }}$. This rate equation is a function of waste composition (TOC, $\mathrm{Al}^{+3}$, $\mathrm{NO}_{3}{ }^{-}, \mathrm{NO}_{2}{ }^{-}, \mathrm{OH}^{-}$and $\mathrm{Na}^{+}$), radiation dose, temperature, liquid fraction, and tank wetted area.

Both the thermal and organic radiolysis rates follow Arrhenius behavior with a derived activation energy. The equation for the hydrogen generation rate (HGR) in the units of moles per kilogram per day can be summarized as follows (Equation 6-1):

$$
H G R=H G R_{t h m}+H G R_{r a d}+H G R_{c o r r}
$$

where:

$$
\begin{aligned}
& H G R_{t h m}=a_{t h m} \times\left(r_{f} \times[T O C]\right) \times\left[\mathrm{Al}^{+3}\right]^{0.4} \times L_{f} \times \exp ^{\left(-E_{t h m} / R T\right)}
\end{aligned}
$$

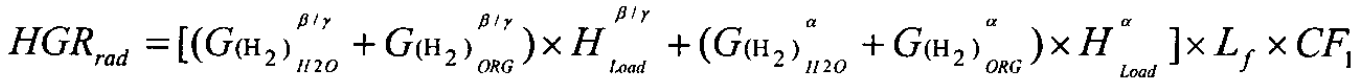

$$
\begin{aligned}
& H G R_{\text {corr }}=R_{\text {corr }} \times E_{H_{2}} \times A_{\text {wetted }} / M_{\text {tank }} \times C F_{2}
\end{aligned}
$$

with:

$$
\begin{aligned}
& G_{\left(\mathrm{H}_{2}\right)_{O R G}{ }^{\beta / \gamma}}=a_{r a d} \times \exp ^{\left(-E_{r a d} / R T\right)} \times\left(r_{f} \times[T O C]\right) \\
& G_{\left(\mathrm{H}_{2}\right)^{\beta / \gamma}{ }^{\beta / \gamma}}=\frac{0.32}{1+2.4\left[\mathrm{NO}_{3}^{-}\right]+0.62\left[\mathrm{NO}_{2}^{-}\right]+0.31\left[\mathrm{Na}^{+}{ }_{\text {eex }}^{2}\right.}+\frac{0.13}{1+139\left[\mathrm{NO}_{3}^{-}\right]+54\left[\mathrm{NO}_{2}^{-}\right]}
\end{aligned}
$$

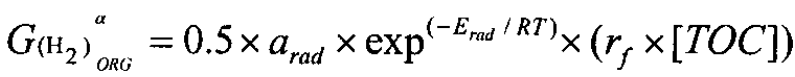

$$
\begin{aligned}
& G_{\left(\mathrm{H}_{2}\right)^{\alpha}{ }^{\alpha}{ }_{2 O}}=\frac{1.05}{1+2.4\left[\mathrm{NO}_{3}^{-}\right]+0.63\left[\mathrm{NO}_{2}^{-}\right]}+\frac{0.35}{1+3900\left[\mathrm{NO}_{3}^{-}\right]+1400\left[\mathrm{NO}_{2}^{-}\right]}
\end{aligned}
$$

and:

$$
\begin{array}{rl}
\mathrm{E}_{\mathrm{thm}}= & 89.6 \mathrm{~kJ} / \text { mole, the activation energy for the thermal reaction } \\
\mathrm{a}_{\text {thm }}= & 3.94 \mathrm{E}+09 \text { mole } / \mathrm{kg} \text {-day, pre-exponential factor of the thermal rate } \\
\mathrm{E}_{\mathrm{rad}}= & 48.8 \mathrm{~kJ} / \text { mole, activation energy in organic radiolysis, } \mathrm{G} \\
\mathrm{a}_{\mathrm{rad}}= & 1.11 \mathrm{E}+07 \mathrm{H}_{2} / 100 \mathrm{eV} \text {, the pre-exponential term in organic radiolysis, } \mathrm{G} \\
\mathrm{r}_{\mathrm{f}}= & 0.6 \text { for DSTs and } 0.3 \text { for SSTs (unitless), the TOC reactivity coefficient } \\
& \text { Note: The } \mathrm{r}_{\mathrm{f}}=0.3 \text { for SSTs is an average value from the tanks tested. If } \\
& \text { the tank has a high fraction of energetic organic compounds, the } \mathrm{r}_{\mathrm{f}} \text { can be } \\
& \text { adjusted to as high as } 0.6 . \\
= & 8.314 \mathrm{~J} / \text { mole } / \mathrm{K} \text {, gas constant } \\
\mathrm{R} & 6.0 \mathrm{E}-08 \text { for DSTs and } 2.4 \mathrm{E}-07 \text { for SSTs }\left(\mathrm{ft}^{3} / \mathrm{min} / \mathrm{ft}^{2}\right) \text {, corrosion } \\
\mathrm{R}_{\text {corr }}= & \text { coefficient } \\
\mathrm{E}_{\mathrm{H} 2}= & \text { the hydrogen generation efficiency coefficient from corrosion is } 20 \% \text { if } \\
& {\left[\mathrm{NO}_{3}^{-}\right],\left[\mathrm{NO}_{2}^{-}\right], \text {and }\left[\mathrm{OH}^{-}\right]>0.1 \text {, otherwise it is } 50 \% .}
\end{array}
$$




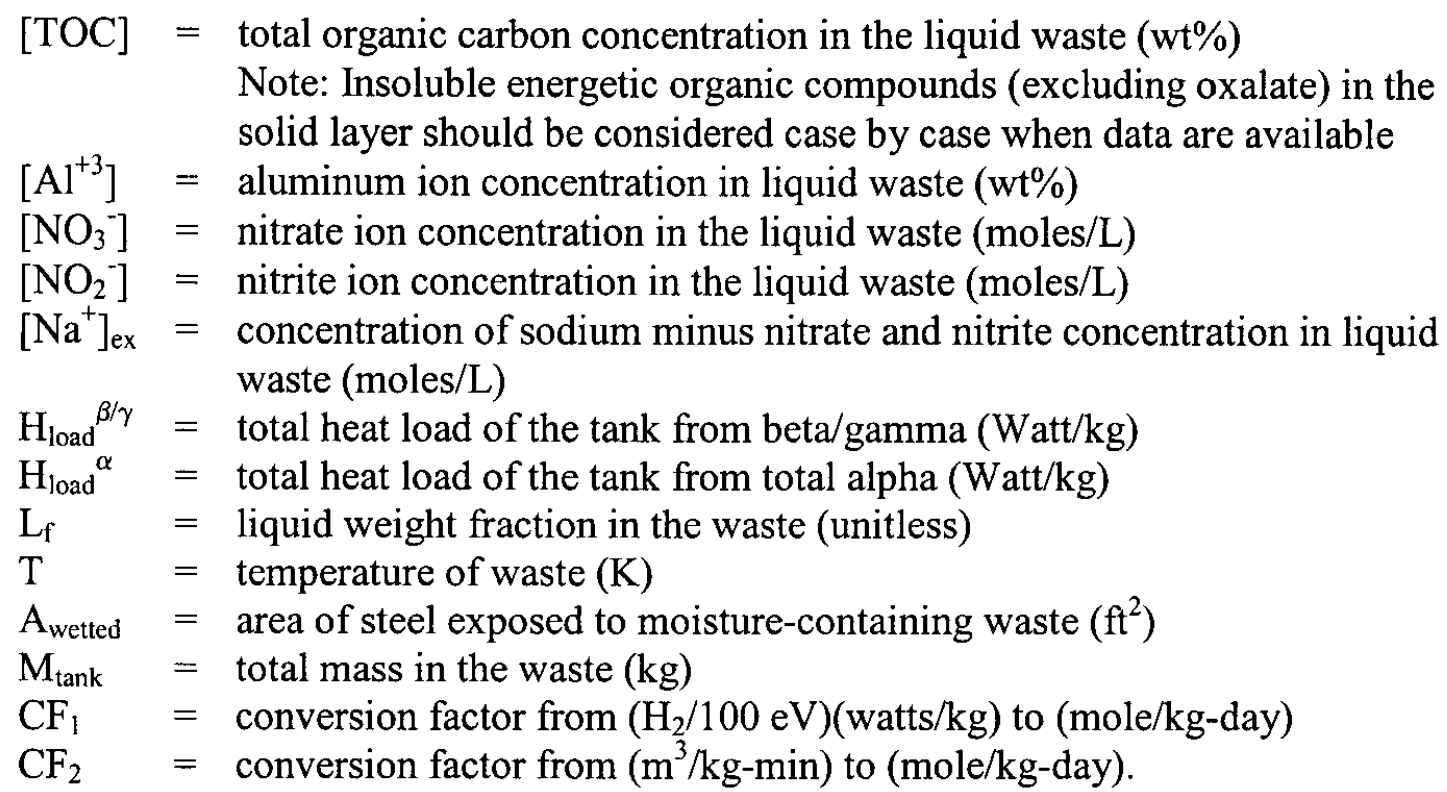

\subsection{EQUILIBRIUM GAS TRANSPORT RATE}

For a highly soluble gas, such as ammonia, the gas release rate from liquid waste is not a constant, but depends on the material transport properties and the ammonia concentration gradient between the liquid and vapor phases and appropriate Henry's Law constants. The Henry's Law constant is a function of temperature in pure water. In mixed salt solutions, Henry's Law constants are functions of both temperature and the concentrations of the ions in the solution. For a closed system, the Henry's Law in a mixed solution describes the relationship of a soluble gas in the liquid and vapor phases as provided in Equation 6-2:

$$
C_{l}=K_{H} \cdot P_{g}
$$

With $K_{H}=K_{H}{ }^{o} \cdot 10^{-\sum_{i}\left(h_{i}+h_{g}\right) \cdot C_{i}}$

and

$$
K_{H}{ }^{o}=e^{-8.0964+3917.5 / \mathrm{T}-0.00314 \mathrm{~T}}
$$

where:

$$
\begin{aligned}
& \mathrm{C}_{\mathrm{l}}=\text { ammonia concentration in the liquid phase }\left(\mathrm{kg}-\mathrm{mole} / \mathrm{m}^{3}\right) \\
& \mathrm{K}_{\mathrm{H}}=\text { Henry's Law constant }\left(\mathrm{kg}-\mathrm{mole} / \mathrm{m}^{3}-\mathrm{atm}\right) \\
& \mathrm{P}_{\mathrm{g}}=\text { partial pressure of the ammonia }(\mathrm{atm}) \\
& \mathrm{K}_{\mathrm{H}} \circ=\text { Henry's Law constant in the pure water }\left(\mathrm{kg}-\mathrm{mole} / \mathrm{m}^{3}-\mathrm{atm}\right) \\
& \mathrm{h}_{\mathrm{i}}=\text { Ionic dependent coefficient } \\
& \mathrm{h}_{\mathrm{g}}=\text { gas specific constant for ammonia }
\end{aligned}
$$


$\mathrm{C}_{\mathrm{i}} \quad=$ ion concentration in the solution.

$\mathrm{T}=$ temperature of waste $(\mathrm{K})$

This modified equation to calculate Henry's Law constant in a mixed solution is documented in "The Estimation of Gas Solubility in Salt Solutions at Temperature from $273 \mathrm{~K}$ to $363 \mathrm{~K}$," AICHE Journal (Weisenberger and Schumpe 1996). However, the Weisenberger and Schumpe (1996) formula is good only for the solution up to $5 \underline{\mathrm{M}}$. RPP-4941, Methodology for Predicting Flammable Gas Mixtures in Double-Contained Receiver Tanks, reported Henry's Law constants for DST 241-SY-101 simulant waste at different dilution conditions and temperatures. This study covers solution concentrations ranging from 5 to $21 \underline{\mathrm{M}}$ at temperatures of $20^{\circ} \mathrm{C}$ to $70^{\circ} \mathrm{C}$.

Consider the two-film theory of mass transfer. The ammonia release will encounter the resistance from two films, the liquid film and the gas film, between the bulk liquid and bulk vapor phases. The release rate is proportional to the difference between the ammonia liquid concentration and the ammonia vapor concentration before reaching equilibrium. It also is proportional to the mass transport coefficient, $h$, and the effective area, A. Therefore, the release rate can be derived as provided in Equation 6-3:

$$
R_{g}=h \cdot A \cdot\left(C_{l}-K_{H} \cdot P \cdot v \cdot C_{g}\right)
$$

where:

$$
\begin{array}{ll}
R_{g} & =\text { gas release rate }(\mathrm{kg}-\text { mole/day) } \\
h & =\text { overall mass transport coefficient from liquid to vapor }(\mathrm{m} / \text { day }) \\
\mathrm{A} & =\text { effective area for the transport }\left(\mathrm{m}^{2}\right) \\
\mathrm{C}_{1} & =\text { current ammonia concentration in liquid }\left(\mathrm{kg}-\mathrm{mole} / \mathrm{m}^{3}\right) \\
\mathrm{P} & =\text { dome space total pressure }(\mathrm{atm}) \\
\nu & =\text { specific molar volume of gas in the dome space }\left(\mathrm{m}^{3} / \mathrm{kg}-\mathrm{mole}\right) \\
\mathrm{C}_{\mathrm{g}} & =\text { current ammonia concentration in the dome space }\left(\mathrm{kg}-\mathrm{mole} / \mathrm{m}^{3}\right) \\
\mathrm{K}_{\mathrm{H}} & =\text { Henry's Law constant }\left(\mathrm{kg}-\mathrm{mole} / \mathrm{m}^{3}-\mathrm{atm}\right)
\end{array}
$$

As Equation 6-3 shows, the ammonia gas release rate clearly is a function of the ammonia concentrations in the liquid and vapor phases and the Henry's Law constant for ammonia in the solution. In the two-film-theory of mass transfer, the overall mass transport coefficient, $h$, contains the transport coefficient $h_{1}$ for liquid diffusing through the liquid film and $h_{g}$ for the gas diffusing through the gas film. Equations of the calculated h are described in detail in RPP-4941.

\subsection{TIME-DEPENDENT GAS CONCENTRATION MODEL}

A time-dependent gas concentration model for the tank dome space was developed and is documented in RPP-5926. The model calculates the gas concentrations for hydrogen, ammonia, and methane at a given time under a given ventilation condition. Hydrogen, the major flammable gas, along with ammonia and methane, are observed in the tank farms. Hydrogen is insoluble and observed mostly in the tank dome space. In the model, the gas release rates of hydrogen are calculated with the HGR model (HNF-3851) as summarized in a previous section. 
Ammonia is very soluble and found mainly in the liquid waste. In the model, the gas transport of ammonia is handled with the equilibrium model of mass transport. In addition, in the model, the gas release rates of methane and nitrous oxide (as oxidizer observed in the mixture) are derived from the steady-state concentration and ventilation rate in the tank dome space.

In order to model the flammability parametrically in terms of waste fraction, it is convenient to convert the time gas concentration model from the volume-based to waste-filled fraction system, as documented in RPP-8050 and summarized as follows. In brief, the waste volume can be expressed in terms of the waste-filled fraction, $f$, of the total tank volume, $V$, as $f V$, and the tank dome space volume is expressed as, (l-f) $V$, as shown in Figure 6-1.

Figure 6-1. The Model of Waste Volume Fraction.

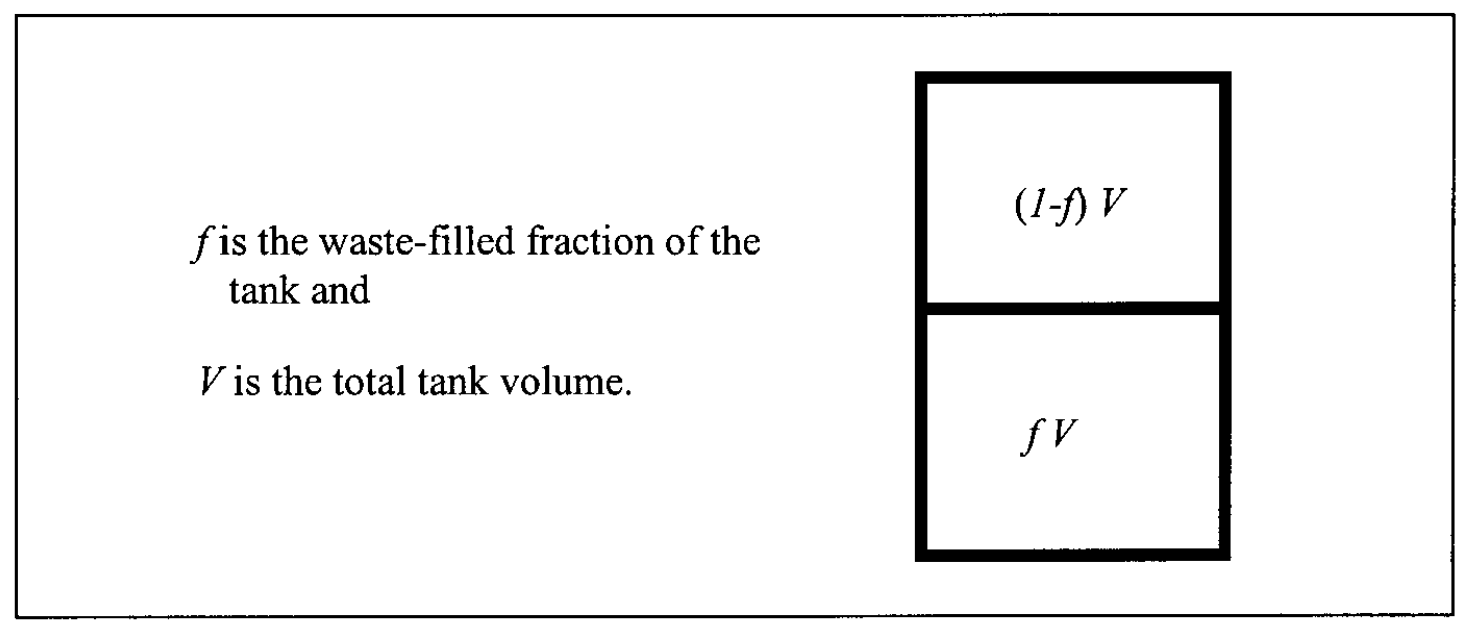

For the insoluble flammable gases, by solving the differential equation of the mass balance in the tank headspace, a time-dependent gas concentration at time $t$ in terms of waste-filled fraction, $f$, $\left[C_{g}\right](t)$, in the units of volume percent is given as Equation 6-4:

$$
\left[C_{g}\right](t)=\left[C_{g}\right]\left(t_{0}\right) \exp (-b \cdot t)+\left[\frac{f}{b \cdot(1-f)}\right] U_{g}[1-\exp (-b \cdot t)]
$$

Where:

$$
\begin{aligned}
& \begin{array}{lll}
f & = & \text { waste-filled fraction (unitless) } \\
b & = & \text { ventilation rate constant of } 0.45 \% \text { per day for barometric breathing }
\end{array} \\
& \text { or the decay parameter from venting in general which is the ratio of } \\
& \text { vent rate and headspace volume (1/day) } \\
& {\left[C_{g}\right]\left(t_{o}\right)=\text { initial gas concentration at time } \mathrm{t}_{\mathrm{o}}\left(\mathrm{kg}-\mathrm{mole} / \mathrm{m}^{3}\right)} \\
& t=\text { time (days) } \\
& U_{g} \quad=\quad \text { unit gas release rate per unit waste volume }\left(\mathrm{kg}-\mathrm{mole} / \mathrm{m}^{3} \text {-day }\right)
\end{aligned}
$$


For steady state, the first term of Equation 6-4 drops to zero, and the factor of [1- $\left.e^{(-b t)}\right]$ becomes 1, and the gas concentration becomes Equation 6-5:

$$
\left[C_{g}\right]_{s s}=\left[\frac{f \cdot U_{g}}{b \cdot(1-f)}\right] \times 100 \%
$$

Under zero ventilation, Equation 6-4 becomes the following:

$$
\left[C_{g}\right]_{\%}(t)=\left[C_{g}\right]_{\%}\left(t_{0}\right)+\left[\frac{f}{(1-f)} \cdot U_{g} \cdot t\right] \%
$$

For soluble flammable gas, the time-dependent gas concentration is given as Equation 6-7:

$$
\left[C_{g}\right](t)=\left[C_{g}\right]\left(t_{0}\right) \exp \left(-k_{1} \cdot t\right)+\left[\frac{k_{2}}{k_{1}}\right]\left[1-\exp \left(-k_{1} \cdot t\right)\right]
$$

with

$$
k_{1}=\left[b \cdot(1-f)+h \cdot R_{s v} \cdot f \cdot K_{H} \cdot P \cdot v\right] /(1-f)
$$

and

$$
k_{2}=\left[h \cdot R_{s v} \cdot f \cdot C_{l}\right] /(1-f)
$$

where:

$$
\begin{aligned}
h & =\text { overall mass transport coefficient from liquid to vapor }(\mathrm{m} / \text { day }) \\
f & =\text { waste-fill fraction } \\
R_{s v} & =\text { ratio of surface area and waste volume } \\
C_{l} & =\text { ammonia concentration in liquid }\left(\mathrm{kg}-\mathrm{mole} / \mathrm{m}^{3}\right) \\
C_{g} & =\text { ammonia concentration in a tank dome space }\left(\mathrm{kg}-\mathrm{mole} / \mathrm{m}^{3}\right) \\
P & =\text { tank dome space total pressure }(\mathrm{atm}) \\
v & =\text { specific molar volume of gas in the tank dome space }\left(\mathrm{m}^{3} / \mathrm{kg}\right. \text {-mole) } \\
K_{H} & =\text { Henry's Law constant }\left(\mathrm{kg}-\mathrm{mole} / \mathrm{m}^{3}-\mathrm{atm}\right) .
\end{aligned}
$$

The steady-state gas concentration becomes Equation 6-8 for soluble components:

$$
\left[C_{g}\right]_{s s}=\left[\frac{h \cdot R_{s v} \cdot f \cdot C_{l}}{b \cdot(1-f)+h \cdot R_{s v} \cdot f \cdot K_{H} \cdot P \cdot v}\right]
$$


Under zero ventilation, Equation 6-9 is the soluble component equivalent to Equation 6-7:

$$
\begin{aligned}
& {\left[C_{g}\right](t)=\left[C_{g}\right]\left(t_{0}\right) \exp \left(-g_{1} \cdot t\right)+\left[\frac{g_{2}}{g_{1}}\right]\left[1-\exp \left(-g_{1} \cdot t\right)\right]} \\
& \text { with } \\
& \qquad g_{1}=\frac{f}{(1-f)} \cdot\left[h \cdot R_{s v} \cdot K_{H} \cdot P \cdot v\right] \\
& \text { and } \\
& \qquad g_{2}=\frac{f}{(1-f)} \cdot\left[h \cdot R_{s v} \cdot C_{l}\right]
\end{aligned}
$$

In some cases, particularly when the product of $h$ and A is large, the $g_{l} t$ is much greater than one within a few days. So the decay rate $\exp \left(-g_{I} . t\right)$ goes to zero in a few days, thus the vapor concentration is simply the vapor equilibrium concentration $C_{e q}$ with liquid phase as shown in Equation 6-10:

$$
C_{e q}=\frac{C_{l}}{K_{H} \cdot P \cdot v}
$$

\subsection{FLAMMABILITY LEVEL MODEL CALCULATION}

Using the time-dependent gas concentration (Equation 6-4 for insoluble gas or Equation 6-7 for soluble gas) and the Le Chatelier's rule a time-dependent percentage of LFL, $L F L_{m}(t)$, of the mixture can be calculated as shown in Equation 6-11:

$$
L F L_{n}(t)=\left[\frac{\left[\mathrm{H}_{2}\right](t)}{\left[\mathrm{H}_{2}\right]_{L F L}}+\frac{\left[\mathrm{CH}_{4}\right](t)}{\left[\mathrm{CH}_{4}\right]_{L F L}}+\frac{\left[\mathrm{NH}_{3}\right](t)}{\left[\mathrm{NH}_{3}\right]_{L F L}}\right] \times 100 \%
$$

where:

$$
\begin{aligned}
& {\left[\mathrm{H}_{2}\right](t)=\text { hydrogen concentration (volume percent) in tank dome space at time } \mathrm{t}} \\
& {\left[\mathrm{NH}_{3}\right](\mathrm{t})=\text { ammonia concentration (volume percent) in tank dome space at time } \mathrm{t}} \\
& {\left[\mathrm{CH}_{4}\right](\mathrm{t})=\text { methane concentration (volume percent) in tank dome space at time } \mathrm{t}} \\
& \mathrm{LFL} \mathrm{L}_{m}(\mathrm{t})=\text { percentage of LFL for the mixture of the flammable gases at time } \mathrm{t} \\
& {\left[\mathrm{H}_{2}\right]_{L F L}=\text { volume percent of hydrogen at its LFL in air alone }} \\
& {\left[\mathrm{NH}_{3}\right]_{L F L}=\text { volume percent of ammonia at its LFL in air alone }} \\
& {\left[\mathrm{CH}_{4}\right]_{L F L}=\text { volume percent of methane at its LFL in air alone. }}
\end{aligned}
$$

The volume percents of the LFLs $\left(\left[\mathrm{H}_{2}\right]_{L F L}=4 \%,\left[\mathrm{NH}_{3}\right]_{L F L}=15 \%\right.$, and $\left.\left[\mathrm{CH}_{4}\right]_{L F L}=5 \%\right)$ have been established for a fuel-air mixture. 


\section{RPP-CALC-29700 REV 1}

For a given ventilation rate, the time to reach a specified gas concentration under given ventilation conditions can be obtained by rewriting Equation 6-4 and is given as Equation 6-12:

$$
t=\frac{\ln \left\{\frac{f \cdot U_{g}-b \cdot(1-f) \cdot C_{g}\left(t_{0}\right)}{f \cdot U_{g}-b \cdot(1-f) \cdot C_{g}(t)}\right\}}{b}
$$

Similarly, for soluble gases, the time to reach a specified gas concentration under a given ventilation condition can be obtained by rewriting Equation 6-7 and is given as Equation 6-13:

$$
t=\frac{\ln \left\{\frac{k_{2}-k_{1} \cdot C_{g}\left(t_{0}\right)}{k_{2}-k_{1} \cdot C_{g}(t)}\right\}}{k_{1}}
$$

$$
\begin{aligned}
& \text { with } \quad k_{1}=\left[b \cdot(1-f)+h \cdot R_{s v} \cdot f \cdot K_{l l} \cdot P \cdot v\right] /(1-f) \\
& \text { and } \quad k_{2}=\left[h \cdot R_{s v} \cdot f \cdot C_{l}\right] /(1-f)
\end{aligned}
$$

However, the time to reach a specified flammability limit of the mixture was not calculated explicitly. A customized macro function in Excel ${ }^{1}$ using Visual Basic Application ${ }^{2}$, based on Equation 6-12 for an insoluble gas and Equation 6-13 for a soluble gas, was developed to calculate the time to reach a specific flammability level. For zero ventilation condition, the time to $25 \%$ and $100 \%$ of the LFL is simply the accumulative time to the specified flammability level, which is straightforward.

It is worthwhile to determine the minimum ventilation rate required to maintain the tank dome space below $100 \%$ LFL. A steady-state flammability level can be expressed as shown in Equation 6-14:

$$
L F L_{s s}=\left[\frac{\left[\mathrm{H}_{2}\right]_{s s}}{\left[\mathrm{H}_{2}\right]_{L F L}}+\frac{\left[\mathrm{NH}_{3}\right]_{s s}}{\left[\mathrm{NH}_{3}\right]_{L F L}}+\frac{\left[\mathrm{CH}_{4}\right]_{s s}}{\left[\mathrm{CH}_{4}\right]_{L F L}}\right] \times 100 \%
$$

where:

$$
\begin{aligned}
L F L_{s s} & =\begin{array}{l}
\text { steady-state percentage of the LFL for the mixture of the flammable } \\
\\
\text { gases in the tank headspace }
\end{array} \\
{\left[\mathrm{H}_{2}\right]_{\mathrm{ss}}=} & \text { steady-state hydrogen concentration (volume percent) } \\
{\left[\mathrm{NH}_{3}\right]_{\mathrm{ss}}=} & \text { steady-state ammonia concentration (volume percent) } \\
{\left[\mathrm{CH}_{4}\right]_{\mathrm{ss}}=} & \text { steady-state methane concentration (volume percent) }
\end{aligned}
$$

\footnotetext{
${ }^{1}$ Excel is a registered trademark of Microsoft Corporation, Redmond, Washington.

${ }^{2}$ Visual Basic is a registered trademark of Microsoft Corporation, Redmond, Washington.
} 


\section{RPP-CALC-29700 REV 1}

The steady-state concentration can be calculated using Equations 6-5 and 6-8 for the insoluble gases, $\mathrm{H}_{2}$ and $\mathrm{CH}_{4}$, and the soluble gas, $\mathrm{NH}_{3}$, respectively. These steady-state gas concentrations are ventilation-rate dependent. The minimum ventilation rate to maintain the flammability under $100 \%$ LFL can be calculated using Equation 6-14 by setting the steady-state concentration at a specified percentage of the LFL (e.g., 100\%). Again, the ventilation rate is embedded in the equation, and a customized macro function in Excel using Visual Basic code was developed to calculate the minimum ventilation to reach the specified flammability level.

\subsection{FLAMMABILITY ANALYSIS FOR THE PROCESS UNDER LOW VACUUM}

Under the normal evaporation process, the water vapor along with flammable gases such as hydrogen, methane, and ammonia are generated from the liquid waste in the vessel C-A- 1 into the headspace, and continuously removed by the low vacuum condition through the gaseous effluent pathway to vessel vent exit. This analysis simply considers the mass balance of the vapor components in the vapor flow at various stages using the flow rates of each input stream. Once the rates of all vapor components are estimated in the flow, the flammability of the vapor mixture can be calculated.

For hydrogen and methane, during normal operation, the highest generation rate occurs when the evaporation process reaches the steady-state slurry production mode, i.e., when the waste is concentrated at the targeted SpG (1.4-1.6). This is evident since a plot of the time to LFL against $\mathrm{SpG}$ is linear with a negative slope (Figure 8-1). The gas generation rate in moles per minute can be calculated for given waste conditions (e.g., the concentration of chemicals and radionuclide, the waste temperature, wt\% water at the targeted slurry $\mathrm{SpG}$ ) using the rate equation model given in Section 6.2. The method to evaluate a waste condition at a targeted slurry SpG is given in Section 4.1 .

The ammonia is soluble and its transport mechanism or release rate is governed by thermodynamic equilibrium between the liquid and vapor phase and the mass transfer discussed in Section 6.2. The equilibrium model of ammonia transport described in Section 6.3 is not validated for the system under the vacuum condition. The approach here is to obtain the ammonia release mass rate (moles per minute) to the headspace by calculating the difference of mass rate between the feed and slurry steams as follows (Equation 6-15).

$$
M_{N H 3}^{\text {headspace }}=\left(R_{\text {feed }} \times C_{\text {feed }}^{N H 3}\right)-\left(R_{\text {slurry }} \times C_{\text {slurry }}^{N H 3}\right)
$$

where:

$\begin{aligned} M_{N H 3}^{\text {headspace }} & \text { mass flow of ammonia in the headspace } \\ R_{\text {feed }} & =\text { flow rate of feed stream } \\ C_{\text {feed }}^{N H 3} & =\text { ammonia concentration in feed stream } \\ R_{\text {slurry }} & =\text { flow rate of slurry stream } \\ C_{\text {slurry }}^{N H 3} & =\text { ammonia concentration in slurry stream. }\end{aligned}$




\section{RPP-CALC-29700 REV 1}

The slurry ammonia concentration uses conservatively $10 \%$ of the feed ammonia concentration based on the sample results (see Section 5.0). The flow rate of each steam used in this calculation is from the high side of the possible rates as given in Table 2-2 of HNF-14755. The water mass rate into the headspace can be calculated as follows (Equation 6-16):

$$
M_{\text {H2O }}^{\text {headspace }}=\left\{\left(R_{\text {feed }} \times D_{\text {feed }} \times W t \%_{H 20}^{\text {feed }}\right)-\left(R_{\text {slurry }} \times D_{\text {slurry }} \times W \%_{H 2 O}^{\text {slury }}\right)\right\} / 18
$$

where:

$$
\begin{aligned}
M_{H 2 O}^{\text {headspace }} & =\text { mass flow of water in the headspace } \\
D_{\text {feed }} & =\text { density of feed stream } \\
C_{\text {feed }}^{N H 3} & =\text { ammonia concentration in feed stream } \\
D_{\text {slurry }} & =\text { density of slurry stream } \\
C_{\text {slury }}^{N H 3} & =\text { ammonia concentration in slurry stream } \\
W t \%_{\text {H2o }}^{\text {fed }} & =\text { weight fraction of water in the feed stream } \\
W t_{H 20}^{\text {shurry }} & =\text { weight fraction of water in the slurry stream. }
\end{aligned}
$$

In the headspace of C-A-1, there is no flammable gas concern because the mixture is mainly water vapor (over $99 \%$ ) and very little air. Similar conditions apply to the 42 -in. pipeline between the C-A-1 and the primary condenser itself. When the vapor gases enter the primary condenser (E-C-1), the majority of water and soluble gas (e.g., ammonia) undergoes condensation and goes to the condensate tank TK-C-100. Only insoluble gases (e.g., hydrogen and methane) of the flammable gas concerned plus a small fraction of water and ammonia remains in the vapor phase after the primary condenser. Figure 6-2 is the diagram of the steam jet ejector and three stages of condensers. 


\section{RPP-CALC-29700 REV 1}

Figure 6-2. Steam Jet Ejector and Three Stages of Condensers

(taken from HNF-14755).

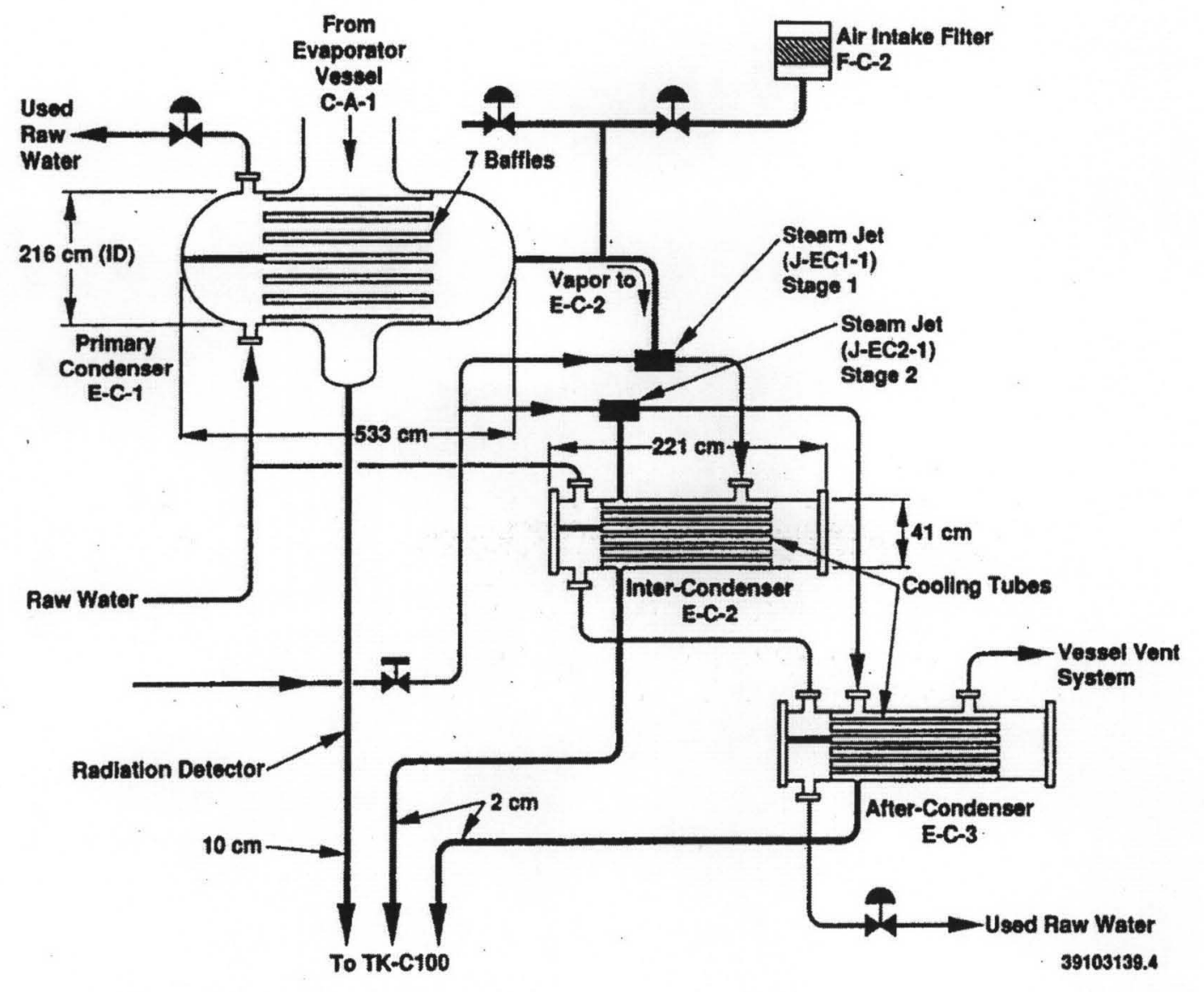

As mentioned in Section 3.0, in-leakage air (with filter F-C-2) merges in with the exit effluent gaseous line of primary condenser to adjust the pressure of vacuum system (see Figure 6-2). There is a concern about the flammable gas issue because the air was introduced into the gaseous effluent along with remaining ammonia plus insoluble hydrogen and methane from the original vapor steam after the primary condenser. The in-leakage air mass rate $\mathrm{M}_{\text {air }}{ }^{\text {effluent }}$ (g-mole/min) into the gaseous effluent after the primary condenser can be easily calculated as follows (Equation 6-17):

$$
M_{\text {air }}^{\text {efflunt }}=\left(R_{\text {in-leakage }} /\left(22.4 \times T_{\text {ambient }} / 273\right)\right.
$$

It is assumed that the mass flow rate of hydrogen and methane after primary condenser is the same as in the headspace. For the calculations, it is also assumed the percent of ammonia remaining in the vapor phase after primary condenser is $8.6 \%$ (see Section 5.0 ) of the ammonia mass rate $\mathrm{M}_{\mathrm{NH} 3}$ headspace (mole/min) in the headspace and given as follows (Equation 6-18): 


$$
M_{N H 3}^{\text {effluent }}=8.6 \% \times M_{N H 3}^{\text {headspace }}
$$

The ammonia survival ratio is $8.6 \%$ right after the primary condenser, and it drops another $40 \%$ of the $8.6 \%$ after the inter-condenser (HNF-14755, Appendix 2B, Table 2B-1, Stream 6 and 8). The percent of water remaining in the vapor phase after primary condenser is $0.02 \%$ (HNF-14755, Appendix 2B, Table 2B-1, Stream 4 and 6) of the water mass rate $\mathrm{M}_{\mathrm{H} 2 \mathrm{O}}$ headspace $(\mathrm{mole} / \mathrm{min})$ in the headspace and given as follows (Equation 6-19):

$$
M_{H 2 O}^{\text {effluent }}=0.02 \% \times M_{H 2 O}^{\text {headspace }}
$$

At the same temperature and pressure, the volume percent concentration of each vapor gas per minute is the same as the g-mole percent concentration and can be calculated as follows (Equation 6-20):

$$
[\text { FlamGas }]_{(\text {vol\%) }}=\left[\frac{M_{i=A i r, H 2, C H 4, N H 3}^{\text {effuent }}}{\sum_{\text {FlamGas }}^{\text {efluent }}}\right] \times 100 \%
$$

The flammability of gaseous effluent pathway after the primary condenser can be calculated as follows (Equation 6-21):

$$
L F L_{m}=\left[\frac{\left[\mathrm{H}_{2}\right]_{\text {vol\% }}}{\left[\mathrm{H}_{2}\right]_{L F L}}+\frac{\left[\mathrm{NH}_{3}\right]_{\text {vol\% }}}{\left[\mathrm{NH}_{3}\right]_{L F L}}+\frac{\left[\mathrm{CH}_{4}\right]_{\text {vol } \%}}{\left[\mathrm{CH}_{4}\right]_{L F L}}\right] \times 100 \%
$$

where:

$$
\begin{aligned}
& {\left[\mathrm{H}_{2}\right]=\text { hydrogen concentration (volume percent) in gaseous effluent }} \\
& {\left[\mathrm{NH}_{3}\right]=\text { ammonia concentration (volume percent) in gaseous effluent }} \\
& {\left[\mathrm{CH}_{4}\right]=\text { methane concentration (volume percent) in gaseous effluent }} \\
& L F L_{m}=\text { percentage of } \mathrm{LFL} \text { for the mixture of the flammable gases } \\
& L F L_{H 2}=\text { volume percent of hydrogen at its } \mathrm{LFL} \text { in air alone } \\
& L F L_{N H 3}=\text { volume percent of ammonia at its } \mathrm{LFL} \text { in air alone } \\
& L F L_{C H 4}=\text { volume percent of methane at its LFL in air alone. }
\end{aligned}
$$

The volume percents of the LFLs $\left(\left[\mathrm{H}_{2}\right]_{L F L}=4 \%,\left[\mathrm{NH}_{3}\right]_{L F L}=15 \%\right.$, and $\left.\left[\mathrm{CH}_{4}\right]_{L F L}=5 \%\right)$ have been established for a fuel-air mixture. It is assumed that the same LFL for each gas applies at the high vacuum condition. 


\subsection{USE OF COMPUTER SOFTWARE}

This case study uses a validated Excel spreadsheet, documented in RPP-5926 and RPP-8050, to calculate the HGRs, the time to $25 \%$ and $100 \%$ of the LFL, and the minimum ventilation rate. The spreadsheet was verified in compliance with TFC-ENG-CHEM-D-33, Spreadsheet Verification, and is documented in spreadsheet verification form SVF-032.

Spreadsheet owner: T. A. Hu

Spreadsheet name: RPP-5926-8050-R4-LFL-CAL-T2-122004.xls

Spreadsheet location: Hanford $\backslash$ Data $\backslash$ Sitedata $\backslash$ FlamGas $\backslash$ RPP-5926 Rev 4\Calculations

This spreadsheet uses the input data to calculate the gas generation rates, then calculates the flammability and time to LFL for a given ventilation rate.

A new Excel spreadsheet "RPP-CALC-29700 Rev 0 Calculations.xls" was created by copying the necessary worksheets from the master spreadsheet

RPP-5926-8050-R4-LFL-CAL-T2-122004.xls (above) to calculate the time to LFL for the 242-A Evaporator case study. This new spreadsheet was verified in compliance with TFC-ENG-DESIGN-C-32, Spreadsheet Development and Verification, and is documented in spreadsheet verification form SVF-1165.

Spreadsheet owner: T. A. Hu

Spreadsheet name: RPP-CALC-29700 Rev 0 Calculations.xls

Spreadsheet location: Hanford $\backslash$ Data $\backslash$ Sitedata $\backslash$ FlamGas $\backslash$ RPP-5926 Rev 5\Evaporator 242-A Final Document 
RPP-CALC-29700 REV 1

This page intentionally left blank. 


\subsection{RESULTS}

Model calculations on flammability level, time to reach $25 \%$ and $100 \%$ of the LFL, and minimum vent rate to keep below $25 \%$ and $100 \%$ of the LFL are performed on the evaporation process of the 242-A Evaporator using the current 28 DST liquid wastes under various temperature, $\mathrm{SpG}$, and ammonia conditions. The flammability analysis has also been performed on the blended waste mixture of tanks 241-AP-104 and 241-AW-102 in the evaporator campaigns 07-01 and 07-02, the shutdown mode and the start-up mode of the operations. In addition, the flammability evaluation of the usage of AFA in the waste feed, which will increase the TOC concentration and thus increase the gas generation rate, has been performed. The results are given in the following sections.

\subsection{FLAMMABILITY LEVEL ON C-A-1 UNDER AMBIENT PRESSURE}

The flammability analysis modeled the cases where the concentrated waste sits on the C-A-1 vessel at the target $\mathrm{SpG}$ and operating temperature condition while the headspace pressure is ambient pressure of $1 \mathrm{~atm}$ under either barometric breathing or no ventilation. The flammable gas generated from the waste accumulates in the headspace, thus the steady-state flammability under barometric breathing and time to reach $25 \%$ and $100 \%$ of the LFL can be calculated. As mentioned in Section 4.0, the flammability analysis on C-A-1 has included the headspace of C-A-1 plus the gaseous effluent pathway of 42-in. pipeline and the vapor pathway in the primary condenser. In the calculations, the waste-filled faction is 0.69 for the HGR calculations and is 0.62 for the flammability calculation to cover the extended headspace. The results for the following cases are given in Appendix B.

Case 1: $\quad$ Raw waste condition.

Cases 2-5 and 11: With SpG of 1.5 and $30 \%$ feed ammonia at temperature of 120 , $130,140,150$, and $155^{\circ} \mathrm{F}$.

Cases 9-10: $\quad$ With SpG of 1.55 and $30 \%$ feed ammonia at temperature of 150 and $155^{\circ} \mathrm{F}$.

Cases 8 and 12-13: With SpG of 1.6 and $30 \%$ feed ammonia at waste temperature of 150,155 and $160^{\circ} \mathrm{F}$.

Cases 14: $\quad$ With $\mathrm{SpG}$ of 1.7 , and $30 \%$ feed ammonia at waste temperature of $155^{\circ} \mathrm{F}$

Cases 6-7: $\quad$ With SpG of 1.5 and 1.6 , and $100 \%$ feed ammonia at waste temperature of $150^{\circ} \mathrm{F}$

The results tables in Appendix B list the required HGR, ammonia transport properties, steadystate flammability of ammonia, the time to reach $25 \%$ and $100 \%$ of the LFL under both barometric breathing and zero ventilation conditions, and the minimum vent rate to keep below 
$25 \%$ of the LFL. A summary on the time to reach $25 \%$ of the LFL for the top five tanks is given in Table 8-1.

Table 8-1. Time to $25 \%$ of the Lower Flammability Limit for the Top Five Tanks.

\begin{tabular}{|c|c|c|c|c|c|c|c|}
\hline \multicolumn{3}{|c|}{ Tanks } & 241-AN-102 & 241-AN-107 & 241-AP-103 & 241-AP-106 & 241-SY-103 \\
\hline Conditions & Cases & SpG & \multicolumn{4}{c|}{ Time to 25\% of the lower flammability limit (days) } \\
\hline \multirow{2}{*}{$\begin{array}{c}150^{\circ} \mathrm{F} \\
\text { and } 30 \%\end{array}$} & 5 & 1.50 & 1.7 & 3.3 & 4.1 & 4.8 & 4.7 \\
\cline { 2 - 8 } Feed $\mathrm{NH}_{3}$ & 10 & 1.55 & 1.5 & 2.9 & 3.6 & 4.3 & 4.0 \\
\cline { 2 - 9 } & 8 & 1.60 & 1.3 & 2.6 & 3.2 & 3.8 & 3.4 \\
\hline \multirow{3}{*}{$\begin{array}{c}155^{\circ} \mathrm{F} \\
\text { and } 30 \%\end{array}$} & 11 & 1.50 & 1.3 & 2.6 & 3.2 & 3.7 & 3.7 \\
\cline { 2 - 8 } Feed $\mathrm{NH}_{3}$ & 9 & 1.55 & 1.2 & 2.3 & 2.8 & 3.3 & 3.1 \\
\cline { 2 - 8 } & 12 & 1.60 & 1.0 & 2.0 & 2.5 & 2.9 & 2.6 \\
\hline
\end{tabular}

A sensitivity plot of Table $8-1$ is given in Figure $8-1$. It is plot of time to $25 \%$ of the LFL versus the SpG. Each line represents a tank at certain temperature with very similar slope. The bottom two lines are DST $241-\mathrm{AN}-102$ at 155 and $150^{\circ} \mathrm{F}$, respectively, which gives the shortest time to $25 \%$ of the LFL ranging 1.0 to 1.7 days. The next lowest line set is DST 241-AN-107 with tank DST 241-AP-103 at $155^{\circ} \mathrm{F}$ in between. The highest line set is for DST 241-AP-106 while DSTs 241-SY-103 and 241-AP-103 are in between. Note that for each set, the higher temperature is in the lower side which has shorter time to $25 \%$ of the LFL. DST $241-\mathrm{SY}-103$ has the largest slope at $150^{\circ} \mathrm{F}$, and it has nonlinear behavior at $155^{\circ} \mathrm{F}$. This is because the ammonia has a larger contribution to the total flammability while the linear behavior on $\mathrm{SpG}$ is the characteristic of hydrogen generation.

In addition, to support the analysis in HNF-SD-WM-FHA-024, Fire Hazards Analysis for the Evaporator Facility (242-A), an estimate of how much time it will take for the C-A-1 to reach $750 \%$ of the LFL (which is equivalent to 30 volume percent of hydrogen) is performed. Using the case 12 condition (temperature at $155^{\circ} \mathrm{F}$ and SpG of 1.6) with the tank waste of DST $241-\mathrm{AN}-102$, the time to reach $750 \%$ of the LFL is 31.9 days. 
Figure 8-1. Time to 25\% of the Lower Flammability Limit Versus Target Slurry SpG.

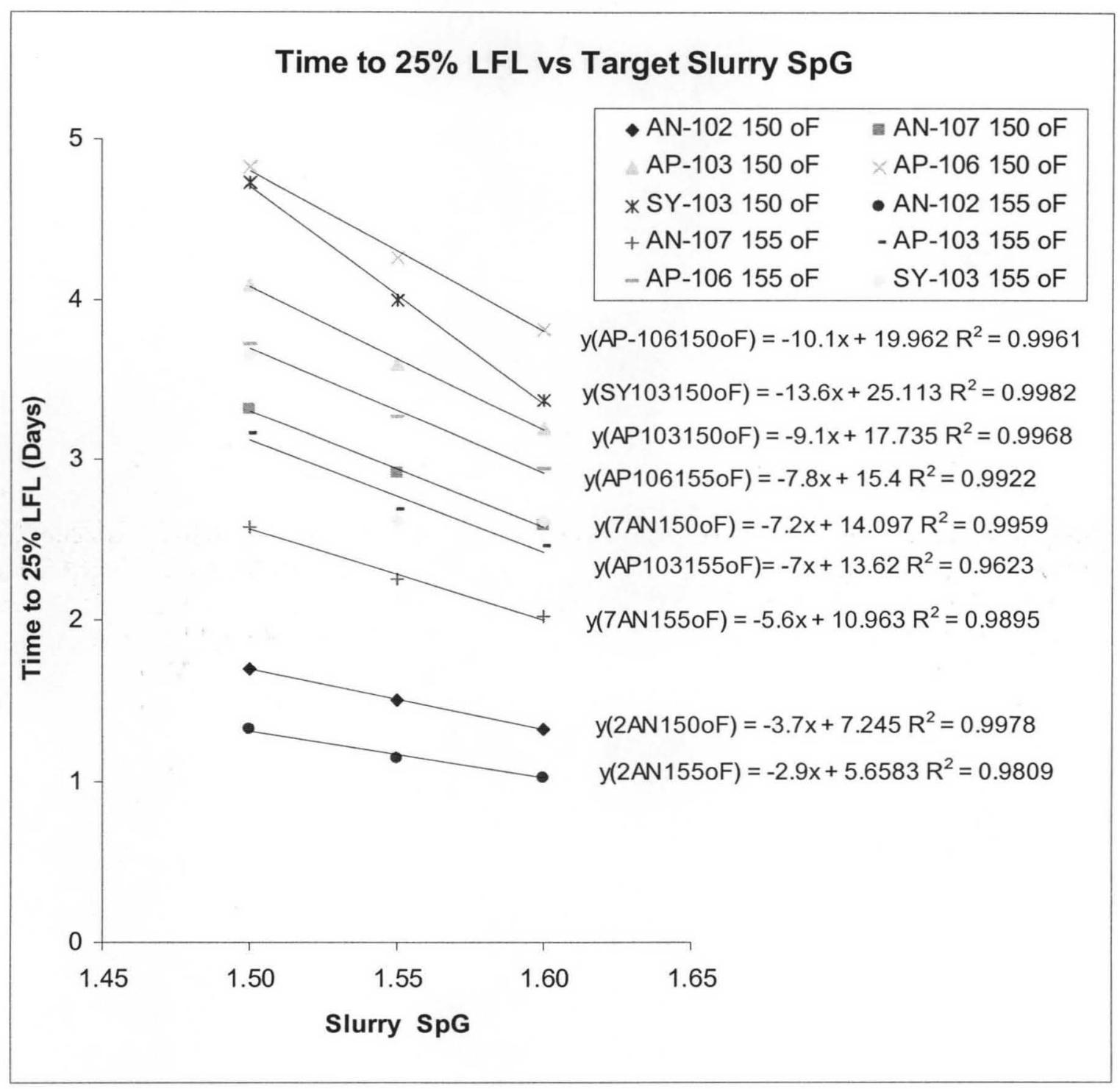

Table 8-2 summarizes the time to $25 \%$ of the LFL as function of temperature at SpG of 1.5 and $30 \%$ of the feed ammonia condition for the top five tanks. For each tank, apparently the higher the temperature, the shorter time to $25 \%$ of the LFL. Figure $8-2$ plots the behavior of time to $25 \%$ of the LFL as function of temperature. 
Table 8-2. Summary of Time to $25 \%$ of the Lower Flammability Limit as Function of Temperature.

\begin{tabular}{|c|c|c|c|c|c|c|c|}
\hline \multirow{2}{*}{$\begin{array}{c}\text { Waste } \\
\text { condition }\end{array}$} & \multirow{2}{*}{ Cases } & \multirow{2}{*}{$\begin{array}{c}\text { Temp } \\
\left({ }^{\circ} \mathbf{F}\right)\end{array}$} & \multicolumn{5}{|c|}{ Time to reach 25\% of the lower flammability limit (days) } \\
\cline { 4 - 8 } & & & $\mathbf{2 4 1 - A N - 1 0 2}$ & $\mathbf{2 4 1 - A N - 1 0 7}$ & 241-AP-103 & 241-AP-106 & 241-SY-103 \\
\hline \multirow{3}{*}{$\begin{array}{c}\text { SpG 1.5 } \\
\text { and 30\% }\end{array}$} & Case 2 & 120 & 8.4 & 14.9 & 21.0 & 24.1 & 23.9 \\
\cline { 2 - 8 } & Case 3 & 130 & 4.9 & 9.0 & 12.1 & 14.0 & 13.9 \\
\cline { 2 - 8 } $\mathrm{NH}_{3}$ left & Case 4 & 140 & 2.9 & 5.5 & 7.0 & 8.2 & 8.1 \\
\cline { 2 - 8 } & Case 5 & 150 & 1.7 & 3.3 & 4.1 & 4.8 & 4.7 \\
\hline
\end{tabular}

Figure $8-2$. Time to $25 \%$ of the Lower Flammability Limit Versus Temperature.

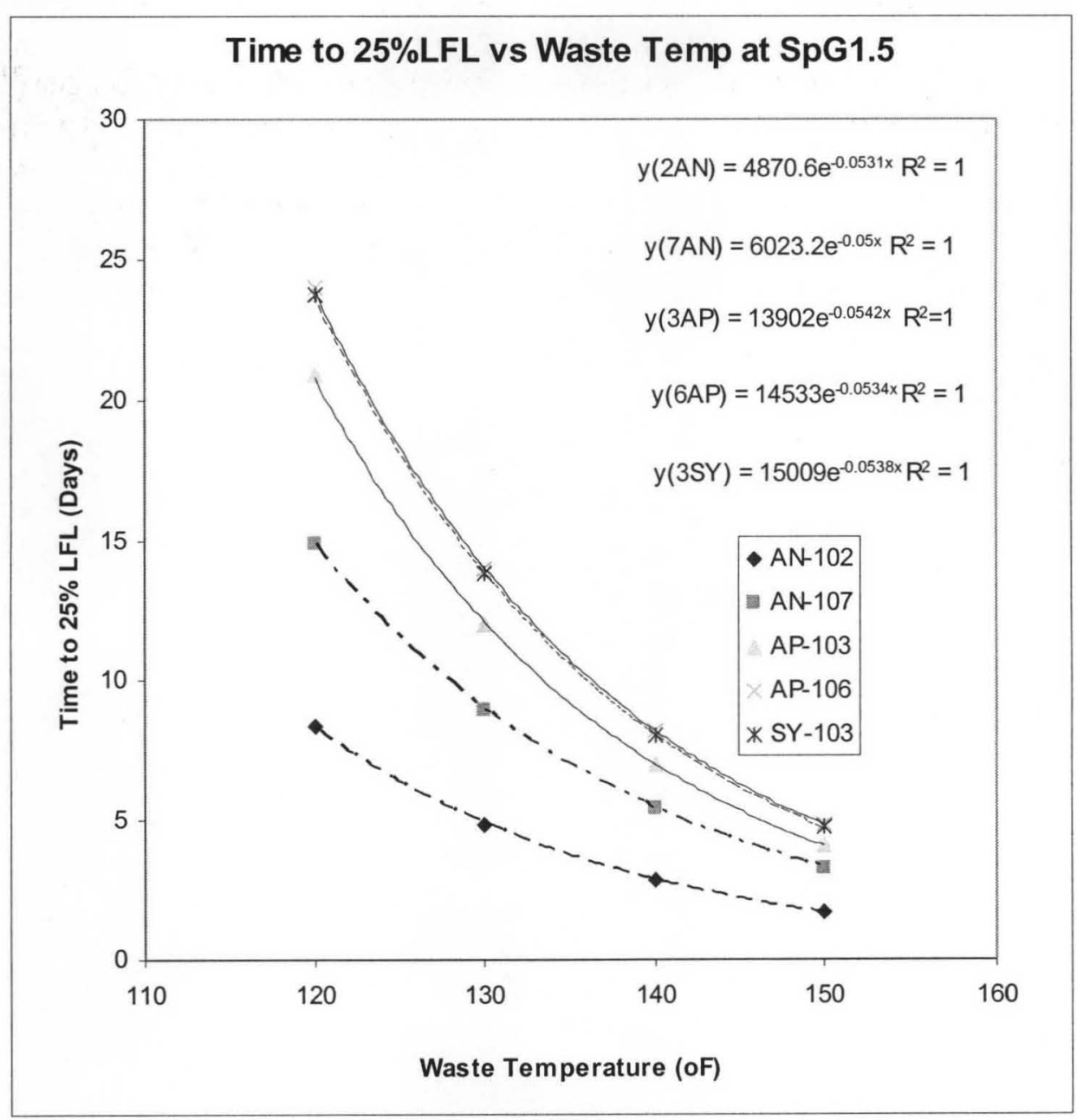

As shown in Figure 8-2, the time to $25 \%$ of the LFL decreases exponentially as function of temperature. It is because the HGR, and thus the flammability, is increased exponentially as function of temperature; therefore, the time to reach $25 \%$ of the LFL becomes shorter as the temperature increases. 


\section{RPP-CALC-29700 REV 1}

In addition to the above analyses using the 28 DSTs waste inventory as the available source waste spectrum, the flammability analyses performed for 242-A Evaporator campaigns 07-01 and 07-02 are presented in Appendix D. Campaigns 07-01 and 07-02 blended the waste of DSTs 241-AP-104 and 241-AW-102 together for evaporation and the analysis provides the case studies on a mixture of DST wastes. The resulting time to $25 \%$ of LFL at zero ventilation rate for different waste mixtures at various $\mathrm{SpG}$ and waste temperatures are summarized in Table 8-3.

Table 8-3. Summary of the Time to $25 \%$ of Lower Flammability Limit Under Zero Vent for Evaporator Campaign 07-01 and 07-02.

\begin{tabular}{|c|c|c|c|c|c|c|c|c|}
\hline $\begin{array}{l}\text { Cases of time to } 25 \% \\
\text { of the LFL (days) }\end{array}$ & $\begin{array}{c}\text { SpG } \\
1.6, \\
160^{\circ} \mathrm{F}\end{array}$ & $\begin{array}{c}\text { SpG } \\
1.7, \\
155^{\circ} \mathbf{F}\end{array}$ & $\begin{array}{c}\text { SpG } \\
1.6, \\
155^{\circ} \mathbf{F}\end{array}$ & $\begin{array}{c}\text { SpG } \\
1.6, \\
150^{\circ} \mathrm{F}\end{array}$ & $\begin{array}{c}\text { SpG } \\
1.55 \\
155^{\circ} \mathbf{F}\end{array}$ & $\begin{array}{c}\text { SpG } \\
1.55 \\
150^{\circ} \mathbf{F}\end{array}$ & $\begin{array}{c}\text { SpG } \\
1.50 \\
155^{\circ} \mathbf{F}\end{array}$ & $\begin{array}{c}\text { SpG } \\
1.50 \\
150^{\circ} \mathbf{F}\end{array}$ \\
\hline Raw 241-AP-104 & 2.33 & 2.29 & 3.04 & 3.94 & 3.49 & 4.53 & 4.01 & 5.20 \\
\hline $2 \mathrm{AW}-0.25 / 4 \mathrm{AP}-0.75$ & 2.12 & 2.11 & 2.76 & 3.58 & 3.16 & 4.10 & 3.62 & 4.70 \\
\hline $2 \mathrm{AW}-0.45 / 4 \mathrm{AP}-0.55$ & 2.03 & 2.05 & 2.64 & 3.43 & 3.01 & 3.90 & 3.44 & 4.47 \\
\hline $2 \mathrm{AW}-0.5 / 4 \mathrm{AP}-0.5$ & 2.01 & 2.04 & 2.62 & 3.40 & 2.98 & 3.87 & 3.41 & 4.43 \\
\hline $2 \mathrm{AW}-1.0 / 4 \mathrm{AP}-0.0$ & 2.08 & 2.21 & 2.69 & 3.0 & 3.01 & 3.91 & 3.37 & 4.41 \\
\hline Raw 241-AW-102 & 2.06 & 2.18 & 2.67 & 3.47 & 2.99 & 3.88 & 3.38 & 4.39 \\
\hline
\end{tabular}

Note:

The mixed waste case models different percentage of waste volume between $2 \mathrm{AW}$ and 4AP feed to evaporator. The 241-AW-102 waste in the mixture waste has been concentrated from the SpG of 1.07 to 1.28 to match the SpG of 241-AP-104 waste for better mixing. Thus the SpG of mixture waste starts at 1.28 and is concentrated to different target SpG at various temperatures. The cases of raw waste 241-AP-104 (at SpG 1.28) and 241-AW-102 (at SpG 1.07) are also included for comparison.

LFL = lower flammability limit.

The issue of adding the AFA has been intensively investigated by the Savannah River National Laboratory (WSRC-TR-2005-00281, Hydrogen Generation Rate Scoping Study of Dow Corning Antifoam Agent) for the Waste Treatment and Immobilization Plant at the Hanford Site. The investigation was to determine if the organic components of the AFAs produce hydrogen in the same manner as the native organic species in Hanford tank waste. The test results from this study indicate that the model calculated HGR bounds the measured HGRs from antifoamcontaining simulants if the antifoam organic components are treated the same as the native organics. 


\section{RPP-CALC-29700 REV 1}

During the evaporation process, starting when water is in the vessel, an AFA, DOW 1520, is injected. At the evaporator, it is diluted with water and then fed into the process at 0.01 to $0.1 \mathrm{gal} / \mathrm{min}$.

The intention of the following analysis is to examine the effect of the AFA on the HGRs and the time to reach $25 \%$ of the LFL. It is assumed, in the analysis, that the pure liquid AFA DOW 1520 has density of $1 \mathrm{~g} / \mathrm{mL}$ and $13 \mathrm{wt} \%$ of TOC (see Appendix F). Thus, the TOC concentration of pure liquid AFA is $0.13 \mathrm{~g} / \mathrm{mL}$, whereas the actual injected AFA liquid is diluted at least $1: 1$ with water. For given diluted AFA liquid with TOC concentration of $0.065 \mathrm{~g} / \mathrm{mL}$ and injection rate of $0.1 \mathrm{gal} / \mathrm{min}$ to the feed stream, the TOC concentration of the feed can be recalculated as follows.

$$
[T O C]_{\text {feed }}^{\text {new }}=\frac{R_{\text {feed }} \times[T O C]_{\text {feed }}^{\text {old }}+R_{A F A}[T O C]_{A F A}}{R_{\text {feed }}+R_{A F A}}
$$

where:

$$
\begin{aligned}
R_{\text {feed }}= & \text { the flow rate of feed stream (conservatively use } 70 \mathrm{gal} / \mathrm{min} \text {, from } \\
& \text { Table } 2-2, \mathrm{HNF}-14755) \\
R_{A F A}= & \text { the flow rate of AFA injection (use } 0.1 \mathrm{gal} / \mathrm{min} \text { ) }
\end{aligned}
$$

Considering an AFA injection rate of $0.1 \mathrm{gal} / \mathrm{min}$, the TOC concentration, HGRs, and time to reach $25 \%$ of the LFL are calculated for the waste of 28 DSTs at a reasonably conservative, targeted evaporation condition of $150{ }^{\circ} \mathrm{F}, 1.6 \mathrm{SpG}$ with $30 \%$ of feed ammonia remaining. The input data for 28 DSTs are the same as listed in Appendix A except the TOC concentrations are modified with Equation 8-1. The times to $25 \%$ of the LFL are given in Table 8-4.

In addition, the AFA might be used when the waste feed is stopped. The model calculations of the time to reach $25 \%$ of the LFL are also performed for the condition of mixing one, two, and three 55-gal drums (i.e., 55 gal, 110 gal, and 165 gal) of AFA with 26,000 gal of raw feed waste in the C-A-1 evaporator vessel. The calculation results are listed in Table 8-4. One drum (55 gal) of AFA is considered reasonably conservative based on the maximum injection rate of $0.1 \mathrm{gal} / \mathrm{min}$, experience with the quantity of AFA used during past and recent 242-A Evaporator campaigns, and the standard practice of shutting off the AFA when in recirculation (see Appendix G). Three drums (165 gal) of AFA in the C-A-1 evaporator vessel provides additional margin and is considered bounding. In addition, the antifoam tank TK-E-102 used to mix and supply antifoam solutions to the C-A-1 evaporator vessel only has a 100 gal capacity and, therefore, holds less than one 55-gal drum of AFA at a 1:1 dilution with water. Thus, operator action is required to add more than one drum.

For comparison, the TOC of raw feed liquid waste and the time to $25 \%$ of the LFL for the cases without AFA are listed in Table 8-4. Also, the percentage increase in TOC after addition of AFA and the ratio of the time to $25 \%$ of the LFL with and without AFA are given in Table 8-4. In general, the times to $25 \%$ of the LFL are shorter for the condition with one drum ( 55 gal) of AFA added than for the condition with AFA fed at $0.1 \mathrm{gal} / \mathrm{min}$ and for the condition of more drums of AFA due to the larger TOC increase. The addition of AFA may significantly affect the 


\section{RPP-CALC-29700 REV 1}

calculated time to $25 \%$ of the LFL. For example, the time to $25 \%$ of the LFL with zero ventilation for tank 241-AZ-102 is decreased from 3.6 to 3.2 days (an 11\% decrease) by the addition of one drum ( $55 \mathrm{gal}$ ) of AFA and from 3.6 to 2.6 days (a $28 \%$ decrease) by the addition of three drums (165 gal) of AFA.

Based on these results, the addition of three 55 -gal drums ( 165 gal) of AFA to the C-A-1 evaporator vessel should be included in the methodology of flammability analysis for the evaporator as required by TSR AC 5.6.1.9 (HNF-15279, Technical Safety Requirements for the 242-A Evaporator). 
Table 8-4. Total Organic Carbon and Time to $25 \%$ of the Lower Flammability Limit Calculations

With and Without Antifoam Agent. (2 sheets)

\begin{tabular}{|c|c|c|c|c|c|c|c|c|c|c|c|c|c|c|}
\hline \multirow[b]{2}{*}{$\begin{array}{l}\text { Tank Waste at } \\
\text { SpG } 1.6 \text {, temp. } \\
150^{\circ} \mathrm{F} \text { and } \\
30 \% \text { feed } \mathrm{NH}_{3}\end{array}$} & \multicolumn{2}{|c|}{ Without AFA } & \multicolumn{3}{|c|}{$0.1 \mathrm{gal} / \mathrm{min}$ AFA Feed } & \multicolumn{3}{|c|}{1 Drum (55 gal) AFA } & \multicolumn{3}{|c|}{2 Drum (110 gal) AFA } & \multicolumn{3}{|c|}{3 Drum (165 gal) AFA } \\
\hline & $\begin{array}{c}\text { Feed } \\
\text { Liquid } \\
\text { TOC } \\
(\mu \mathrm{g} / \mathrm{ml})\end{array}$ & \begin{tabular}{|c|} 
Time to \\
$25 \%$ LFL \\
no vent \\
(days)
\end{tabular} & $\begin{array}{c}\text { Time to } \\
25 \% \text { LFL } \\
\text { no vent } \\
\text { (days) }\end{array}$ & $\begin{array}{c}\text { TOC } \\
\text { increase } \\
\text { after } \\
\text { addition } \\
\text { of AFA } \\
(\%) \\
\end{array}$ & $\begin{array}{c}\text { TTLFL } \\
(25 \%) \\
\text { with/wo } \\
\text { AFA }\end{array}$ & $\begin{array}{c}\text { Time to } \\
25 \% \\
\text { LFL no } \\
\text { vent } \\
\text { (days) }\end{array}$ & $\begin{array}{c}\text { TOC } \\
\text { increase } \\
\text { after } \\
\text { addition } \\
\text { of AFA } \\
(\%) \\
\end{array}$ & $\begin{array}{c}\text { TTLFL } \\
(25 \%) \\
\text { with/wo } \\
\text { AFA }\end{array}$ & $\begin{array}{c}\text { Time to } \\
25 \% \\
\text { LFL no } \\
\text { vent } \\
\text { (days) }\end{array}$ & $\begin{array}{c}\text { TOC } \\
\text { increase } \\
\text { after } \\
\text { addition } \\
\text { of AFA } \\
(\%) \\
\end{array}$ & $\begin{array}{c}\text { TTLFL } \\
(25 \%) \\
\text { with/wo } \\
\text { AFA }\end{array}$ & $\begin{array}{l}\text { Time to } \\
25 \% \\
\text { LFL no } \\
\text { vent } \\
\text { (days) }\end{array}$ & $\begin{array}{c}\text { TOC } \\
\text { increase } \\
\text { after } \\
\text { addition } \\
\text { of AFA } \\
(\%) \\
\end{array}$ & $\begin{array}{c}\text { TTLFL } \\
(25 \%) \\
\text { with/wo } \\
\text { AFA }\end{array}$ \\
\hline 241-AN-101 & $5.11 \mathrm{E}+03$ & 5.7 & 5.6 & $1.7 \%$ & 0.98 & 5.4 & $5.4 \%$ & 0.95 & 5.2 & $10.7 \%$ & 0.90 & 4.9 & $16.0 \%$ & 0.86 \\
\hline 241-AN-102 & $2.41 \mathrm{E}+04$ & 1.3 & 1.3 & $0.2 \%$ & 0.99 & 1.3 & $1.0 \%$ & 0.99 & 1.3 & $1.9 \%$ & 0.98 & 1.3 & $2.9 \%$ & 0.97 \\
\hline $241-\mathrm{AN}-103$ & $3.05 \mathrm{E}+03$ & 8.8 & 8.6 & $2.9 \%$ & 0.97 & 8.1 & $9.1 \%$ & 0.92 & 7.5 & $18.2 \%$ & 0.85 & 7.0 & $27.3 \%$ & 0.79 \\
\hline 241-AN-104 & $3.14 \mathrm{E}+03$ & 6.0 & 5.8 & $2.8 \%$ & 0.97 & 5.5 & $8.9 \%$ & 0.92 & 5.1 & $17.7 \%$ & 0.85 & 4.7 & $26.5 \%$ & 0.79 \\
\hline $241-\mathrm{AN}-105$ & $2.76 \mathrm{E}+03$ & 7.6 & 7.3 & $3.2 \%$ & 0.97 & 6.9 & $10.1 \%$ & 0.91 & 6.3 & $20.2 \%$ & 0.83 & 5.8 & $30.2 \%$ & 0.77 \\
\hline $241-\mathrm{AN}-106$ & $2.10 \mathrm{E}+03$ & 4.1 & 3.9 & $4.3 \%$ & 0.96 & 3.6 & $13.4 \%$ & 0.88 & 3.2 & $26.7 \%$ & 0.79 & 2.9 & $40.0 \%$ & 0.71 \\
\hline 241-AN-107 & $3.25 \mathrm{E}+04$ & 2.6 & 2.6 & $0.1 \%$ & 1.00 & 2.6 & $0.7 \%$ & 0.99 & 2.6 & $1.3 \%$ & 0.98 & 2.5 & $2.0 \%$ & 0.98 \\
\hline 241-AP-101 & $1.90 \mathrm{E}+03$ & 14.0 & 13.3 & $4.8 \%$ & 0.95 & 12.2 & $14.8 \%$ & 0.87 & 10.8 & $29.6 \%$ & 0.77 & 9.7 & $44.3 \%$ & 0.69 \\
\hline 241-AP-102 & $3.01 \mathrm{E}+03$ & 7.0 & 6.8 & $3.0 \%$ & 0.97 & 6.4 & $9.3 \%$ & 0.91 & 5.9 & $18.5 \%$ & 0.84 & 5.5 & $27.7 \%$ & 0.78 \\
\hline 241-AP-103 & $7.27 \mathrm{E}+03$ & 3.2 & 3.1 & $1.1 \%$ & 0.99 & 3.1 & $3.7 \%$ & 0.97 & 3.0 & $7.4 \%$ & 0.93 & 2.9 & $11.1 \%$ & 0.90 \\
\hline 241-AP-104 & $4.15 E+03$ & 4.4 & 4.3 & $2.1 \%$ & 0.98 & 4.1 & $6.6 \%$ & 0.94 & 3.9 & $13.3 \%$ & 0.88 & 3.6 & $19.9 \%$ & 0.83 \\
\hline 241-AP-105 & $1.49 \mathrm{E}+03$ & 9.6 & 9.1 & $6.1 \%$ & 0.94 & 8.1 & $18.9 \%$ & 0.84 & 7.0 & $37.7 \%$ & 0.73 & 6.2 & $56.4 \%$ & 0.64 \\
\hline 241-AP-106 & $3.46 \mathrm{E}+03$ & 3.8 & 3.7 & $2.6 \%$ & 0.97 & 3.5 & $8.0 \%$ & 0.92 & 3.3 & $16.0 \%$ & 0.86 & 3.1 & $23.9 \%$ & 0.81 \\
\hline 241-AP-107 & $2.33 E+03$ & 7.5 & 7.3 & $3.9 \%$ & 0.96 & 6.7 & $12.0 \%$ & 0.89 & 6.1 & $24.0 \%$ & 0.81 & 5.6 & $35.9 \%$ & 0.73 \\
\hline 241-AP-108 & $4.18 \mathrm{E}+03$ & 6.2 & 6.1 & $2.1 \%$ & 0.98 & 5.8 & $6.6 \%$ & 0.94 & 5.5 & $13.2 \%$ & 0.88 & 5.2 & $19.7 \%$ & 0.84 \\
\hline 241-AW-101 & $2.61 \mathrm{E}+03$ & 11.4 & 11.0 & $3.4 \%$ & 0.97 & 10.3 & $10.7 \%$ & 0.90 & 9.4 & $21.4 \%$ & 0.82 & 8.7 & $32.0 \%$ & 0.76 \\
\hline 241-AW-102 & $2.25 \mathrm{E}+03$ & 8.1 & 7.8 & $4.0 \%$ & 0.96 & 7.2 & $12.5 \%$ & 0.89 & 6.5 & $24.9 \%$ & 0.80 & 5.9 & $37.2 \%$ & 0.73 \\
\hline 241-AW-103 & $2.06 \mathrm{E}+03$ & 6.1 & 5.9 & $4.4 \%$ & 0.96 & 5.4 & $13.6 \%$ & 0.88 & 4.8 & $27.2 \%$ & 0.79 & 4.4 & $40.7 \%$ & 0.71 \\
\hline 241-AW-104 & $4.32 \mathrm{E}+03$ & 4.8 & 4.8 & $2.0 \%$ & 0.98 & 4.6 & $6.4 \%$ & 0.94 & 4.3 & $12.8 \%$ & 0.89 & 4.1 & $19.1 \%$ & 0.84 \\
\hline $241-A W-105$ & $4.08 \mathrm{E}+02$ & 32.5 & 26.7 & $22.8 \%$ & 0.81 & 19.5 & $69.7 \%$ & 0.58 & 13.9 & $139.1 \%$ & 0.41 & 10.8 & $208.2 \%$ & 0.32 \\
\hline 241-AW-106 & $1.77 \mathrm{E}+03$ & 9.9 & 9.4 & $5.2 \%$ & 0.95 & 8.6 & $15.9 \%$ & 0.86 & 7.6 & $31.8 \%$ & 0.76 & 6.8 & $47.6 \%$ & 0.68 \\
\hline $241-\mathrm{AY}-101$ & $1.35 \mathrm{E}+03$ & 12.8 & 12.0 & $6.8 \%$ & 0.94 & 10.6 & $20.9 \%$ & 0.82 & 9.1 & $41.7 \%$ & 0.70 & 7.9 & $62.4 \%$ & 0.61 \\
\hline $241-\mathrm{AY}-102$ & $8.16 \mathrm{E}+02$ & 32.7 & 29.5 & $11.3 \%$ & 0.89 & 24.5 & $34.7 \%$ & 0.73 & 19.6 & $69.3 \%$ & 0.58 & 16.4 & $103.8 \%$ & 0.48 \\
\hline
\end{tabular}


Table 8-4. Total Organic Carbon and Time to $25 \%$ of the Lower Flammability Limit Calculations With and Without Antifoam Agent. (2 sheets)

\begin{tabular}{|c|c|c|c|c|c|c|c|c|c|c|c|c|c|c|}
\hline \multirow[b]{2}{*}{$\begin{array}{c}\text { Tank Waste at } \\
\text { SpG } 1.6, \text { temp. } \\
150{ }^{\circ} \mathrm{F} \text { and } \\
30 \% \text { feed } \mathrm{NH}_{3}\end{array}$} & \multicolumn{2}{|c|}{ Without AFA } & \multicolumn{3}{|c|}{$0.1 \mathrm{gal} / \mathrm{min}$ AFA Feed } & \multicolumn{3}{|c|}{1 Drum (55 gal) AFA } & \multicolumn{3}{|c|}{2 Drum (110 gal) AFA } & \multicolumn{3}{|c|}{3 Drum (165 gal) AFA } \\
\hline & $\begin{array}{c}\text { Feed } \\
\text { Liquid } \\
\text { TOC } \\
(\mu \mathrm{g} / \mathrm{ml})\end{array}$ & \begin{tabular}{|} 
Time to \\
$25 \%$ LFL \\
no vent \\
(days)
\end{tabular} & $\begin{array}{c}\text { Time to } \\
25 \% \text { LFL } \\
\text { no vent } \\
\text { (days) }\end{array}$ & $\begin{array}{c}\text { TOC } \\
\text { increase } \\
\text { after } \\
\text { addition } \\
\text { of AFA } \\
(\%) \\
\end{array}$ & $\begin{array}{c}\text { TTLFL } \\
(25 \%) \\
\text { with/wo } \\
\text { AFA }\end{array}$ & $\begin{array}{l}\text { Time to } \\
25 \% \\
\text { LFL no } \\
\text { vent } \\
\text { (days) }\end{array}$ & $\begin{array}{c}\text { TOC } \\
\text { increase } \\
\text { after } \\
\text { addition } \\
\text { of AFA } \\
(\%) \\
\end{array}$ & $\begin{array}{c}\text { TTLFL } \\
(25 \%) \\
\text { with/wo } \\
\text { AFA }\end{array}$ & $\begin{array}{c}\text { Time to } \\
25 \% \\
\text { LFL no } \\
\text { vent } \\
\text { (days) } \\
\end{array}$ & $\begin{array}{c}\text { TOC } \\
\text { increase } \\
\text { after } \\
\text { addition } \\
\text { of AFA } \\
(\%) \\
\end{array}$ & $\begin{array}{c}\text { TTLFL } \\
(25 \%) \\
\text { with/wo } \\
\text { AFA }\end{array}$ & $\begin{array}{l}\text { Time to } \\
25 \% \\
\text { LFL no } \\
\text { vent } \\
\text { (days) }\end{array}$ & $\begin{array}{c}\text { TOC } \\
\text { increase } \\
\text { after } \\
\text { addition } \\
\text { of AFA } \\
(\%) \\
\end{array}$ & $\begin{array}{c}\text { TTLFL } \\
(25 \%) \\
\text { with/wo } \\
\text { AFA }\end{array}$ \\
\hline 241-AZ-101 & $5.14 \mathrm{E}+02$ & 20.7 & 18.3 & $18.1 \%$ & 0.88 & 14.7 & $55.3 \%$ & 0.70 & 11.4 & $110.4 \%$ & 0.54 & 9.4 & $165.3 \%$ & 0.44 \\
\hline 241-AZ-102 & $1.99 \mathrm{E}+03$ & 3.6 & 3.5 & $4.6 \%$ & 0.96 & 3.2 & $14.1 \%$ & 0.88 & 2.9 & $28.1 \%$ & 0.79 & 2.6 & $42.1 \%$ & 0.71 \\
\hline $241-S Y-101$ & $2.30 \mathrm{E}+03$ & 9.6 & 9.2 & $3.9 \%$ & 0.96 & 8.6 & $12.2 \%$ & 0.89 & 7.7 & $24.3 \%$ & 0.80 & 7.1 & $36.3 \%$ & 0.73 \\
\hline 241-SY-102 & $1.24 \mathrm{E}+03$ & 17.3 & 16.1 & $7.4 \%$ & 0.93 & 14.1 & $22.7 \%$ & 0.81 & 12.0 & $45.3 \%$ & 0.68 & 10.4 & $67.9 \%$ & 0.59 \\
\hline 241-SY-103 & $6.22 \mathrm{E}+03$ & 3.4 & 3.3 & $1.4 \%$ & 0.99 & 3.2 & $4.4 \%$ & 0.96 & 3.1 & $8.7 \%$ & 0.92 & 3.0 & $13.0 \%$ & 0.89 \\
\hline
\end{tabular}

Notes:

$\mathrm{AFA}=$ antifoaming agent

LFL = lower flammability limit.

TOC $=$ total organic carbon

$\infty \quad$ TTLFL = time to lower flammability limit 
The flammability analyses for the shutdown mode (with 10,000 gal in the C-A-1 evaporator vessel) and the startup operation (with 26,000 gal in the C-A-1 evaporator vessel) of the evaporator process prior to liquid waste feed are presented in Appendix E. The shutdown mode and the startup operation do not involve slurry feed; only water, AFA, process condensate, and inhibited water (i.e., water treated with hydroxide and/or nitrite used for corrosion control). In the analyses, slightly contaminated process condensate collected in tank TK-C-100 is used as the bounding case. The shutdown and startup analyses both assumed the addition of three 55-gal drum of AFA. Table 8-5 lists the time to $25 \%$ of the LFL at zero ventilation for both shutdown and startup cases.

Table 8-5. Summary of Time to $25 \%$ of the Lower Flammability Limit for the Shutdown and Startup Modes.

\begin{tabular}{|c|c|c|c|c|c|}
\hline Tanks & Filled waste & $\begin{array}{c}\text { Time to } \\
\text { fraction f }\end{array}$ & $\begin{array}{c}\text { Reach } \\
\text { 25\% LFL at BB } \\
\text { vent (days) } \\
\text { Reach } \\
\text { fon\% LFL at BB } \\
\text { vent (days) }\end{array}$ & $\begin{array}{c}\text { Time to } \\
\text { Reach } \\
\text { 25 LF at Zero } \\
\text { vent (days) }\end{array}$ & $\begin{array}{c}\text { Time to } \\
\text { Reach } \\
\text { Zero vent (days) }\end{array}$ \\
\hline Shutdown mode & 0.24 & not occur & not occur & $>2000$ & $>2000$ \\
\hline Start-up mode & 0.62 & not occur & not occur & 1079 & 1755 \\
\hline
\end{tabular}

Notes:

$\mathrm{BB}=$ barometric breathing.

LFL = lower flammability limit.

\subsection{FLAMMABILITY LEVEL ON TK-C-100 UNDER AMBIENT PRESSURE}

Tank TK-C-100 collects the liquid condensation from the primary condenser, inter-condenser, and after-condenser and operates at ambient temperature $\left(85^{\circ} \mathrm{F}\right)$ and pressure $(1 \mathrm{~atm})$. The condensation contains mainly contaminated water with dissolved ammonia. The concentrations of radionuclides and other chemicals are small and can be ignored in this analysis. Thus, the flammability analysis includes only hydrogen generation from corrosion and the ammonia concentration at equilibrium between the liquid and vapor phases. Results are calculated at various (10\% increments) up to the level of overflow (about $85 \%$ full).

Table 8-6 lists the ammonia concentrations from analysis of samples from condensate tank TK-C-100. Two ammonia liquid concentrations of 0.29 and $0.77 \mathrm{~g} / \mathrm{L}$ (from March 22, 2005, and September, 3, 2003, respectively) were chosen for use in the flammability analysis. 
Table 8-6. Measured Ammonia Concentration in Condensate Tank TK-C-100.

\begin{tabular}{|c|c|}
\hline Sample Date & $\begin{array}{c}\text { Ammonia sample } \\
\text { concentration* } \\
(\mu \mathrm{g} / \mathbf{m L})\end{array}$ \\
\hline $04 / 25 / 00$ & 118 \\
\hline $04 / 26 / 00$ & 108 \\
\hline $05 / 02 / 00$ & 145 \\
\hline $03 / 18 / 01$ & 58 \\
\hline $03 / 21 / 01$ & 65 \\
\hline $09 / 02 / 03$ & 752 \\
\hline $09 / 03 / 03$ & 769 \\
\hline $03 / 18 / 04$ & 57 \\
\hline $03 / 24 / 04$ & 84 \\
\hline $03 / 22 / 05$ & 289 \\
\hline $03 / 24 / 05$ & 204 \\
\hline
\end{tabular}

Note:

*RPP-21926, 2004, 242-A Evaporator Vapor

Emissions Estimate Using Environmental Simulation

Program (ESP) Model, Appendix B, Rev. 0, CH2M HILL

Hanford Group, Inc., Richland, Washington.

The $\mathrm{NH}_{4}{ }^{+}$concentration in the stream that exits the condensate tank is $2.3 \mathrm{~g} / \mathrm{L}$ according to the process flow data in HNF-14755, Table 2B. This indicates that the ammonia concentrations in Table 8-6 may not be bounding. Therefore, at the request of a 242-A Evaporator process engineer, flammability analyses were performed for condensate ammonia concentrations of 3 and $6.8 \mathrm{~g} / \mathrm{L}$. Details of the calculation results are given in Appendix C. Table 8-7 summarizes the time to $25 \%$ of the LFL under both barometric breathing and zero ventilation conditions.

As shown in Table 8-7, none of the conditions will exceed the $25 \%$ of the LFL under the barometric breathing condition. Under zero ventilation, the shortest time to reach $25 \%$ of the LFL is 432 days when the waste is $85 \%$ full at the ammonia concentration of $6.8 \mathrm{~g} / \mathrm{L}$. 


\section{RPP-CALC-29700 REV 1}

Table 8-7. Steady-State Flammability and Time to Lower Flammability Limit for TK-C-100 of 242-A Evaporator. (2 sheets)

\begin{tabular}{|c|c|c|c|c|c|c|c|c|c|}
\hline Tanks & $\begin{array}{c}\text { Filled } \\
\text { fraction }\end{array}$ & $\begin{array}{l}\text { Time to } \\
\text { reach } \\
25 \% \\
\text { LFL at } \\
\text { BB vent } \\
\text { (days) }\end{array}$ & $\begin{array}{l}\text { Time to } \\
\text { reach } \\
100 \% \\
\text { LFL at } \\
\text { BB vent } \\
\text { (days) }\end{array}$ & $\begin{array}{l}\text { Time to } \\
\text { reach } \\
25 \% \\
\text { LFL at } \\
\text { zero vent } \\
\text { (days) }\end{array}$ & $\begin{array}{l}\text { Time to } \\
\text { reach } \\
100 \% \\
\text { LFL at } \\
\text { zero vent } \\
\text { (days) }\end{array}$ & $\begin{array}{c}\text { Steady- } \\
\text { state } \\
\mathrm{NH}_{3} \\
\mathrm{LFL} \\
(\%)\end{array}$ & $\begin{array}{c}\text { Steady- } \\
\text { state } \\
\mathrm{H}_{2} \\
\text { LFL } \\
(\%)\end{array}$ & $\begin{array}{c}\text { Steady- } \\
\text { state } \\
\text { CH }_{4} \\
\text { LFL } \\
(\%)\end{array}$ & $\begin{array}{c}\text { Steady- } \\
\text { state } \\
\text { LFL at } \\
\text { BB } \\
(\%)\end{array}$ \\
\hline \multirow{9}{*}{$\begin{array}{c}\text { 05-01 (2005) } \\
\text { campaign } \\
\text { (RPP-RPT- } \\
27963) \text { with } \\
\mathrm{NH}_{3} \\
\text { concentration } \\
\text { of } 0.289 \mathrm{~g} / \mathrm{L} \\
\text { at } \\
\text { temperature } \\
\text { of } 85^{\circ} \mathrm{F} \\
\text { water }\end{array}$} & 0.10 & not occur & not occur & 2,000 & 2,000 & $0.2 \%$ & $0.5 \%$ & $0.00 \%$ & $0.8 \%$ \\
\hline & 0.20 & not occur & not occur & 2,000 & 2,000 & $0.2 \%$ & $0.8 \%$ & $0.00 \%$ & $1.0 \%$ \\
\hline & 0.30 & not occur & not occur & 2,000 & 2,000 & $0.2 \%$ & $1.1 \%$ & $0.00 \%$ & $1.3 \%$ \\
\hline & 0.40 & not occur & not occur & 2,000 & 2,000 & $0.2 \%$ & $1.5 \%$ & $0.00 \%$ & $1.7 \%$ \\
\hline & 0.50 & not occur & not occur & 2,000 & 2,000 & $0.2 \%$ & $2.1 \%$ & $0.00 \%$ & $2.3 \%$ \\
\hline & 0.60 & not occur & not occur & 1,899 & 2,000 & $0.2 \%$ & $2.9 \%$ & $0.00 \%$ & $3.2 \%$ \\
\hline & 0.70 & not occur & not occur & 1,270 & 2,000 & $0.2 \%$ & $4.4 \%$ & $0.00 \%$ & $4.6 \%$ \\
\hline & 0.80 & not occur & not occur & 764 & 2,000 & $0.2 \%$ & $7.2 \%$ & $0.00 \%$ & $7.5 \%$ \\
\hline & 0.85 & not occur & not occur & 547 & 2,000 & $0.2 \%$ & $10.1 \%$ & $0.00 \%$ & $10.3 \%$ \\
\hline \multirow{9}{*}{$\begin{array}{c}9 / 3 / 2003 \\
\text { sample of } \\
\mathrm{NH}_{3} \\
\text { concentration } \\
\text { of } 0.769 \mathrm{~g} / \mathrm{L} \\
\text { at } \\
\text { temperature } \\
\text { of } 85^{\circ} \mathrm{F} \\
\text { water }\end{array}$} & 0.10 & not occur & not occur & 2,000 & 2,000 & $0.6 \%$ & $0.5 \%$ & $0.00 \%$ & $1.1 \%$ \\
\hline & 0.20 & not occur & not occur & 2,000 & 2,000 & $0.6 \%$ & $0.8 \%$ & $0.00 \%$ & $1.4 \%$ \\
\hline & 0.30 & not occur & not occur & 2,000 & 2,000 & $0.6 \%$ & $1.1 \%$ & $0.00 \%$ & $1.7 \%$ \\
\hline & 0.40 & not occur & not occur & 2,000 & 2,000 & $0.6 \%$ & $1.5 \%$ & $0.00 \%$ & $2.1 \%$ \\
\hline & 0.50 & not occur & not occur & 2,000 & 2,000 & $0.6 \%$ & $2.1 \%$ & $0.00 \%$ & $2.7 \%$ \\
\hline & 0.60 & not occur & not occur & 1,870 & 2,000 & $0.6 \%$ & $2.9 \%$ & $0.00 \%$ & $3.5 \%$ \\
\hline & 0.70 & not occur & not occur & 1,251 & 2,000 & $0.6 \%$ & $4.4 \%$ & $0.00 \%$ & $5.0 \%$ \\
\hline & 0.80 & not occur & not occur & 752 & 2,000 & $0.6 \%$ & $7.2 \%$ & $0.00 \%$ & $7.8 \%$ \\
\hline & 0.85 & not occur & not occur & 538 & 2,000 & $0.6 \%$ & $10.1 \%$ & $0.00 \%$ & $10.7 \%$ \\
\hline \multirow{9}{*}{$\begin{array}{c}\text { Case of } \mathrm{NH}_{3} \\
\text { concentration } \\
\text { of } 3 \mathrm{~g} / \mathrm{L} \\
\text { at } \\
\text { temperature } \\
\text { of } 85^{\circ} \mathrm{F} \\
\text { water }\end{array}$} & 0.10 & not occur & not occur & 2,000 & 2,000 & $2.4 \%$ & $0.5 \%$ & $0.00 \%$ & $2.9 \%$ \\
\hline & 0.20 & not occur & not occur & 2,000 & 2,000 & $2.4 \%$ & $0.8 \%$ & $0.00 \%$ & $3.2 \%$ \\
\hline & 0.30 & not occur & not occur & 2,000 & 2,000 & $2.4 \%$ & $1.1 \%$ & $0.00 \%$ & $3.5 \%$ \\
\hline & 0.40 & not occur & not occur & 2,000 & 2,000 & $2.4 \%$ & $1.5 \%$ & $0.00 \%$ & $3.9 \%$ \\
\hline & 0.50 & not occur & not occur & 2,000 & 2,000 & $2.4 \%$ & $2.1 \%$ & $0.00 \%$ & $4.4 \%$ \\
\hline & 0.60 & not occur & not occur & 1,733 & 2,000 & $2.4 \%$ & $2.9 \%$ & $0.00 \%$ & $5.3 \%$ \\
\hline & 0.70 & not occur & not occur & 1,160 & 2,000 & $2.4 \%$ & $4.4 \%$ & $0.00 \%$ & $6.7 \%$ \\
\hline & 0.80 & not occur & not occur & 698 & 2,000 & $2.4 \%$ & $7.2 \%$ & $0.00 \%$ & $9.6 \%$ \\
\hline & 0.85 & not occur & not occur & 499 & 2,000 & $2.4 \%$ & $10.1 \%$ & $0.00 \%$ & $12.5 \%$ \\
\hline
\end{tabular}


Table 8-7. Steady-State Flammability and Time to Lower Flammability Limit for TK-C-100 of 242-A Evaporator. (2 sheets)

\begin{tabular}{|c|c|c|c|c|c|c|c|c|c|}
\hline Tanks & $\begin{array}{l}\text { Filled } \\
\text { fraction }\end{array}$ & $\begin{array}{l}\text { Time to } \\
\text { reach } \\
25 \% \\
\text { LFL at } \\
\text { BB vent } \\
\text { (days) }\end{array}$ & $\begin{array}{l}\text { Time to } \\
\text { reach } \\
100 \% \\
\text { LFL at } \\
\text { BB vent } \\
\text { (days) }\end{array}$ & $\begin{array}{l}\text { Time to } \\
\text { reach } \\
25 \% \\
\text { LFL at } \\
\text { zero vent } \\
\text { (days) }\end{array}$ & $\begin{array}{c}\text { Time to } \\
\text { reach } \\
100 \% \\
\text { LFL at } \\
\text { zero vent } \\
\text { (days) }\end{array}$ & $\begin{array}{c}\text { Steady- } \\
\text { state } \\
\mathrm{NH}_{3} \\
\mathrm{LFL} \\
(\%)\end{array}$ & $\begin{array}{c}\text { Steady- } \\
\text { state } \\
\mathrm{H}_{2} \\
\text { LFL } \\
(\%)\end{array}$ & $\begin{array}{c}\text { Steady- } \\
\text { state } \\
\text { CH }_{4} \\
\text { LFL } \\
(\%)\end{array}$ & $\begin{array}{c}\text { Steady- } \\
\text { state } \\
\text { LFL at } \\
\text { BB } \\
(\%)\end{array}$ \\
\hline \multirow{9}{*}{$\begin{array}{c}\text { Case of } \mathrm{NH}_{3} \\
\text { concentration } \\
\text { of } 6.8 \mathrm{~g} / \mathrm{L} \\
\text { at } \\
\text { temperature } \\
\text { of } 85^{\circ} \mathrm{F} \\
\text { water }\end{array}$} & 0.10 & not occur & not occur & 2,000 & 2,000 & $5.4 \%$ & $0.5 \%$ & $0.00 \%$ & $5.9 \%$ \\
\hline & 0.20 & not occur & not occur & 2,000 & 2,000 & $5.4 \%$ & $0.8 \%$ & $0.00 \%$ & $6.2 \%$ \\
\hline & 0.30 & not occur & not occur & 2,000 & 2,000 & $5.4 \%$ & $1.1 \%$ & $0.00 \%$ & $6.5 \%$ \\
\hline & 0.40 & not occur & not occur & 2,000 & 2,000 & $5.4 \%$ & $1.5 \%$ & $0.00 \%$ & $6.9 \%$ \\
\hline & 0.50 & not occur & not occur & 2,000 & 2,000 & $5.4 \%$ & $2.1 \%$ & $0.00 \%$ & $7.5 \%$ \\
\hline & 0.60 & not occur & not occur & 1,501 & 2,000 & $5.4 \%$ & $2.9 \%$ & $0.00 \%$ & $8.3 \%$ \\
\hline & 0.70 & not occur & not occur & 1,004 & 2,000 & $5.4 \%$ & $4.4 \%$ & $0.00 \%$ & $9.7 \%$ \\
\hline & 0.80 & not occur & not occur & 605 & 2,000 & $5.4 \%$ & $7.2 \%$ & $0.00 \%$ & $12.6 \%$ \\
\hline & 0.85 & not occur & not occur & 432 & 2,000 & $5.4 \%$ & $10.1 \%$ & $0.00 \%$ & $15.5 \%$ \\
\hline
\end{tabular}

Notes:

RPP-RPT-27963, 2005, 242-A Evaporator Campaign 05-01 Vapor Emissions Evaluation, Rev. 0, CH2M HILL Hanford Group, Inc., Richland, Washington.

$\mathrm{BB}=$ barometric breathing.

LFL = lower flammability limit.

\subsection{FLAMMABILITY LEVEL ON GASEOUS EFFLUENT AFTER PRIMARY CONDENSER UNDER VACUUM}

During the normal evaporation process, the evaporator runs under vacuum and high temperature. For the headspace of $\mathrm{C}-\mathrm{A}-1$, during the normal evaporation process, the majority of the vapor is water with some ammonia, hydrogen, and methane; there is very limited air and thus no flammable gas concern. This is also true for the 42-in. pipeline between the C-A-1 vessel and primary condenser. Since air flow is introduced to and joins with the exit vapors from the primary condenser, a flammability analysis for the gaseous effluent after the primary condenser was conducted. A bounding case of waste temperature $155^{\circ} \mathrm{F}$ and $\mathrm{SpG}$ of 1.6 is evaluated for all 28 DSTs on the C-A-1 vessel under vacuum condition using Equations 6-15 to 6-21. The parameters used in the calculations are summarized in Table 8-8, including the in-leakage air flow (at $1 \mathrm{~atm}$ ), the feed flow rate, the slurry flow rate, the ammonia fraction of the feed to slurry, the ammonia fraction of the vapor stream from headspace survived after primary condensation. 
Table 8-8. Parameters Used in the Flammability Analysis on C-A-1 Under Vacuum Condition.

\begin{tabular}{|c|c|c|c|c|c|c|c|c|}
\hline Parameters & $\begin{array}{c}\operatorname{Air}^{\mathrm{a}} \\
(\mathrm{L} / \mathrm{min})\end{array}$ & $\begin{array}{c}\text { Feed }^{\mathrm{d}} \\
(\mathrm{L} / \mathrm{min})\end{array}$ & $\begin{array}{l}\text { Slurry }^{\mathrm{d}} \\
(\mathrm{L} / \mathrm{min})\end{array}$ & $\begin{array}{c}\text { Slurry } \\
\text { NH }_{3} \text { frac }\end{array}$ & $\begin{array}{c}\text { Vent } \\
\mathbf{N H}_{3} \text { frac } \\
\end{array}$ & $\begin{array}{c}\mathrm{NH}_{3} \\
\text { (g/mole) }\end{array}$ & $\begin{array}{l}\text { Volume } \\
\text { (gallon) }\end{array}$ & $\begin{array}{c}\text { Conversion } \\
\text { (liter/gallon) }\end{array}$ \\
\hline Values & 740 & 494 & 265 & 0.1 & 0.0857 & 17.03 & 26,000 & 3.7854 \\
\hline
\end{tabular}

Notes:

${ }^{\mathrm{a}}$ Air rate from stream 27 (HNF-14755, Table 2B-1).

${ }^{\mathrm{b}}$ Ratio of Stream 1 and 2 (HNF-14755, Table 2B-1).

${ }^{c}$ Ratio of Stream 6 and 4 (HNF-14755, Table 2B-1).

${ }^{\mathrm{d}} \mathrm{HNF}-14755$, Table 2-2.

HNF-14755, Documented Safety Analysis for the 242-A Evaporator, as amended, CH2M HILL Hanford Group, Inc., Richland, Washington.

The results of the flammability analysis on the gaseous effluent after primary condenser are summarized in Table 8-9. A sensitivity check of the total flammability on the ammonia fraction of the vapor stream to the vent is performed using the fraction at 0.1 instead of 0.086 and the results are listed in the last column of Table 8-9. The results show that ammonia is the dominant fraction of total flammability. The highest total flammability is $58 \%$ and $67 \%$ of the LFL on the $\mathrm{NH}_{3}$ fraction to vent at 0.086 and 0.1 , respectively. Note that the flammability is linearly proportional to ammonia concentration in the feed liquid waste and inversely proportional to the in-leakage air flow. This analysis reviewed 28 DST current liquids using the air flow rate at the 30 torr condition. If the same flow rate was maintained, and the ammonia concentration was increased to $2.4 \mathrm{~g} / \mathrm{L}$, the gaseous effluent after the primary condenser would reach $100 \%$ of the LFL. Or, if the air flow drops by $46 \%$ while processing the current bounding tank liquid at its highest ammonia concentration $(1.29 \mathrm{~g} / \mathrm{L})$, the gaseous effluent after the primary condenser would reach $100 \%$ of the LFL. 
Table 8-9. Flammability of the Gaseous Effluent After Primary Condenser with Air In-Leakage. (2 sheets)

\begin{tabular}{|c|c|c|c|c|c|c|c|c|c|}
\hline Tank ID & $\begin{array}{c}\text { Feed } \\
\text { liquid } \mathrm{NH}_{3} \\
(\mu \mathrm{g} / \mathrm{ml})\end{array}$ & $\begin{array}{c}\mathrm{U}_{\mathrm{H} 2} \\
\text { unit rate of } \\
\text { hydrogen } \\
\text { (mole/min) }\end{array}$ & $\begin{array}{c}\mathrm{U}_{\mathrm{CH} 4} \\
\text { unit rate of } \\
\text { methane } \\
(\text { mole/min) }\end{array}$ & $\begin{array}{c}\text { Nominal } \\
\mathbf{U}_{\mathrm{NH} 3} \text { vapor } \\
\text { form C-A-1 } \\
\text { to vent at } \\
0.086 \\
\text { (mole } / \mathrm{min})\end{array}$ & $\begin{array}{c}\text { Nominal } \\
\text { hydrogen } \\
\mathbf{H}_{\mathbf{2}} \\
(\% \mathrm{LFL})\end{array}$ & $\begin{array}{c}\text { Nominal } \\
\text { methane } \\
\mathrm{CH}_{4} \\
(\% \text { LFL })\end{array}$ & $\begin{array}{c}\text { Nominal } \\
\text { ammonia } \\
\mathrm{NH}_{3} \\
(\% \text { LFL) }\end{array}$ & $\begin{array}{c}\text { Nominal } \\
\text { total flamm. } \\
\text { (\%LFL) } \\
\text { with } \mathrm{NH}_{3^{-}} \\
\text {vent at } \\
\mathbf{0 . 0 8 6} \\
\end{array}$ & $\begin{array}{c}\text { Sensitivity } \\
\text { check total } \\
\text { flamm. } \\
\text { (\%LFL) } \\
\text { with } \mathrm{NH}_{3^{-}} \\
\text {vent at } 0.1 \\
\end{array}$ \\
\hline 241-AN-101 & $1.68 \mathrm{E}+02$ & $3.07 \mathrm{E}-03$ & $3.06 \mathrm{E}-04$ & 0.396 & 0.06 & 0.01 & 8.19 & 8.3 & 9.6 \\
\hline 241-AN-102 & $2.10 \mathrm{E}+02$ & $1.30 \mathrm{E}-02$ & $1.30 \mathrm{E}-03$ & 0.494 & 0.27 & 0.03 & 10.17 & 10.5 & 12.1 \\
\hline 241-AN-103 & $3.45 \mathrm{E}+02$ & $1.84 \mathrm{E}-03$ & $1.83 \mathrm{E}-04$ & 0.812 & 0.04 & 0.00 & 16.56 & 16.6 & 19.3 \\
\hline 241-AN-104 & $2.46 \mathrm{E}+02$ & $2.66 \mathrm{E}-03$ & $2.65 \mathrm{E}-04$ & 0.579 & 0.05 & 0.01 & 11.89 & 12.0 & 13.9 \\
\hline 241-AN-105 & $2.10 \mathrm{E}+02$ & $2.18 \mathrm{E}-03$ & $2.17 \mathrm{E}-04$ & 0.494 & 0.05 & 0.00 & 10.18 & 10.2 & 11.9 \\
\hline 241-AN-106 & $2.10 \mathrm{E}+02$ & $4.28 \mathrm{E}-03$ & $4.27 \mathrm{E}-04$ & 0.494 & 0.09 & 0.01 & 10.18 & 10.3 & 11.9 \\
\hline 241-AN-107 & $2.10 \mathrm{E}+02$ & $6.70 \mathrm{E}-03$ & $6.69 \mathrm{E}-04$ & 0.494 & 0.14 & 0.01 & 10.18 & 10.3 & 12.0 \\
\hline 241-AP-101 & $4.39 \mathrm{E}+02$ & $1.21 \mathrm{E}-03$ & $1.20 \mathrm{E}-04$ & 1.033 & 0.02 & 0.00 & 20.93 & 21.0 & 24.3 \\
\hline 241-AP-102 & $4.39 \mathrm{E}+02$ & $2.34 \mathrm{E}-03$ & $2.33 \mathrm{E}-04$ & 1.033 & 0.05 & 0.00 & 20.93 & 21.0 & 24.3 \\
\hline 241-AP-103 & $2.50 \mathrm{E}+02$ & $5.34 \mathrm{E}-03$ & $5.33 \mathrm{E}-04$ & 0.588 & 0.11 & 0.01 & 12.08 & 12.2 & 14.2 \\
\hline 241-AP-104 & $1.33 \mathrm{E}+02$ & $4.04 \mathrm{E}-03$ & $4.03 \mathrm{E}-04$ & 0.313 & 0.08 & 0.01 & 6.48 & 6.6 & 7.6 \\
\hline 241-AP-105 & $3.24 \mathrm{E}+02$ & $1.61 \mathrm{E}-03$ & $1.60 \mathrm{E}-04$ & 0.762 & 0.03 & 0.00 & 15.57 & 15.6 & 18.1 \\
\hline 241-AP-106 & $6.75 \mathrm{E}+01$ & $4.65 \mathrm{E}-03$ & $4.64 \mathrm{E}-04$ & 0.159 & 0.10 & 0.01 & 3.31 & 3.4 & 4.0 \\
\hline 241-AP-107 & $1.14 \mathrm{E}+03$ & $2.11 \mathrm{E}-03$ & $2.10 \mathrm{E}-04$ & 2.682 & 0.04 & 0.00 & 51.75 & 51.8 & 59.7 \\
\hline 241-AP-108 & $9.63 \mathrm{E}+02$ & $2.54 \mathrm{E}-03$ & $2.53 \mathrm{E}-04$ & 2.267 & 0.05 & 0.00 & 44.27 & 44.3 & 51.1 \\
\hline 241-AW-101 & $1.00 \mathrm{E}+01$ & $1.57 \mathrm{E}-03$ & $1.56 \mathrm{E}-04$ & 0.024 & 0.03 & 0.00 & 0.49 & 0.5 & 0.6 \\
\hline 241-AW-102 & $7.43 \mathrm{E}+01$ & $2.20 \mathrm{E}-03$ & $2.19 \mathrm{E}-04$ & 0.175 & 0.05 & 0.00 & 3.64 & 3.7 & 4.3 \\
\hline 241-AW-103 & $5.12 \mathrm{E}+02$ & $2.42 \mathrm{E}-03$ & $2.41 \mathrm{E}-04$ & 1.205 & 0.05 & 0.00 & 24.28 & 24.3 & 28.2 \\
\hline 241-AW-104 & $1.69 \mathrm{E}+02$ & $3.62 \mathrm{E}-03$ & $3.61 \mathrm{E}-04$ & 0.398 & 0.07 & 0.01 & 8.21 & 8.3 & 9.6 \\
\hline 241-AW-105 & $1.01 \mathrm{E}+03$ & $5.21 \mathrm{E}-04$ & $5.09 \mathrm{E}-05$ & 2.376 & 0.01 & 0.00 & 46.26 & 46.3 & 53.4 \\
\hline 241-AW-106 & $3.55 \mathrm{E}+02$ & $1.70 \mathrm{E}-03$ & $1.69 \mathrm{E}-04$ & 0.835 & 0.03 & 0.00 & 17.03 & 17.1 & 19.8 \\
\hline 241-AY-101 & $1.13 \mathrm{E}+02$ & $1.34 \mathrm{E}-03$ & $1.33 \mathrm{E}-04$ & 0.266 & 0.03 & 0.00 & 5.52 & 5.5 & 6.5 \\
\hline
\end{tabular}


Table 8-9. Flammability of the Gaseous Effluent After Primary Condenser with Air In-Leakage. (2 sheets)

\begin{tabular}{|c|c|c|c|c|c|c|c|c|c|}
\hline Tank ID & $\begin{array}{c}\text { Feed } \\
\text { liquid } \mathrm{NH}_{3} \\
(\mu \mathrm{g} / \mathrm{ml})\end{array}$ & $\begin{array}{c}\mathrm{U}_{\mathrm{H2}} \\
\text { unit rate of } \\
\text { hydrogen } \\
\text { (mole/min) }\end{array}$ & $\begin{array}{c}\mathrm{U}_{\mathrm{CH} 4} \\
\text { unit rate of } \\
\text { methane } \\
\text { (mole/min) }\end{array}$ & $\begin{array}{c}\text { Nominal } \\
\mathrm{U}_{\mathrm{NH} 3} \text { vapor } \\
\text { form C-A-1 } \\
\text { to vent at } \\
0.086 \\
\text { (mole/min) }\end{array}$ & $\begin{array}{c}\text { Nominal } \\
\text { hydrogen } \\
\mathrm{H}_{2} \\
(\% \text { LFL) }\end{array}$ & $\begin{array}{c}\text { Nominal } \\
\text { methane } \\
\text { CH }_{4} \\
(\% \text { LFL })\end{array}$ & $\begin{array}{c}\text { Nominal } \\
\text { ammonia } \\
\text { NH }_{3} \\
(\% \text { LFL) }\end{array}$ & $\begin{array}{c}\text { Nominal } \\
\text { total flamm. } \\
(\% \mathrm{LFL}) \\
\text { with } \mathrm{NH}_{3-} \\
\text { vent at } \\
0.086\end{array}$ & $\begin{array}{c}\text { Sensitivity } \\
\text { check total } \\
\text { flamm. } \\
(\% \mathrm{LFL}) \\
\text { with } \mathrm{NH}_{3-} \\
\text { vent at } 0.1\end{array}$ \\
\hline 241-AY-102 & $7.37 \mathrm{E}+01$ & $5.44 \mathrm{E}-04$ & $5.32 \mathrm{E}-05$ & 0.173 & 0.01 & 0.00 & 3.61 & 3.6 & 4.2 \\
\hline $241-A Z-101$ & $1.25 \mathrm{E}+02$ & $7.83 \mathrm{E}-04$ & $7.71 \mathrm{E}-05$ & 0.294 & 0.02 & 0.00 & 6.10 & 6.1 & 7.1 \\
\hline $241-\mathrm{AZ}-102$ & $4.38 \mathrm{E}+02$ & $3.91 \mathrm{E}-03$ & $3.90 \mathrm{E}-04$ & 1.031 & 0.08 & 0.01 & 20.88 & 21.0 & 24.3 \\
\hline $241-S Y-101$ & $1.04 \mathrm{E}+03$ & $1.61 \mathrm{E}-03$ & $1.60 \mathrm{E}-04$ & 2.456 & 0.03 & 0.00 & 47.71 & 47.7 & 55.0 \\
\hline 241-SY-102 & $1.15 \mathrm{E}+03$ & $9.60 \mathrm{E}-04$ & $9.49 \mathrm{E}-05$ & 2.706 & 0.02 & 0.00 & 52.17 & 52.2 & 60.1 \\
\hline $241-S Y-103$ & $1.29 \mathrm{E}+03$ & $4.09 \mathrm{E}-03$ & $4.08 \mathrm{E}-04$ & 3.035 & 0.08 & 0.01 & 57.97 & 58.1 & 66.7 \\
\hline
\end{tabular}

Note:

LFL = lower flammability limit. 
RPP-CALC-29700 REV 1

\subsection{CONCLUSIONS}

Flammability evaluations of the evaporation process at the 242-A Evaporator were performed. Three facilities under two conditions of ambient pressure and low vacuum were identified: C-A-1 headspace, gaseous effluent after primary condenser, and condensate tank TK-C-100. Detailed flammability analyses using the liquid waste from 28 DSTs (from RPP-5926) were conducted. In addition, the flammability analyses on a waste mixture from DSTs 241-AP-104 and 241-AW-102 from evaporation campaigns 07-1 and 07-02 were performed. The flammability analyses of the shutdown mode and startup operation with water addition were also performed.

For the waste remaining in the C-A-1 evaporator vessel under ambient pressure (upset offnormal process condition or before/after evaporation process), headspace of C-A-1 can reach $25 \%$ of the LFL in a little as 1 day for DST 241-AN-102 liquid waste in the case of target slurry $\mathrm{SpG}$ of 1.6 and waste temperature of $155^{\circ} \mathrm{F}$ assuming $30 \%$ of the ammonia remains in the waste under either barometric breathing or the zero ventilation condition. The headspace of C-A-1 includes the extended vapor space of the gaseous effluent pathway, a 42-in. pipeline between C-A-1 and the primary condenser, and the vapor space in the primary condenser. In general, the flammability level is linearly proportional to the targeted slurry SpG and exponentially proportional to operational temperature or waste temperature. For a given ammonia concentration (maximum of $1.3 \mathrm{~g} / \mathrm{L}$ in the $28 \mathrm{DSTs}$ ), and assuming $30 \%$ of the feed ammonia remains in the evaporator vessel, hydrogen is still the dominant contributor to the total flammability.

The flammability level calculation of condensate tank TK-C-100 was conducted at various fill fractions in $10 \%$ increments up to the level of overflow, which is $85 \%$. The condensate tank collects condensate, which is mainly contaminated water plus soluble ammonia of concern from all three condensers and operates at ambient pressure $(1 \mathrm{~atm})$ and ambient temperature (assumed as $85^{\circ} \mathrm{F}$ ). The analysis considers only the hydrogen generated from corrosion and the ammonia concentration at equilibrium. Four ammonia concentrations up to $6.8 \mathrm{~g} / \mathrm{L}$ were evaluated. The results show that none of the cases will reach $25 \%$ of the LFL under barometric breathing and under zero ventilation the shortest time to reach $25 \%$ of the LFL is 432 days when the tank is $85 \%$ filled with an ammonia concentration of $6.8 \mathrm{~g} / \mathrm{L}$.

During the normal evaporation process, the liquid waste in the C-A-1 evaporator vessel is evaporated under a vacuum (60 to 80 torr) and heated to an operational temperature (140 to $160^{\circ} \mathrm{F}$ ). Flammability is not a concern in the headspace of C-A-1, the 42 -in. connecting pipeline or the vapor space of the primary condenser since the majority of the vapor generated is water with no air. The exit vapor streams after the primary condenser are mixed with in-leakage air flow and forms a mixture of air and flammable gases. Detailed flammability analyses have been conducted on the mixture of air and flammable gases after the primary condenser; the results show that the highest flammability is $58 \%$ of the LFL from DST 241-SY-103 liquid waste. Ammonia is the dominant contributor to the total flammability of the vapor stream after the primary condenser under vacuum condition. The total flammability level is linearly proportional 


\section{RPP-CALC-29700 REV 1}

to the ammonia concentration of the feed liquid waste and inversely proportional to the air inleakage flow rate. 


\subsection{REFERENCES}

H-2-40704, 1975, Class II Vessel 14 Feet 0 Inch X 14 Feet 0 Inch Tank TK-386, Rev. 4, Kellex Corporation, General Electric Company, Hanford Works, Richland, Washington.

H-2-69339, 1976, Piping Arrangement Evaporator Room Plans, Rev. 2, Vista Engineering, U.S. Atomic Energy Commission, Richland Operations Office, Richland, Washington.

H-2-69340, 1977, Piping Arrangement Evaporator Room Sections, Rev. 3, Vista Engineering, U.S. Atomic Energy Commission, Richland Operations Office, Richland, Washington.

H-2-69343, 1988, Piping Arrangement Condenser Room Section, Rev. 6, Vista Engineering, U.S. Atomic Energy Commission, Richland Operations Office, Richland, Washington.

HNF-3851, 2004, Empirical Rate Equation Model and Rate Calculations of Hydrogen Generation for Hanford Tank Waste, Rev. 1, CH2M HILL Hanford Group, Inc., Richland, Washington.

HNF-14755, Documented Safety Analysis for the 242-A Evaporator, as amended, CH2M HILL Hanford Group, Inc., Richland, Washington.

HNF-14755, 2006, Documented Safety Analysis for the 242-A Evaporator, Rev. 1-C, CH2M HILL Hanford Group, Inc., Richland, Washington.

HNF-SD-WM-FHA-024, 2006, Fire Hazards Analysis for the Evaporator Facility (242-A), Rev. 3A, CH2M HILL Hanford Group, Inc., Richland, Washington.

OSD-T-151-00012, 2006, Operating Specifications for the 242-A Evaporator, Rev. 1, CH2M HILL Hanford Group, Inc., Richland, Washington.

RPP-4941, 2000, Methodology for Predicting Flammable Gas Mixtures in Double-Contained Receiver Tanks, Rev. 0-B, CH2M HILL Hanford Group, Inc., Richland, Washington.

RPP-5926, 2005, Steady-State Flammable Gas Release Rate Calculation and Lower Flammability Level Evaluation for Hanford Tank Waste, Rev. 5, CH2M HILL Hanford Group, Inc., Richland, Washington.

RPP-8050, 2005, Lower Flammability Limit Calculations for Catch Tanks, IMUSTs, DST Annuli, Pit Structures, and Double-Contained Receiver Tanks in Tank Farms at the Hanford Site, Rev. 4-A, CH2M HILL Hanford Group, Inc., Richland, Washington.

RPP-18465, 2007, Technical Basis for the 242-A Evaporator Operating Specifications, Rev. 1, CH2M HILL Hanford Group, Inc., Richland, Washington. 


\section{RPP-CALC-29700 REV 1}

RPP-21926, 2004, 242-A Evaporator Vapor Emissions Estimate Using Environmental

Simulation Program (ESP) Model, Rev. 0, CH2M HILL Hanford Group, Inc., Richland, Washington.

RPP-PLAN-23668, 2005, Process Control Plan for 242-A Evaporator Campaign 05-01, Rev. 0, CH2M HILL Hanford Group, Inc., Richland, Washington.

RPP-RPT-27963, 2005, 242-A Evaporator Campaign 05-01 Vapor Emissions Evaluation, Rev. 0, CH2M HILL Hanford Group, Inc., Richland, Washington.

TFC-ENG-CHEM-D-33, 2003, Spreadsheet Verification, Rev. B, CH2M HILL Hanford Group, Inc, Richland, Washington (Note: This instruction has been replaced by TFC-ENG-DESIGN-C-32).

TFC-ENG-DESIGN-C-32, 2005, Spreadsheet Development and Verification, Rev. 0, CH2M HILL Hanford Group, Inc, Richland, Washington (Note: Reference denotes revision used for spreadsheet verification).

Weisenberger, S., and A. Schumpe, 1996 "The Estimation of Gas Solubility in Salt Solutions at Temperatures from $273 \mathrm{~K}$ to $363 \mathrm{~K}$," AICHE Journal, Vol 42, Issue 1, pp. $298-300$.

WHC-SD-WM-PE-054, 1995, 242-A Campaign 94-2 Post Run Document, Rev. 0, Westinghouse Hanford Company, Richland, Washington.

WSRC-TR-2005-00281, 2005, Hydrogen Generation Rate Scoping Study of Dow Corning Antifoam Agent, Rev. 0, Westinghouse Savannah River Company, Aiken, South Carolina. 
RPP-CALC-29700 REV 1

\section{APPENDIX A}

INPUT DATA FOR HYDROGEN GENERATION RATES AND AMMONIA EQUILIBRIUM CALCULATIONS 
RPP-CALC-29700 REV 1

This page intentionally left blank.

A-ii 


\section{APPENDIX A}

\section{INPUT DATA FOR HYDROGEN GENERATION RATES AND AMMONIA EQUILIBRIUM CALCULATIONS}

Table A-1a. Input Data for Hydrogen Generation and Ammonia Equilibrium Model Calculations from Appendix B and C of RPP-5926, Rev. 5.

\begin{tabular}{|c|c|c|c|c|c|c|c|c|}
\hline $\begin{array}{l}\text { Supernatant } \\
\text { waste }\end{array}$ & $\begin{array}{c}\mathrm{Na} \\
\text { in liquid }^{\mathrm{a}} \\
{[\mathrm{Na}]} \\
(\mu \mathrm{g} / \mathrm{mL})\end{array}$ & $\begin{array}{c}\text { Al } \\
\text { in liquid } \\
{[\mathrm{Al}]} \\
(\mu \mathrm{g} / \mathrm{mL}) \\
\end{array}$ & $\begin{array}{c}\mathrm{Fe}^{+3} \\
\text { in liquid }^{\mathrm{b}} \\
{[\mathrm{Fe}+3]} \\
(\mu \mathrm{g} / \mathrm{mL}) \\
\end{array}$ & $\begin{array}{c}\mathrm{Cr}^{+3} \\
\text { in liquid }^{\mathrm{b}} \\
{[\mathrm{Cr}+3]} \\
(\mu \mathrm{g} / \mathrm{mL})\end{array}$ & $\begin{array}{c}\mathrm{Ni}+2 \\
\text { in liquid }^{\mathrm{b}} \\
{[\mathrm{Ni}+2]} \\
(\mu \mathrm{g} / \mathrm{mL})\end{array}$ & $\begin{array}{c}\mathbf{K}+1 \\
\text { in liquid }^{b} \\
{[\mathrm{~K}+1]} \\
(\mu \mathrm{g} / \mathbf{m L}) \\
\end{array}$ & $\begin{array}{c}\text { TOC } \\
\text { in liquid }^{\mathrm{a}} \\
\text { [TOC] } \\
(\mu \mathrm{g} / \mathrm{mL}) \\
\end{array}$ & $\begin{array}{c}\mathrm{OH}^{-1} \\
\text { in liquid } \\
{[\mathrm{OH}]} \\
(\mu \mathrm{g} / \mathrm{mL})\end{array}$ \\
\hline 241-AN-101 & $2.14 \mathrm{E}+05$ & $1.89 \mathrm{E}+04$ & $6.32 \mathrm{E}+00$ & $1.21 \mathrm{E}+02$ & $3.61 \mathrm{E}+00$ & $2.68 \mathrm{E}+03$ & $5.11 \mathrm{E}+03$ & $3.51 \mathrm{E}+04$ \\
\hline 241-AN-102 & $2.07 \mathrm{E}+05$ & $1.31 \mathrm{E}+04$ & $4.90 \mathrm{E}+01$ & $2.97 \mathrm{E}+02$ & $4.17 \mathrm{E}+02$ & $2.88 \mathrm{E}+03$ & $2.41 \mathrm{E}+04$ & $8.85 \mathrm{E}+03$ \\
\hline 241-AN-103 & $2.70 \mathrm{E}+05$ & $2.99 \mathrm{E}+04$ & $3.01 \mathrm{E}+01$ & $5.66 \mathrm{E}+02$ & $1.20 \mathrm{E}+01$ & $1.68 \mathrm{E}+04$ & $3.05 \mathrm{E}+03$ & $6.72 \mathrm{E}+04$ \\
\hline 241-AN-104 & $2.58 \mathrm{E}+05$ & $3.90 \mathrm{E}+04$ & $3.01 \mathrm{E}+01$ & $3.36 \mathrm{E}+02$ & $1.20 \mathrm{E}+01$ & $6.69 \mathrm{E}+03$ & $3.14 \mathrm{E}+03$ & $6.53 \mathrm{E}+04$ \\
\hline 241-AN-105 & $2.47 \mathrm{E}+05$ & $4.17 \mathrm{E}+04$ & $2.47 \mathrm{E}+01$ & $2.22 \mathrm{E}+02$ & $9.95 \mathrm{E}+00$ & $6.50 \mathrm{E}+03$ & $2.76 \mathrm{E}+03$ & $5.97 \mathrm{E}+04$ \\
\hline 241-AN-106 & $4.49 \mathrm{E}+04$ & $4.13 \mathrm{E}+03$ & $1.77 \mathrm{E}+00$ & $9.91 \mathrm{E}+01$ & $2.79 \mathrm{E}+02$ & $5.96 \mathrm{E}+03$ & $2.10 \mathrm{E}+03$ & $5.09 \mathrm{E}+03$ \\
\hline 241-AN-107 & $2.08 \mathrm{E}+05$ & $1.12 \mathrm{E}+03$ & $1.67 \mathrm{E}+03$ & $1.72 \mathrm{E}+02$ & $5.51 \mathrm{E}+02$ & $1.81 \mathrm{E}+03$ & $3.25 \mathrm{E}+04$ & $1.80 \mathrm{E}+04$ \\
\hline 241-AP-101 & +05 & 7.30 & $2.50 \mathrm{E}+00$ & $1.43 \mathrm{E}+02$ & $7.90 \mathrm{E}+00$ & +04 & $1.90 \mathrm{E}+03$ & $3.98 \mathrm{E}+04$ \\
\hline 241-AP-102 & $1.94 \mathrm{E}+05$ & $3.08 \mathrm{E}+04$ & $3.82 \mathrm{E}+00$ & $6.19 \mathrm{E}+02$ & 01 & +03 & +03 & $3.21 \mathrm{E}+04$ \\
\hline 241-AP-103 & $1.78 \mathrm{E}+05$ & $1.83 \mathrm{E}+04$ & $3.01 \mathrm{E}+01$ & $3.72 \mathrm{E}+02$ & $1.22 \mathrm{E}+02$ & $1.33 \mathrm{E}+04$ & $7.27 \mathrm{E}+03$ & $1.67 \mathrm{E}+04$ \\
\hline 241-AP-104 & $1.28 \mathrm{E}+05$ & $1.68 \mathrm{E}+04$ & $1.04 \mathrm{E}+02$ & $1.37 \mathrm{E}+03$ & $7.85 \mathrm{E}+01$ & $2.11 \mathrm{E}+03$ & $4.15 \mathrm{E}+03$ & $1.96 \mathrm{E}+04$ \\
\hline & & & 1 & 2 & 01 & 04 & 03 & $\mathrm{E}+04$ \\
\hline 241-AP-106 & $1.03 \mathrm{E}+05$ & $1.35 \mathrm{E}+04$ & $1.13 \mathrm{E}+02$ & +03 & $7.56 \mathrm{E}+01$ & +03 & +03 & $7.37 \mathrm{E}+03$ \\
\hline 241-AP-107 & $1.22 \mathrm{E}+05$ & $1.39 \mathrm{E}+04$ & $1.01 \mathrm{E}+01$ & $6.55 \mathrm{E}+02$ & $2.36 \mathrm{E}+00$ & $1.58 \mathrm{E}+03$ & $2.33 \mathrm{E}+03$ & $1.81 \mathrm{E}+04$ \\
\hline 241-AP-108 & $1.99 \mathrm{E}+05$ & $2.38 \mathrm{E}+04$ & $1.01 \mathrm{E}+01$ & $8.21 \mathrm{E}+02$ & $4.02 \mathrm{E}+00$ & $2.85 \mathrm{E}+03$ & $4.18 \mathrm{E}+03$ & $3.95 \mathrm{E}+04$ \\
\hline 241-AW-101 & +05 & $2.95 \mathrm{E}+04$ & $1.80 \mathrm{E}+01$ & $1.12 \mathrm{E}+02$ & $6.10 \mathrm{E}+00$ & $4.12 \mathrm{E}+04$ & $2.61 \mathrm{E}+03$ & $9.96 \mathrm{E}+04$ \\
\hline 241-AW-102 & $1.16 \mathrm{E}+05$ & $1.33 \mathrm{E}+04$ & $6.95 \mathrm{E}+00$ & $4.81 \mathrm{E}+02$ & $1.90 \mathrm{E}+00$ & $1.32 \mathrm{E}+03$ & $2.25 \mathrm{E}+03$ & $1.85 \mathrm{E}+04$ \\
\hline 241-AW-103 & $1.62 \mathrm{E}+05$ & $1.61 \mathrm{E}+04$ & $5.57 \mathrm{E}+00$ & $2.53 \mathrm{E}+01$ & $5.08 \mathrm{E}+00$ & $1.43 \mathrm{E}+04$ & $2.06 \mathrm{E}+03$ & $1.57 \mathrm{E}+04$ \\
\hline 241-AW-104 & $1.70 \mathrm{E}+05$ & $2.54 \mathrm{E}+04$ & $1.86 \mathrm{E}+00$ & $2.20 \mathrm{E}+00$ & $7.40 \mathrm{E}-01$ & $1.67 \mathrm{E}+03$ & $4.32 \mathrm{E}+03$ & $2.53 \mathrm{E}+04$ \\
\hline 241-AW-105 & $2.26 \mathrm{E}+04$ & $1.43 \mathrm{E}+02$ & $4.61 \mathrm{E}+00$ & $2.12 \mathrm{E}+00$ & $9.91 \mathrm{E}-01$ & $1.99 \mathrm{E}+03$ & $4.08 \mathrm{E}+02$ & $4.38 \mathrm{E}+03$ \\
\hline 241-AW-106 & $1.44 \mathrm{E}+05$ & $2.10 \mathrm{E}+04$ & $2.18 \mathrm{E}+01$ & $1.47 \mathrm{E}+03$ & $8.39 \mathrm{E}+00$ & $5.65 \mathrm{E}+03$ & $1.77 \mathrm{E}+03$ & $2.72 \mathrm{E}+04$ \\
\hline 241-AY-101 & $1.16 \mathrm{E}+05$ & $4.74 \mathrm{E}+03$ & $1.20 \mathrm{E}+01$ & $1.05 \mathrm{E}+02$ & $5.90 \mathrm{E}+01$ & $7.63 \mathrm{E}+02$ & $1.35 \mathrm{E}+03$ & $3.45 \mathrm{E}+04$ \\
\hline 241-AY-102 & $5.69 \mathrm{E}+04$ & $1.15 \mathrm{E}+03$ & $1.01 \mathrm{E}+01$ & $2.91 \mathrm{E}+01$ & $4.02 \mathrm{E}+00$ & $3.88 \mathrm{E}+02$ & $8.16 \mathrm{E}+02$ & $7.74 \mathrm{E}+03$ \\
\hline 241-AZ-101 & $1.12 \mathrm{E}+05$ & $6.10 \mathrm{E}+03$ & $2.24 \mathrm{E}+01$ & $7.23 \mathrm{E}+02$ & $8.02 \mathrm{E}+00$ & $4.76 \mathrm{E}+03$ & $5.14 \mathrm{E}+02$ & $1.15 E+04$ \\
\hline 241-AZ-102 & $6.15 \mathrm{E}+04$ & $3.41 \mathrm{E}+02$ & $1.00 \mathrm{E}+00$ & $7.37 \mathrm{E}+02$ & $1.75 \mathrm{E}+00$ & $3.20 \mathrm{E}+03$ & $1.99 \mathrm{E}+03$ & $2.45 \mathrm{E}+03$ \\
\hline 241-SY-101 & $1.37 \mathrm{E}+05$ & $9.45 \mathrm{E}+03$ & $3.97 \mathrm{E}+02$ & $5.18 \mathrm{E}+03$ & $2.02 \mathrm{E}+02$ & $4.14 \mathrm{E}+03$ & $2.30 \mathrm{E}+03$ & $3.74 \mathrm{E}+04$ \\
\hline 241-SY-102 & $1.22 \mathrm{E}+05$ & $8.41 \mathrm{E}+03$ & $1.41 \mathrm{E}+01$ & $2.41 \mathrm{E}+02$ & $5.04 \mathrm{E}+01$ & $1.53 \mathrm{E}+03$ & $1.24 \mathrm{E}+03$ & $9.64 \mathrm{E}+03$ \\
\hline 241-SY-103 & $2.15 \mathrm{E}+05$ & $3.76 \mathrm{E}+04$ & $2.10 \mathrm{E}+01$ & $3.30 \mathrm{E}+01$ & $4.90 \mathrm{E}+01$ & $3.91 \mathrm{E}+03$ & $6.22 \mathrm{E}+03$ & $2.99 \mathrm{E}+04$ \\
\hline
\end{tabular}

Notes:

${ }^{a}$ Input data were taken from Appendix B (hydrogen generation rate input data), which was from the Best-Basis Inventory data download on September 27, 2005.

${ }^{b}$ Input data were taken from Appendix C (ammonia input data), which was prepared in 2001.

RPP-5926, 2005, Steady-State Flammable Gas Release Rate Calculation and Lower Flammability Level Evaluation for Hanford Tank Waste, Rev. 5, CH2M HILL Hanford Group, Inc., Richland, Washington. 
Table A-1b. Input Data for Hydrogen Generation and Ammonia Equilibrium Model Calculations from Appendix B and C of RPP-5926, Rev. 5.

\begin{tabular}{|c|c|c|c|c|c|c|c|}
\hline $\begin{array}{l}\text { Supernatant } \\
\text { waste }\end{array}$ & $\begin{array}{c}\mathrm{NO}_{2} \\
\text { in liquid }^{\mathrm{a}} \\
{\left[\mathrm{NO}_{2}\right]} \\
(\mu \mathrm{g} / \mathrm{mL}) \\
\end{array}$ & $\begin{array}{c}\mathrm{NO}_{3} \\
\text { in liquid } \\
{\left[\mathrm{NO}_{3}\right]} \\
(\mu \mathrm{g} / \mathrm{mL}) \\
\end{array}$ & $\begin{array}{c}\mathrm{CO}_{3}^{-2} \\
\text { in liquid } \\
{\left[\mathrm{CO}_{3}^{-2}\right]} \\
(\mu \mathrm{g} / \mathrm{mL}) \\
\end{array}$ & $\begin{array}{c}\mathrm{PO}_{4}^{-3} \\
\text { in liquid } \\
{\left[\mathrm{PO}_{4}^{-3}\right]} \\
(\mu \mathrm{g} / \mathrm{mL}) \\
\end{array}$ & $\begin{array}{c}\mathrm{SO}_{4}^{-2} \\
\text { in liquid } \\
{\left[\mathrm{SO}_{4}^{-2}\right]} \\
(\mu \mathrm{g} / \mathrm{mL}) \\
\end{array}$ & $\begin{array}{c}\mathbf{F}^{-1} \\
\text { in liquid } \\
{\left[F^{-1}\right]} \\
(\mu \mathrm{g} / \mathrm{mL})\end{array}$ & $\begin{array}{c}\mathrm{Cl}^{-1} \\
\text { in liquid }^{\mathrm{b}} \\
{\left[\mathrm{Cl}^{-1}\right]} \\
(\mu \mathrm{g} / \mathrm{mL}) \\
\end{array}$ \\
\hline 241 & $16 \mathrm{E}+05$ & $1.62 \mathrm{E}+05$ & $9.65 \mathrm{E}+03$ & $1.59 \mathrm{E}+03$ & $1.36 \mathrm{E}+03$ & $2.89 \mathrm{E}+02$ & $2.33 E+03$ \\
\hline 241-AN-102 & $71 \mathrm{E}+04$ & $2.09 \mathrm{E}+05$ & $7.00 \mathrm{E}+04$ & $5.52 \mathrm{E}+03$ & $1.53 \mathrm{E}+04$ & $1.91 \mathrm{E}+03$ & $4.11 E+03$ \\
\hline 241-AN-103 & $1.30 \mathrm{E}+05$ & $1.29 \mathrm{E}+05$ & $5.80 \mathrm{E}+03$ & $1.65 \mathrm{E}+03$ & $1.45 \mathrm{E}+03$ & $6.60 \mathrm{E}+02$ & $9.76 \mathrm{E}+03$ \\
\hline 241-AN-104 & $1.19 \mathrm{E}+05$ & $1.89 \mathrm{E}+05$ & $1.07 \mathrm{E}+04$ & $2.71 \mathrm{E}+03$ & $3.54 \mathrm{E}+03$ & $8.19 \mathrm{E}+01$ & $8.09 \mathrm{E}+03$ \\
\hline 241-AN-105 & $1.19 \mathrm{E}+05$ & $1.56 \mathrm{E}+05$ & $1.18 \mathrm{E}+04$ & $1.22 \mathrm{E}+03$ & $2.85 \mathrm{E}+03$ & $3.06 \mathrm{E}+02$ & $9.90 \mathrm{E}+03$ \\
\hline 241-AN-106 & $01 \mathrm{E}+04$ & $2.53 \mathrm{E}+04$ & $2.18 \mathrm{E}+04$ & $2.02 \mathrm{E}+03$ & $5.50 \mathrm{E}+03$ & $5.11 \mathrm{E}+03$ & $9.60 \mathrm{E}+02$ \\
\hline 241-AN-107 & $.67 \mathrm{E}+04$ & $2.09 \mathrm{E}+05$ & $7.55 \mathrm{E}+04$ & $2.94 \mathrm{E}+03$ & $8.98 \mathrm{E}+03$ & $4.18 \mathrm{E}+03$ & $2.02 \mathrm{E}+03$ \\
\hline $241-A$ & $4.08 \mathrm{E}+04$ & $1.18 \mathrm{E}+05$ & $3.23 \mathrm{E}+04$ & $1.02 \mathrm{E}+03$ & $4.03 E+03$ & $2.90 \mathrm{E}+03$ & $1.98 \mathrm{E}+03$ \\
\hline $241-$ & 04 & 1.67 & $2.66 \mathrm{E}+04$ & $1.16 \mathrm{E}+04$ & $4.52 \mathrm{E}+03$ & $1.68 \mathrm{E}+02$ & $2.73 \mathrm{E}+03$ \\
\hline 241-A & -04 & 1.49 & $7.55 \mathrm{E}+04$ & $3.46 \mathrm{E}+03$ & $4.50 \mathrm{E}+03$ & $2.09 \mathrm{E}+03$ & $2.82 \mathrm{E}+03$ \\
\hline $241-$ & $6.39 \mathrm{E}+04$ & $1.01 \mathrm{E}+05$ & $1.93 \mathrm{E}+04$ & $3.86 \mathrm{E}+03$ & $3.84 \mathrm{E}+03$ & $4.15 \mathrm{E}+02$ & $9 \mathrm{E}+03$ \\
\hline $241-$ & +04 & 1.06 & +05 & $3.16 \mathrm{E}+03$ & $6.78 \mathrm{E}+03$ & +03 & $45 \mathrm{E}+03$ \\
\hline $241-$ & 04 & 7.07 & 1.88 & $2.76 \mathrm{E}+03$ & $3.20 \mathrm{E}+03$ & 6.71 & $2 \mathrm{E}+03$ \\
\hline $241-$ & $5.14 \mathrm{E}+04$ & $1.12 \mathrm{E}+05$ & $4.55 \mathrm{E}+03$ & $\mathrm{E}+03$ & $2.41 \mathrm{E}+03$ & $7.22 \mathrm{E}+02$ & $29 \mathrm{E}+03$ \\
\hline 241 & $2 \mathrm{E}+04$ & 1.76 & $7 \mathrm{E}+04$ & -03 & $2 \mathrm{E}+03$ & $9.70 \mathrm{E}+02$ & $2.86 \mathrm{E}+03$ \\
\hline 241-AI & $1.05 \mathrm{E}+05$ & $1.71 E+05$ & $9.20 \mathrm{E}+03$ & $9.96 \mathrm{E}+02$ & $1.26 \mathrm{E}+03$ & $9.62 \mathrm{E}+02$ & $7.30 \mathrm{E}+03$ \\
\hline 241-AW-102 & $4.87 \mathrm{E}+04$ & $1.06 \mathrm{E}+05$ & $2.31 \mathrm{E}+03$ & $6.22 \mathrm{E}+02$ & $1.72 \mathrm{E}+03$ & $5.42 \mathrm{E}+02$ & $1.68 \mathrm{E}+03$ \\
\hline 241-AW-103 & $4.30 \mathrm{E}+04$ & $1.31 \mathrm{E}+05$ & $4.70 \mathrm{E}+03$ & $5.92 \mathrm{E}+01$ & $6.72 \mathrm{E}+02$ & $1.68 \mathrm{E}+04$ & $1.38 \mathrm{E}+02$ \\
\hline 241-AW-104 & $7.45 E+04$ & $1.12 \mathrm{E}+05$ & $7.25 \mathrm{E}+03$ & $2.93 \mathrm{E}+02$ & $6.54 \mathrm{E}+02$ & $1.32 \mathrm{E}+02$ & $2.39 \mathrm{E}+02$ \\
\hline 241-AW-105 & $2.55 \mathrm{E}+03$ & $2.46 \mathrm{E}+04$ & $1.62 \mathrm{E}+03$ & $1.85 \mathrm{E}+02$ & $3.01 \mathrm{E}+02$ & $4.81 E+02$ & $2.45 E+02$ \\
\hline 241-AW-106 & $5.49 \mathrm{E}+04$ & $1.14 \mathrm{E}+05$ & $2.84 \mathrm{E}+04$ & $1.47 \mathrm{E}+03$ & $5.14 \mathrm{E}+03$ & $1.23 \mathrm{E}+03$ & $5.17 \mathrm{E}+03$ \\
\hline 241-AY-101 & $3.35 \mathrm{E}+04$ & $4.65 \mathrm{E}+03$ & $3.44 \mathrm{E}+04$ & $1.15 \mathrm{E}+03$ & $5.87 \mathrm{E}+03$ & $1.74 \mathrm{E}+02$ & $6.36 \mathrm{E}+02$ \\
\hline 241-AY-102 & $2.99 \mathrm{E}+04$ & $3.91 \mathrm{E}+02$ & $4.87 \mathrm{E}+04$ & $3.01 \mathrm{E}+03$ & $2.32 \mathrm{E}+03$ & $1.72 \mathrm{E}+02$ & $1.60 \mathrm{E}+02$ \\
\hline 241-AZ-101 & $6.20 \mathrm{E}+04$ & $5.32 \mathrm{E}+04$ & $3.42 \mathrm{E}+04$ & $1.34 \mathrm{E}+03$ & $1.50 \mathrm{E}+04$ & $1.75 E+03$ & $1.51 E+02$ \\
\hline 241-AZ-102 & $4.07 \mathrm{E}+04$ & $8.23 \mathrm{E}+03$ & $3.50 \mathrm{E}+04$ & $4.97 \mathrm{E}+02$ & $1.86 \mathrm{E}+04$ & $1.14 \mathrm{E}+03$ & $7.66 \mathrm{E}+01$ \\
\hline 241-SY-101 & $4.14 \mathrm{E}+04$ & $1.03 \mathrm{E}+05$ & $3.44 \mathrm{E}+04$ & $4.94 \mathrm{E}+03$ & $4.19 E+03$ & $5.50 \mathrm{E}+02$ & $1.11 \mathrm{E}+04$ \\
\hline 241-SY-102 & $2.45 E+04$ & $1.65 \mathrm{E}+05$ & $1.31 \mathrm{E}+04$ & $3.48 \mathrm{E}+03$ & $2.91 \mathrm{E}+03$ & $1.51 \mathrm{E}+02$ & $4.64 \mathrm{E}+03$ \\
\hline 241-SY-103 & $1.52 \mathrm{E}+05$ & $1.68 \mathrm{E}+05$ & $3.44 \mathrm{E}+04$ & $3.12 \mathrm{E}+03$ & $4.08 \mathrm{E}+03$ & $3.51 \mathrm{E}+02$ & $1.16 \mathrm{E}+04$ \\
\hline
\end{tabular}

Notes:

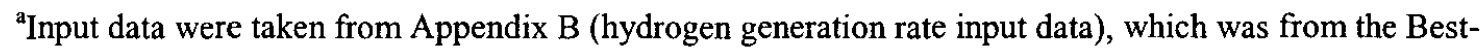
Basis Inventory data download on September 27, 2005.

'Input data were taken from Appendix C (ammonia input data), which was prepared in 2001.

RPP-5926, 2005, Steady-State Flammable Gas Release Rate Calculation and Lower Flammability Level Evaluation for Hanford Tank Waste, Rev. 5, CH2M HILL Hanford Group, Inc., Richland, Washington. 
Table A-1c. Input Data for Hydrogen Generation and Ammonia Equilibrium Model Calculations from Appendix B and C of RPP-5926, Rev. 5.

\begin{tabular}{|c|c|c|c|c|c|c|c|c|}
\hline $\begin{array}{l}\text { Supernatant } \\
\text { waste }\end{array}$ & $\begin{array}{c}{ }^{90} \mathrm{Sr} \\
\text { in waste } \\
{[\mathrm{Sr}]} \\
(\mu \mathrm{Ci} / \mathrm{g})\end{array}$ & $\begin{array}{c}{ }^{241} \mathrm{Am} \\
\text { in waste }{ }^{\mathrm{a}} \\
{[\mathrm{Am} 241]} \\
(\mu \mathrm{Ci} / \mathrm{g})\end{array}$ & $\begin{array}{c}{ }^{240} \mathrm{Pu} \\
\text { in waste } \\
{[\mathrm{Pu} 240]} \\
(\mu \mathrm{Ci} / \mathrm{g})\end{array}$ & $\begin{array}{c}{ }^{239} \mathrm{Pu} \\
\text { in waste }{ }^{a} \\
{[\mathrm{Pu} 240]} \\
(\mu \mathrm{Ci} / \mathrm{g})\end{array}$ & $\begin{array}{c}{ }^{238} \mathrm{Pu} \\
\text { in waste } \\
{[\mathrm{Pu} 238]} \\
(\mu \mathrm{Ci} / \mathrm{g})\end{array}$ & $\begin{array}{c}{ }^{137} \mathrm{Cs} \\
\text { in waste } \\
{[\mathrm{Cs}]} \\
(\mu \mathrm{Ci} / \mathrm{g})\end{array}$ & $\begin{array}{c}\left(\mathrm{NH}_{3}\right)_{s s} \\
\text { in dome }^{\mathrm{b}} \\
(\mathrm{ppm})\end{array}$ & $\begin{array}{c}\text { Liquid } \\
\mathrm{NH}_{3}{ }^{\mathrm{b}} \\
(\mu \mathrm{g} / \mathrm{mL})\end{array}$ \\
\hline 241-AN-101 & $1.27 \mathrm{E}+00$ & $6.57 \mathrm{E}-04$ & $1.03 \mathrm{E}-05$ & $6.21 \mathrm{E}-05$ & $1.54 \mathrm{E}-06$ & $1.98 \mathrm{E}+02$ & $1.13 \mathrm{E}+01$ & $1.68 \mathrm{E}+02$ \\
\hline 241-AN-102 & $5.60 \mathrm{E}+01$ & $1.15 \mathrm{E}-01$ & $8.77 \mathrm{E}-04$ & $3.37 \mathrm{E}-03$ & $2.45 \mathrm{E}-04$ & $2.78 \mathrm{E}+02$ & $3.00 \mathrm{E}+02$ & $2.10 \mathrm{E}+02$ \\
\hline 241-AN-103 & $1.19 \mathrm{E}-02$ & $4.11 \mathrm{E}-03$ & 4.47E-05 & $1.72 \mathrm{E}-04$ & $1.25 \mathrm{E}-05$ & $4.25 \mathrm{E}+02$ & $6.65 \mathrm{E}+00$ & $3.45 \mathrm{E}+02$ \\
\hline 241-AN-104 & $5.84 \mathrm{E}-02$ & $2.51 \mathrm{E}-04$ & $1.34 \mathrm{E}-05$ & $5.16 \mathrm{E}-05$ & $3.73 \mathrm{E}-06$ & $3.51 \mathrm{E}+02$ & $2.10 \mathrm{E}+01$ & $2.46 \mathrm{E}+02$ \\
\hline 241 & $2.44 \mathrm{E}-02$ & $1.01 \mathrm{E}-02$ & $1.10 \mathrm{E}-04$ & $4.24 \mathrm{E}-04$ & $3.07 \mathrm{E}-05$ & $2.06 \mathrm{E}+02$ & $1.51 \mathrm{E}+01$ & $2.10 \mathrm{E}+02$ \\
\hline 241 & $72 \mathrm{E}-01$ & $4.18 \mathrm{E}-04$ & $4.72 \mathrm{E}-04$ & $3.05 \mathrm{E}-03$ & $4.83 \mathrm{E}-05$ & $4.66 \mathrm{E}+01$ & +00 & $2.10 \mathrm{E}+02$ \\
\hline 241-AN-107 & $5.37 \mathrm{E}+01$ & $5.11 \mathrm{E}-01$ & $8.21 \mathrm{E}-03$ & $3.16 \mathrm{E}-02$ & $2.29 \mathrm{E}-03$ & $2.09 \mathrm{E}+02$ & $4.00 \mathrm{E}+02$ & $2.10 \mathrm{E}+02$ \\
\hline 241-AP-101 & $7.51 \mathrm{E}-02$ & $1.48 \mathrm{E}-04$ & $2.10 \mathrm{E}-05$ & $8.06 \mathrm{E}-05$ & $5.85 \mathrm{E}-06$ & $1.07 \mathrm{E}+02$ & $1.25 \mathrm{E}+02$ & $4.39 \mathrm{E}+02$ \\
\hline 241-AP-102 & $2.77 \mathrm{E}-01$ & $1.24 \mathrm{E}-03$ & $3.75 \mathrm{E}-05$ & $2.22 \mathrm{E}-04$ & $5.75 \mathrm{E}-06$ & $1.72 \mathrm{E}+02$ & $7.52 \mathrm{E}+01$ & $4.39 \mathrm{E}+02$ \\
\hline 241 & $1.78 \mathrm{E}+00$ & 03 & 1.16 & $6.91 \mathrm{E}-04$ & $2.14 \mathrm{E}-05$ & $1.70 \mathrm{E}+02$ & $1.00 \mathrm{E}+00$ & $2.50 \mathrm{E}+02$ \\
\hline 241 & $1.30 \mathrm{E}+00$ & 1.8 & 1.9 & $1.17 \mathrm{E}-03$ & $3.10 \mathrm{E}-05$ & $1.45 \mathrm{E}+02$ & $3.14 \mathrm{E}+00$ & $1.33 \mathrm{E}+02$ \\
\hline 241 & $2.14 \mathrm{E}-01$ & 5.45 & $3.65 \mathrm{E}-05$ & 2.22 & 05 & $1.07 \mathrm{E}+02$ & $7.33 \mathrm{E}+00$ & $3.24 \mathrm{E}+02$ \\
\hline 24 & $9.84 \mathrm{E}-01$ & 5.02 & 1.05 & 55 & 6 & 1.4 & $5.33 E+00$ & $6.75 \mathrm{E}+01$ \\
\hline 24 & 7.85 & 4. & 9. & 5 & 1.3 & -02 & $E+00$ & $4 \mathrm{E}+03$ \\
\hline 241-AP-108 & $5.01 \mathrm{E}-01$ & $2.34 \mathrm{E}-04$ & $4.66 \mathrm{E}-05$ & $2.30 \mathrm{E}-04$ & $1.71 \mathrm{E}-05$ & $1.40 \mathrm{E}+02$ & $2.66 \mathrm{E}+01$ & $9.63 \mathrm{E}+02$ \\
\hline 241-AW-101 & $2.55 \mathrm{E}-01$ & 1. & 7.27 & 4 & 5 & $2.58 \mathrm{E}+02$ & $5.15 \mathrm{E}+00$ & $1.00 \mathrm{E}+01$ \\
\hline 24 & 1 & 3 & 1.3 & 55 & 6 & $9.91 \mathrm{E}+01$ & $2.55 \mathrm{E}+00$ & $7.43 \mathrm{E}+01$ \\
\hline $241-\mathrm{A}$ & 1.77E-01 & 05 & $2.04 \mathrm{E}-05$ & $9.58 \mathrm{E}-05$ & $8.66 \mathrm{E}-06$ & $9.01 \mathrm{E}+01$ & $1.38 \mathrm{E}+02$ & $5.12 \mathrm{E}+02$ \\
\hline 241-AW-104 & $1.21 \mathrm{E}+00$ & $1.16 \mathrm{E}-03$ & $1.88 \mathrm{E}-05$ & $1.05 \mathrm{E}-04$ & $3.36 \mathrm{E}-06$ & $1.77 \mathrm{E}+02$ & $6.00 \mathrm{E}+00$ & $1.69 \mathrm{E}+02$ \\
\hline 241-AW-105 & $2.08 \mathrm{E}-02$ & $6.03 \mathrm{E}-05$ & $6.09 \mathrm{E}-05$ & $2.16 \mathrm{E}-04$ & $2.15 \mathrm{E}-05$ & $9.42 \mathrm{E}+00$ & $4.28 \mathrm{E}+01$ & $1.01 \mathrm{E}+03$ \\
\hline 241-AW-106 & $3.56 \mathrm{E}-01$ & $5.80 \mathrm{E}-04$ & $2.87 \mathrm{E}-05$ & $1.82 \mathrm{E}-04$ & $3.82 \mathrm{E}-06$ & $1.19 \mathrm{E}+02$ & $2.78 \mathrm{E}+01$ & $3.55 \mathrm{E}+02$ \\
\hline 241-AY-101 & $7.81 \mathrm{E}-01$ & $2.22 \mathrm{E}-03$ & $3.36 \mathrm{E}-03$ & $1.44 \mathrm{E}-02$ & $6.00 \mathrm{E}-04$ & $3.90 \mathrm{E}+01$ & $5.00 \mathrm{E}+00$ & $1.13 \mathrm{E}+02$ \\
\hline 241-AY-102 & $9.65 \mathrm{E}-01$ & $1.79 \mathrm{E}-04$ & $2.91 \mathrm{E}-04$ & $1.34 \mathrm{E}-03$ & $2.16 \mathrm{E}-04$ & $1.71 \mathrm{E}+01$ & $4.29 \mathrm{E}+00$ & $7.37 \mathrm{E}+01$ \\
\hline 241-AZ-101 & $7.06 \mathrm{E}-01$ & $1.17 \mathrm{E}-04$ & $3.26 \mathrm{E}-04$ & $1.14 \mathrm{E}-03$ & $1.18 \mathrm{E}-04$ & $1.27 \mathrm{E}+03$ & $1.00 \mathrm{E}+00$ & $1.25 \mathrm{E}+02$ \\
\hline 241-AZ-102 & $1.77 \mathrm{E}+00$ & $5.62 \mathrm{E}-04$ & $1.80 \mathrm{E}-03$ & $6.57 \mathrm{E}-03$ & $6.36 \mathrm{E}-04$ & $8.50 \mathrm{E}+02$ & $5.53 \mathrm{E}+00$ & $4.38 \mathrm{E}+02$ \\
\hline 241-SY-101 & $1.69 \mathrm{E}+00$ & 4.37E-04 & $1.76 \mathrm{E}-05$ & $1.11 \mathrm{E}-04$ & $2.36 \mathrm{E}-06$ & $9.07 \mathrm{E}+01$ & $4.00 \mathrm{E}+02$ & $1.04 \mathrm{E}+03$ \\
\hline 241-SY-102 & $9.28 \mathrm{E}-02$ & $2.96 \mathrm{E}-04$ & $1.36 \mathrm{E}-05$ & 8.29E-05 & $1.99 \mathrm{E}-06$ & $5.97 \mathrm{E}+01$ & $1.17 \mathrm{E}+01$ & $1.15 \mathrm{E}+03$ \\
\hline 241-SY-103 & $2.05 \mathrm{E}+00$ & $6.92 \mathrm{E}-03$ & $7.97 \mathrm{E}-06$ & $3.71 \mathrm{E}-05$ & $1.30 \mathrm{E}-06$ & $2.92 \mathrm{E}+02$ & $5.94 \mathrm{E}+01$ & $1.29 \mathrm{E}+03$ \\
\hline
\end{tabular}

Notes:

${ }^{a}$ Input data were taken from Appendix B (hydrogen generation rate input data), which was from the Best-Basis Inventory data download on September 27, 2005.

binput data were taken from Appendix C (ammonia input data), which was prepared in 2001.

RPP-5926, 2005, Steady-State Flammable Gas Release Rate Calculation and Lower Flammability Level Evaluation for Hanford Tank Waste, Rev. 5, CH2M HILL Hanford Group, Inc., Richland, Washington. 
Table A-1d. Input Data for Hydrogen Generation and Ammonia Equilibrium Model Calculations from Appendix B and C of RPP-5926, Rev. 5.

\begin{tabular}{|c|c|c|c|c|c|c|c|c|}
\hline $\begin{array}{l}\text { Supernatant } \\
\text { waste }\end{array}$ & $\begin{array}{c}\text { Bulk } \\
\text { density } \\
\text { D } \\
(\mathrm{g} / \mathrm{mL}) \\
\end{array}$ & $\begin{array}{c}\text { Liquid } \\
\text { density } \\
\text { DL } \\
(\mathrm{g} / \mathrm{ml}) \\
\end{array}$ & $\begin{array}{c}\text { Waste }^{\mathrm{b}} \\
\text { volume } \\
(\mathrm{kL})\end{array}$ & $\begin{array}{c}\text { Bulk } \\
\text { water } \\
{[\mathrm{H} 2 \mathrm{O}]} \\
(\mathrm{wt} \%) \\
\end{array}$ & $\begin{array}{r}\text { Liquid } \\
\text { water } \\
{[\mathrm{H} 20]} \\
(\mathbf{w t} \%) \\
\end{array}$ & $\begin{array}{c}\text { Waste } \\
\text { temp. } \\
\text { Tw } \\
\left({ }^{\circ} \mathbf{C}\right) \\
\end{array}$ & $\begin{array}{c}\text { Dome } \\
\text { temp. } \\
\text { Td } \\
\left({ }^{\circ} \mathrm{C}\right) \\
\end{array}$ & $\begin{array}{c}\text { Headspace } \\
\text { volume } \\
\left(\mathbf{f t t}^{\mathbf{b}}\right)\end{array}$ \\
\hline 241-AN-101 & 1.41 & 1.41 & 98 & $52 \%$ & $52 \%$ & 27 & 25 & 2,135 \\
\hline 241-AN-102 & 1.41 & 1.41 & 98 & $43 \%$ & $43 \%$ & 32 & 31 & 2,135 \\
\hline 241-AN-103 & 1.48 & 1.48 & 98 & $47 \%$ & $47 \%$ & 38 & 32 & 2,135 \\
\hline 241-AN-104 & 1.40 & 1.40 & 98 & $51 \%$ & $51 \%$ & 35 & 32 & 2,135 \\
\hline 241-AN-105 & 1.42 & 1.42 & 98 & $50 \%$ & $50 \%$ & 32 & 30 & 2,135 \\
\hline 241-AN-106 & 1.11 & 1.11 & 98 & $82 \%$ & $82 \%$ & 24 & 22 & 2,135 \\
\hline 241-AN-107 & 1.43 & 1.43 & 98 & $52 \%$ & $52 \%$ & 33 & 31 & 2,135 \\
\hline 241-AP-101 & 1.30 & 1.30 & 98 & $64 \%$ & $64 \%$ & 21 & 22 & 2,135 \\
\hline 241-AP-102 & 1.39 & 1.39 & 98 & $59 \%$ & $59 \%$ & 21 & 19 & 2,135 \\
\hline 241-AP-103 & 1.35 & 1.35 & 98 & $57 \%$ & $57 \%$ & 21 & 23 & 2,135 \\
\hline 241-AP-104 & 1.28 & 1.28 & 98 & $66 \%$ & $66 \%$ & 23 & 22 & 2,135 \\
\hline 241-AP-105 & 1.27 & 1.27 & 98 & $71 \%$ & $71 \%$ & 19 & 18 & 2,135 \\
\hline 241-AP-106 & 1.21 & 1.21 & 98 & $72 \%$ & $72 \%$ & 24 & 19 & 2,135 \\
\hline 241-AP-107 & 1.28 & 1.28 & 98 & $66 \%$ & $66 \%$ & 20 & 19 & 2,135 \\
\hline 241-AP-108 & 1.43 & 1.43 & 98 & $53 \%$ & $53 \%$ & 32 & 41 & 2,135 \\
\hline 241-AW-101 & 1.47 & 1.47 & 98 & $44 \%$ & $44 \%$ & 32 & 21 & 2,135 \\
\hline 241-AW-102 & 1.26 & 1.26 & 98 & $67 \%$ & $67 \%$ & 22 & 22 & 2,135 \\
\hline 241-AW-103 & 1.24 & 1.24 & 98 & $66 \%$ & $66 \%$ & 21 & 21 & 2,135 \\
\hline 241-AW-104 & 1.35 & 1.35 & 98 & $55 \%$ & $67 \%$ & 28 & 25 & 2,135 \\
\hline 241-AW-105 & 1.06 & 1.06 & 98 & $90 \%$ & $90 \%$ & 19 & 20 & 2,135 \\
\hline 241-AW-106 & 1.30 & 1.30 & 98 & $72 \%$ & $72 \%$ & 26 & 25 & 2,135 \\
\hline 241-AY-101 & 1.19 & 1.19 & 98 & $80 \%$ & $80 \%$ & 42 & 34 & 2,135 \\
\hline 241-AY-102 & 1.17 & 1.17 & 98 & $83 \%$ & $83 \%$ & 49 & 40 & 2,135 \\
\hline 241-AZ-101 & 1.24 & 1.24 & 98 & $73 \%$ & $73 \%$ & 72 & 72 & 2,135 \\
\hline 241-AZ-102 & 1.11 & 1.11 & 98 & $83 \%$ & $83 \%$ & 49 & 49 & 2,135 \\
\hline 241-SY-101 & 1.30 & 1.30 & 98 & $65 \%$ & $65 \%$ & 23 & 20 & 2,135 \\
\hline 241-SY-102 & 1.27 & 1.27 & 98 & $65 \%$ & $65 \%$ & 26 & 26 & 2,135 \\
\hline 241-SY-103 & 1.47 & 1.47 & 98 & $43 \%$ & $43 \%$ & 28 & 25 & 2,135 \\
\hline
\end{tabular}

Notes:

${ }^{a}$ RPP-5926, 2005, Steady-State Flammable Gas Release Rate Calculation and Lower Flammability Level

Evaluation for Hanford Tank Waste, Rev. 5, CH2M HILL Hanford Group, Inc., Richland, Washington.

${ }^{\mathrm{b}}$ These values are for evaporator vessel C-A-1.

RGS = retained gas sampler. 
Table A-2. Updated Ammonia Liquid Data Based on TWINS Database.

\begin{tabular}{|c|c|c|c|}
\hline Tanks & $\begin{array}{c}\text { RPP-5926 } \mathrm{NH}_{3} \\
\text { prepared in } 1999 \\
(\mu \mathrm{g} / \mathrm{mL}) \\
\end{array}$ & $\begin{array}{c}\text { Maximum } \\
\text { supernatant } \mathrm{NH}_{3} \\
\text { after } 1999^{*}(\mu \mathrm{g} / \mathrm{mL})\end{array}$ & $\begin{array}{c}\mathrm{NH}_{3} \text { used in this } \\
\text { calculation }(\mu \mathrm{g} / \mathrm{mL})\end{array}$ \\
\hline 241-AN-101 & $4.00 \mathrm{E}+01$ & $1.68 \mathrm{E}+02$ & $1.68 \mathrm{E}+02$ \\
\hline 241-AN-102 & $2.10 \mathrm{E}+02$ & NA & $2.10 \mathrm{E}+02$ \\
\hline 241-AN-103 & $3.45 \mathrm{E}+02$ & $\mathrm{NA}$ & $3.45 \mathrm{E}+02$ \\
\hline 241-AN-104 & $2.46 \mathrm{E}+02$ & NA & $2.46 \mathrm{E}+02$ \\
\hline 241-AN-105 & $2.10 \mathrm{E}+02$ & NA & $2.10 \mathrm{E}+02$ \\
\hline $241-\mathrm{AN}-106$ & $2.10 \mathrm{E}+02$ & $1.01 \mathrm{E}+02$ & $2.10 \mathrm{E}+02$ \\
\hline 241-AN-107 & $2.10 \mathrm{E}+02$ & $\mathrm{NA}$ & $2.10 \mathrm{E}+02$ \\
\hline 241-AP-101 & $4.39 \mathrm{E}+02$ & $1.13 E+02$ & $4.39 E+02$ \\
\hline 241-AP-102 & $4.39 \mathrm{E}+02$ & $\mathrm{NA}$ & $4.39 \mathrm{E}+02$ \\
\hline 241-AP-103 & $2.50 \mathrm{E}+02$ & NA & $2.50 \mathrm{E}+02$ \\
\hline 241-AP-104 & $1.33 \mathrm{E}+02$ & $\mathrm{NA}$ & $1.33 \mathrm{E}+02$ \\
\hline 241-AP-105 & $3.24 \mathrm{E}+02$ & $\mathrm{NA}$ & $3.24 \mathrm{E}+02$ \\
\hline 241-AP-106 & $6.75 \mathrm{E}+01$ & $\mathrm{NA}$ & $6.75 \mathrm{E}+01$ \\
\hline 241-AP-107 & $1.06 \mathrm{E}+03$ & $1.14 \mathrm{E}+03$ & $1.14 E+03$ \\
\hline 241-AP-108 & $8.00 \mathrm{E}+02$ & $9.63 E+02$ & $9.63 E+02$ \\
\hline 241-AW-101 & $1.00 \mathrm{E}+01$ & $\mathrm{NA}$ & $1.00 \mathrm{E}+01$ \\
\hline 241-AW-102 & $7.43 \mathrm{E}+01$ & $\mathrm{NA}$ & $7.43 \mathrm{E}+01$ \\
\hline 241-AW-103 & $5.12 \mathrm{E}+02$ & $\mathrm{NA}$ & $5.12 \mathrm{E}+02$ \\
\hline 241-AW-104 & $1.69 \mathrm{E}+02$ & $8.03 E+01$ & $1.69 E+02$ \\
\hline 241-AW-105 & $1.01 \mathrm{E}+03$ & $\mathrm{NA}$ & $1.01 \mathrm{E}+03$ \\
\hline 241-AW-106 & $3.55 \mathrm{E}+02$ & $1.11 \mathrm{E}+02$ & $3.55 \mathrm{E}+02$ \\
\hline 241-AY-101 & $1.13 \mathrm{E}+02$ & $\mathrm{NA}$ & $1.13 \mathrm{E}+02$ \\
\hline 241-AY-102 & $7.37 \mathrm{E}+01$ & $\mathrm{NA}$ & $7.37 \mathrm{E}+01$ \\
\hline 241-AZ-101 & $1.25 \mathrm{E}+02$ & $\mathrm{NA}$ & $1.25 \mathrm{E}+02$ \\
\hline 241-AZ-102 & $4.38 \mathrm{E}+02$ & $\mathrm{NA}$ & $4.38 \mathrm{E}+02$ \\
\hline 241-SY-101 & $1.04 \mathrm{E}+03$ & $\mathrm{NA}$ & $1.04 \mathrm{E}+03$ \\
\hline 241-SY-102 & $1.15 \mathrm{E}+03$ & $1.15 \mathrm{E}+03$ & $1.15 \mathrm{E}+03$ \\
\hline $241-S Y-103$ & $1.29 \mathrm{E}+03$ & $\mathrm{NA}$ & $1.29 \mathrm{E}+03$ \\
\hline
\end{tabular}

Notes:

*Data compiled from TWINs database updated May 2006.

RPP-5926, 2005, Steady-State Flammable Gas Release Rate Calculation and Lower

Flammability Level Evaluation for Hanford Tank Waste, Rev. 5, CH2M HILL Hanford Group, Inc., Richland, Washington.

TWINS, Best Basis Inventory, available at http://twins.pnl.gov/twins.htm, Pacific Northwest National Laboratory, Richland, Washington.

NA $=$ not applicable. 


\section{RPP-CALC-29700 REV 1}

Table A-3a. Concentrated Input Data for Hydrogen Generation and Ammonia Equilibrium Model Calculations at Target SpG of 1.6.

\begin{tabular}{|c|c|c|c|c|c|c|c|c|}
\hline $\begin{array}{r}\text { Super } \\
\text { wa }\end{array}$ & $\begin{array}{c}\text { Concen. } \\
\text { ratio } \\
\text { for final } \\
\text { density } \\
\text { is } 1.6 \\
\left(V_{0} / V\right) \\
\end{array}$ & $\begin{array}{c}\mathrm{Na} \\
\text { in liquid } \\
{[\mathrm{Na}]} \\
(\mu \mathrm{g} / \mathrm{mL})\end{array}$ & $\begin{array}{c}\text { Al } \\
\text { in liquid } \\
\text { [Al] } \\
(\mu \mathrm{g} / \mathbf{m L})\end{array}$ & $\begin{array}{c}\mathrm{Fe}+3 \\
\text { in liquid } \\
{[\mathrm{Fe}+3]} \\
(\mu \mathrm{g} / \mathrm{mL})\end{array}$ & $\begin{array}{c}\mathrm{Cr}+3 \\
\text { in liquid } \\
{[\mathrm{Cr}+3]} \\
(\mu \mathrm{g} / \mathrm{mL})\end{array}$ & $\begin{array}{c}\mathrm{Ni}+2 \\
\text { in liquid } \\
{[\mathrm{Ni}+2]} \\
(\mu \mathrm{g} / \mathrm{mL})\end{array}$ & $\begin{array}{c}\mathrm{K}+1 \\
\text { in liquid } \\
{[\mathrm{K}+1]} \\
(\mu \mathrm{g} / \mathrm{mL})\end{array}$ & $\begin{array}{c}\text { TOC } \\
\text { in liquid } \\
\text { [TOC] } \\
(\mu \mathrm{g} / \mathrm{mL})\end{array}$ \\
\hline & & & & & 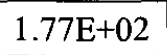 & & $3.93 E+03$ & 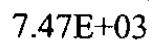 \\
\hline 241 & & -05 & -04 & $\mathrm{E}+01$ & $5 \mathrm{E}+02$ & 2 & 03 & 4 \\
\hline $241-$ & & +05 & 04 & $\mathrm{E}+01$ & $7.08 \mathrm{E}+02$ & & $\mathrm{E}+04$ & +03 \\
\hline 241-AN-104 & & $\mathrm{E}+05$ & $.85 \mathrm{E}+04$ & $\mathrm{E}+01$ & $5.04 \mathrm{E}+02$ & & $a+04$ & 03 \\
\hline $241-$ & & 05 & -04 & +01 & $3.17 \mathrm{E}+02$ & 01 & $9.29 \mathrm{E}+03$ & $3.95 \mathrm{E}+03$ \\
\hline 241 & & 05 & 04 & $8+00$ & +02 & 1.5 & +04 & $E+04$ \\
\hline 241 & 10 & 05 & 03 & 03 & 02 & 02 & -03 & +04 \\
\hline 241 & & -05 & 04 & +00 & $86 \mathrm{E}+02$ & 01 & +04 & 03 \\
\hline $241-$ & & 2.99 & 04 & +00 & $9.52 \mathrm{E}+02$ & 1 & 03 & +03 \\
\hline $241-A$ & & $3.05 E+05$ & $3.14 \mathrm{E}+04$ & $5.15 \mathrm{E}+01$ & $6.37 \mathrm{E}+02$ & $2.09 \mathrm{E}+02$ & $2.28 \mathrm{E}+04$ & $1.24 \mathrm{E}+04$ \\
\hline 241-AP-104 & & $2.75 \mathrm{E}+05$ & $3.59 \mathrm{E}+04$ & $2.23 \mathrm{E}+02$ & $2.94 \mathrm{E}+03$ & $1.68 \mathrm{E}+02$ & $4.52 \mathrm{E}+03$ & $8.90 \mathrm{E}+03$ \\
\hline $241-\mathrm{A}$ & & $97 \mathrm{E}+05$ & $4.27 \mathrm{E}+04$ & $6.69 \mathrm{E}+01$ & $1.14 \mathrm{E}+03$ & $5.65 \mathrm{E}+01$ & $E+04$ & $3.32 \mathrm{E}+03$ \\
\hline 241-AP-106 & 86 & $2.96 \mathrm{E}+05$ & $3.86 \mathrm{E}+04$ & $3.23 E+02$ & $4.47 \mathrm{E}+03$ & 2.16 & $8.91 \mathrm{E}+03$ & $9.90 \mathrm{E}+03$ \\
\hline 241-A & & $2.64 \mathrm{E}+05$ & $2.99 \mathrm{E}+04$ & $2.18 \mathrm{E}+01$ & $1.42 \mathrm{E}+03$ & $5.10 \mathrm{E}+00$ & $E+03$ & $5.04 \mathrm{E}+03$ \\
\hline $241-A$ & 1 & $2.78 \mathrm{E}+05$ & $3.32 \mathrm{E}+04$ & $1.41 \mathrm{E}+01$ & $1.15 \mathrm{E}+03$ & $5.61 \mathrm{E}+00$ & +03 & $5.84 \mathrm{E}+03$ \\
\hline $241-A$ & & $2.97 \mathrm{E}+05$ & $3.77 \mathrm{E}+04$ & $2.30 \mathrm{E}+01$ & $1.43 \mathrm{E}+02$ & $7.79 \mathrm{E}+00$ & +04 & $3.34 \mathrm{E}+03$ \\
\hline 241-AW-102 & 2 & $2.68 \mathrm{E}+05$ & $3.06 \mathrm{E}+04$ & $1.60 \mathrm{E}+01$ & $1.11 \mathrm{E}+03$ & $4.38 E+00$ & $3.05 \mathrm{E}+03$ & $5.20 \mathrm{E}+03$ \\
\hline 241-AW-103 & 50 & $4.06 \mathrm{E}+05$ & $4.04 \mathrm{E}+04$ & $1.39 \mathrm{E}+01$ & $6.32 \mathrm{E}+01$ & $1.27 \mathrm{E}+01$ & $3.57 \mathrm{E}+04$ & $5.15 \mathrm{E}+03$ \\
\hline 241-AW-104 & 1 & $2.91 \mathrm{E}+05$ & $4.36 \mathrm{E}+04$ & $3.19 \mathrm{E}+00$ & $3.77 \mathrm{E}+00$ & $1.27 \mathrm{E}+00$ & $2.86 \mathrm{E}+03$ & $7.40 \mathrm{E}+03$ \\
\hline 241-AW-105 & .00 & $2.26 \mathrm{E}+05$ & $1.43 \mathrm{E}+03$ & $4.61 \mathrm{E}+01$ & $2.12 \mathrm{E}+01$ & $9.91 \mathrm{E}+00$ & $1.99 \mathrm{E}+04$ & $4.08 \mathrm{E}+03$ \\
\hline 241-AW-106 & 2.00 & $2.89 \mathrm{E}+05$ & $4.20 \mathrm{E}+04$ & $4.36 \mathrm{E}+01$ & $2.94 \mathrm{E}+03$ & $1.68 \mathrm{E}+01$ & $1.13 \mathrm{E}+04$ & $3.53 \mathrm{E}+03$ \\
\hline 241-AY-101 & 3.16 & $3.66 \mathrm{E}+05$ & $1.50 \mathrm{E}+04$ & $3.79 \mathrm{E}+01$ & $3.32 \mathrm{E}+02$ & $1.86 \mathrm{E}+02$ & $2.41 \mathrm{E}+03$ & $4.27 \mathrm{E}+03$ \\
\hline 241-AY-102 & 3.51 & $2.00 \mathrm{E}+05$ & $4.04 \mathrm{E}+03$ & $3.55 \mathrm{E}+01$ & $1.02 \mathrm{E}+02$ & $1.41 \mathrm{E}+01$ & $1.36 \mathrm{E}+03$ & $2.87 \mathrm{E}+03$ \\
\hline 241-AZ-101 & 2.50 & $2.80 \mathrm{E}+05$ & $1.53 \mathrm{E}+04$ & $5.60 \mathrm{E}+01$ & $1.81 \mathrm{E}+03$ & $2.00 \mathrm{E}+01$ & $1.19 \mathrm{E}+04$ & $1.28 \mathrm{E}+03$ \\
\hline 241-AZ-102 & & $3.36 \mathrm{E}+05$ & $1.86 \mathrm{E}+03$ & $5.45 \mathrm{E}+00$ & $4.02 \mathrm{E}+03$ & $9.55 \mathrm{E}+00$ & $1.75 \mathrm{E}+04$ & $1.09 \mathrm{E}+04$ \\
\hline 241-SY-101 & 0 & $2.75 \mathrm{E}+05$ & $1.89 \mathrm{E}+04$ & $7.94 \mathrm{E}+02$ & $1.04 \mathrm{E}+04$ & $4.03 E+02$ & $8.28 \mathrm{E}+03$ & $4.61 \mathrm{E}+03$ \\
\hline $241-$ & & $2.72 \mathrm{E}+05$ & $1.87 \mathrm{E}+04$ & $3.13 \mathrm{E}+01$ & $5.36 \mathrm{E}+02$ & $1.12 \mathrm{E}+02$ & $3.40 \mathrm{E}+03$ & $2.76 E+03$ \\
\hline 241-SY-103 & 1.28 & $2.74 \mathrm{E}+05$ & $4.80 \mathrm{E}+04$ & $2.68 \mathrm{E}+01$ & $4.21 E+01$ & $6.26 \mathrm{E}+01$ & $4.99 \mathrm{E}+03$ & $7.94 \mathrm{E}+03$ \\
\hline
\end{tabular}


Table A-3b. Concentrated Input Data for Hydrogen Generation and Ammonia Equilibrium Model Calculations at Target SpG of 1.6.

\begin{tabular}{|c|c|c|c|c|c|c|c|c|}
\hline $\begin{array}{l}\text { Supernatant } \\
\text { waste }\end{array}$ & $\begin{array}{c}\mathrm{OH}^{-1} \\
\text { in liquid } \\
{[\mathrm{OH}]} \\
(\mu \mathrm{g} / \mathrm{mL})\end{array}$ & $\begin{array}{c}\mathrm{NO}_{2}^{-1} \\
\text { in liquid } \\
{\left[\mathrm{NO}_{2}^{-1}\right]} \\
(\mu \mathrm{g} / \mathrm{mL}) \\
\end{array}$ & $\begin{array}{c}\text { NO3 } \\
\text { in liquid } \\
\text { [NO3] } \\
(\mu \mathrm{g} / \mathbf{m L})\end{array}$ & $\begin{array}{c}\mathrm{CO}_{3}^{-2} \\
\text { in liquid } \\
{[\mathrm{CO3}-2]} \\
(\mu \mathrm{g} / \mathrm{mL}) \\
\end{array}$ & $\begin{array}{c}\mathrm{PO}_{4}^{-3} \\
\text { in liquid } \\
{[\mathrm{PO4}-3]} \\
(\mu \mathrm{g} / \mathrm{mL}) \\
\end{array}$ & $\begin{array}{c}\mathrm{SO}_{4}^{-2} \\
\text { in liquid } \\
\text { [SO4-2] } \\
(\mu \mathrm{g} / \mathrm{mL}) \\
\end{array}$ & $\begin{array}{c}\mathbf{F}^{-1} \\
\text { in liquid } \\
{\left[F^{-1}\right]} \\
(\mu \mathrm{g} / \mathrm{mL}) \\
\end{array}$ & $\begin{array}{c}\mathrm{Cl}^{-1} \\
\text { in liquid } \\
{\left[\mathrm{Cl}^{-1}\right]} \\
(\mu \mathrm{g} / \mathrm{mL})\end{array}$ \\
\hline 241 & $13 \mathrm{E}+04$ & $1.70 \mathrm{E}+05$ & $2.37 \mathrm{E}+05$ & $1.41 \mathrm{E}+04$ & $2.33 \mathrm{E}+03$ & $1.99 \mathrm{E}+03$ & $4.22 \mathrm{E}+02$ & $3.42 \mathrm{E}+03$ \\
\hline $\mathrm{N}-102$ & $30 \mathrm{E}+04$ & $27 \mathrm{E}+05$ & $3.06 \mathrm{E}+05$ & $1.02 \mathrm{E}+05$ & $8.07 \mathrm{E}+03$ & $2.24 \mathrm{E}+04$ & $2.79 \mathrm{E}+03$ & $6.02 \mathrm{E}+03$ \\
\hline 241-AN-103 & $40 \mathrm{E}+04$ & $1.63 E+05$ & $1.61 \mathrm{E}+05$ & $7.25 \mathrm{E}+03$ & $2.06 \mathrm{E}+03$ & $1.81 \mathrm{E}+03$ & $8.25 \mathrm{E}+02$ & $1.22 \mathrm{E}+04$ \\
\hline N-104 & $9.79 \mathrm{E}+04$ & $1.79 \mathrm{E}+05$ & $2.84 \mathrm{E}+05$ & $1.60 \mathrm{E}+04$ & $4.06 \mathrm{E}+03$ & $5.31 \mathrm{E}+03$ & $1.23 \mathrm{E}+02$ & $1.21 \mathrm{E}+04$ \\
\hline 241-AN-105 & $3 \mathrm{E}+04$ & $9 \mathrm{E}+05$ & $23 E+05$ & $1.69 \mathrm{E}+04$ & $1.75 \mathrm{E}+03$ & $4.07 \mathrm{E}+03$ & $4.37 \mathrm{E}+02$ & $1.41 \mathrm{E}+04$ \\
\hline 241 & +04 & $E+05$ & $E+05$ & $1.19 \mathrm{E}+05$ & +04 & $E+04$ & $2.79 E+04$ & $5.24 \mathrm{E}+03$ \\
\hline 241-AN-107 & $1 \mathrm{E}+04$ & $\mathrm{E}+04$ & $2.92 \mathrm{E}+05$ & $1.05 \mathrm{E}+05$ & $4.10 \mathrm{E}+03$ & $1.25 \mathrm{E}+04$ & $5.83 \mathrm{E}+03$ & $2.82 \mathrm{E}+03$ \\
\hline $241-$ & $6 \mathrm{E}+04$ & $E+04$ & $2.35 E+05$ & $6.46 \mathrm{E}+04$ & $2.04 \mathrm{E}+03$ & $8.06 \mathrm{E}+03$ & $5.80 \mathrm{E}+03$ & $3.96 \mathrm{E}+03$ \\
\hline 241 & +04 & +05 & $7 \mathrm{E}+05$ & $4.10 \mathrm{E}+04$ & $1.78 \mathrm{E}+04$ & $5 \mathrm{E}+03$ & $2.58 \mathrm{E}+02$ & $4.20 \mathrm{E}+03$ \\
\hline 241 & 04 & 55 & 05 & +05 & $5.93 \mathrm{E}+03$ & $\mathrm{E}+03$ & $3.58 \mathrm{E}+03$ & $4.83 \mathrm{E}+03$ \\
\hline 241 & 04 & 05 & 05 & +04 & +03 & +03 & $9 \mathrm{E}+02$ & $\mathrm{E}+04$ \\
\hline 241 & -04 & 05 & 05 & +05 & +03 & $8+04$ & $1.05 \mathrm{E}+04$ & $\mathrm{E}+04$ \\
\hline 241 & 04 & 05 & 2 & +04 & +03 & $E+03$ & $1.92 \mathrm{E}+03$ & $\mathrm{E}+04$ \\
\hline 241 & 04 & -05 & 5 & -03 & +04 & +03 & $1.56 \mathrm{E}+03$ & +03 \\
\hline 241-AP-108 & $2 \mathrm{E}+04$ & 05 & 2 & +04 & +03 & $E+03$ & $1.35 \mathrm{E}+03$ & $E+03$ \\
\hline $241-f$ & 1 & 1 & 2 & 04 & 03 & +03 & +03 & $2 E+03$ \\
\hline 241 & $\mathrm{E}+04$ & . & 2 & 3 & 03 & $3.97 \mathrm{E}+03$ & $1.25 \mathrm{E}+03$ & $3.88 \mathrm{E}+03$ \\
\hline 24 & $E+04$ & $E+05$ & 3 & 04 & $\mathrm{E}+02$ & $1.68 \mathrm{E}+03$ & $4.20 \mathrm{E}+04$ & $3.45 \mathrm{E}+02$ \\
\hline 241-AW & $4.34 \mathrm{E}+04$ & & & $1.24 \mathrm{E}+04$ & $5.02 \mathrm{E}+02$ & $1.12 \mathrm{E}+03$ & $2.26 \mathrm{E}+02$ & $4.10 \mathrm{E}+02$ \\
\hline 241-AY & $4.38 \mathrm{E}+04$ & $2.55 \mathrm{E}+04$ & $2.46 \mathrm{E}+05$ & $1.62 \mathrm{E}+04$ & $1.85 \mathrm{E}+03$ & $3.01 E+03$ & $4.81 \mathrm{E}+03$ & $2.45 \mathrm{E}+03$ \\
\hline 241-AW-106 & $5.44 \mathrm{E}+04$ & $1.10 \mathrm{E}+05$ & $2.28 \mathrm{E}+05$ & $5.68 \mathrm{E}+04$ & $2.94 \mathrm{E}+03$ & $1.03 \mathrm{E}+04$ & $2.46 \mathrm{E}+03$ & $1.03 E+04$ \\
\hline 241-AY-101 & $1.09 \mathrm{E}+05$ & $1.06 \mathrm{E}+05$ & $17 \mathrm{E}+04$ & $1.09 \mathrm{E}+05$ & $3.63 E+03$ & $1.85 \mathrm{E}+04$ & $5.49 \mathrm{E}+02$ & $2.01 \mathrm{E}+03$ \\
\hline 241-AY-102 & $2.72 \mathrm{E}+04$ & $1.05 \mathrm{E}+05$ & $1.37 \mathrm{E}+03$ & $1.71 \mathrm{E}+05$ & $1.06 \mathrm{E}+04$ & $8.15 \mathrm{E}+03$ & $6.04 \mathrm{E}+02$ & $5.62 \mathrm{E}+02$ \\
\hline 241-AZ-101 & $2.87 \mathrm{E}+04$ & $1.55 \mathrm{E}+05$ & $1.33 \mathrm{E}+05$ & $8.55 \mathrm{E}+04$ & $3.34 E+03$ & $3.76 \mathrm{E}+04$ & $4.38 \mathrm{E}+03$ & $3.77 \mathrm{E}+02$ \\
\hline 241-AZ-102 & $1.34 \mathrm{E}+04$ & $2.22 \mathrm{E}+05$ & $4.49 \mathrm{E}+04$ & $1.91 \mathrm{E}+05$ & $2.71 \mathrm{E}+03$ & $1.01 \mathrm{E}+05$ & $6.22 \mathrm{E}+03$ & $4.18 \mathrm{E}+02$ \\
\hline 241-SY-101 & $7.48 \mathrm{E}+04$ & $8.29 \mathrm{E}+04$ & $2.06 \mathrm{E}+05$ & $6.87 \mathrm{E}+04$ & $9.88 \mathrm{E}+03$ & $8.38 \mathrm{E}+03$ & $1.10 \mathrm{E}+03$ & $2.22 \mathrm{E}+04$ \\
\hline 241-SY-102 & $2.14 \mathrm{E}+04$ & $5.44 \mathrm{E}+04$ & $3.66 \mathrm{E}+05$ & $2.91 \mathrm{E}+04$ & $7.73 \mathrm{E}+03$ & $6.47 \mathrm{E}+03$ & $3.36 \mathrm{E}+02$ & $1.03 E+04$ \\
\hline 241-SY-103 & $3.81 \mathrm{E}+04$ & $1.95 \mathrm{E}+05$ & $2.14 \mathrm{E}+05$ & $4.39 \mathrm{E}+04$ & $3.98 \mathrm{E}+03$ & $5.21 \mathrm{E}+03$ & $4.48 \mathrm{E}+02$ & $1.48 \mathrm{E}+04$ \\
\hline
\end{tabular}


Table A-3c. Concentrated Input Data for Hydrogen Generation and Ammonia Equilibrium Model Calculations at Target SpG of 1.6.

\begin{tabular}{|c|c|c|c|c|c|c|c|c|}
\hline $\begin{array}{l}\text { Supernatant } \\
\text { waste }\end{array}$ & $\begin{array}{c}{ }^{90} \mathrm{Sr} \\
\text { in waste } \\
{[\mathrm{Sr}]} \\
(\mu \mathrm{Ci} / \mathrm{g}) \\
\end{array}$ & $\begin{array}{c}{ }^{241} \mathrm{Am} \\
\text { in waste } \\
{[\mathrm{Am} 241]} \\
(\mu \mathrm{Ci} / \mathrm{g}) \\
\end{array}$ & $\begin{array}{c}{ }^{240} \mathrm{Pu} \\
\text { in waste } \\
{[\mathrm{Pu} 240]} \\
(\mu \mathrm{Ci} / \mathrm{g})\end{array}$ & $\begin{array}{c}{ }^{239} \mathrm{Pu} \\
\text { in waste } \\
{[\mathrm{Pu} 240]} \\
(\mu \mathrm{Ci} / \mathrm{g})\end{array}$ & $\begin{array}{c}{ }^{238} \mathrm{Pu} \\
\text { in waste } \\
{[\mathrm{Pu} 238]} \\
(\mu \mathrm{Ci} / \mathrm{g})\end{array}$ & $\begin{array}{c}{ }^{137} \mathrm{Cs} \\
\text { in waste } \\
{[\mathrm{Cs}]} \\
(\mu \mathrm{Ci} / \mathrm{g}) \\
\end{array}$ & $\begin{array}{c}\text { Liquid } \\
\mathrm{NH}_{3} \\
(\mu \mathrm{g} / \mathrm{mL})\end{array}$ & $\begin{array}{c}\text { Liquid } \\
\text { water } \\
{[\mathrm{H2O}]} \\
(\mathrm{wt} \%) \\
\end{array}$ \\
\hline 241-AN-101 & $1.64 \mathrm{E}+00$ & $8.48 \mathrm{E}-04$ & $1.33 \mathrm{E}-05$ & $8.01 \mathrm{E}-05$ & $1.98 \mathrm{E}-06$ & $2.56 \mathrm{E}+02$ & $5.05 \mathrm{E}+01$ & $37 \%$ \\
\hline 241-AN-102 & $7.23 \mathrm{E}+01$ & $1.48 \mathrm{E}-01$ & $1.13 \mathrm{E}-03$ & $4.35 \mathrm{E}-03$ & $3.16 \mathrm{E}-04$ & $3.59 \mathrm{E}+02$ & $6.30 \mathrm{E}+01$ & $26 \%$ \\
\hline 241-AN-103 & $1.38 \mathrm{E}-02$ & $4.75 \mathrm{E}-03$ & $5.17 \mathrm{E}-05$ & $1.99 \mathrm{E}-04$ & $1.45 \mathrm{E}-05$ & $4.92 \mathrm{E}+02$ & $1.04 \mathrm{E}+02$ & $38 \%$ \\
\hline N-104 & $7.67 \mathrm{E}-02$ & $3.29 \mathrm{E}-04$ & $1.76 \mathrm{E}-05$ & $6.77 \mathrm{E}-05$ & $4.90 \mathrm{E}-06$ & $4.61 \mathrm{E}+02$ & $7.38 \mathrm{E}+01$ & $36 \%$ \\
\hline 241 & $3.10 \mathrm{E}-02$ & $1.28 \mathrm{E}-02$ & $1.40 \mathrm{E}-04$ & 5.37E-04 & $3.90 \mathrm{E}-05$ & $2.61 \mathrm{E}+02$ & $6.30 \mathrm{E}+01$ & $36 \%$ \\
\hline 241-AN-106 & $2.16 \mathrm{E}+00$ & $1.58 \mathrm{E}-03$ & $1.79 \mathrm{E}-03$ & $1.15 \mathrm{E}-02$ & $1.83 \mathrm{E}-04$ & $1.77 \mathrm{E}+02$ & $6.30 \mathrm{E}+01$ & $32 \%$ \\
\hline 241-AN-107 & $6.69 \mathrm{E}+01$ & $6.37 \mathrm{E}-01$ & $1.02 \mathrm{E}-02$ & $3.94 \mathrm{E}-02$ & $2.86 \mathrm{E}-03$ & $2.61 \mathrm{E}+02$ & $6.30 \mathrm{E}+01$ & $40 \%$ \\
\hline 241-AP-101 & $1.22 \mathrm{E}-01$ & $2.41 \mathrm{E}-04$ & $3.41 \mathrm{E}-05$ & $1.31 \mathrm{E}-04$ & $9.51 \mathrm{E}-06$ & $1.74 \mathrm{E}+02$ & $1.32 \mathrm{E}+02$ & $41 \%$ \\
\hline 241-AP-102 & $3.70 \mathrm{E}-01$ & $1.66 \mathrm{E}-03$ & $5.01 \mathrm{E}-05$ & 2.97E-04 & $7.69 \mathrm{E}-06$ & $2.29 \mathrm{E}+02$ & $1.32 \mathrm{E}+02$ & $45 \%$ \\
\hline 241-AP-103 & $2.58 \mathrm{E}+00$ & $1.18 \mathrm{E}-02$ & $1.67 \mathrm{E}-04$ & $9.99 \mathrm{E}-04$ & $3.09 \mathrm{E}-05$ & $2.45 \mathrm{E}+02$ & $7.50 \mathrm{E}+01$ & $38 \%$ \\
\hline $241-$ & $2.24 \mathrm{E}+00$ & 3.10 & 3.41 & -03 & 5.31 & $2.48 \mathrm{E}+02$ & $3.99 \mathrm{E}+01$ & 4 \\
\hline 241 & 3.77 & 9.61 & 6.4 & 04 & 2.2 & $E+02$ & $2 \mathrm{E}+01$ & $50 \%$ \\
\hline 24 & $2.13 \mathrm{E}+00$ & 1. & 2.2 & 04 & 3. & +02 & $2.03 \mathrm{E}+01$ & $40 \%$ \\
\hline 241-AP-107 & $1.35 \mathrm{E}+00$ & 7.03 & 1.6 & 34 & $2.33 \mathrm{E}$ & $1.79 \mathrm{E}+02$ & $3.42 \mathrm{E}+02$ & 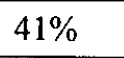 \\
\hline 241-AP-108 & $6.25 \mathrm{E}-01$ & 2.92 & 5.81 & 04 & $2.14 \mathrm{E}-05$ & $1.75 \mathrm{E}+02$ & $2.89 \mathrm{E}+02$ & $72 \pi$ \\
\hline 241-AW-101 & $3.00 \mathrm{E}-01$ & $2.08 \mathrm{E}-04$ & $8.53 \mathrm{E}-05$ & 04 & $2.38 \mathrm{E}-05$ & $3.02 \mathrm{E}+02$ & $3.00 \mathrm{E}+00$ & 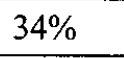 \\
\hline 241-AW-102 & $1.27 \mathrm{E}+00$ & 6. & 55 & 04 & $4 \mathrm{E}-05$ & $1.80 \mathrm{E}+02$ & $2.23 \mathrm{E}+01$ & $41 \%$ \\
\hline 241-AW-103 & $3.43 \mathrm{E}-01$ & 7.97E-05 & $3.94 \mathrm{E}-05$ & $1.86 \mathrm{E}-04$ & $1.68 \mathrm{E}-05$ & $1.75 \mathrm{E}+02$ & $1.54 \mathrm{E}+02$ & $34 \%$ \\
\hline 241-AW-104 & $1.74 \mathrm{E}+00$ & $1.68 \mathrm{E}-03$ & $2.72 \mathrm{E}-05$ & $1.52 \mathrm{E}-04$ & $4.86 \mathrm{E}-06$ & $2.56 \mathrm{E}+02$ & $5.07 \mathrm{E}+01$ & $52 \%$ \\
\hline 241-AW-105 & $1.38 \mathrm{E}-01$ & $3.99 \mathrm{E}-04$ & 4.04E-04 & $1.43 \mathrm{E}-03$ & $1.42 \mathrm{E}-04$ & $6.24 \mathrm{E}+01$ & $3.03 \mathrm{E}+02$ & $33 \%$ \\
\hline 241-AW-106 & $5.79 \mathrm{E}-01$ & $9.43 \mathrm{E}-04$ & $4.67 \mathrm{E}-05$ & $2.96 \mathrm{E}-04$ & $6.22 \mathrm{E}-06$ & $1.93 \mathrm{E}+02$ & $1.07 \mathrm{E}+02$ & $55 \%$ \\
\hline 241-AY-101 & $1.83 \mathrm{E}+00$ & $5.20 \mathrm{E}-03$ & $7.89 \mathrm{E}-03$ & $3.38 \mathrm{E}-02$ & $1.41 \mathrm{E}-03$ & $9.17 \mathrm{E}+01$ & $3.39 \mathrm{E}+01$ & $52 \%$ \\
\hline 241-AY-102 & $2.48 \mathrm{E}+00$ & $4.61 \mathrm{E}-04$ & 7.49E-04 & $3.45 \mathrm{E}-03$ & $5.54 \mathrm{E}-04$ & $4.39 \mathrm{E}+01$ & $2.21 \mathrm{E}+01$ & $56 \%$ \\
\hline 241-AZ-101 & $1.37 \mathrm{E}+00$ & $2.27 \mathrm{E}-04$ & $6.32 \mathrm{E}-04$ & $2.21 \mathrm{E}-03$ & $2.29 \mathrm{E}-04$ & $2.46 \mathrm{E}+03$ & $3.75 \mathrm{E}+01$ & $48 \%$ \\
\hline 241-AZ-102 & $6.69 \mathrm{E}+00$ & $2.13 \mathrm{E}-03$ & $6.80 \mathrm{E}-03$ & $2.49 \mathrm{E}-02$ & $2.41 \mathrm{E}-03$ & $3.22 \mathrm{E}+03$ & $1.31 \mathrm{E}+02$ & $36 \%$ \\
\hline 241-SY-101 & $2.75 \mathrm{E}+00$ & $7.11 \mathrm{E}-04$ & $2.85 \mathrm{E}-05$ & $1.80 \mathrm{E}-04$ & $3.83 \mathrm{E}-06$ & $1.47 \mathrm{E}+02$ & $3.13 \mathrm{E}+02$ & $42 \%$ \\
\hline 241-SY-102 & $1.64 \mathrm{E}-01$ & 5.22E-04 & $2.40 \mathrm{E}-05$ & $1.46 \mathrm{E}-04$ & $3.51 \mathrm{E}-06$ & $1.05 \mathrm{E}+02$ & $3.45 \mathrm{E}+02$ & $38 \%$ \\
\hline 241-SY-103 & $2.40 \mathrm{E}+00$ & $8.12 \mathrm{E}-03$ & 9.34E-06 & $4.35 \mathrm{E}-05$ & $1.52 \mathrm{E}-06$ & $3.42 \mathrm{E}+02$ & $3.87 \mathrm{E}+02$ & $33 \%$ \\
\hline
\end{tabular}


RPP-CALC-29700 REV 1

APPENDIX B

FLAMMABILITY ANALYSIS RESULTS ON EVAPORATOR VESSEL C-A-1

B-i 
RPP-CALC-29700 REV 1

This page intentionally left blank.

B-ii 


\section{APPENDIX B}

\section{FLAMMABILITY ANALYSIS RESULTS ON EVAPORATOR VESSEL C-A-1}

Table B-1. Feed Waste Condition and Time to Lower Flammability Limit for Evaporator Vessel at $62 \%$ Filled.

\begin{tabular}{|c|c|c|c|c|c|c|c|c|c|}
\hline Tanks & $\begin{array}{c}\text { Na } \\
\text { in liquid } \\
\text { [Na] } \\
(\mu \mathrm{g} / \mathrm{mL})\end{array}$ & $\begin{array}{c}\mathrm{NO}_{3} \\
\text { in liquid } \\
{[\mathrm{NO3}]} \\
(\mu \mathrm{g} / \mathrm{mL})\end{array}$ & $\begin{array}{c}\mathrm{NO}_{2} \\
\text { in liquid } \\
{[\mathrm{NO2}]} \\
(\mu \mathrm{g} / \mathrm{mL})\end{array}$ & $\begin{array}{c}\text { Liquid } \\
\text { density } \\
\text { DL } \\
(\mathrm{g} / \mathrm{ml})\end{array}$ & $\begin{array}{c}\text { Liquid } \\
\text { NH3 } \\
(\mu \mathrm{g} / \mathrm{mL})\end{array}$ & $\begin{array}{c}\text { Liquid } \\
\text { water } \\
{[\mathrm{H2O}]} \\
(\mathrm{wt} \%)\end{array}$ & $\begin{array}{c}\text { Waste } \\
\text { temp. } \\
\text { Tw } \\
\left({ }^{\circ} \mathrm{C}\right)\end{array}$ & $\begin{array}{l}\text { Time to } \\
\text { reach } \\
25 \% \text { LFL } \\
\text { at zero } \\
\text { vent } \\
\text { (days) }\end{array}$ & $\begin{array}{c}\text { Time to } \\
\text { reach } \\
100 \% \text { LFL } \\
\text { at zero vent } \\
\text { (days) }\end{array}$ \\
\hline 241-AN-101 & $2.14 \mathrm{E}+05$ & $1.62 \mathrm{E}+05$ & $1.16 \mathrm{E}+05$ & 1.41 & 168 & $52 \%$ & 27 & 243 & 977 \\
\hline 241-AN-102 & $2.07 \mathrm{E}+05$ & $2.09 \mathrm{E}+05$ & $8.71 E+04$ & 1.41 & 210 & $43 \%$ & 32 & 54 & 221 \\
\hline 241-AN-103 & $2.70 \mathrm{E}+05$ & $1.29 \mathrm{E}+05$ & $1.30 \mathrm{E}+05$ & 1.48 & 345 & $47 \%$ & 38 & 125 & 534 \\
\hline 241-AN-104 & $2.58 \mathrm{E}+05$ & $1.89 \mathrm{E}+05$ & $1.19 \mathrm{E}+05$ & 1.40 & 246 & $51 \%$ & 35 & 153 & 636 \\
\hline 241-AN-105 & $2.47 \mathrm{E}+05$ & $1.56 \mathrm{E}+05$ & $1.19 \mathrm{E}+05$ & 1.42 & 210 & $50 \%$ & 32 & 220 & 908 \\
\hline 241-AN-106 & $4.49 \mathrm{E}+04$ & $2.53 \mathrm{E}+04$ & $2.01 \mathrm{E}+04$ & 1.11 & 210 & $82 \%$ & 24 & 402 & 1631 \\
\hline 241-AN-107 & $2.08 \mathrm{E}+05$ & $2.09 \mathrm{E}+05$ & $6.67 \mathrm{E}+04$ & 1.43 & 210 & $52 \%$ & 33 & 69 & 279 \\
\hline 241-AP-101 & $1.29 \mathrm{E}+05$ & $1.18 \mathrm{E}+05$ & $4.08 \mathrm{E}+04$ & 1.30 & 439 & $64 \%$ & 21 & 450 & 1833 \\
\hline 241-AP-102 & $1.94 \mathrm{E}+05$ & $1.67 \mathrm{E}+05$ & $9.82 \mathrm{E}+04$ & 1.39 & 439 & $59 \%$ & 21 & 359 & 1475 \\
\hline 241-AP-103 & $1.78 \mathrm{E}+05$ & $1.49 \mathrm{E}+05$ & $8.04 \mathrm{E}+04$ & 1.35 & 250 & $57 \%$ & 21 & 280 & 1136 \\
\hline 241-AP-104 & $1.28 \mathrm{E}+05$ & $1.01 \mathrm{E}+05$ & $6.39 E+04$ & 1.28 & 133 & $66 \%$ & 23 & 301 & 1216 \\
\hline 241-AP-105 & $1.34 \mathrm{E}+05$ & $1.06 \mathrm{E}+05$ & $4.73 E+04$ & 1.27 & 324 & $71 \%$ & 19 & 464 & 1892 \\
\hline 241-AP-106 & $1.03 \mathrm{E}+05$ & $7.07 \mathrm{E}+04$ & $4.14 \mathrm{E}+04$ & 1.21 & 68 & $72 \%$ & 24 & 290 & 1168 \\
\hline 241-AP-107 & $1.22 \mathrm{E}+05$ & $1.12 \mathrm{E}+05$ & $5.14 \mathrm{E}+04$ & 1.28 & 1140 & $66 \%$ & 20 & 415 & 1716 \\
\hline 241-AP-108 & $1.99 \mathrm{E}+05$ & $1.76 \mathrm{E}+05$ & $8.02 \mathrm{E}+04$ & 1.43 & 963 & $53 \%$ & 32 & 199 & 843 \\
\hline 241-AW-101 & $2.33 \mathrm{E}+05$ & $1.71 \mathrm{E}+05$ & $1.05 \mathrm{E}+05$ & 1.47 & 10 & $44 \%$ & 32 & 237 & 952 \\
\hline 241-AW-102 & $1.16 \mathrm{E}+05$ & $1.06 \mathrm{E}+05$ & $4.87 \mathrm{E}+04$ & 1.26 & 74 & $67 \%$ & 22 & 417 & 1681 \\
\hline 241-AW-103 & $1.62 \mathrm{E}+05$ & $1.31 \mathrm{E}+05$ & $4.30 \mathrm{E}+04$ & 1.24 & 512 & $66 \%$ & 21 & 519 & 2000 \\
\hline 241-AW-104 & $1.70 \mathrm{E}+05$ & $1.12 \mathrm{E}+05$ & $7.45 \mathrm{E}+04$ & 1.35 & 169 & $67 \%$ & 28 & 237 & 960 \\
\hline 241-AW-105 & $2.26 \mathrm{E}+04$ & $2.46 \mathrm{E}+04$ & $2.55 \mathrm{E}+03$ & 1.06 & 1010 & $90 \%$ & 19 & 713 & 2000 \\
\hline 241-AW-106 & $1.44 \mathrm{E}+05$ & $1.14 \mathrm{E}+05$ & $5.49 \mathrm{E}+04$ & 1.30 & 355 & $72 \%$ & 26 & 385 & 1574 \\
\hline 241-AY-101 & $1.16 \mathrm{E}+05$ & $4.65 \mathrm{E}+03$ & $3.35 \mathrm{E}+04$ & 1.19 & 113 & $80 \%$ & 42 & 347 & 1409 \\
\hline 241-AY-102 & $5.69 \mathrm{E}+04$ & $3.91 \mathrm{E}+02$ & $2.99 E+04$ & 1.17 & 74 & $83 \%$ & 49 & 377 & 1532 \\
\hline 241-AZ-101 & $1.12 \mathrm{E}+05$ & $5.32 \mathrm{E}+04$ & $6.20 \mathrm{E}+04$ & 1.24 & 125 & $73 \%$ & 72 & 27 & 112 \\
\hline $241-A Z-102$ & $6.15 E+04$ & $8.23 E+03$ & $4.07 \mathrm{E}+04$ & 1.11 & 438 & $83 \%$ & 49 & 34 & 143 \\
\hline 241-SY-101 & $1.37 \mathrm{E}+05$ & $1.03 E+05$ & $4.14 \mathrm{E}+04$ & 1.30 & 1044 & $65 \%$ & 23 & 441 & 1837 \\
\hline 241-SY-102 & $1.22 \mathrm{E}+05$ & $1.65 \mathrm{E}+05$ & $2.45 \mathrm{E}+04$ & 1.27 & 1150 & $65 \%$ & 26 & 540 & 2000 \\
\hline $241-S Y-103$ & $2.15 E+05$ & $1.68 \mathrm{E}+05$ & $1.52 \mathrm{E}+05$ & 1.47 & 1290 & $43 \%$ & 28 & 135 & 606 \\
\hline
\end{tabular}

Notes:

In this calculation, the ammonia concentration is $30 \%$ of the raw waste concentration, while hydrogen uses data in the targeted $\mathrm{SpG}$.

It covers the off-normal condition when it occurred (i.e., lost vacuum and vent) while the process is running steadily or the process is finished.

LFL = lower flammability limit. 
Table B-2. Time to Lower Flammability Limit for Evaporator Vessel C-A-1 with $62 \%$ Filled at SpG 1.5 , Temperature of $120^{\circ} \mathrm{F}, 30 \% \mathrm{NH}_{3}$.

\begin{tabular}{|c|c|c|c|c|c|c|c|c|c|c|}
\hline Tanks & $\begin{array}{c}\text { Ammonia } \\
\text { transport } \\
\text { constant } \\
\text { k1 } \\
(\mathrm{min}-1)\end{array}$ & $\begin{array}{c}\text { Ammonia } \\
\text { transport } \\
\text { constant } \\
\mathbf{k} 2 \\
(\mathrm{M} / \mathrm{min})\end{array}$ & $\begin{array}{c}\mathrm{UH}_{2} \\
\text { hydrogen } \\
\text { unit rate } \\
\text { (mole/m³ } \\
\text { per sec) }\end{array}$ & $\begin{array}{c}\mathrm{UCH}_{4} \\
\text { methane } \\
\text { unit rate } \\
\text { (mole/m } \\
\text { per sec) }\end{array}$ & $\begin{array}{c}\text { Steady- } \\
\text { state } \\
\mathrm{NH}_{3} \\
\mathrm{LFL} \\
(\%)\end{array}$ & $\begin{array}{c}\text { Time to } \\
\text { reach } \\
25 \% \\
\text { LFL at } \\
\text { BB vent } \\
\text { (days) }\end{array}$ & $\begin{array}{l}\text { Time to } \\
\text { reach } \\
100 \% \\
\text { LFL at } \\
\text { BB vent } \\
\text { (days) }\end{array}$ & $\begin{array}{l}\text { Time to } \\
\text { reach } \\
25 \% \\
\text { LFL at } \\
\text { zero } \\
\text { vent } \\
\text { (days) }\end{array}$ & $\begin{array}{c}\text { Time to } \\
\text { reach } \\
100 \% \\
\text { LFL at } \\
\text { zero } \\
\text { vent } \\
\text { (days) }\end{array}$ & $\begin{array}{l}\text { Vent } \\
\text { rate } \\
\text { keep } \\
\text { below } \\
25 \% \\
\text { LFL } \\
\text { (cfh) }\end{array}$ \\
\hline 241-AN-101 & $7.99 \mathrm{E}-03$ & $1.50 \mathrm{E}-07$ & $6.89 \mathrm{E}-08$ & $6.69 \mathrm{E}-09$ & $0.3 \%$ & 39.0 & 233 & 35.8 & 145 & 2.5 \\
\hline 241-AN-102 & $8.64 \mathrm{E}-03$ & $1.78 \mathrm{E}-07$ & $2.93 \mathrm{E}-07$ & $2.91 \mathrm{E}-08$ & $0.4 \%$ & 8.5 & 37 & 8.4 & 34 & 10.6 \\
\hline 241-AN-103 & $5.79 \mathrm{E}-03$ & $3.54 \mathrm{E}-07$ & $4.55 \mathrm{E}-08$ & $4.35 \mathrm{E}-09$ & $1.1 \%$ & 60.1 & 865 & 52.6 & 218 & 1.7 \\
\hline 241-AN-104 & $3.96 \mathrm{E}-03$ & $2.80 \mathrm{E}-07$ & $6.16 \mathrm{E}-08$ & $5.95 \mathrm{E}-09$ & $1.2 \%$ & 42.4 & 284 & 38.6 & 160 & 2.3 \\
\hline $241-\mathrm{AN}-105$ & $4.60 \mathrm{E}-03$ & $2.31 \mathrm{E}-07$ & $4.92 \mathrm{E}-08$ & 4.72E-09 & $0.9 \%$ & 55.4 & 528 & 49.0 & 202 & 1.8 \\
\hline $241-\mathrm{AN}-106$ & $7.54 \mathrm{E}-03$ & $1.93 \mathrm{E}-07$ & $9.29 \mathrm{E}-08$ & $9.09 \mathrm{E}-09$ & $0.4 \%$ & 28.1 & 146 & 26.4 & 107 & 3.4 \\
\hline 241-AN-107 & $1.00 \mathrm{E}-02$ & $1.61 \mathrm{E}-07$ & $1.65 \mathrm{E}-07$ & $1.63 \mathrm{E}-08$ & $0.3 \%$ & 15.4 & 70 & 14.9 & 60 & 6.0 \\
\hline 241-AP-101 & $8.77 \mathrm{E}-03$ & $3.69 \mathrm{E}-07$ & $2.91 \mathrm{E}-08$ & $2.71 \mathrm{E}-09$ & $0.7 \%$ & 104.8 & not occur & 83.6 & 342 & 1.1 \\
\hline 241-AP-102 & $6.81 \mathrm{E}-03$ & 4.22E-07 & $5.27 \mathrm{E}-08$ & $5.07 \mathrm{E}-09$ & $1.1 \%$ & 50.7 & 413 & 45.3 & 188 & 2.0 \\
\hline 241-AP-103 & $6.69 \mathrm{E}-03$ & $2.42 \mathrm{E}-07$ & $1.16 \mathrm{E}-07$ & $1.14 \mathrm{E}-08$ & $0.6 \%$ & 22.0 & 108 & 21.0 & 86 & 4.2 \\
\hline 241-AP-104 & $8.28 \mathrm{E}-03$ & $1.16 \mathrm{E}-07$ & $8.90 \mathrm{E}-08$ & $8.70 \mathrm{E}-09$ & $0.2 \%$ & 29.7 & 156 & 27.8 & 112 & 3.2 \\
\hline 241-AP-105 & 4.25E-03 & $3.63 \mathrm{E}-07$ & $3.67 \mathrm{E}-08$ & $3.47 \mathrm{E}-09$ & $1.5 \%$ & 75.6 & not occur & 64.1 & 269 & 1.4 \\
\hline 241-AP-106 & 7.72E-03 & $6.11 \mathrm{E}-08$ & $1.03 \mathrm{E}-07$ & $1.01 \mathrm{E}-08$ & $0.1 \%$ & 25.6 & 127 & 24.1 & 97 & 3.7 \\
\hline 241-AP-107 & $9.64 \mathrm{E}-03$ & $8.97 \mathrm{E}-07$ & 4.77E-08 & $4.57 \mathrm{E}-09$ & $1.6 \%$ & 55.4 & 301 & 49.0 & 165 & 1.8 \\
\hline 241-AP-108 & $8.88 \mathrm{E}-03$ & $8.03 \mathrm{E}-07$ & $5.62 \mathrm{E}-08$ & $5.42 \mathrm{E}-09$ & $1.6 \%$ & 46.1 & 344 & 41.6 & 175 & 2.1 \\
\hline 241-AW-101 & $6.05 \mathrm{E}-03$ & $1.01 \mathrm{E}-08$ & $3.79 \mathrm{E}-08$ & $3.59 \mathrm{E}-09$ & $0.0 \%$ & 78.3 & not occur & 66.0 & 265 & 1.3 \\
\hline $241-\mathrm{AW}-102$ & $9.69 \mathrm{E}-03$ & $5.82 \mathrm{E}-08$ & $4.94 \mathrm{E}-08$ & $4.74 \mathrm{E}-09$ & $0.1 \%$ & 57.2 & 536 & 50.4 & 203 & 1.8 \\
\hline 241-AW-103 & $4.92 \mathrm{E}-03$ & $5.52 \mathrm{E}-07$ & $5.25 \mathrm{E}-08$ & $5.05 \mathrm{E}-09$ & $2.0 \%$ & 48.8 & 407 & 43.8 & 187 & 2.0 \\
\hline $24 \mathrm{i}-\mathrm{AW}-104$ & $7.82 \mathrm{E}-03$ & $1.52 \mathrm{E}-07$ & $7.98 \mathrm{E}-08$ & $7.78 \mathrm{E}-09$ & $0.3 \%$ & 33.2 & 183 & 30.9 & 125 & 2.9 \\
\hline $241-\mathrm{AW}-105$ & $1.24 \mathrm{E}-02$ & $6.24 \mathrm{E}-07$ & $1.34 \mathrm{E}-08$ & 1.14E-09 & $0.9 \%$ & 379.0 & not occur & 182.0 & 750 & 0.5 \\
\hline 241-AW-106 & $7.28 \mathrm{E}-03$ & $3.31 \mathrm{E}-07$ & $3.88 \mathrm{E}-08$ & 3.68E-09 & $0.8 \%$ & 73.3 & not occur & 62.4 & 256 & 1.4 \\
\hline 241-AY-101 & $4.33 \mathrm{E}-03$ & $1.26 \mathrm{E}-07$ & $2.98 \mathrm{E}-08$ & $2.78 \mathrm{E}-09$ & $0.5 \%$ & 102.7 & not occur & 82.3 & 335 & 1.0 \\
\hline 241-AY-102 & 8.37E-03 & $6.38 \mathrm{E}-08$ & $1.37 \mathrm{E}-08$ & $1.17 \mathrm{E}-09$ & $0.1 \%$ & 383.7 & not occur & 182.9 & 736 & 0.5 \\
\hline 241-AZ-101 & 7.97E-03 & $1.11 \mathrm{E}-07$ & 5.07E-08 & 4.87E-09 & $0.2 \%$ & 55.2 & 483 & 48.9 & 197 & 1.8 \\
\hline $241-\mathrm{AZ}-102$ & $5.00 \mathrm{E}-03$ & $4.70 \mathrm{E}-07$ & $1.64 \mathrm{E}-07$ & $1.62 \mathrm{E}-08$ & $1.66 \%$ & 14.7 & 70 & 14.2 & 60 & 6.3 \\
\hline 241-SY-101 & $8.52 \mathrm{E}-03$ & $8.94 \mathrm{E}-07$ & $3.67 \mathrm{E}-08$ & $3.47 \mathrm{E}-09$ & $1.85 \%$ & 74.4 & not occur & 63.2 & 268 & 1.4 \\
\hline 241-SY-102 & $1.15 \mathrm{E}-02$ & $7.73 \mathrm{E}-07$ & $2.25 \mathrm{E}-08$ & $2.05 \mathrm{E}-09$ & $1.18 \%$ & 144.2 & not occur & 106.2 & 441 & 0.8 \\
\hline 241-SY-103 & $7.36 \mathrm{E}-03$ & $1.20 \mathrm{E}-06$ & $9.25 \mathrm{E}-08$ & $9.05 \mathrm{E}-09$ & $2.86 \%$ & 25.3 & 142 & 23.9 & 105 & 3.7 \\
\hline
\end{tabular}

Notes:

In this calculation, $30 \%$ of the raw waste concentrations is ammonia, while hydrogen uses data in the targeted SpG.

It covers the off-normal condition when it occurred (i.e., lost vacuum and vent) while the process is running steadily or the process is finished.

$\mathrm{BB}=$ barometric breathing.

LFL = lower flammability limit. 
Table B-3. Time to Lower Flammability Limit for Evaporator Vessel C-A-1 with $62 \%$ Filled at SpG 1.5, Temperature of $130^{\circ} \mathrm{F}, 30 \% \mathrm{NH}_{3}$.

\begin{tabular}{|c|c|c|c|c|c|c|c|c|c|c|}
\hline Tanks & $\begin{array}{c}\text { Ammonia } \\
\text { transport } \\
\text { constant } \\
\text { k1 } \\
(\text { min-1) }\end{array}$ & $\begin{array}{c}\text { Ammonia } \\
\text { transport } \\
\text { constant } \\
k 2 \\
(\mathrm{M} / \mathrm{min})\end{array}$ & $\begin{array}{c}\mathrm{UH}_{2} \\
\text { hydrogen } \\
\text { unit rate } \\
\text { (mole/m³ } \\
\text { per sec) }\end{array}$ & $\begin{array}{c}\mathrm{UCH}_{4} \\
\text { methane } \\
\text { unit rate } \\
\text { (mole/m } \\
\text { per sec) }\end{array}$ & $\begin{array}{c}\text { Steady- } \\
\text { state } \\
\mathrm{NH}_{3} \\
\mathrm{LFL} \\
(\%)\end{array}$ & $\begin{array}{l}\text { Time to } \\
\text { reach } \\
25 \% \\
\text { LFL at } \\
\text { BB } \\
\text { vent } \\
\text { (days) } \\
\end{array}$ & $\begin{array}{c}\text { Time to } \\
\text { reach } \\
100 \% \\
\text { LFL at } \\
\text { BB vent } \\
\text { (days) }\end{array}$ & $\begin{array}{c}\text { Time to } \\
\text { reach } \\
25 \% \\
\text { LFL at } \\
\text { zero } \\
\text { vent } \\
\text { (days) } \\
\end{array}$ & $\begin{array}{c}\text { Time to } \\
\text { reach } \\
100 \% \\
\text { LFL at } \\
\text { zero } \\
\text { vent } \\
\text { (days) } \\
\end{array}$ & \begin{tabular}{|} 
Vent \\
rate keep \\
below \\
$25 \%$ \\
LFL \\
(cfh)
\end{tabular} \\
\hline $241-\mathrm{AN}-101$ & 7.62E-03 & $1.54 \mathrm{E}-07$ & $1.16 \mathrm{E}-07$ & $1.14 \mathrm{E}-08$ & $0.4 \%$ & 22 & 106 & 20.9 & 85 & 4.3 \\
\hline $241-\mathrm{AN}-102$ & $8.26 \mathrm{E}-03$ & $1.83 \mathrm{E}-07$ & $4.93 \mathrm{E}-07$ & $4.91 \mathrm{E}-08$ & $0.4 \%$ & 5 & 21 & 4.9 & 20 & 18.2 \\
\hline 241-AN-103 & $5.48 \mathrm{E}-03$ & $3.60 \mathrm{E}-07$ & $7.31 \mathrm{E}-08$ & $7.11 \mathrm{E}-09$ & $1.2 \%$ & 35 & 202 & 32.0 & 133 & 2.8 \\
\hline 241-AN-104 & $3.72 \mathrm{E}-03$ & $2.84 \mathrm{E}-07$ & $1.02 \mathrm{E}-07$ & $9.98 \mathrm{E}-09$ & $1.4 \%$ & 24 & 124 & 22.8 & 95 & 3.9 \\
\hline 241-AN-105 & $4.34 \mathrm{E}-03$ & $2.34 \mathrm{E}-07$ & $8.22 \mathrm{E}-08$ & $8.03 \mathrm{E}-09$ & $1.0 \%$ & 31 & 169 & 28.7 & 118 & 3.1 \\
\hline 241-AN-106 & $7.05 \mathrm{E}-03$ & $1.99 \mathrm{E}-07$ & $1.58 \mathrm{E}-07$ & $1.56 \mathrm{E}-08$ & $0.5 \%$ & 16 & 72 & 15.2 & 62 & 5.9 \\
\hline 241-AN-107 & $9.52 \mathrm{E}-03$ & $1.67 \mathrm{E}-07$ & $2.68 \mathrm{E}-07$ & $2.66 \mathrm{E}-08$ & $0.3 \%$ & 9 & 40 & 9.0 & 36 & 9.9 \\
\hline 241-AP-101 & $8.39 \mathrm{E}-03$ & $3.80 \mathrm{E}-07$ & $4.73 \mathrm{E}-08$ & $4.53 \mathrm{E}-09$ & $0.8 \%$ & 57 & 584 & 50.3 & 206 & 1.8 \\
\hline 241-AP-102 & $6.47 \mathrm{E}-03$ & $4.31 \mathrm{E}-07$ & $8.81 \mathrm{E}-08$ & 8.62E-09 & $1.2 \%$ & 28 & 152 & 26.5 & 110 & 3.4 \\
\hline 241-AP-103 & $6.35 \mathrm{E}-03$ & $2.48 \mathrm{E}-07$ & $1.97 \mathrm{E}-07$ & $1.95 \mathrm{E}-08$ & $0.7 \%$ & 12 & 56 & 12.1 & 49 & 7.4 \\
\hline 241-AP-104 & $7.86 \mathrm{E}-03$ & $1.19 \mathrm{E}-07$ & $1.50 \mathrm{E}-07$ & $1.48 \mathrm{E}-08$ & $0.3 \%$ & 17 & 77 & 16.1 & 65 & 5.5 \\
\hline 241-AP-105 & $4.00 \mathrm{E}-03$ & $3.68 \mathrm{E}-07$ & $6.09 \mathrm{E}-08$ & $5.89 \mathrm{E}-09$ & $1.6 \%$ & 41 & 278 & 37.7 & 159 & 2.4 \\
\hline 241-AP-106 & $7.28 \mathrm{E}-03$ & $6.30 \mathrm{E}-08$ & $1.74 \mathrm{E}-07$ & $1.72 \mathrm{E}-08$ & $0.2 \%$ & 14 & 65 & 14.0 & 56 & 6.3 \\
\hline 241-AP-107 & $9.04 \mathrm{E}-03$ & $9.40 \mathrm{E}-07$ & $7.96 \mathrm{E}-08$ & 7.77E-09 & $1.9 \%$ & 31 & 175 & 28.5 & 121 & 3.1 \\
\hline 241-AP-108 & $8.45 \mathrm{E}-03$ & $8.29 \mathrm{E}-07$ & $9.48 \mathrm{E}-08$ & $9.28 \mathrm{E}-09$ & $1.8 \%$ & 25 & 136 & 24.1 & 102 & 3.7 \\
\hline 241-AW-101 & $5.74 \mathrm{E}-03$ & $1.03 \mathrm{E}-08$ & $6.14 \mathrm{E}-08$ & $5.95 \mathrm{E}-09$ & $0.0 \%$ & 44 & 282 & 39.9 & 160 & 2.2 \\
\hline 241-AW-102 & $9.10 \mathrm{E}-03$ & $6.09 \mathrm{E}-08$ & $8.27 \mathrm{E}-08$ & $8.07 \mathrm{E}-09$ & $0.1 \%$ & 32 & 170 & 29.6 & 119 & 3.0 \\
\hline 241-AW-103 & $4.65 \mathrm{E}-03$ & $5.61 \mathrm{E}-07$ & $8.92 \mathrm{E}-08$ & $8.73 \mathrm{E}-09$ & $2.2 \%$ & 27 & 147 & 25.1 & 108 & 3.5 \\
\hline 241-AW-104 & $7.35 \mathrm{E}-03$ & $1.57 \mathrm{E}-07$ & $1.35 \mathrm{E}-07$ & $1.33 \mathrm{E}-08$ & $0.4 \%$ & 19 & 88 & 17.9 & 73 & 5.0 \\
\hline 241-AW-105 & $1.15 \mathrm{E}-02$ & $6.78 \mathrm{E}-07$ & $2.11 \mathrm{E}-08$ & $1.91 \mathrm{E}-09$ & $1.1 \%$ & 156 & not occur & 112.3 & 465 & 0.8 \\
\hline 241-AW-106 & $6.92 \mathrm{E}-03$ & $3.39 \mathrm{E}-07$ & $6.44 \mathrm{E}-08$ & $6.24 \mathrm{E}-09$ & $0.9 \%$ & 40 & 253 & 36.8 & 151 & 2.4 \\
\hline 241-AY-101 & $4.08 \mathrm{E}-03$ & $1.28 \mathrm{E}-07$ & $5.02 \mathrm{E}-08$ & $4.82 \mathrm{E}-09$ & $0.6 \%$ & 54 & 466 & 47.9 & 195 & 1.7 \\
\hline 241-AY-102 & $7.49 \mathrm{E}-03$ & $6.78 \mathrm{E}-08$ & $2.18 \mathrm{E}-08$ & $1.98 \mathrm{E}-09$ & $0.2 \%$ & 157 & not occur & 112.7 & 454 & 0.8 \\
\hline 241-AZ-101 & $7.44 \mathrm{E}-03$ & $1.15 \mathrm{E}-07$ & $6.00 \mathrm{E}-08$ & $5.80 \mathrm{E}-09$ & $0.3 \%$ & 45 & 295 & 40.5 & 163 & 2.2 \\
\hline 241-AZ-102 & $4.72 \mathrm{E}-03$ & $4.78 \mathrm{E}-07$ & $2.23 \mathrm{E}-07$ & $2.21 \mathrm{E}-08$ & $1.8 \%$ & 10 & 48 & 10.2 & 43 & 8.7 \\
\hline 241-SY-101 & $8.13 \mathrm{E}-03$ & $9.19 \mathrm{E}-07$ & $6.10 \mathrm{E}-08$ & $5.90 \mathrm{E}-09$ & $2.0 \%$ & 40 & 275 & 37.0 & 158 & 2.4 \\
\hline 241-SY-102 & $1.09 \mathrm{E}-02$ & $8.17 \mathrm{E}-07$ & $3.69 \mathrm{E}-08$ & $3.49 \mathrm{E}-09$ & $1.3 \%$ & 74 & not occur & 63.1 & 263 & 1.4 \\
\hline 241-SY-103 & $7.01 \mathrm{E}-03$ & $1.23 \mathrm{E}-06$ & $1.54 \mathrm{E}-07$ & $1.53 \mathrm{E}-08$ & $3.1 \%$ & 14 & 72 & 13.9 & 62 & 6.4 \\
\hline
\end{tabular}

Notes:

In this calculation, $30 \%$ of the raw waste concentrations is ammonia, while hydrogen uses data in the targeted SpG.

It covers the off-normal condition when it occurred (i.e., lost vacuum and vent) while the process is running steadily or the process is finished.

$\mathrm{BB}$ = barometric breathing.

LFL = lower flammability limit. 
Table B-4. Time to Lower Flammability Limit for Evaporator Vessel C-A-1 with $62 \%$ Filled at SpG 1.5, Temperature of $140^{\circ} \mathrm{F}, 30 \% \mathrm{NH}_{3}$.

\begin{tabular}{|c|c|c|c|c|c|c|c|c|c|c|}
\hline Tanks & $\begin{array}{c}\text { Ammonia } \\
\text { transport } \\
\text { constant } \\
\text { k1 } \\
(\text { min-1) }\end{array}$ & $\begin{array}{c}\text { Ammonia } \\
\text { transport } \\
\text { constant } \\
k 2 \\
(\mathrm{M} / \mathrm{min})\end{array}$ & $\begin{array}{c}\mathrm{UH}_{2} \\
\text { hydrogen } \\
\text { unit rate } \\
\text { (mole/m } \\
\text { per sec) }\end{array}$ & $\begin{array}{c}\mathrm{UCH}_{4} \\
\text { methane } \\
\text { unit rate } \\
\text { (mole/m } \\
\text { per sec) }\end{array}$ & $\begin{array}{c}\text { Steady- } \\
\text { state } \\
\mathrm{NH}_{3} \\
\mathrm{LFL} \\
(\%)\end{array}$ & $\begin{array}{c}\text { Time to } \\
\text { reach } \\
25 \% \\
\text { LFL at } \\
\text { BB vent } \\
\text { (days) }\end{array}$ & $\begin{array}{l}\text { Time to } \\
\text { reach } \\
100 \% \\
\text { LFL at } \\
\text { BB vent } \\
\text { (days) }\end{array}$ & $\begin{array}{l}\text { Time to } \\
\text { reach } \\
25 \% \\
\text { LFL at } \\
\text { zero } \\
\text { vent } \\
\text { (days) }\end{array}$ & $\begin{array}{c}\text { Time to } \\
\text { reach } \\
100 \% \\
\text { LFL at } \\
\text { zero } \\
\text { vent } \\
\text { (days) }\end{array}$ & $\begin{array}{c}\text { Vent } \\
\text { rate } \\
\text { keep } \\
\text { below } \\
25 \% \\
\text { LFL } \\
\text { (cfh) }\end{array}$ \\
\hline 241-AN-101 & $7.34 \mathrm{E}-03$ & $1.56 \mathrm{E}-07$ & $1.94 \mathrm{E}-07$ & $1.92 \mathrm{E}-08$ & $0.4 \%$ & 12.6 & 56 & 12.3 & 50 & 7.3 \\
\hline $241-\mathrm{AN}-102$ & $7.97 \mathrm{E}-03$ & $1.87 \mathrm{E}-07$ & $8.23 \mathrm{E}-07$ & $8.21 \mathrm{E}-08$ & $0.4 \%$ & 2.9 & 12 & 2.9 & 12 & 30.9 \\
\hline 241-AN-103 & $5.26 \mathrm{E}-03$ & 3.65E-07 & $1.19 \mathrm{E}-07$ & $1.17 \mathrm{E}-08$ & $1.3 \%$ & 20.1 & 99 & 19.3 & 80 & 4.6 \\
\hline 241-AN-104 & $3.56 \mathrm{E}-03$ & $2.86 \mathrm{E}-07$ & $1.69 \mathrm{E}-07$ & $1.67 \mathrm{E}-08$ & $1.5 \%$ & 13.9 & 65 & 13.4 & 56 & 6.6 \\
\hline 241-AN-105 & 4. $15 \mathrm{E}-03$ & $2.37 \mathrm{E}-07$ & $1.38 \mathrm{E}-07$ & $1.36 \mathrm{E}-08$ & $1.0 \%$ & 17.5 & 83 & 16.8 & 69 & 5.3 \\
\hline 241-AN-106 & $6.70 \mathrm{E}-03$ & $2.03 \mathrm{E}-07$ & $2.67 \mathrm{E}-07$ & $2.65 \mathrm{E}-08$ & $0.6 \%$ & 9.0 & 39 & 8.8 & 36 & 10.1 \\
\hline 241-AN-107 & $9.18 \mathrm{E}-03$ & $1.71 \mathrm{E}-07$ & $4.35 \mathrm{E}-07$ & $4.33 \mathrm{E}-08$ & $0.3 \%$ & 5.5 & 23 & 5.5 & 22 & 16.3 \\
\hline 241-AP-101 & 8.10E-03 & $3.87 \mathrm{E}-07$ & $7.78 \mathrm{E}-08$ & $7.59 \mathrm{E}-09$ & $0.9 \%$ & 32.2 & 179 & 30.0 & 123 & 3.0 \\
\hline 241-AP-102 & $6.22 \mathrm{E}-03$ & $4.38 \mathrm{E}-07$ & $1.48 \mathrm{E}-07$ & $1.46 \mathrm{E}-08$ & $1.3 \%$ & 16.1 & 76 & 15.5 & 65 & 5.7 \\
\hline 241-AP-103 & $6.10 \mathrm{E}-03$ & $2.51 \mathrm{E}-07$ & $3.34 \mathrm{E}-07$ & $3.32 \mathrm{E}-08$ & $0.8 \%$ & 7.1 & 31 & 7.0 & 29 & 12.7 \\
\hline 241-AP-104 & $7.58 \mathrm{E}-03$ & $1.22 \mathrm{E}-07$ & $2.53 \mathrm{E}-07$ & $2.51 \mathrm{E}-08$ & $0.3 \%$ & 9.6 & 42 & 9.4 & 38 & 9.4 \\
\hline 241-AP-105 & $3.83 \mathrm{E}-03$ & $3.71 \mathrm{E}-07$ & $1.02 \mathrm{E}-07$ & $9.96 \mathrm{E}-09$ & $1.8 \%$ & 23.2 & 121 & 22.1 & 93 & 4.0 \\
\hline 241-AP-106 & $6.97 \mathrm{E}-03$ & $6.43 \mathrm{E}-08$ & $2.92 \mathrm{E}-07$ & $2.90 \mathrm{E}-08$ & $0.2 \%$ & 8.4 & 36 & 8.2 & 33 & 10.8 \\
\hline 24]-AP-107 & $8.59 \mathrm{E}-03$ & $9.71 \mathrm{E}-07$ & $1.33 \mathrm{E}-07$ & $1.31 \mathrm{E}-08$ & $2.1 \%$ & 17.3 & 85 & 16.6 & 71 & 5.4 \\
\hline 241-AP-108 & $8.15 \mathrm{E}-03$ & $8.47 \mathrm{E}-07$ & $1.59 \mathrm{E}-07$ & $1.58 \mathrm{E}-08$ & $1.9 \%$ & 14.4 & 69 & 14.0 & 59 & 6.4 \\
\hline 241-AW-101 & $5.51 \mathrm{E}-03$ & $1.04 \mathrm{E}-08$ & $1.01 \mathrm{E}-07$ & $9.89 \mathrm{E}-09$ & $0.0 \%$ & 25.3 & 125 & 23.9 & 96 & 3.7 \\
\hline 241-AW-102 & $8.68 \mathrm{E}-03$ & $6.29 \mathrm{E}-08$ & $1.38 \mathrm{E}-07$ & $1.37 \mathrm{E}-08$ & $0.1 \%$ & 18.0 & 83 & 17.3 & 70 & 5.1 \\
\hline 241-AW-103 & $4.45 \mathrm{E}-03$ & $5.67 \mathrm{E}-07$ & $1.51 \mathrm{E}-07$ & $1.49 \mathrm{E}-08$ & $2.3 \%$ & 15.0 & 73 & 14.5 & 62 & 6.1 \\
\hline 241-AW-104 & $7.03 \mathrm{E}-03$ & $1.60 \mathrm{E}-07$ & $2.27 \mathrm{E}-07$ & $2.25 \mathrm{E}-08$ & $0.4 \%$ & 10.7 & 47 & 10.5 & 42 & 8.5 \\
\hline 241-AW-105 & $1.08 \mathrm{E}-02$ & $7.23 \mathrm{E}-07$ & $3.40 \mathrm{E}-08$ & $3.20 \mathrm{E}-09$ & $1.2 \%$ & 80.8 & not occur & 67.8 & 282 & 1.3 \\
\hline 241-AW-106 & $6.66 \mathrm{E}-03$ & $3.45 \mathrm{E}-07$ & $1.07 \mathrm{E}-07$ & $1.05 \mathrm{E}-08$ & $0.9 \%$ & 22.7 & 114 & 21.6 & 89 & 4.1 \\
\hline 241-AY-101 & $3.90 \mathrm{E}-03$ & $1.29 \mathrm{E}-07$ & $8.43 \mathrm{E}-08$ & $8.24 \mathrm{E}-09$ & $0.6 \%$ & 29.9 & 159 & 27.9 & 114 & 2.9 \\
\hline 241-AY-102 & $6.80 \mathrm{E}-03$ & $7.09 \mathrm{E}-08$ & $3.53 \mathrm{E}-08$ & 3.34E-09 & $0.2 \%$ & 81.2 & not occur & 68.0 & 274 & 1.3 \\
\hline 241-AZ-101 & $7.07 \mathrm{E}-03$ & $1.18 \mathrm{E}-07$ & $7.45 \mathrm{E}-08$ & $7.26 \mathrm{E}-09$ & $0.3 \%$ & 34.5 & 193 & 32.0 & 129 & 2.8 \\
\hline 241-AZ-102 & $4.52 \mathrm{E}-03$ & $4.83 \mathrm{E}-07$ & $3.08 \mathrm{E}-07$ & $3.06 \mathrm{E}-08$ & $1.95 \%$ & 7.3 & 33 & 7.2 & 31 & 12.3 \\
\hline 241-SY-101 & $7.85 \mathrm{E}-03$ & $9.37 \mathrm{E}-07$ & $1.02 \mathrm{E}-07$ & $9.99 \mathrm{E}-09$ & $2.17 \%$ & 22.8 & 120 & 21.6 & 93 & 4.1 \\
\hline 241-SY-102 & $1.04 \mathrm{E}-02$ & $8.50 \mathrm{E}-07$ & $6.11 \mathrm{E}-08$ & 5.92E-09 & $1.49 \%$ & 40.7 & 268 & 37.2 & 156 & 2.4 \\
\hline 241-SY-103 & $6.75 \mathrm{E}-03$ & $1.25 \mathrm{E}-06$ & $2.58 \mathrm{E}-07$ & $2.56 \mathrm{E}-08$ & $3.36 \%$ & 8.2 & 39 & 8.1 & 36 & 11.0 \\
\hline
\end{tabular}

Notes:

In this calculation, $30 \%$ of the raw waste concentrations is ammonia, while hydrogen uses data in the targeted SpG.

It covers the off-normal condition when it occurred (i.e., lost vacuum and vent) while the process is running steadily or the process is finished.

BB = barometric breathing.

$\mathrm{LFL}=$ lower flammability limit. 
Table B-5. Time to Lower Flammability Limit for Evaporator Vessel C-A-1 with $62 \%$ Filled at SpG 1.5, Temperature of $150^{\circ} \mathrm{F}, 30 \% \mathrm{NH}_{3}$.

\begin{tabular}{|c|c|c|c|c|c|c|c|c|c|c|}
\hline Tanks & $\begin{array}{c}\text { Ammonia } \\
\text { transport } \\
\text { constant } \\
\text { k1 } \\
(\text { min-1) }\end{array}$ & $\begin{array}{c}\text { Ammonia } \\
\text { transport } \\
\text { constant } \\
\mathbf{k} 2 \\
(\mathrm{M} / \mathrm{min})\end{array}$ & $\begin{array}{c}\mathrm{UH}_{2} \\
\text { hydrogen } \\
\text { unit rate } \\
\text { (mole/m } \\
\text { per sec) }\end{array}$ & $\begin{array}{c}\mathrm{UCH}_{4} \\
\text { methane } \\
\text { unit rate } \\
\text { (mole/m³ } \\
\text { per sec) }\end{array}$ & $\begin{array}{c}\text { Steady- } \\
\text { state } \\
\mathrm{NH}_{3} \\
\mathrm{LFL} \\
(\%)\end{array}$ & $\begin{array}{c}\text { Time to } \\
\text { reach } \\
25 \% \\
\text { LFL at } \\
\text { BB vent } \\
\text { (days) }\end{array}$ & $\begin{array}{l}\text { Time to } \\
\text { reach } \\
100 \% \\
\text { LFL at } \\
\text { BB vent } \\
\text { (days) }\end{array}$ & $\begin{array}{c}\text { Time to } \\
\text { reach } \\
25 \% \\
\text { LFL at } \\
\text { zero } \\
\text { vent } \\
\text { (days) }\end{array}$ & $\begin{array}{l}\text { Time to } \\
\text { reach } \\
100 \% \\
\text { LFL at } \\
\text { zero vent } \\
\text { (days) }\end{array}$ & $\begin{array}{c}\text { Vent } \\
\text { rate } \\
\text { keep } \\
\text { below } \\
25 \% \\
\text { LFL } \\
\text { (cfh) }\end{array}$ \\
\hline $241-\mathrm{AN}-101$ & $7.13 \mathrm{E}-03$ & $1.59 \mathrm{E}-07$ & $3.22 \mathrm{E}-07$ & $3.20 \mathrm{E}-08$ & $0.4 \%$ & 7.4 & 31 & 7.2 & 29 & 12.3 \\
\hline $241-\mathrm{AN}-102$ & $7.75 \mathrm{E}-03$ & $1.90 \mathrm{E}-07$ & $1.36 \mathrm{E}-06$ & $1.36 \mathrm{E}-07$ & $0.5 \%$ & 1.7 & 7 & 1.7 & 7 & 52.1 \\
\hline 241-AN-103 & $5.08 \mathrm{E}-03$ & $3.69 \mathrm{E}-07$ & $1.94 \mathrm{E}-07$ & $1.92 \mathrm{E}-08$ & $1.3 \%$ & 11.9 & 54 & 11.6 & 48 & 7.7 \\
\hline 241-AN-104 & $3.43 \mathrm{E}-03$ & $2.88 \mathrm{E}-07$ & $2.79 \mathrm{E}-07$ & $2.77 \mathrm{E}-08$ & $1.6 \%$ & 8.1 & 36 & 8.0 & 33 & 11.2 \\
\hline 241-AN-105 & $4.00 \mathrm{E}-03$ & $2.38 \mathrm{E}-07$ & $2.29 \mathrm{E}-07$ & $2.27 \mathrm{E}-08$ & $1.1 \%$ & 10.1 & 45 & 9.9 & 41 & 9.0 \\
\hline 241-AN-106 & $6.48 \mathrm{E}-03$ & $2.06 \mathrm{E}-07$ & 4.47E-07 & $4.45 \mathrm{E}-08$ & $0.6 \%$ & 5.2 & 22 & 5.2 & 21 & 17.2 \\
\hline 241-AN-107 & $8.94 \mathrm{E}-03$ & $1.74 \mathrm{E}-07$ & $7.04 \mathrm{E}-07$ & $7.02 \mathrm{E}-08$ & $0.4 \%$ & 3.3 & 14 & 3.3 & 13 & 26.8 \\
\hline 241-AP-101 & $7.88 \mathrm{E}-03$ & $3.93 \mathrm{E}-07$ & $1.28 \mathrm{E}-07$ & $1.26 \mathrm{E}-08$ & $0.9 \%$ & 18.6 & 89 & 17.8 & 73 & 5.0 \\
\hline 241-AP-102 & $6.03 \mathrm{E}-03$ & $4.43 \mathrm{E}-07$ & $2.45 \mathrm{E}-07$ & $2.44 \mathrm{E}-08$ & $1.4 \%$ & 9.3 & 42 & 9.1 & 38 & 9.7 \\
\hline 241-AP-103 & $5.91 \mathrm{E}-03$ & $2.54 \mathrm{E}-07$ & $5.58 \mathrm{E}-07$ & $5.56 \mathrm{E}-08$ & $0.8 \%$ & 4.2 & 18 & 4.1 & 17 & 21.6 \\
\hline 241-AP-104 & $7.36 \mathrm{E}-03$ & $1.23 \mathrm{E}-07$ & $4.22 \mathrm{E}-07$ & $4.20 \mathrm{E}-08$ & $0.3 \%$ & 5.6 & 24 & 5.5 & 22 & 16.0 \\
\hline 241-AP-105 & $3.69 \mathrm{E}-03$ & $3.74 \mathrm{E}-07$ & $1.69 \mathrm{E}-07$ & $1.67 \mathrm{E}-08$ & $1.9 \%$ & 13.4 & 63 & 13.0 & 55 & 6.8 \\
\hline 241-AP-106 & $6.76 \mathrm{E}-03$ & $6.51 \mathrm{E}-08$ & $4.87 \mathrm{E}-07$ & $4.85 \mathrm{E}-08$ & $0.2 \%$ & 4.9 & 20 & 4.8 & 19 & 18.4 \\
\hline 241-AP-107 & $8.33 \mathrm{E}-03$ & $9.89 \mathrm{E}-07$ & $2.22 \mathrm{E}-07$ & $2.20 \mathrm{E}-08$ & $2.2 \%$ & 10.0 & 46 & 9.8 & 42 & 9.1 \\
\hline 241-AP-108 & $7.93 \mathrm{E}-03$ & $8.60 \mathrm{E}-07$ & $2.66 \mathrm{E}-07$ & $2.64 \mathrm{E}-08$ & $2.0 \%$ & 8.3 & 38 & 8.2 & 35 & 10.9 \\
\hline 241-AW-101 & $5.33 \mathrm{E}-03$ & $1.05 \mathrm{E}-08$ & $1.66 \mathrm{E}-07$ & $1.64 \mathrm{E}-08$ & $0.0 \%$ & 14.8 & 66 & 14.3 & 57 & 6.2 \\
\hline 241-AW-102 & $8.42 \mathrm{E}-03$ & $6.41 \mathrm{E}-08$ & $2.31 \mathrm{E}-07$ & $2.29 \mathrm{E}-08$ & $0.1 \%$ & 10.5 & 45 & 10.2 & 41 & 8.7 \\
\hline 241-AW-103 & $4.29 \mathrm{E}-03$ & $5.72 \mathrm{E}-07$ & $2.53 \mathrm{E}-07$ & $2.51 \mathrm{E}-08$ & $2.5 \%$ & 8.6 & 40 & 8.5 & 37 & 10.5 \\
\hline 241-AW-104 & $6.81 \mathrm{E}-03$ & $1.63 \mathrm{E}-07$ & $3.79 \mathrm{E}-07$ & $3.77 \mathrm{E}-08$ & $0.4 \%$ & 6.2 & 26 & 6.2 & 25 & 14.5 \\
\hline 241-AW-105 & $1.04 \mathrm{E}-02$ & $7.47 \mathrm{E}-07$ & $5.53 \mathrm{E}-08$ & $5.34 \mathrm{E}-09$ & $1.3 \%$ & 44.9 & 320 & 40.7 & 170 & 2.2 \\
\hline 241-AW-106 & $6.46 \mathrm{E}-03$ & $3.49 \mathrm{E}-07$ & $1.78 \mathrm{E}-07$ & $1.77 \mathrm{E}-08$ & $1.0 \%$ & 13.1 & 60 & 12.8 & 53 & 7.0 \\
\hline 241-AY-101 & $3.76 \mathrm{E}-03$ & $1.30 \mathrm{E}-07$ & $1.41 \mathrm{E}-07$ & $1.39 \mathrm{E}-08$ & $0.6 \%$ & 17.1 & 80 & 16.4 & 67 & 4.9 \\
\hline 241-AY-102 & $6.40 \mathrm{E}-03$ & $7.28 \mathrm{E}-08$ & $5.77 \mathrm{E}-08$ & $5.58 \mathrm{E}-09$ & $0.2 \%$ & 45.1 & 299 & 40.8 & 164 & 2.2 \\
\hline 241-AZ-101 & $6.84 \mathrm{E}-03$ & $1.20 \mathrm{E}-07$ & $9.71 \mathrm{E}-08$ & $9.52 \mathrm{E}-09$ & $0.3 \%$ & 25.5 & 128 & 24.1 & 97 & 3.7 \\
\hline 241-AZ-102 & $4.37 \mathrm{E}-03$ & 4.87E-07 & $4.33 \mathrm{E}-07$ & $4.31 \mathrm{E}-08$ & $2.1 \%$ & 5.1 & 23 & 5.0 & 21 & 17.7 \\
\hline 241-SY-101 & $7.63 \mathrm{E}-03$ & $9.51 \mathrm{E}-07$ & $1.69 \mathrm{E}-07$ & $1.67 \mathrm{E}-08$ & $2.3 \%$ & 13.1 & 63 & 12.7 & 55 & 7.0 \\
\hline 241-SY-102 & $1.01 \mathrm{E}-02$ & $8.70 \mathrm{E}-07$ & $1.01 \mathrm{E}-07$ & $9.92 \mathrm{E}-09$ & $1.6 \%$ & 23.1 & 119 & 22.0 & 92 & 4.0 \\
\hline $241-S Y-103$ & $6.54 \mathrm{E}-03$ & $1.26 \mathrm{E}-06$ & $4.28 \mathrm{E}-07$ & 4.27E-08 & $3.6 \%$ & 4.8 & 22 & 4.7 & 21 & 18.8 \\
\hline
\end{tabular}

Notes:

In this calculation, $30 \%$ of the raw waste concentrations is ammonia, while hydrogen uses data in the targeted SpG.

It covers the off-normal condition when it occurred (i.e., lost vacuum and vent) while the process is running steadily or the process is finished.

$\mathrm{BB}=$ barometric breathing.

LFL = lower flammability limit. 
Table B-6. Time to Lower Flammability Limit for Evaporator Vessel C-A-1 with $62 \%$ Filled at SpG 1.5, Temperature of $150^{\circ} \mathrm{F}, 100 \% \mathrm{NH}_{3}$.

\begin{tabular}{|c|c|c|c|c|c|c|c|c|c|c|}
\hline Tanks & $\begin{array}{c}\text { Ammonia } \\
\text { transport } \\
\text { constant } \\
\text { k1 } \\
(\min -1)\end{array}$ & $\begin{array}{c}\text { Ammonia } \\
\text { transport } \\
\text { constant } \\
\text { k2 } \\
(\mathrm{M} / \mathrm{min})\end{array}$ & $\begin{array}{c}\mathrm{UH}_{2} \\
\text { hydrogen } \\
\text { unit rate } \\
\left(\mathrm{mole} / \mathrm{m}^{3}\right. \\
\text { per sec) }\end{array}$ & $\begin{array}{c}\mathrm{UCH}_{4} \\
\text { methane } \\
\text { unit rate } \\
\left(\mathrm{mole} / \mathrm{m}^{3}\right. \\
\text { per sec) }\end{array}$ & $\begin{array}{c}\text { Steady- } \\
\text { state } \\
\mathrm{NH}_{3} \\
\text { LFL } \\
(\%)\end{array}$ & $\begin{array}{c}\text { Time } \\
\text { to } \\
\text { reach } \\
25 \% \\
\text { LFL at } \\
\text { BB } \\
\text { vent } \\
\text { (days) }\end{array}$ & $\begin{array}{c}\text { Time to } \\
\text { reach } \\
100 \% \\
\text { LFL at } \\
\text { BB vent } \\
\text { (days) }\end{array}$ & $\begin{array}{l}\text { Time to } \\
\text { reach } \\
25 \% \\
\text { LFL at } \\
\text { zero vent } \\
\text { (days) }\end{array}$ & $\begin{array}{l}\text { Time to } \\
\text { reach } \\
100 \% \\
\text { LFL at } \\
\text { zero vent } \\
\text { (days) }\end{array}$ & $\begin{array}{c}\text { Vent } \\
\text { rate } \\
\text { keep } \\
\text { below } \\
25 \% \\
\text { LFL } \\
\text { (cfh) }\end{array}$ \\
\hline 241-AN-101 & $7.13 \mathrm{E}-03$ & $5.29 \mathrm{E}-07$ & $3.22 \mathrm{E}-07$ & $3.20 \mathrm{E}-08$ & $1.4 \%$ & 7.1 & 31 & 7.0 & 29 & 12.8 \\
\hline $241-\mathrm{AN}-102$ & $7.75 \mathrm{E}-03$ & $6.33 \mathrm{E}-07$ & $1.36 \mathrm{E}-06$ & $1.36 \mathrm{E}-07$ & $1.5 \%$ & 1.6 & 7 & 1.6 & 7 & 54.5 \\
\hline 241-AN-103 & $5.08 \mathrm{E}-03$ & $1.23 \mathrm{E}-06$ & $1.94 \mathrm{E}-07$ & $1.92 \mathrm{E}-08$ & $4.5 \%$ & 10.3 & 52 & 10.0 & 47 & 8.9 \\
\hline $241-\mathrm{AN}-104$ & $3.43 \mathrm{E}-03$ & $9.60 \mathrm{E}-07$ & $2.79 \mathrm{E}-07$ & $2.77 \mathrm{E}-08$ & $5.2 \%$ & 6.8 & 35 & 6.7 & 32 & 13.2 \\
\hline 241-AN-105 & $4.00 \mathrm{E}-03$ & $7.95 \mathrm{E}-07$ & $2.29 \mathrm{E}-07$ & $2.27 \mathrm{E}-08$ & $3.7 \%$ & 9.0 & 44 & 8.8 & 40 & 10.1 \\
\hline 241-AN-106 & $6.48 \mathrm{E}-03$ & $6.87 \mathrm{E}-07$ & 4.47E-07 & $4.45 \mathrm{E}-08$ & $2.0 \%$ & 4.9 & 22 & 4.9 & 21 & 18.2 \\
\hline 241-AN-107 & $8.94 \mathrm{E}-03$ & $5.81 \mathrm{E}-07$ & $7.04 \mathrm{E}-07$ & $7.02 \mathrm{E}-08$ & $1.2 \%$ & 3.2 & 14 & 3.2 & 13 & 27.8 \\
\hline 241-AP-101 & $7.88 \mathrm{E}-03$ & $1.31 \mathrm{E}-06$ & $1.28 \mathrm{E}-07$ & $1.26 \mathrm{E}-08$ & $3.1 \%$ & 16.9 & 87 & 16.2 & 72 & 5.5 \\
\hline 241-AP-102 & $6.03 \mathrm{E}-03$ & $1.48 \mathrm{E}-06$ & $2.45 \mathrm{E}-07$ & $2.44 \mathrm{E}-08$ & $4.5 \%$ & 8.1 & 40 & 7.9 & 37 & 11.3 \\
\hline 241-AP-103 & $5.91 \mathrm{E}-03$ & $8.48 \mathrm{E}-07$ & $5.58 \mathrm{E}-07$ & $5.56 \mathrm{E}-08$ & $2.7 \%$ & 3.8 & 17 & 3.8 & 17 & 23.4 \\
\hline 241-AP-104 & $7.36 \mathrm{E}-03$ & $4.11 \mathrm{E}-07$ & 4.22E-07 & $4.20 \mathrm{E}-08$ & $1.0 \%$ & 5.4 & 23 & 5.4 & 22 & 16.5 \\
\hline 241-AP-105 & $3.69 \mathrm{E}-03$ & $1.25 \mathrm{E}-06$ & $1.69 \mathrm{E}-07$ & $1.67 \mathrm{E}-08$ & $6.3 \%$ & 10.8 & 60 & 10.5 & 53 & 8.4 \\
\hline 241-AP-106 & $6.76 \mathrm{E}-03$ & $2.17 \mathrm{E}-07$ & 4.87E-07 & $4.85 \mathrm{E}-08$ & $0.6 \%$ & 4.8 & 20 & 4.8 & 19 & 18.7 \\
\hline 241-AP-107 & $8.33 \mathrm{E}-03$ & $3.30 \mathrm{E}-06$ & $2.22 \mathrm{E}-07$ & $2.20 \mathrm{E}-08$ & $7.3 \%$ & 7.7 & 44 & 7.6 & 40 & 11.8 \\
\hline $241-\mathrm{AP}-108$ & $7.93 \mathrm{E}-03$ & $2.87 \mathrm{E}-06$ & $2.66 \mathrm{E}-07$ & $2.64 \mathrm{E}-08$ & $6.7 \%$ & 6.6 & 36 & 6.5 & 33 & 13.7 \\
\hline 241-AW-101 & $5.33 \mathrm{E}-03$ & $3.51 \mathrm{E}-08$ & $1.66 \mathrm{E}-07$ & $1.64 \mathrm{E}-08$ & $0.1 \%$ & 14.7 & 66 & 14.2 & 57 & 6.2 \\
\hline 241-AW-102 & $8.42 \mathrm{E}-03$ & $2.14 \mathrm{E}-07$ & $2.31 \mathrm{E}-07$ & $2.29 \mathrm{E}-08$ & $0.5 \%$ & 10.3 & 45 & 10.1 & 41 & 8.8 \\
\hline $241-A W-103$ & $4.29 \mathrm{E}-03$ & $1.91 \mathrm{E}-06$ & $2.53 \mathrm{E}-07$ & $2.51 \mathrm{E}-08$ & $8.2 \%$ & 6.4 & 37 & 6.3 & 34 & 14.1 \\
\hline 241-AW-104 & $6.81 \mathrm{E}-03$ & $5.42 \mathrm{E}-07$ & $3.79 \mathrm{E}-07$ & $3.77 \mathrm{E}-08$ & $1.5 \%$ & 6.0 & 26 & 5.9 & 25 & 15.1 \\
\hline 24l-AW-105 & $1.04 \mathrm{E}-02$ & $2.49 \mathrm{E}-06$ & $5.53 \mathrm{E}-08$ & $5.34 \mathrm{E}-09$ & $4.4 \%$ & 38.5 & 299 & 35.4 & 164 & 2.5 \\
\hline 241-AW-106 & $6.46 \mathrm{E}-03$ & $1.16 \mathrm{E}-06$ & $1.78 \mathrm{E}-07$ & $1.77 \mathrm{E}-08$ & $3.3 \%$ & 11.8 & 58 & 11.5 & 51 & 7.7 \\
\hline 241-AY-101 & $3.76 \mathrm{E}-03$ & $4.33 \mathrm{E}-07$ & $1.41 \mathrm{E}-07$ & $1.39 \mathrm{E}-08$ & $2.1 \%$ & 16.0 & 78 & 15.4 & 66 & 5.2 \\
\hline 241-AY-102 & $6.40 \mathrm{E}-03$ & $2.43 \mathrm{E}-07$ & $5.77 \mathrm{E}-08$ & $5.58 \mathrm{E}-09$ & $0.7 \%$ & 44.1 & 296 & 40.0 & 164 & 2.2 \\
\hline 241-AZ-101 & $6.84 \mathrm{E}-03$ & $4.00 \mathrm{E}-07$ & $9.71 \mathrm{E}-08$ & $9.52 \mathrm{E}-09$ & $1.1 \%$ & 24.7 & 127 & 23.4 & 97 & 3.8 \\
\hline $241-A Z-102$ & $4.37 \mathrm{E}-03$ & $1.62 \mathrm{E}-06$ & 4.33E-07 & $4.31 \mathrm{E}-08$ & $6.9 \%$ & 4.0 & 21 & 4.0 & 20 & 22.4 \\
\hline 241-SY-101 & $7.63 \mathrm{E}-03$ & $3.17 \mathrm{E}-06$ & $1.69 \mathrm{E}-07$ & $1.67 \mathrm{E}-08$ & $7.7 \%$ & 9.9 & 59 & 9.7 & 52 & 9.2 \\
\hline $241-S Y-102$ & $1.01 \mathrm{E}-02$ & $2.90 \mathrm{E}-06$ & $1.01 \mathrm{E}-07$ & $9.92 \mathrm{E}-09$ & $5.3 \%$ & 19.3 & 114 & 18.5 & 89 & 4.8 \\
\hline 241-SY-103 & $6.54 \mathrm{E}-03$ & $4.21 \mathrm{E}-06$ & $4.28 \mathrm{E}-07$ & 4.27E-08 & $11.9 \%$ & 2.9 & 20 & 2.9 & 19 & 30.7 \\
\hline
\end{tabular}

Notes:

In this calculation, $100 \%$ of the raw waste concentrations is ammonia, while hydrogen uses data in the targeted SpG.

It covers the off-normal condition when it occurred (i.e., lost vacuum and vent) while the process is running steadily or the process is finished.

$\mathrm{BB}=$ barometric breathing.

LFL = lower flammability limit. 
Table B-7. Time to Lower Flammability Limit for Evaporator Vessel C-A-1 with $62 \%$ Filled at SpG 1.6, Temperature of $150^{\circ} \mathrm{F}, 100 \% \mathrm{NH}_{3}$.

\begin{tabular}{|c|c|c|c|c|c|c|c|c|c|c|}
\hline Tanks & $\begin{array}{c}\text { Ammonia } \\
\text { transport } \\
\text { constant } \\
\text { k1 } \\
(\mathrm{min}-1)\end{array}$ & $\begin{array}{c}\text { Ammonia } \\
\text { transport } \\
\text { constant } \\
\text { k2 } \\
(\mathrm{M} / \mathrm{min})\end{array}$ & $\begin{array}{c}\mathrm{UH}_{2} \\
\text { hydrogen } \\
\text { unit rate } \\
\left(\mathrm{mole} / \mathrm{m}^{3}\right. \\
\text { per sec) }\end{array}$ & $\begin{array}{c}\mathrm{UCH}_{4} \\
\text { methane } \\
\text { unit rate } \\
\text { (mole/m } \\
\text { per sec) }\end{array}$ & $\begin{array}{c}\text { Steady- } \\
\text { state } \\
\mathrm{NH}_{3} \\
\mathbf{L F L} \\
(\%)\end{array}$ & $\begin{array}{c}\text { Time to } \\
\text { reach } \\
25 \% \\
\text { LFL at } \\
\text { BB vent } \\
\text { (days) }\end{array}$ & $\begin{array}{c}\text { Time to } \\
\text { reach } \\
100 \% \\
\text { LFL at } \\
\text { BB vent } \\
\text { (days) }\end{array}$ & $\begin{array}{c}\text { Time to } \\
\text { reach } \\
25 \% \text { LFL } \\
\text { at zero } \\
\text { vent } \\
\text { (days) }\end{array}$ & $\begin{array}{l}\text { Time to } \\
\text { reach } \\
100 \% \\
\text { LFL at } \\
\text { zero vent } \\
\text { (days) }\end{array}$ & 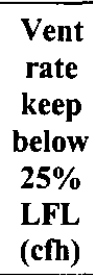 \\
\hline 241-AN-101 & $5.19 \mathrm{E}-03$ & $6.09 \mathrm{E}-07$ & $4.05 \mathrm{E}-07$ & $4.03 \mathrm{E}-08$ & $2.2 \%$ & 5.4 & 24 & 5.3 & 23 & 16.6 \\
\hline $241-\mathrm{AN}-102$ & $5.81 \mathrm{E}-03$ & $7.32 \mathrm{E}-07$ & $1.72 \mathrm{E}-06$ & $1.72 \mathrm{E}-07$ & $2.3 \%$ & 1.3 & 5 & 1.2 & 5 & 71.3 \\
\hline 241-AN-103 & $3.30 \mathrm{E}-03$ & $1.39 \mathrm{E}-06$ & $2.43 \mathrm{E}-07$ & $2.41 \mathrm{E}-08$ & $7.8 \%$ & 6.8 & 39 & 6.7 & 36 & 13.3 \\
\hline 241-AN-104 & $1.97 \mathrm{E}-03$ & $1.06 \mathrm{E}-06$ & $3.51 \mathrm{E}-07$ & $3.49 \mathrm{E}-08$ & $9.9 \%$ & 4.1 & 26 & 4.1 & 24 & 21.8 \\
\hline 241-AN-105 & $2.41 \mathrm{E}-03$ & $8.82 \mathrm{E}-07$ & $2.88 \mathrm{E}-07$ & $2.86 \mathrm{E}-08$ & $6.8 \%$ & 6.1 & 33 & 6.0 & 31 & 14.8 \\
\hline 241-AN-106 & $4.90 \mathrm{E}-03$ & $7.72 \mathrm{E}-07$ & $5.62 \mathrm{E}-07$ & $5.60 \mathrm{E}-08$ & $2.9 \%$ & 3.7 & 17 & 3.7 & 16 & 23.9 \\
\hline $241-\mathrm{AN}-107$ & $7.26 \mathrm{E}-03$ & $6.68 \mathrm{E}-07$ & $8.95 \mathrm{E}-07$ & $8.93 \mathrm{E}-08$ & $1.7 \%$ & 2.5 & 11 & 2.5 & 10 & 36.0 \\
\hline 241-AP-101 & $5.94 \mathrm{E}-03$ & $1.52 \mathrm{E}-06$ & $1.60 \mathrm{E}-07$ & $1.58 \mathrm{E}-08$ & $4.7 \%$ & 12.3 & 65 & 12.0 & 56 & 7.4 \\
\hline 241-AP-102 & $4.14 \mathrm{E}-03$ & $1.68 \mathrm{E}-06$ & $3.08 \mathrm{E}-07$ & $3.06 \mathrm{E}-08$ & $7.5 \%$ & 5.4 & 30 & 5.4 & 28 & 16.5 \\
\hline 241-AP-103 & $4.03 \mathrm{E}-03$ & $9.65 \mathrm{E}-07$ & $7.02 \mathrm{E}-07$ & $7.00 \mathrm{E}-08$ & $4.4 \%$ & 2.8 & 13 & 2.8 & 13 & 32.0 \\
\hline 241-AP-104 & $5.48 \mathrm{E}-03$ & $4.73 \mathrm{E}-07$ & $5.31 \mathrm{E}-07$ & $5.29 \mathrm{E}-08$ & $1.6 \%$ & 4.2 & 18 & 4.2 & 18 & 21.3 \\
\hline 241-AP-105 & $2.17 \mathrm{E}-03$ & $1.38 \mathrm{E}-06$ & $2.11 \mathrm{E}-07$ & $2.10 \mathrm{E}-08$ & $11.8 \%$ & 6.0 & 44 & 5.9 & 40 & 15.0 \\
\hline 241-AP-106 & $5.00 \mathrm{E}-03$ & $2.47 \mathrm{E}-07$ & $6.12 \mathrm{E}-07$ & $6.11 \mathrm{E}-08$ & $0.9 \%$ & 3.8 & 16 & 3.7 & 15 & 23.9 \\
\hline 241-AP-107 & $7.08 \mathrm{E}-03$ & $3.67 \mathrm{E}-06$ & $2.78 \mathrm{E}-07$ & $2.76 \mathrm{E}-08$ & $9.6 \%$ & 5.3 & 33 & 5.2 & 31 & 17.0 \\
\hline 241-AP-108 & $6.06 \mathrm{E}-03$ & $3.31 \mathrm{E}-06$ & $3.34 \mathrm{E}-07$ & $3.33 \mathrm{E}-08$ & $10.1 \%$ & 4.3 & 27 & 4.2 & 25 & 21.1 \\
\hline 241-AW-101 & $3.51 \mathrm{E}-03$ & $3.97 \mathrm{E}-08$ & $2.08 \mathrm{E}-07$ & $2.06 \mathrm{E}-08$ & $0.2 \%$ & 11.6 & 51 & 11.3 & 46 & 7.8 \\
\hline 241-AW-102 & $7.10 \mathrm{E}-03$ & $2.39 \mathrm{E}-07$ & $2.89 \mathrm{E}-07$ & $2.88 \mathrm{E}-08$ & $0.6 \%$ & 8.1 & 35 & 8.0 & 33 & 11.1 \\
\hline 241-AW-103 & $2.64 \mathrm{E}-03$ & $2.13 \mathrm{E}-06$ & $3.18 \mathrm{E}-07$ & $3.16 \mathrm{E}-08$ & $14.9 \%$ & 3.0 & 27 & 3.0 & 25 & 29.5 \\
\hline 241-AW-104 & $5.11 \mathrm{E}-03$ & $6.14 \mathrm{E}-07$ & $4.76 \mathrm{E}-07$ & $4.74 \mathrm{E}-08$ & $2.2 \%$ & 4.6 & 20 & 4.5 & 19 & 19.6 \\
\hline 241-AW-105 & $1.03 \mathrm{E}-02$ & $2.57 \mathrm{E}-06$ & $6.89 \mathrm{E}-08$ & $6.70 \mathrm{E}-09$ & $4.6 \%$ & 30.0 & 199 & 28.1 & 131 & 3.2 \\
\hline 241-AW-106 & $4.54 \mathrm{E}-03$ & $1.33 \mathrm{E}-06$ & $2.24 \mathrm{E}-07$ & $2.22 \mathrm{E}-08$ & $5.4 \%$ & 8.5 & 44 & 8.3 & 40 & 10.7 \\
\hline 241-AY-101 & $2.22 \mathrm{E}-03$ & $4.79 \mathrm{E}-07$ & $1.77 \mathrm{E}-07$ & $1.75 \mathrm{E}-08$ & $4.0 \%$ & 11.6 & 59 & 11.3 & 52 & 7.1 \\
\hline $241-\mathrm{AY}-102$ & $5.63 \mathrm{E}-03$ & $2.60 \mathrm{E}-07$ & $7.18 \mathrm{E}-08$ & $6.99 \mathrm{E}-09$ & $0.9 \%$ & 34.5 & 198 & 31.9 & 131 & 2.8 \\
\hline $241-\mathrm{AZ}-101$ & $5.33 \mathrm{E}-03$ & $4.48 \mathrm{E}-07$ & $1.13 \mathrm{E}-07$ & $1.11 \mathrm{E}-08$ & $1.6 \%$ & 20.7 & 104 & 19.8 & 83 & 4.5 \\
\hline $241-\mathrm{AZ}-102$ & $2.70 \mathrm{E}-03$ & $1.81 \mathrm{E}-06$ & $5.55 \mathrm{E}-07$ & $5.53 \mathrm{E}-08$ & $12.4 \%$ & 2.1 & 15 & 2.1 & 15 & 41.4 \\
\hline $241-S Y-101$ & $5.69 \mathrm{E}-03$ & $3.67 \mathrm{E}-06$ & $2.12 \mathrm{E}-07$ & $2.10 \mathrm{E}-08$ & $11.9 \%$ & 5.9 & 43 & 5.8 & 39 & 15.2 \\
\hline 241-SY-102 & $9.14 \mathrm{E}-03$ & $3.20 \mathrm{E}-06$ & $1.27 \mathrm{E}-07$ & $1.25 \mathrm{E}-08$ & $6.5 \%$ & 14.3 & 84 & 13.9 & 70 & 6.4 \\
\hline $241-S Y-103$ & 4.62E- 03 & $4.82 \mathrm{E}-06$ & $5.39 \mathrm{E}-07$ & $5.37 \mathrm{E}-08$ & $19.3 \%$ & 1.0 & 15 & 1.0 & 14 & 89.0 \\
\hline
\end{tabular}

Notes:

In this calculation, $100 \%$ of the raw waste concentrations is ammonia, while hydrogen uses data in the targeted SpG.

It covers the off-normal condition when it occurred (i.e., lost vacuum and vent) while the process is running steadily or the process is finished.

$\mathrm{BB}=$ barometric breathing.

LFL = lower flammability limit. 
Table B-8. Time to Lower Flammability Limit for Evaporator Vessel C-A-1 with $62 \%$ Filled at SpG 1.6, Temperature of $150^{\circ} \mathrm{F}, 30 \% \mathrm{NH}_{3}$.

\begin{tabular}{|c|c|c|c|c|c|c|c|c|c|c|}
\hline Tanks & $\begin{array}{c}\text { Ammonia } \\
\text { transport } \\
\text { constant } \\
\text { k1 } \\
(\text { min-1) }\end{array}$ & $\begin{array}{c}\text { Ammonia } \\
\text { transport } \\
\text { constant } \\
\text { k2 } \\
(M / \mathrm{min})\end{array}$ & $\begin{array}{c}\mathrm{UH}_{2} \\
\text { hydrogen } \\
\text { unit rate } \\
\text { (mole/m³ } \\
\text { per sec) }\end{array}$ & $\begin{array}{c}\mathrm{UCH}_{4} \\
\text { methane } \\
\text { unit rate } \\
\text { (mole/m } \\
\text { per sec) }\end{array}$ & $\begin{array}{c}\text { Steady- } \\
\text { state } \\
\mathrm{NH}_{3} \\
\mathrm{LFL} \\
(\%)\end{array}$ & $\begin{array}{l}\text { Time to } \\
\text { reach } \\
25 \% \\
\text { LFL at } \\
\text { BB vent } \\
\text { (days) }\end{array}$ & $\begin{array}{c}\text { Time to } \\
\text { reach } \\
100 \% \\
\text { LFL at } \\
\text { BB vent } \\
\text { (days) }\end{array}$ & $\begin{array}{l}\text { Time to } \\
\text { reach } \\
25 \% \\
\text { LFL at } \\
\text { zero } \\
\text { vent } \\
\text { (days) }\end{array}$ & $\begin{array}{l}\text { Time to } \\
\text { reach } \\
100 \% \\
\text { LFL at } \\
\text { zero } \\
\text { vent } \\
\text { (days) }\end{array}$ & $\begin{array}{c}\begin{array}{c}\text { Vent } \\
\text { rate keep } \\
\text { below }\end{array} \\
25 \% \\
\text { LFL } \\
\text { (cfh) }\end{array}$ \\
\hline 241-AN-101 & $5.19 \mathrm{E}-03$ & $1.83 \mathrm{E}-07$ & $4.05 \mathrm{E}-07$ & $4.03 \mathrm{E}-08$ & $0.7 \%$ & 5.8 & 25 & 5.7 & 23 & 15.6 \\
\hline 241-AN-102 & $5.81 \mathrm{E}-03$ & $2.20 \mathrm{E}-07$ & $1.72 \mathrm{E}-06$ & $1.72 \mathrm{E}-07$ & $0.7 \%$ & 1.3 & 6 & 1.3 & 5 & 66.5 \\
\hline 241-AN-103 & $3.30 \mathrm{E}-03$ & $4.16 \mathrm{E}-07$ & $2.43 \mathrm{E}-07$ & $2.41 \mathrm{E}-08$ & $2.3 \%$ & 9.0 & 42 & 8.8 & 38 & 10.1 \\
\hline $24 \mathrm{l}-\mathrm{AN}-104$ & $1.97 \mathrm{E}-03$ & $3.17 \mathrm{E}-07$ & $3.51 \mathrm{E}-07$ & $3.49 \mathrm{E}-08$ & $3.0 \%$ & 6.0 & 28 & 6.0 & 26 & 14.9 \\
\hline 241-AN-105 & $2.41 \mathrm{E}-03$ & $2.65 \mathrm{E}-07$ & $2.88 \mathrm{E}-07$ & $2.86 \mathrm{E}-08$ & $2.0 \%$ & 7.7 & 35 & 7.6 & 32 & 11.7 \\
\hline 241-AN-106 & $4.90 \mathrm{E}-03$ & $2.32 \mathrm{E}-07$ & $5.62 \mathrm{E}-07$ & $5.60 \mathrm{E}-08$ & $0.9 \%$ & 4.1 & 17 & 4.1 & 17 & 21.9 \\
\hline 241-AN-107 & $7.26 \mathrm{E}-03$ & $2.00 \mathrm{E}-07$ & $8.95 \mathrm{E}-07$ & $8.93 \mathrm{E}-08$ & $0.5 \%$ & 2.6 & 11 & 2.6 & 11 & 34.3 \\
\hline 241-AP-101 & $5.94 \mathrm{E}-03$ & $4.56 \mathrm{E}-07$ & $1.60 \mathrm{E}-07$ & $1.58 \mathrm{E}-08$ & $1.4 \%$ & 14.4 & 68 & 14.0 & 58 & 6.4 \\
\hline 241-AP-102 & 4.14E-03 & $5.05 \mathrm{E}-07$ & $3.08 \mathrm{E}-07$ & $3.06 \mathrm{E}-08$ & $2.3 \%$ & 7.1 & 32 & 7.0 & 30 & 12.7 \\
\hline 241-AP-103 & $4.03 \mathrm{E}-03$ & $2.90 \mathrm{E}-07$ & $7.02 \mathrm{E}-07$ & $7.00 \mathrm{E}-08$ & $1.3 \%$ & 3.2 & 14 & 3.2 & 13 & 27.8 \\
\hline 241-AP-104 & $5.48 \mathrm{E}-03$ & $1.42 \mathrm{E}-07$ & $5.31 \mathrm{E}-07$ & $5.29 \mathrm{E}-08$ & $0.5 \%$ & 4.4 & 19 & 4.4 & 18 & 20.3 \\
\hline 241-AP-105 & $2.17 \mathrm{E}-03$ & $4.13 \mathrm{E}-07$ & $2.11 \mathrm{E}-07$ & $2.10 \mathrm{E}-08$ & $3.5 \%$ & 9.8 & 48 & 9.6 & 43 & 9.2 \\
\hline 241-AP-106 & $5.00 \mathrm{E}-03$ & $7.41 \mathrm{E}-08$ & $6.12 \mathrm{E}-07$ & $6.11 \mathrm{E}-08$ & $0.3 \%$ & 3.9 & 16 & 3.8 & 15 & 23.2 \\
\hline 241-AP-107 & $7.08 \mathrm{E}-03$ & $1.10 \mathrm{E}-06$ & $2.78 \mathrm{E}-07$ & $2.76 \mathrm{E}-08$ & $2.9 \%$ & 7.7 & 36 & 7.5 & 33 & 11.8 \\
\hline 241-AP-108 & $6.06 \mathrm{E}-03$ & $9.92 \mathrm{E}-07$ & $3.34 \mathrm{E}-07$ & $3.33 \mathrm{E}-08$ & $3.0 \%$ & 6.3 & 29 & 6.2 & 27 & 14.3 \\
\hline 241-AW-101 & $3.51 \mathrm{E}-03$ & $1.19 \mathrm{E}-08$ & $2.08 \mathrm{E}-07$ & $2.06 \mathrm{E}-08$ & $0.1 \%$ & 11.7 & 51 & 11.4 & 46 & 7.8 \\
\hline 241-AW-102 & $7.10 \mathrm{E}-03$ & $7.17 \mathrm{E}-08$ & $2.89 \mathrm{E}-07$ & $2.88 \mathrm{E}-08$ & $0.2 \%$ & 8.3 & 35 & 8.1 & 33 & 10.9 \\
\hline 241-AW-103 & $2.64 \mathrm{E}-03$ & $6.38 \mathrm{E}-07$ & $3.18 \mathrm{E}-07$ & $3.16 \mathrm{E}-08$ & $4.5 \%$ & 6.2 & 31 & 6.1 & 29 & 14.5 \\
\hline 241-AW-104 & $5.11 \mathrm{E}-03$ & $1.84 \mathrm{E}-07$ & $4.76 \mathrm{E}-07$ & $4.74 \mathrm{E}-08$ & $0.7 \%$ & 4.9 & 21 & 4.8 & 20 & 18.4 \\
\hline 241-AW-105 & $1.03 \mathrm{E}-02$ & $7.71 \mathrm{E}-07$ & $6.89 \mathrm{E}-08$ & $6.70 \mathrm{E}-09$ & $1.4 \%$ & 35.2 & 210 & 32.5 & 136 & 2.7 \\
\hline $241-\mathrm{AW}-106$ & $4.54 \mathrm{E}-03$ & $4.00 \mathrm{E}-07$ & $2.24 \mathrm{E}-07$ & $2.22 \mathrm{E}-08$ & $1.6 \%$ & 10.1 & 46 & 9.9 & 42 & 9.0 \\
\hline 241-AY-101 & $2.22 \mathrm{E}-03$ & $1.44 \mathrm{E}-07$ & $1.77 \mathrm{E}-07$ & $1.75 \mathrm{E}-08$ & $1.2 \%$ & 13.2 & 61 & 12.8 & 53 & 6.3 \\
\hline 241-AY-102 & $5.63 \mathrm{E}-03$ & $7.79 \mathrm{E}-08$ & $7.18 \mathrm{E}-08$ & $6.99 \mathrm{E}-09$ & $0.3 \%$ & 35.4 & 200 & 32.7 & 132 & 2.7 \\
\hline 241-AZ-101 & $5.33 \mathrm{E}-03$ & $1.35 \mathrm{E}-07$ & $1.13 \mathrm{E}-07$ & $1.11 \mathrm{E}-08$ & $0.5 \%$ & 21.7 & 105 & 20.7 & 84 & 4.3 \\
\hline 241-AZ-102 & $2.70 \mathrm{E}-03$ & $5.44 \mathrm{E}-07$ & $5.55 \mathrm{E}-07$ & $5.53 \mathrm{E}-08$ & $3.7 \%$ & 3.7 & 17 & 3.6 & 16 & 24.5 \\
\hline 241-SY-101 & $5.69 \mathrm{E}-03$ & $1.10 \mathrm{E}-06$ & $2.12 \mathrm{E}-07$ & $2.10 \mathrm{E}-08$ & $3.6 \%$ & 9.8 & 48 & 9.6 & 43 & 9.3 \\
\hline 241-SY-102 & $9.14 \mathrm{E}-03$ & $9.61 \mathrm{E}-07$ & $1.27 \mathrm{E}-07$ & $1.25 \mathrm{E}-08$ & $1.9 \%$ & 18.0 & 89 & 17.3 & 74 & 5.1 \\
\hline 241-SY-103 & $4.62 \mathrm{E}-03$ & $1.45 \mathrm{E}-06$ & $5.39 \mathrm{E}-07$ & $5.37 \mathrm{E}-08$ & $5.8 \%$ & 3.4 & 17 & 3.4 & 17 & 26.3 \\
\hline
\end{tabular}

Notes:

In this calculation, $30 \%$ of the raw waste concentrations is ammonia, while hydrogen uses data in the targeted SpG.

It covers the off-normal condition when it occurred (i.e., lost vacuum and vent) while the process is running steadily or the process is finished.

$\mathrm{BB}=$ barometric breathing.

$\mathrm{LFL}=$ lower flammability limit. 
Table B-9. Time to Lower Flammability Limit for Evaporator Vessel C-A-1 with $62 \%$ Filled at SpG 1.55, Temperature of $155^{\circ} \mathrm{F}, 30 \% \mathrm{NH}_{3}$.

\begin{tabular}{|c|c|c|c|c|c|c|c|c|c|c|}
\hline Tanks & $\begin{array}{c}\text { Ammonia } \\
\text { transport } \\
\text { constant } \\
\text { k1 } \\
(\mathrm{min}-1)\end{array}$ & $\begin{array}{c}\text { Ammonia } \\
\text { transport } \\
\text { constant } \\
\text { k2 } \\
(\mathrm{M} / \mathrm{min})\end{array}$ & $\begin{array}{c}\mathrm{UH}_{2} \\
\text { hydrogen } \\
\text { unit rate } \\
\text { (mole/m³ } \\
\text { per sec) }\end{array}$ & $\begin{array}{c}\mathrm{UCH}_{4} \\
\text { methane } \\
\text { unit rate } \\
\text { (mole/m } \\
\text { per sec) }\end{array}$ & $\begin{array}{c}\text { Steady- } \\
\text { state } \\
\mathrm{NH}_{3} \\
\mathrm{LFL} \\
(\%)\end{array}$ & $\begin{array}{c}\text { Time } \\
\text { to } \\
\text { reach } \\
25 \% \\
\text { LFL at } \\
\text { BB } \\
\text { vent } \\
\text { (days) }\end{array}$ & $\begin{array}{l}\text { Time to } \\
\text { reach } \\
100 \% \\
\text { LFL at } \\
\text { BB vent } \\
\text { (days) }\end{array}$ & $\begin{array}{c}\text { Time to } \\
\text { reach } \\
25 \% \\
\text { LFL at } \\
\text { zero } \\
\text { vent } \\
\text { (days) }\end{array}$ & $\begin{array}{l}\text { Time to } \\
\text { reach } \\
100 \% \\
\text { LFL at } \\
\text { zero } \\
\text { vent } \\
\text { (days) }\end{array}$ & $\begin{array}{c}\text { Vent } \\
\text { rate } \\
\text { keep } \\
\text { below } \\
25 \% \\
\text { LFL } \\
\text { (cfh) }\end{array}$ \\
\hline 241-AN-101 & $6.18 \mathrm{E}-03$ & $1.70 \mathrm{E}-07$ & $4.67 \mathrm{E}-07$ & $4.65 \mathrm{E}-08$ & $0.5 \%$ & 5.0 & 21 & 4.9 & 20 & 18.0 \\
\hline $241-\mathrm{AN}-102$ & $6.81 \mathrm{E}-03$ & $2.04 \mathrm{E}-07$ & $1.98 \mathrm{E}-06$ & $1.97 \mathrm{E}-07$ & $0.6 \%$ & 1.2 & 5 & 1.2 & 5 & 76.5 \\
\hline $241-\mathrm{AN}-103$ & $4.17 \mathrm{E}-03$ & $3.92 \mathrm{E}-07$ & $2.79 \mathrm{E}-07$ & $2.77 \mathrm{E}-08$ & $1.8 \%$ & 8.0 & 36 & 7.8 & 33 & 11.4 \\
\hline 241-AN-104 & $2.65 \mathrm{E}-03$ & $3.03 \mathrm{E}-07$ & $4.03 \mathrm{E}-07$ & $4.01 \mathrm{E}-08$ & $2.1 \%$ & 5.4 & 24 & 5.3 & 23 & 16.7 \\
\hline 241-AN-105 & $3.17 \mathrm{E}-03$ & $2.52 \mathrm{E}-07$ & $3.32 \mathrm{E}-07$ & $3.30 \mathrm{E}-08$ & $1.5 \%$ & 6.8 & 30 & 6.7 & 28 & 13.4 \\
\hline 241-AN-106 & $5.88 \mathrm{E}-03$ & $2.16 \mathrm{E}-07$ & $6.49 \mathrm{E}-07$ & $6.48 \mathrm{E}-08$ & $0.7 \%$ & 3.5 & 15 & 3.5 & 14 & 25.3 \\
\hline 241-AN-107 & $8.25 \mathrm{E}-03$ & $1.85 \mathrm{E}-07$ & $1.01 \mathrm{E}-06$ & $1.01 \mathrm{E}-07$ & $0.4 \%$ & 2.3 & 9 & 2.3 & 9 & 39.0 \\
\hline 241-AP-101 & $6.95 \mathrm{E}-03$ & $4.23 \mathrm{E}-07$ & $1.85 \mathrm{E}-07$ & $1.83 \mathrm{E}-08$ & $1.1 \%$ & 12.5 & 57 & 12.2 & 50 & 7.3 \\
\hline 241-AP-102 & $5.08 \mathrm{E}-03$ & $4.74 \mathrm{E}-07$ & $3.56 \mathrm{E}-07$ & $3.54 \mathrm{E}-08$ & $1.7 \%$ & 6.2 & 28 & 6.2 & 26 & 14.5 \\
\hline 241-AP-103 & $4.97 \mathrm{E}-03$ & $2.72 \mathrm{E}-07$ & $8.10 \mathrm{E}-07$ & $8.09 \mathrm{E}-08$ & $1.0 \%$ & 2.8 & 12 & 2.8 & 11 & 32.0 \\
\hline 241-AP-104 & $6.48 \mathrm{E}-03$ & $1.32 \mathrm{E}-07$ & $6.13 \mathrm{E}-07$ & $6.11 \mathrm{E}-08$ & $0.4 \%$ & 3.8 & 16 & 3.8 & 15 & 23.5 \\
\hline 241-AP-105 & $2.88 \mathrm{E}-03$ & $3.95 \mathrm{E}-07$ & $2.44 \mathrm{E}-07$ & $2.42 \mathrm{E}-08$ & $2.6 \%$ & 8.8 & 41 & 8.6 & 38 & 10.3 \\
\hline 241-AP-106 & $5.99 \mathrm{E}-03$ & $6.91 \mathrm{E}-08$ & $7.06 \mathrm{E}-07$ & 7.04E-08 & $0.2 \%$ & 3.3 & 14 & 3.3 & 13 & 26.9 \\
\hline 241-AP-107 & $8.07 \mathrm{E}-03$ & $1.02 \mathrm{E}-06$ & $3.21 \mathrm{E}-07$ & $3.19 \mathrm{E}-08$ & $2.4 \%$ & 6.7 & 31 & 6.6 & 29 & 13.4 \\
\hline 241-AP-108 & $7.07 \mathrm{E}-03$ & $9.21 \mathrm{E}-07$ & $3.86 \mathrm{E}-07$ & $3.85 \mathrm{E}-08$ & $2.4 \%$ & 5.6 & 25 & 5.5 & 24 & 16.2 \\
\hline 241-AW-101 & $4.40 \mathrm{E}-03$ & $1.12 \mathrm{E}-08$ & $2.39 \mathrm{E}-07$ & $2.37 \mathrm{E}-08$ & $0.0 \%$ & 10.1 & 43 & 9.8 & 39 & 9.0 \\
\hline $241-\mathrm{AW}-102$ & $8.09 \mathrm{E}-03$ & $6.63 \mathrm{E}-08$ & $3.34 \mathrm{E}-07$ & 3.32E-08 & $0.2 \%$ & 7.1 & 30 & 7.0 & 28 & 12.7 \\
\hline 241-AW-103 & $3.43 \mathrm{E}-03$ & $6.06 \mathrm{E}-07$ & $3.67 \mathrm{E}-07$ & $3.65 \mathrm{E}-08$ & $3.3 \%$ & 5.6 & 26 & 5.6 & 25 & 16.0 \\
\hline 241-AW-104 & $6.10 \mathrm{E}-03$ & $1.72 \mathrm{E}-07$ & $5.49 \mathrm{E}-07$ & $5.47 \mathrm{E}-08$ & $0.5 \%$ & 4.2 & 18 & 4.2 & 17 & 21.2 \\
\hline 241-AW-105 & $1.03 \mathrm{E}-02$ & $7.65 \mathrm{E}-07$ & $7.93 \mathrm{E}-08$ & $7.74 \mathrm{E}-09$ & $1.4 \%$ & 30.0 & 167 & 28.1 & 117 & 3.2 \\
\hline $241-A W-106$ & $5.51 \mathrm{E}-03$ & $3.74 \mathrm{E}-07$ & $2.58 \mathrm{E}-07$ & $2.56 \mathrm{E}-08$ & $1.3 \%$ & 8.8 & 39 & 8.6 & 36 & 10.3 \\
\hline 241-AY-101 & $2.95 \mathrm{E}-03$ & $1.37 \mathrm{E}-07$ & $2.04 \mathrm{E}-07$ & $2.02 \mathrm{E}-08$ & $0.9 \%$ & 11.4 & 51 & 11.1 & 46 & 7.2 \\
\hline $241-\mathrm{AY}-102$ & $5.84 \mathrm{E}-03$ & 7.61E-08 & $8.28 \mathrm{E}-08$ & $8.09 \mathrm{E}-09$ & $0.2 \%$ & 30.1 & 159 & 28.2 & 113 & 3.2 \\
\hline 241-AZ-101 & $6.32 \mathrm{E}-03$ & $1.25 \mathrm{E}-07$ & $1.22 \mathrm{E}-07$ & $1.20 \mathrm{E}-08$ & $0.4 \%$ & 19.8 & 94 & 19.0 & 77 & 4.7 \\
\hline $241-A Z-102$ & $3.50 \mathrm{E}-03$ & 5.17E-07 & $5.87 \mathrm{E}-07$ & $5.85 \mathrm{E}-08$ & $2.8 \%$ & 3.6 & 16 & 3.6 & 16 & 25.0 \\
\hline 241-SY-101 & $6.69 \mathrm{E}-03$ & $1.02 \mathrm{E}-06$ & $2.45 \mathrm{E}-07$ & $2.43 \mathrm{E}-08$ & $2.9 \%$ & 8.7 & 41 & 8.5 & 37 & 10.5 \\
\hline $241-S Y-102$ & $1.00 \mathrm{E}-02$ & $8.86 \mathrm{E}-07$ & $1.46 \mathrm{E}-07$ & $1.44 \mathrm{E}-08$ & $1.6 \%$ & 15.6 & 75 & 15.0 & 63 & 5.9 \\
\hline 241-SY-103 & $5.59 \mathrm{E}-03$ & $1.35 \mathrm{E}-06$ & $6.21 \mathrm{E}-07$ & $6.19 \mathrm{E}-08$ & $4.5 \%$ & 3.1 & 15 & 3.1 & 14 & 28.7 \\
\hline
\end{tabular}

Notes:

In this calculation, $30 \%$ of the raw waste concentrations is ammonia, while hydrogen uses data in the targeted SpG.

It covers the off-normal condition when it occurred (i.e., lost vacuum and vent) while the process is running steadily or the process is finished.

$\mathrm{BB}=$ barometric breathing.

LFL = lower flammability limit. 


\section{RPP-CALC-29700 REV 1}

Table B-10. Time to Lower Flammability Limit for Evaporator Vessel C-A-1 at $62 \%$ Filled at SpG 1.55 , Temperature of $150^{\circ} \mathrm{F}, 30 \% \mathrm{NH}_{3}$.

\begin{tabular}{|c|c|c|c|c|c|c|c|c|c|c|}
\hline Tanks & $\begin{array}{c}\text { Ammonia } \\
\text { transport } \\
\text { constant } \\
\text { k1 } \\
\text { (min-1) }\end{array}$ & $\begin{array}{c}\text { Ammonia } \\
\text { transport } \\
\text { constant } \\
k 2 \\
(M / m i n)\end{array}$ & $\begin{array}{c}\mathrm{UH}_{2} \\
\text { hydrogen } \\
\text { unit rate } \\
\text { (mole/m³ } \\
\text { per sec) }\end{array}$ & $\begin{array}{c}\mathrm{UCH}_{4} \\
\text { methane } \\
\text { unit rate } \\
\text { (mole/m } \\
\text { per sec) }\end{array}$ & $\begin{array}{c}\text { Steady- } \\
\text { state } \\
\mathrm{NH}_{3} \\
\text { LFL } \\
(\%)\end{array}$ & $\begin{array}{l}\text { Time to } \\
\text { reach } \\
25 \% \\
\text { LFL at } \\
\text { BB vent } \\
\text { (days) }\end{array}$ & $\begin{array}{c}\text { Time } \\
\text { to } \\
\text { reach } \\
100 \% \\
\text { LFL at } \\
\text { BB } \\
\text { vent } \\
\text { (days) }\end{array}$ & $\begin{array}{c}\text { Time to } \\
\text { reach } \\
25 \% \\
\text { LFL at } \\
\text { zero } \\
\text { vent } \\
\text { (days) }\end{array}$ & $\begin{array}{l}\text { Time to } \\
\text { reach } \\
100 \% \\
\text { LFL at } \\
\text { zero vent } \\
\text { (days) }\end{array}$ & $\begin{array}{c}\text { Vent } \\
\text { rate } \\
\text { keep } \\
\text { below } \\
25 \% \\
\text { LFL } \\
\text { (cfh) }\end{array}$ \\
\hline 241-AN-101 & $6.11 \mathrm{E}-03$ & $1.71 \mathrm{E}-07$ & $3.64 \mathrm{E}-07$ & $3.61 \mathrm{E}-08$ & $0.5 \%$ & 6.5 & 28 & 6.4 & 26 & 13.9 \\
\hline 241-AN-102 & $6.74 \mathrm{E}-03$ & $2.05 \mathrm{E}-07$ & $1.54 \mathrm{E}-06$ & $1.54 \mathrm{E}-07$ & $0.6 \%$ & 1.5 & 6 & 1.5 & 6 & 59.2 \\
\hline 241-AN-103 & $4.12 \mathrm{E}-03$ & $3.94 \mathrm{E}-07$ & $2.19 \mathrm{E}-07$ & $2.17 \mathrm{E}-08$ & $1.8 \%$ & 10.3 & 47 & 10.1 & 43 & 8.8 \\
\hline 24l-AN-104 & $2.61 \mathrm{E}-03$ & $3.04 \mathrm{E}-07$ & $3.15 \mathrm{E}-07$ & $3.13 \mathrm{E}-08$ & $2.2 \%$ & 7.0 & 32 & 6.9 & 29 & 12.9 \\
\hline 241-AN-105 & $3.12 \mathrm{E}-03$ & $2.53 \mathrm{E}-07$ & $2.59 \mathrm{E}-07$ & $2.56 \mathrm{E}-08$ & $1.5 \%$ & 8.8 & 39 & 8.6 & 36 & 10.3 \\
\hline 241-AN-106 & $5.82 \mathrm{E}-03$ & $2.17 \mathrm{E}-07$ & $5.05 \mathrm{E}-07$ & $5.02 \mathrm{E}-08$ & $0.7 \%$ & 4.6 & 19 & 4.6 & 19 & 19.5 \\
\hline 241-AN-107 & $8.17 \mathrm{E}-03$ & $1.86 \mathrm{E}-07$ & $7.99 \mathrm{E}-07$ & $7.97 \mathrm{E}-08$ & $0.4 \%$ & 2.9 & 12 & 2.9 & 12 & 30.5 \\
\hline 241-AP-101 & $6.87 \mathrm{E}-03$ & $4.25 \mathrm{E}-07$ & $1.45 \mathrm{E}-07$ & $1.42 \mathrm{E}-08$ & $1.1 \%$ & 16.2 & 77 & 15.6 & 65 & 5.7 \\
\hline 241-AP-102 & $5.02 \mathrm{E}-03$ & $4.76 \mathrm{E}-07$ & $2.77 \mathrm{E}-07$ & $2.75 \mathrm{E}-08$ & $1.8 \%$ & 8.1 & 36 & 8.0 & 34 & 11.2 \\
\hline 241-AP-103 & $4.91 \mathrm{E}-03$ & $2.73 \mathrm{E}-07$ & $6.30 \mathrm{E}-07$ & $6.28 \mathrm{E}-08$ & $1.0 \%$ & 3.6 & 15 & 3.6 & 15 & 24.7 \\
\hline 241-AP-104 & $6.41 \mathrm{E}-03$ & $1.33 \mathrm{E}-07$ & 4.77E-07 & $4.74 \mathrm{E}-08$ & $0.4 \%$ & 4.9 & 21 & 4.9 & 20 & 18.2 \\
\hline 241-AP-105 & $2.85 \mathrm{E}-03$ & $3.95 \mathrm{E}-07$ & $1.91 \mathrm{E}-07$ & $1.88 \mathrm{E}-08$ & $2.6 \%$ & 11.5 & 55 & 11.2 & 49 & 8.0 \\
\hline 241-AP-106 & $5.92 \mathrm{E}-03$ & $6.94 \mathrm{E}-08$ & $5.50 \mathrm{E}-07$ & $5.47 \mathrm{E}-08$ & $0.2 \%$ & 4.3 & 18 & 4.3 & 17 & 20.8 \\
\hline 241-AP-107 & $8.00 \mathrm{E}-03$ & $1.02 \mathrm{E}-06$ & $2.51 \mathrm{E}-07$ & $2.48 \mathrm{E}-08$ & $2.4 \%$ & 8.7 & 40 & 8.6 & 37 & 10.4 \\
\hline 241-AP-108 & $6.99 \mathrm{E}-03$ & $9.26 \mathrm{E}-07$ & $3.01 \mathrm{E}-07$ & $2.98 \mathrm{E}-08$ & $2.5 \%$ & 7.2 & 33 & 7.1 & 31 & 12.5 \\
\hline 241-AW-101 & $4.35 \mathrm{E}-03$ & $1.13 \mathrm{E}-08$ & $1.87 \mathrm{E}-07$ & $1.85 \mathrm{E}-08$ & $0.0 \%$ & 13.0 & 58 & 12.7 & 51 & 7.0 \\
\hline 241-AW-102 & $8.01 \mathrm{E}-03$ & $6.67 \mathrm{E}-08$ & $2.60 \mathrm{E}-07$ & $2.58 \mathrm{E}-08$ & $0.2 \%$ & 9.2 & 40 & 9.0 & 36 & 9.8 \\
\hline $241-\mathrm{AW}-103$ & $3.39 \mathrm{E}-03$ & $6.07 \mathrm{E}-07$ & $2.86 \mathrm{E}-07$ & $2.83 \mathrm{E}-08$ & $3.3 \%$ & 7.3 & 35 & 7.2 & 32 & 12.4 \\
\hline 241-AW-104 & $6.03 \mathrm{E}-03$ & $1.73 \mathrm{E}-07$ & $4.28 \mathrm{E}-07$ & $4.25 \mathrm{E}-08$ & $0.5 \%$ & 5.5 & 23 & 5.4 & 22 & 16.4 \\
\hline 241-AW-105 & $1.04 \mathrm{E}-02$ & $7.59 \mathrm{E}-07$ & $6.28 \mathrm{E}-08$ & $6.01 \mathrm{E}-09$ & $1.4 \%$ & 39.1 & 248 & 35.8 & 150 & 2.5 \\
\hline 241-AW-106 & $5.45 \mathrm{E}-03$ & $3.75 \mathrm{E}-07$ & $2.02 \mathrm{E}-07$ & $1.99 \mathrm{E}-08$ & $1.3 \%$ & 11.5 & 52 & 11.2 & 46 & 8.0 \\
\hline 241-AY-101 & $2.91 \mathrm{E}-03$ & $1.37 \mathrm{E}-07$ & $1.59 \mathrm{E}-07$ & $1.57 \mathrm{E}-08$ & $0.9 \%$ & 14.9 & 69 & 14.4 & 59 & 5.6 \\
\hline $241-A Y-102$ & $6.01 \mathrm{E}-03$ & $7.54 \mathrm{E}-08$ & $6.54 \mathrm{E}-08$ & $6.28 \mathrm{E}-09$ & $0.2 \%$ & 39.3 & 235 & 36.0 & 145 & 2.5 \\
\hline 241-AZ-101 & $6.25 \mathrm{E}-03$ & $1.26 \mathrm{E}-07$ & $1.05 \mathrm{E}-07$ & $1.03 \mathrm{E}-08$ & $0.4 \%$ & 23.4 & 115 & 22.2 & 90 & 4.0 \\
\hline $241-\mathrm{AZ}-102$ & $3.45 \mathrm{E}-03$ & $5.18 \mathrm{E}-07$ & $4.93 \mathrm{E}-07$ & 4.91E-08 & $2.8 \%$ & 4.3 & 20 & 4.3 & 19 & 20.8 \\
\hline 241-SY-101 & $6.62 \mathrm{E}-03$ & $1.03 \mathrm{E}-06$ & $1.91 \mathrm{E}-07$ & $1.89 \mathrm{E}-08$ & $2.9 \%$ & 11.3 & 54 & 11.0 & 48 & 8.1 \\
\hline 241-SY-102 & $9.96 \mathrm{E}-03$ & $8.92 \mathrm{E}-07$ & $1.14 \mathrm{E}-07$ & $1.12 \mathrm{E}-08$ & $1.7 \%$ & 20.3 & 102 & 19.4 & 82 & 4.6 \\
\hline 241-SY-103 & $5.53 \mathrm{E}-03$ & $1.36 \mathrm{E}-06$ & $4.84 \mathrm{E}-07$ & $4.81 \mathrm{E}-08$ & $4.6 \%$ & 4.0 & 20 & 4.0 & 19 & 22.2 \\
\hline
\end{tabular}

Notes: SpG.

In this calculation, $30 \%$ of the raw waste concentrations is ammonia, while hydrogen uses data in the targeted

It covers the off-normal condition when it occurred (i.e., lost vacuum and vent) while the process is running steadily or the process is finished.

$\mathrm{BB}=$ barometric breathing.

LFL = lower flammability limit. 


\section{RPP-CALC-29700 REV 1}

Table B-11. Time to Lower Flammability Limit for Evaporator Vessel C-A-1 with $62 \%$ Filled at SpG 1.5, Temperature of $155^{\circ} \mathrm{F}, 30 \% \mathrm{NH}_{3}$.

\begin{tabular}{|c|c|c|c|c|c|c|c|c|c|c|}
\hline Tanks & $\begin{array}{c}\text { Ammonia } \\
\text { transport } \\
\text { constant } \\
\text { k1 } \\
(\mathrm{min}-1)\end{array}$ & $\begin{array}{c}\text { Ammonia } \\
\text { transport } \\
\text { constant } \\
\text { k2 } \\
(\mathrm{M} / \mathrm{min})\end{array}$ & $\begin{array}{c}\mathrm{UH}_{2} \\
\text { hydrogen } \\
\text { unit rate } \\
\text { (mole/m³ } \\
\text { per sec) }\end{array}$ & $\begin{array}{c}\mathrm{UCH}_{4} \\
\text { methane } \\
\text { unit rate } \\
\text { (mole/m³ } \\
\text { per sec) }\end{array}$ & $\begin{array}{c}\text { Steady- } \\
\text { state } \\
\mathrm{NH}_{3} \\
\mathrm{LFL} \\
(\%)\end{array}$ & $\begin{array}{l}\text { Time to } \\
\text { reach } \\
25 \% \\
\text { LFL at } \\
\text { BB vent } \\
\text { (days) }\end{array}$ & $\begin{array}{l}\text { Time to } \\
\text { reach } \\
100 \% \\
\text { LFL at } \\
\text { BB vent } \\
\text { (days) }\end{array}$ & $\begin{array}{l}\text { Time to } \\
\text { reach } \\
\mathbf{2 5 \%} \\
\text { LFL at } \\
\text { zero } \\
\text { vent } \\
\text { (days) }\end{array}$ & $\begin{array}{c}\text { Time to } \\
\text { reach } \\
100 \% \\
\text { LFL at } \\
\text { zero } \\
\text { vent } \\
\text { (days) }\end{array}$ & 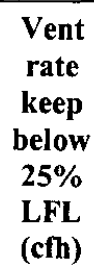 \\
\hline 241-AN-101 & $7.20 \mathrm{E}-03$ & $1.58 \mathrm{E}-07$ & $4.14 \mathrm{E}-07$ & 4.12E-08 & $0.4 \%$ & 5.7 & 24 & 5.6 & 23 & 15.9 \\
\hline 241-AN-102 & $7.83 \mathrm{E}-03$ & $1.89 \mathrm{E}-07$ & $1.75 \mathrm{E}-06$ & $1.75 \mathrm{E}-07$ & $0.5 \%$ & 1.3 & 5 & 1.3 & 5 & 67.3 \\
\hline 241-AN-103 & $5.14 \mathrm{E}-03$ & $3.67 \mathrm{E}-07$ & $2.48 \mathrm{E}-07$ & $2.46 \mathrm{E}-08$ & $1.3 \%$ & 9.2 & 41 & 9.0 & 37 & 9.9 \\
\hline 241-AN-104 & $3.47 \mathrm{E}-03$ & $2.87 \mathrm{E}-07$ & $3.58 \mathrm{E}-07$ & $3.56 \mathrm{E}-08$ & $1.5 \%$ & 6.3 & 28 & 6.2 & 26 & 14.4 \\
\hline 241-AN-105 & $4.05 \mathrm{E}-03$ & $2.38 \mathrm{E}-07$ & $2.95 \mathrm{E}-07$ & $2.93 \mathrm{E}-08$ & $1.1 \%$ & 7.8 & 34 & 7.6 & 32 & 11.7 \\
\hline 241-AN-106 & $6.51 \mathrm{E}-03$ & $2.06 \mathrm{E}-07$ & $5.76 \mathrm{E}-07$ & $5.74 \mathrm{E}-08$ & $0.6 \%$ & 4.0 & 17 & 4.0 & 16 & 22.3 \\
\hline 241-AN-107 & $9.00 \mathrm{E}-03$ & $1.74 \mathrm{E}-07$ & $8.94 \mathrm{E}-07$ & $8.92 \mathrm{E}-08$ & $0.4 \%$ & 2.6 & 11 & 2.6 & 10 & 34.3 \\
\hline 241-AP-101 & $7.96 \mathrm{E}-03$ & $3.91 \mathrm{E}-07$ & $1.64 \mathrm{E}-07$ & $1.62 \mathrm{E}-08$ & $0.9 \%$ & 14.3 & 66 & 13.8 & 57 & 6.4 \\
\hline 241-AP-102 & $6.10 \mathrm{E}-03$ & $4.42 \mathrm{E}-07$ & $3.16 \mathrm{E}-07$ & $3.14 \mathrm{E}-08$ & $1.4 \%$ & 7.2 & 32 & 7.0 & 29 & 12.6 \\
\hline 241-AP-103 & $5.98 \mathrm{E}-03$ & $2.53 \mathrm{E}-07$ & $7.18 \mathrm{E}-07$ & $7.16 \mathrm{E}-08$ & $0.8 \%$ & 3.2 & 13 & 3.2 & 13 & 28.1 \\
\hline 241-AP-104 & $7.43 \mathrm{E}-03$ & $1.23 \mathrm{E}-07$ & $5.43 \mathrm{E}-07$ & $5.41 E-08$ & $0.3 \%$ & 4.3 & 18 & 4.3 & 17 & 20.8 \\
\hline 241-AP-105 & $3.74 \mathrm{E}-03$ & $3.73 \mathrm{E}-07$ & $2.17 \mathrm{E}-07$ & $2.15 \mathrm{E}-08$ & $1.9 \%$ & 10.3 & 47 & 10.0 & 43 & 8.9 \\
\hline 241-AP-106 & $6.81 \mathrm{E}-03$ & $6.49 \mathrm{E}-08$ & $6.26 \mathrm{E}-07$ & $6.24 \mathrm{E}-08$ & $0.2 \%$ & 3.8 & 16 & 3.7 & 15 & 23.8 \\
\hline 241-AP-107 & $8.33 \mathrm{E}-03$ & $9.90 \mathrm{E}-07$ & $2.85 \mathrm{E}-07$ & $2.83 \mathrm{E}-08$ & $2.2 \%$ & 7.6 & 35 & 7.5 & 32 & 11.8 \\
\hline 241-AP-108 & $7.99 \mathrm{E}-03$ & $8.56 \mathrm{E}-07$ & $3.43 \mathrm{E}-07$ & $3.41 \mathrm{E}-08$ & $2.0 \%$ & 6.4 & 29 & 6.3 & 27 & 14.1 \\
\hline 24I-AW-101 & $5.39 \mathrm{E}-03$ & $1.05 \mathrm{E}-08$ & $2.12 \mathrm{E}-07$ & $2.10 \mathrm{E}-08$ & $0.0 \%$ & 11.4 & 49 & 11.1 & 44 & 8.0 \\
\hline 241-AW-102 & $8.43 \mathrm{E}-03$ & $6.41 \mathrm{E}-08$ & $2.97 \mathrm{E}-07$ & $2.95 \mathrm{E}-08$ & $0.1 \%$ & 8.0 & 34 & 7.9 & 32 & 11.3 \\
\hline 241-AW-103 & $4.35 \mathrm{E}-03$ & $5.70 \mathrm{E}-07$ & $3.26 \mathrm{E}-07$ & $3.24 \mathrm{E}-08$ & $2.4 \%$ & 6.6 & 30 & 6.5 & 28 & 13.7 \\
\hline 241-AW-104 & $6.85 \mathrm{E}-03$ & $1.62 \mathrm{E}-07$ & $4.87 \mathrm{E}-07$ & $4.85 \mathrm{E}-08$ & $0.4 \%$ & 4.8 & 20 & 4.7 & 19 & 18.8 \\
\hline $241-\mathrm{AW}-105$ & $1.02 \mathrm{E}-02$ & $7.58 \mathrm{E}-07$ & $7.05 \mathrm{E}-08$ & $6.86 \mathrm{E}-09$ & $1.4 \%$ & 34.0 & 200 & 31.5 & 132 & 2.8 \\
\hline 241-AW-106 & $6.53 \mathrm{E}-03$ & $3.48 \mathrm{E}-07$ & $2.29 \mathrm{E}-07$ & $2.27 \mathrm{E}-08$ & $1.0 \%$ & 10.1 & 45 & 9.9 & 41 & 9.0 \\
\hline 241-AY-101 & $3.81 \mathrm{E}-03$ & $1.30 \mathrm{E}-07$ & $1.81 \mathrm{E}-07$ & $1.79 \mathrm{E}-08$ & $0.6 \%$ & 13.0 & 59 & 12.7 & 52 & 6.3 \\
\hline 241-AY-102 & $6.15 \mathrm{E}-03$ & $7.39 \mathrm{E}-08$ & $7.38 \mathrm{E}-08$ & 7.19E-09 & $0.2 \%$ & 34.1 & 189 & 31.6 & 127 & 2.8 \\
\hline 241-AZ-101 & $6.86 \mathrm{E}-03$ & $1.20 \mathrm{E}-07$ & $1.13 \mathrm{E}-07$ & $1.11 \mathrm{E}-08$ & $0.3 \%$ & 21.6 & 104 & 20.6 & 83 & 4.3 \\
\hline $241-A Z-102$ & $4.42 \mathrm{E}-03$ & $4.86 \mathrm{E}-07$ & $5.15 \mathrm{E}-07$ & $5.13 \mathrm{E}-08$ & $2.1 \%$ & 4.2 & 19 & 4.2 & 18 & 21.2 \\
\hline 241-SY-101 & $7.71 \mathrm{E}-03$ & $9.46 \mathrm{E}-07$ & $2.17 \mathrm{E}-07$ & $2.16 \mathrm{E}-08$ & $2.3 \%$ & 10.0 & 47 & 9.8 & 42 & 9.1 \\
\hline $241-S Y-102$ & $1.01 \mathrm{E}-02$ & $8.70 \mathrm{E}-07$ & $1.30 \mathrm{E}-07$ & $1.28 \mathrm{E}-08$ & $1.6 \%$ & 17.7 & 86 & 17.0 & 71 & 5.2 \\
\hline $241-S Y-103$ & $6.61 \mathrm{E}-03$ & $1.26 \mathrm{E}-06$ & $5.50 \mathrm{E}-07$ & $5.48 \mathrm{E}-08$ & $3.5 \%$ & 3.7 & 17 & 3.7 & 16 & 24.3 \\
\hline
\end{tabular}

Notes:

In this calculation, $20 \%$ of the raw waste concentrations is ammonia, while hydrogen uses data in the targeted SpG.

It covers the off-normal condition when it occurred (i.e., lost vacuum and vent) while the process is running steadily or the process is finished.

$\mathrm{BB}=$ barometric breathing.

$\mathrm{LFL}=$ lower flammability limit. 
Table B-12. Time to Lower Flammability Limit for Evaporator Vessel C-A-1 with $62 \%$ Filled at SpG 1.6, Temperature of $155^{\circ} \mathrm{F}, 30 \% \mathrm{NH}_{3}$.

\begin{tabular}{|c|c|c|c|c|c|c|c|c|c|c|}
\hline Tanks & $\begin{array}{c}\text { Ammonia } \\
\text { transport } \\
\text { constant } \\
\text { k1 } \\
\text { (min-1) }\end{array}$ & $\begin{array}{c}\text { Ammonia } \\
\text { transport } \\
\text { constant } \\
\text { k2 } \\
(\mathrm{M} / \mathrm{min})\end{array}$ & $\begin{array}{c}\mathrm{UH}_{2} \\
\text { hydrogen } \\
\text { unit rate } \\
\text { (mole/m³ } \\
\text { per sec) }\end{array}$ & $\begin{array}{c}\mathrm{UCH}_{4} \\
\text { methane } \\
\text { unit rate } \\
\left(\mathrm{mole} / \mathrm{m}^{3}\right. \\
\text { per sec) }\end{array}$ & $\begin{array}{c}\text { Steady- } \\
\text { state } \\
\mathrm{NH}_{3} \\
\mathrm{LFL} \\
(\%)\end{array}$ & $\begin{array}{l}\text { Time to } \\
\text { reach } \\
25 \% \\
\text { LFL at } \\
\text { BB vent } \\
\text { (days) }\end{array}$ & $\begin{array}{c}\text { Time to } \\
\text { reach } \\
100 \% \\
\text { LFL at } \\
\text { BB vent } \\
\text { (days) }\end{array}$ & $\begin{array}{c}\text { Time to } \\
\text { reach } \\
25 \% \\
\text { LFL at } \\
\text { zero } \\
\text { vent } \\
\text { (days) }\end{array}$ & $\begin{array}{l}\text { Time to } \\
\text { reach } \\
100 \% \\
\text { LFL at } \\
\text { zero vent } \\
\text { (days) }\end{array}$ & 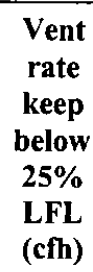 \\
\hline 241-AN-101 & $5.25 \mathrm{E}-03$ & $1.82 \mathrm{E}-07$ & $5.21 \mathrm{E}-07$ & $5.19 \mathrm{E}-08$ & $0.6 \%$ & 4.4 & 19 & 4.4 & 18 & 20.2 \\
\hline 241-AN-102 & $5.88 \mathrm{E}-03$ & $2.19 \mathrm{E}-07$ & $2.21 \mathrm{E}-06$ & $2.21 \mathrm{E}-07$ & $0.7 \%$ & 1.0 & 4 & 1.0 & 4 & 86.0 \\
\hline 241-AN-103 & $3.34 \mathrm{E}-03$ & $4.15 \mathrm{E}-07$ & $3.11 \mathrm{E}-07$ & $3.09 \mathrm{E}-08$ & $2.3 \%$ & 7.0 & 32 & 6.9 & 30 & 13.0 \\
\hline 241-AN-104 & $2.00 \mathrm{E}-03$ & $3.16 \mathrm{E}-07$ & $4.50 \mathrm{E}-07$ & $4.48 \mathrm{E}-08$ & $3.0 \%$ & 4.7 & 21 & 4.6 & 20 & 19.3 \\
\hline 241-AN-105 & $2.44 \mathrm{E}-03$ & $2.64 \mathrm{E}-07$ & $3.70 \mathrm{E}-07$ & $3.68 \mathrm{E}-08$ & $2.0 \%$ & 5.9 & 26 & 5.8 & 25 & 15.2 \\
\hline $241-\mathrm{AN}-106$ & $4.96 \mathrm{E}-03$ & $2.31 \mathrm{E}-07$ & $7.24 \mathrm{E}-07$ & $7.23 \mathrm{E}-08$ & $0.9 \%$ & 3.1 & 13 & 3.1 & 13 & 28.4 \\
\hline 241-AN-107 & $7.34 \mathrm{E}-03$ & $1.99 \mathrm{E}-07$ & $1.14 \mathrm{E}-06$ & $1.13 \mathrm{E}-07$ & $0.5 \%$ & 2.0 & 8 & 2.0 & 8 & 43.8 \\
\hline 241-AP-101 & $6.01 \mathrm{E}-03$ & $4.54 \mathrm{E}-07$ & $2.06 \mathrm{E}-07$ & $2.04 \mathrm{E}-08$ & $1.4 \%$ & 11.1 & 50 & 10.8 & 45 & 8.2 \\
\hline 241-AP-102 & 4.19E-03 & $5.04 \mathrm{E}-07$ & $3.96 \mathrm{E}-07$ & $3.95 \mathrm{E}-08$ & $2.2 \%$ & 5.5 & 24 & 5.4 & 23 & 16.5 \\
\hline 241-AP-103 & $4.08 \mathrm{E}-03$ & $2.89 \mathrm{E}-07$ & $9.04 \mathrm{E}-07$ & $9.02 \mathrm{E}-08$ & $1.3 \%$ & 2.5 & 11 & 2.5 & 10 & 36.1 \\
\hline 241-AP-104 & $5.55 \mathrm{E}-03$ & $1.41 \mathrm{E}-07$ & $6.84 \mathrm{E}-07$ & $6.82 \mathrm{E}-08$ & $0.5 \%$ & 3.4 & 14 & 3.4 & 14 & 26.4 \\
\hline 241-AP-105 & $2.20 \mathrm{E}-03$ & $4.13 \mathrm{E}-07$ & $2.72 \mathrm{E}-07$ & $2.70 \mathrm{E}-08$ & $3.5 \%$ & 7.6 & 36 & 7.4 & 33 & 12.0 \\
\hline 241-AP-106 & $5.06 \mathrm{E}-03$ & $7.38 \mathrm{E}-08$ & $7.88 \mathrm{E}-07$ & $7.86 \mathrm{E}-08$ & $0.3 \%$ & 3.0 & 12 & 2.9 & 12 & 30.1 \\
\hline 241-AP-107 & $7.15 \mathrm{E}-03$ & $1.10 \mathrm{E}-06$ & $3.58 \mathrm{E}-07$ & $3.56 \mathrm{E}-08$ & $2.9 \%$ & 5.9 & 27 & 5.8 & 26 & 15.3 \\
\hline 241-AP-108 & $6.13 \mathrm{E}-03$ & $9.88 \mathrm{E}-07$ & $4.31 \mathrm{E}-07$ & 4.29E- 08 & $3.0 \%$ & 4.9 & 22 & 4.8 & 21 & 18.5 \\
\hline 241-AW-101 & $3.56 \mathrm{E}-03$ & $1.19 \mathrm{E}-08$ & $2.66 \mathrm{E}-07$ & $2.64 \mathrm{E}-08$ & $0.1 \%$ & 9.0 & 38 & 8.8 & 35 & 10.1 \\
\hline 241-AW-102 & $7.17 \mathrm{E}-03$ & $7.13 \mathrm{E}-08$ & $3.72 \mathrm{E}-07$ & $3.71 \mathrm{E}-08$ & $0.2 \%$ & 6.4 & 27 & 6.3 & 25 & 14.2 \\
\hline 241-AW-103 & $2.68 \mathrm{E}-03$ & $6.37 \mathrm{E}-07$ & $4.09 \mathrm{E}-07$ & $4.07 \mathrm{E}-08$ & $4.4 \%$ & 4.8 & 23 & 4.7 & 22 & 18.8 \\
\hline $241-A W-104$ & $5.17 \mathrm{E}-03$ & $1.84 \mathrm{E}-07$ & $6.13 \mathrm{E}-07$ & $6.11 \mathrm{E}-08$ & $0.7 \%$ & 3.8 & 16 & 3.7 & 15 & 23.8 \\
\hline 241-AW-105 & $1.03 \mathrm{E}-02$ & $7.72 \mathrm{E}-07$ & $8.82 \mathrm{E}-08$ & $8.63 \mathrm{E}-09$ & $1.4 \%$ & 26.8 & 143 & 25.2 & 105 & 3.5 \\
\hline 241-AW-106 & $4.60 \mathrm{E}-03$ & $3.98 \mathrm{E}-07$ & $2.88 \mathrm{E}-07$ & $2.86 \mathrm{E}-08$ & $1.6 \%$ & 7.8 & 35 & 7.6 & 32 & 11.6 \\
\hline 241-AY-101 & $2.25 \mathrm{E}-03$ & $1.44 \mathrm{E}-07$ & $2.28 \mathrm{E}-07$ & $2.26 \mathrm{E}-08$ & $1.2 \%$ & 10.1 & 45 & 9.8 & 41 & 8.1 \\
\hline 241-AY-102 & $5.53 \mathrm{E}-03$ & $7.84 \mathrm{E}-08$ & $9.21 \mathrm{E}-08$ & $9.02 \mathrm{E}-09$ & $0.3 \%$ & 26.9 & 137 & 25.3 & 102 & 3.5 \\
\hline 241-AZ-101 & $5.39 \mathrm{E}-03$ & $1.34 \mathrm{E}-07$ & $1.33 \mathrm{E}-07$ & $1.31 \mathrm{E}-08$ & $0.5 \%$ & 18.1 & 85 & 17.4 & 71 & 5.1 \\
\hline $241-A Z-102$ & $2.74 \mathrm{E}-03$ & $5.43 \mathrm{E}-07$ & $6.62 \mathrm{E}-07$ & $6.60 \mathrm{E}-08$ & $3.7 \%$ & 3.0 & 14 & 3.0 & 14 & 29.4 \\
\hline 241-SY-101 & $5.76 \mathrm{E}-03$ & $1.10 \mathrm{E}-06$ & $2.73 \mathrm{E}-07$ & $2.71 \mathrm{E}-08$ & $3.6 \%$ & 7.5 & 36 & 7.4 & 33 & 12.0 \\
\hline $241-S Y-102$ & $9.22 \mathrm{E}-03$ & $9.55 \mathrm{E}-07$ & $1.63 \mathrm{E}-07$ & $1.61 \mathrm{E}-08$ & $1.9 \%$ & 13.8 & 66 & 13.3 & 57 & 6.7 \\
\hline $241-S Y-103$ & $4.68 \mathrm{E}-03$ & $1.44 \mathrm{E}-06$ & $6.92 \mathrm{E}-07$ & $6.90 \mathrm{E}-08$ & $5.8 \%$ & 2.6 & 13 & 2.6 & 13 & 34.0 \\
\hline
\end{tabular}

Notes:

In this calculation, $30 \%$ of the raw waste concentrations is ammonia, while hydrogen uses data in the targeted SpG.

It covers the off-normal condition when it occurred (i.e., lost vacuum and vent) while the process is running steadily or the process is finished.

$\mathrm{BB}=$ barometric breathing.

LFL = lower flammability limit. 
Table B-13. Time to Lower Flammability Limit for Evaporator Vessel C-A-1 with $62 \%$ Filled at SpG 1.7 Temperature of $155^{\circ} \mathrm{F}, 30 \% \mathrm{NH}_{3}$.

\begin{tabular}{|c|c|c|c|c|c|c|c|c|c|c|}
\hline Tanks & $\begin{array}{c}\text { Ammonia } \\
\text { transport } \\
\text { constant } \\
\text { k1 } \\
(\text { min-1) }\end{array}$ & $\begin{array}{c}\text { Ammonia } \\
\text { transport } \\
\text { constant } \\
\mathrm{k} 2 \\
(\mathrm{M} / \mathrm{min})\end{array}$ & $\begin{array}{c}\mathrm{UH}_{2} \\
\text { hydrogen } \\
\text { unit rate } \\
\text { (mole/m³ } \\
\text { per sec) }\end{array}$ & $\begin{array}{c}\mathrm{UCH}_{4} \\
\text { methane } \\
\text { unit rate } \\
\text { (mole/m } \\
\text { per sec) }\end{array}$ & $\begin{array}{c}\text { Steady- } \\
\text { state } \\
\mathrm{NH}_{3} \\
\mathrm{LFL} \\
(\%)\end{array}$ & $\begin{array}{l}\text { Time to } \\
\text { reach } \\
25 \% \\
\text { LFL at } \\
\text { BB vent } \\
\text { (days) }\end{array}$ & $\begin{array}{c}\text { Time to } \\
\text { reach } \\
100 \% \\
\text { LFL at } \\
\text { BB vent } \\
\text { (days) }\end{array}$ & $\begin{array}{c}\text { Time to } \\
\text { reach } \\
25 \% \\
\text { LFL at } \\
\text { zero } \\
\text { vent } \\
\text { (days) }\end{array}$ & $\begin{array}{c}\text { Time to } \\
\text { reach } \\
100 \% \\
\text { LFL at } \\
\text { zero vent } \\
\text { (days) }\end{array}$ & $\begin{array}{c}\text { Vent } \\
\text { rate } \\
\text { keep } \\
\text { below } \\
25 \% \\
\text { LFL } \\
\text { (cfh) }\end{array}$ \\
\hline 24l-AN-101 & $3.69 \mathrm{E}-03$ & $2.03 \mathrm{E}-07$ & $6.31 \mathrm{E}-07$ & $6.29 \mathrm{E}-08$ & $1.0 \%$ & 3.6 & 15 & 3.6 & 15 & 24.9 \\
\hline 241-AN-102 & $4.26 \mathrm{E}-03$ & $2.45 \mathrm{E}-07$ & $2.69 \mathrm{E}-06$ & $2.68 \mathrm{E}-07$ & $1.1 \%$ & 0.8 & 3 & 0.8 & 3 & 106.2 \\
\hline 241-AN-103 & $2.09 \mathrm{E}-03$ & $4.51 \mathrm{E}-07$ & $3.77 \mathrm{E}-07$ & $3.75 \mathrm{E}-08$ & $4.0 \%$ & 5.3 & 25 & 5.2 & 24 & 17.0 \\
\hline 241-AN-104 & $1.11 \mathrm{E}-03$ & $3.37 \mathrm{E}-07$ & $5.45 \mathrm{E}-07$ & $5.43 \mathrm{E}-08$ & $5.6 \%$ & 3.4 & 17 & 3.3 & 16 & 26.6 \\
\hline $241-\mathrm{AN}-105$ & $1.42 \mathrm{E}-03$ & $2.83 \mathrm{E}-07$ & $4.48 \mathrm{E}-07$ & $4.46 \mathrm{E}-08$ & $3.7 \%$ & 4.5 & 21 & 4.5 & 20 & 19.9 \\
\hline $241-\mathrm{AN}-106$ & $3.43 \mathrm{E}-03$ & $2.56 \mathrm{E}-07$ & $8.78 \mathrm{E}-07$ & $8.76 \mathrm{E}-08$ & $1.4 \%$ & 2.5 & 11 & 2.5 & 11 & 35.2 \\
\hline $241-\mathrm{AN}-107$ & $5.67 \mathrm{E}-03$ & $2.26 \mathrm{E}-07$ & $1.39 \mathrm{E}-06$ & $1.38 \mathrm{E}-07$ & $0.7 \%$ & 1.7 & 7 & 1.6 & 7 & 54.1 \\
\hline $241-\mathrm{AP}-101$ & $4.39 \mathrm{E}-03$ & $5.09 \mathrm{E}-07$ & $2.49 \mathrm{E}-07$ & $2.47 \mathrm{E}-08$ & $2.2 \%$ & 8.8 & 41 & 8.6 & 37 & 10.3 \\
\hline $241-\mathrm{AP}-102$ & $2.78 \mathrm{E}-03$ & $5.54 \mathrm{E}-07$ & $4.80 \mathrm{E}-07$ & $4.78 \mathrm{E}-08$ & $3.7 \%$ & 4.2 & 20 & 4.2 & 19 & 21.3 \\
\hline 241-AP-103 & $2.69 \mathrm{E}-03$ & $3.17 \mathrm{E}-07$ & $1.10 \mathrm{E}-06$ & $1.09 \mathrm{E}-07$ & $2.2 \%$ & 2.0 & 9 & 2.0 & 8 & 45.5 \\
\hline 241-AP-104 & $3.96 \mathrm{E}-03$ & $1.58 \mathrm{E}-07$ & $8.28 \mathrm{E}-07$ & 8.27E-08 & $0.7 \%$ & 2.8 & 12 & 2.7 & 11 & 32.3 \\
\hline 241-AP-105 & $1.25 \mathrm{E}-03$ & $4.41 \mathrm{E}-07$ & $3.29 \mathrm{E}-07$ & $3.27 \mathrm{E}-08$ & $6.6 \%$ & 5.3 & 28 & 5.3 & 27 & 16.9 \\
\hline 241-AP-106 & $3.52 \mathrm{E}-03$ & $8.20 \mathrm{E}-08$ & $9.55 \mathrm{E}-07$ & $9.53 \mathrm{E}-08$ & $0.4 \%$ & 2.4 & 10 & 2.4 & 10 & 36.8 \\
\hline $241-\mathrm{AP}-107$ & $5.49 \mathrm{E}-03$ & $1.24 \mathrm{E}-06$ & 4.33E-07 & 4.32E-08 & $4.2 \%$ & 4.6 & 22 & 4.5 & 21 & 19.7 \\
\hline $241-\mathrm{AP}-108$ & $4.50 \mathrm{E}-03$ & $1.11 \mathrm{E}-06$ & $5.22 \mathrm{E}-07$ & $5.20 \mathrm{E}-08$ & $4.6 \%$ & 3.7 & 18 & 3.7 & 17 & 24.2 \\
\hline 241-AW-101 & $2.26 \mathrm{E}-03$ & $1.30 \mathrm{E}-08$ & $3.22 \mathrm{E}-07$ & $3.20 \mathrm{E}-08$ & $0.1 \%$ & 7.4 & 31 & 7.3 & 29 & 12.2 \\
\hline 241-AW-102 & $5.51 \mathrm{E}-03$ & 8.07E-08 & $4.51 \mathrm{E}-07$ & $4.49 \mathrm{E}-08$ & $0.3 \%$ & 5.2 & 22 & 5.2 & 21 & 17.2 \\
\hline 241-AW-103 & $1.59 \mathrm{E}-03$ & $6.86 \mathrm{E}-07$ & $4.96 \mathrm{E}-07$ & 4.94E-08 & $8.0 \%$ & 3.2 & 18 & 3.2 & 17 & 27.7 \\
\hline 241-AW-104 & $3.62 \mathrm{E}-03$ & $2.04 \mathrm{E}-07$ & $7.42 \mathrm{E}-07$ & $7.41 \mathrm{E}-08$ & $1.1 \%$ & 3.0 & 13 & 3.0 & 13 & 29.3 \\
\hline 241-AW-105 & $9.71 \mathrm{E}-03$ & $8.24 \mathrm{E}-07$ & $1.06 \mathrm{E}-07$ & $1.04 \mathrm{E}-08$ & $1.6 \%$ & 21.8 & 111 & 20.7 & 87 & 4.3 \\
\hline 241-AW-106 & $3.12 \mathrm{E}-03$ & $4.40 \mathrm{E}-07$ & $3.48 \mathrm{E}-07$ & $3.46 \mathrm{E}-08$ & $2.6 \%$ & 6.1 & 28 & 6.0 & 26 & 14.7 \\
\hline 241-AY-101 & $1.29 \mathrm{E}-03$ & $1.54 \mathrm{E}-07$ & $2.75 \mathrm{E}-07$ & $2.73 \mathrm{E}-08$ & $2.2 \%$ & 7.9 & 36 & 7.8 & 33 & 10.3 \\
\hline 241-AY-102 & 4.92E-03 & $8.29 \mathrm{E}-08$ & $1.11 \mathrm{E}-07$ & $1.09 \mathrm{E}-08$ & $0.3 \%$ & 22.0 & 106 & 21.0 & 85 & 4.2 \\
\hline $241-\mathrm{AZ}-101$ & $3.82 \mathrm{E}-03$ & $1.49 \mathrm{E}-07$ & $1.54 \mathrm{E}-07$ & $1.52 \mathrm{E}-08$ & $0.7 \%$ & 15.3 & 71 & 14.8 & 61 & 6.0 \\
\hline 241-AZ-102 & $1.64 \mathrm{E}-03$ & $5.85 \mathrm{E}-07$ & $8.20 \mathrm{E}-07$ & $8.18 \mathrm{E}-08$ & $6.7 \%$ & 2.1 & 11 & 2.1 & 11 & 42.3 \\
\hline 241-SY-101 & $4.15 \mathrm{E}-03$ & $1.23 \mathrm{E}-06$ & $3.30 \mathrm{E}-07$ & $3.28 \mathrm{E}-08$ & $5.5 \%$ & 5.6 & 29 & 5.6 & 27 & 16.0 \\
\hline 241-SY-102 & $7.64 \mathrm{E}-03$ & $1.09 \mathrm{E}-06$ & $1.97 \mathrm{E}-07$ & $1.95 \mathrm{E}-08$ & $2.7 \%$ & 11.0 & 52 & 10.7 & 47 & 8.3 \\
\hline $241-S Y-103$ & $3.19 \mathrm{E}-03$ & $1.59 \mathrm{E}-06$ & $8.39 \mathrm{E}-07$ & 8.37E-08 & $9.3 \%$ & 1.8 & 10 & 1.8 & 10 & 50.7 \\
\hline
\end{tabular}

Notes:

In this calculation, $30 \%$ of the raw waste concentrations is ammonia, while hydrogen uses data in the targeted SpG.

It covers the off-normal condition when it occurred (i.e., lost vacuum and vent) while the process is running steadily or the process is finished.

$\mathrm{BB}=$ barometric breathing.

$\mathrm{LFL}=$ lower flammability limit. 
Table B-14. Time to Lower Flammability Limit for Evaporator Vessel C-A-1 with $62 \%$ Filled at SpG 1.6, Temperature of $160^{\circ} \mathrm{F}, 30 \% \mathrm{NH}_{3}$.

\begin{tabular}{|c|c|c|c|c|c|c|c|c|c|c|}
\hline Tanks & $\begin{array}{c}\text { Ammonia } \\
\text { transport } \\
\text { constant } \\
\text { k1 } \\
(\text { min-1) }\end{array}$ & $\begin{array}{c}\text { Ammonia } \\
\text { transport } \\
\text { constant } \\
\text { k2 } \\
(\mathrm{M} / \mathrm{min})\end{array}$ & $\begin{array}{c}\mathrm{UH}_{2} \\
\text { hydrogen } \\
\text { unit rate } \\
\text { (mole/m³ } \\
\text { per sec) }\end{array}$ & $\begin{array}{c}\mathrm{UCH}_{4} \\
\text { methane } \\
\text { unit rate } \\
\text { (mole/m³ } \\
\text { per sec) }\end{array}$ & $\begin{array}{c}\text { Steady- } \\
\text { state } \\
\mathrm{NH}_{3} \\
\text { LFL } \\
(\%)\end{array}$ & $\begin{array}{l}\text { Time to } \\
\text { reach } \\
25 \% \\
\text { LFL at } \\
\text { BB vent } \\
\text { (days) }\end{array}$ & $\begin{array}{l}\text { Time to } \\
\text { reach } \\
100 \% \\
\text { LFL at } \\
\text { BB vent } \\
\text { (days) }\end{array}$ & $\begin{array}{l}\text { Time to } \\
\text { reach } \\
25 \% \\
\text { LFL at } \\
\text { zero } \\
\text { vent } \\
\text { (days) } \\
\end{array}$ & $\begin{array}{c}\text { Time to } \\
\text { reach } \\
100 \% \\
\text { LFL at } \\
\text { zero vent } \\
\text { (days) }\end{array}$ & $\begin{array}{c}\text { Vent } \\
\text { rate } \\
\text { keep } \\
\text { below } \\
25 \% \\
\text { LFL } \\
\text { (cfh) }\end{array}$ \\
\hline 241-AN-101 & $5.07 \mathrm{E}-03$ & $1.84 \mathrm{E}-07$ & $6.67 \mathrm{E}-07$ & $6.65 \mathrm{E}-08$ & $0.7 \%$ & 3.4 & 14 & 3.4 & 14 & 26.2 \\
\hline 241-AN-102 & $5.69 \mathrm{E}-03$ & $2.21 \mathrm{E}-07$ & $2.82 \mathrm{E}-06$ & $2.82 \mathrm{E}-07$ & $0.7 \%$ & 0.8 & 3 & 0.8 & 3 & 110.9 \\
\hline 241-AN-103 & $3.22 \mathrm{E}-03$ & 4.17E-07 & $3.97 \mathrm{E}-07$ & $3.95 \mathrm{E}-08$ & $2.4 \%$ & 5.4 & 24 & 5.3 & 23 & 16.8 \\
\hline 241-AN-104 & $1.92 \mathrm{E}-03$ & $3.18 \mathrm{E}-07$ & $5.75 \mathrm{E}-07$ & $5.74 \mathrm{E}-08$ & $3.1 \%$ & 3.6 & 16 & 3.5 & 16 & 25.1 \\
\hline 241-AN-105 & $2.35 \mathrm{E}-03$ & $2.66 \mathrm{E}-07$ & $4.75 \mathrm{E}-07$ & $4.73 \mathrm{E}-08$ & $2.1 \%$ & 4.5 & 20 & 4.5 & 19 & 19.8 \\
\hline 241-AN-106 & $4.79 \mathrm{E}-03$ & $2.33 \mathrm{E}-07$ & $9.30 \mathrm{E}-07$ & $9.28 \mathrm{E}-08$ & $0.9 \%$ & 2.4 & 10 & 2.4 & 10 & 36.8 \\
\hline 241-AN-107 & $7.12 \mathrm{E}-03$ & $2.02 \mathrm{E}-07$ & $1.44 \mathrm{E}-06$ & $1.44 \mathrm{E}-07$ & $0.5 \%$ & 1.6 & 7 & 1.6 & 6 & 56.0 \\
\hline 241-AP-101 & $5.81 \mathrm{E}-03$ & $4.59 \mathrm{E}-07$ & $2.63 \mathrm{E}-07$ & $2.61 \mathrm{E}-08$ & $1.5 \%$ & 8.5 & 38 & 8.3 & 35 & 10.7 \\
\hline 241-AP-102 & $4.04 \mathrm{E}-03$ & $5.08 \mathrm{E}-07$ & $5.08 \mathrm{E}-07$ & $5.07 \mathrm{E}-08$ & $2.4 \%$ & 4.2 & 19 & 4.2 & 18 & 21.4 \\
\hline 241-AP-103 & $3.94 \mathrm{E}-03$ & $2.91 \mathrm{E}-07$ & $1.16 \mathrm{E}-06$ & $1.16 \mathrm{E}-07$ & $1.4 \%$ & 1.9 & 8 & 1.9 & 8 & 46.9 \\
\hline 241-AP-104 & $5.36 \mathrm{E}-03$ & $1.43 \mathrm{E}-07$ & $8.77 \mathrm{E}-07$ & $8.75 \mathrm{E}-08$ & $0.5 \%$ & 2.6 & 11 & 2.6 & 11 & 34.1 \\
\hline 241-AP-105 & $2.11 \mathrm{E}-03$ & $4.14 \mathrm{E}-07$ & $3.49 \mathrm{E}-07$ & $3.47 \mathrm{E}-08$ & $3.7 \%$ & 5.8 & 27 & 5.7 & 26 & 15.6 \\
\hline 241-AP-106 & $4.89 \mathrm{E}-03$ & $7.45 \mathrm{E}-08$ & $1.01 \mathrm{E}-06$ & $1.01 \mathrm{E}-07$ & $0.3 \%$ & 2.3 & 9 & 2.3 & 9 & 39.0 \\
\hline 241-AP-107 & $6.94 \mathrm{E}-03$ & $1.11 \mathrm{E}-06$ & $4.59 \mathrm{E}-07$ & $4.58 \mathrm{E}-08$ & $3.0 \%$ & 4.5 & 21 & 4.5 & 20 & 19.9 \\
\hline 241-AP-108 & $5.94 \mathrm{E}-03$ & $1.00 \mathrm{E}-06$ & $5.53 \mathrm{E}-07$ & $5.51 \mathrm{E}-08$ & $3.2 \%$ & 3.7 & 17 & 3.7 & 16 & 24.2 \\
\hline 241-AW-101 & $3.43 \mathrm{E}-03$ & $1.20 \mathrm{E}-08$ & $3.40 \mathrm{E}-07$ & $3.38 \mathrm{E}-08$ & $0.1 \%$ & 6.9 & 29 & 6.8 & 27 & 13.0 \\
\hline $241-A W-102$ & $6.96 \mathrm{E}-03$ & $7.23 \mathrm{E}-08$ & $4.78 \mathrm{E}-07$ & $4.76 \mathrm{E}-08$ & $0.2 \%$ & 4.9 & 20 & 4.8 & 19 & 18.4 \\
\hline 241-AW-103 & $2.58 \mathrm{E}-03$ & $6.40 \mathrm{E}-07$ & $5.26 \mathrm{E}-07$ & $5.24 \mathrm{E}-08$ & $4.7 \%$ & 3.6 & 18 & 3.6 & 17 & 24.7 \\
\hline 241-AW-104 & $5.00 \mathrm{E}-03$ & $1.85 \mathrm{E}-07$ & $7.86 \mathrm{E}-07$ & $7.84 \mathrm{E}-08$ & $0.7 \%$ & 2.9 & 12 & 2.9 & 12 & 30.9 \\
\hline 241-AW-105 & $9.96 \mathrm{E}-03$ & $7.92 \mathrm{E}-07$ & $1.13 \mathrm{E}-07$ & $1.11 \mathrm{E}-08$ & $1.5 \%$ & 20.4 & 102 & 19.5 & 82 & 4.6 \\
\hline 241-AW-106 & $4.44 \mathrm{E}-03$ & $4.02 \mathrm{E}-07$ & $3.69 \mathrm{E}-07$ & $3.67 \mathrm{E}-08$ & $1.7 \%$ & 6.0 & 26 & 5.9 & 25 & 15.1 \\
\hline 241-AY-101 & $2.17 \mathrm{E}-03$ & $1.44 \mathrm{E}-07$ & $2.92 \mathrm{E}-07$ & $2.90 \mathrm{E}-08$ & $1.3 \%$ & 7.7 & 34 & 7.6 & 32 & 10.6 \\
\hline $241-\mathrm{AY}-102$ & $5.27 \mathrm{E}-03$ & $7.96 \mathrm{E}-08$ & $1.18 \mathrm{E}-07$ & $1.16 \mathrm{E}-08$ & $0.3 \%$ & 20.5 & 98 & 19.6 & 79 & 4.5 \\
\hline $241-\mathrm{AZ}-101$ & $5.21 \mathrm{E}-03$ & $1.35 \mathrm{E}-07$ & $1.57 \mathrm{E}-07$ & $1.55 \mathrm{E}-08$ & $0.5 \%$ & 15.1 & 69 & 14.6 & 59 & 6.1 \\
\hline 241-AZ-102 & $2.63 \mathrm{E}-03$ & $5.46 \mathrm{E}-07$ & $7.91 \mathrm{E}-07$ & $7.89 \mathrm{E}-08$ & $3.9 \%$ & 2.5 & 12 & 2.5 & 11 & 35.7 \\
\hline 241-SY-101 & $5.57 \mathrm{E}-03$ & $1.11 \mathrm{E}-06$ & $3.50 \mathrm{E}-07$ & $3.48 \mathrm{E}-08$ & $3.7 \%$ & 5.7 & 27 & 5.7 & 26 & 15.7 \\
\hline $241-S Y-102$ & $8.98 \mathrm{E}-03$ & $9.72 \mathrm{E}-07$ & $2.08 \mathrm{E}-07$ & $2.07 \mathrm{E}-08$ & $2.0 \%$ & 10.5 & 49 & 10.3 & 44 & 8.7 \\
\hline 241-SY-103 & $4.51 \mathrm{E}-03$ & $1.45 \mathrm{E}-06$ & $8.87 \mathrm{E}-07$ & $8.85 \mathrm{E}-08$ & $6.1 \%$ & 2.0 & 10 & 2.0 & 10 & 44.7 \\
\hline
\end{tabular}

Notes:

In this calculation, $30 \%$ of the raw waste concentrations is ammonia, while hydrogen uses data in the targeted SpG.

It covers the off-normal condition when it occurred (i.e., lost vacuum and vent) while the process is running steadily or the process is finished.

$\mathrm{BB}=$ barometric breathing.

LFL = lower flammability limit. 
RPP-CALC-29700 REV 1

APPENDIX C

FLAMMABILITY ANALYSIS RESULTS ON CONDENSATE TANK TK-C-100

$\mathrm{C}-\mathrm{i}$ 
RPP-CALC-29700 REV 1

This page intentionally left blank.

C-ii 


\section{APPENDIX C}

\section{FLAMMABILITY ANALYSIS RESULTS ON CONDENSATE TANK TK-C-100}

Table C-1. Input Data of Raw Liquid Waste for Flammability Calculation on Condensate Tank TK-C-100 (2 sheets)

\begin{tabular}{|c|c|c|c|c|c|c|c|c|c|c|c|c|c|}
\hline Tanks & $\begin{array}{c}\text { Total } \\
\text { tank } \\
\text { volume } \\
\left(\mathbf{f t}^{3}\right)\end{array}$ & $\begin{array}{l}\text { Head- } \\
\text { space } \\
\text { temp } \\
\left({ }^{\circ} \mathrm{C}\right)\end{array}$ & $\begin{array}{c}\text { Molar } \\
\text { specific } \\
\text { volume } \\
\text { (L/mole) }\end{array}$ & $\begin{array}{c}\text { Filled } \\
\text { waste } \\
\text { fraction } \\
\mathbf{f}\end{array}$ & $\begin{array}{c}\text { Ratio of } \\
\text { wetted } \\
\text { area and } \\
\text { volume } \\
\left(\mathbf{f t}^{2} / \mathbf{f t}^{3}\right)\end{array}$ & $\begin{array}{c}\text { Ratio of } \\
\text { surface } \\
\text { area and } \\
\text { volume } \\
\left(\mathrm{ft}^{2} / \mathrm{ft}^{3}\right)\end{array}$ & $\begin{array}{c}\text { Ammonia } \\
\text { transport } \\
\text { constant } \\
k_{1}\left(\min ^{-1}\right)\end{array}$ & $\begin{array}{c}\text { Ammonia } \\
\text { transport } \\
\text { constant } \\
\mathrm{k}_{2} \\
(\mathrm{M} / \mathrm{min})\end{array}$ & $\begin{array}{c}\mathrm{U}_{\mathbf{H} 2} \\
\text { unit rate } \\
\text { of } \\
\text { hydrogen } \\
\text { (mole/m } \\
\text { s) }\end{array}$ & $\begin{array}{c}\text { Steady- } \\
\text { state } \\
\mathrm{H}_{2} \\
\text { LFL } \\
(\%)\end{array}$ & $\begin{array}{c}\text { Steady- } \\
\text { state } \\
\text { CH}_{4} \\
\text { LFL } \\
(\%)\end{array}$ & $\begin{array}{c}\text { Steady- } \\
\text { state } \\
\mathrm{NH}_{3} \\
\mathrm{LFL} \\
(\%)\end{array}$ & $\begin{array}{c}\text { Steady- } \\
\text { state } \\
\text { LFL at } \\
\text { BB } \\
(\%)\end{array}$ \\
\hline \multirow{9}{*}{ 05-01 Campaign } & 2,710 & 29 & 24.8 & 0.10 & 1.00 & 0.56 & $7.85 \mathrm{E}-03$ & $1.09 \mathrm{E}-07$ & $4.04 \mathrm{E}-09$ & $1 \%$ & $0 \%$ & $0.2 \%$ & $0.8 \%$ \\
\hline & 2,710 & 29 & 24.8 & 0.20 & 0.64 & 0.28 & $8.83 \mathrm{E}-03$ & $1.22 \mathrm{E}-07$ & $2.60 \mathrm{E}-09$ & $1 \%$ & $0 \%$ & $0.2 \%$ & $1.0 \%$ \\
\hline & 2,710 & 29 & 24.8 & 0.30 & 0.53 & 0.19 & $1.01 \mathrm{E}-02$ & $1.40 \mathrm{E}-07$ & $2.12 \mathrm{E}-09$ & $1 \%$ & $0 \%$ & $0.2 \%$ & $1.3 \%$ \\
\hline & 2,710 & 29 & 24.8 & 0.40 & 0.47 & 0.14 & $1.18 \mathrm{E}-02$ & $1.63 \mathrm{E}-07$ & $1.88 \mathrm{E}-09$ & $1 \%$ & $0 \%$ & $0.2 \%$ & $1.7 \%$ \\
\hline & 2,710 & 29 & 24.8 & 0.50 & 0.43 & 0.11 & $1.41 \mathrm{E}-02$ & $1.96 \mathrm{E}-07$ & $1.73 \mathrm{E}-09$ & $2 \%$ & $0 \%$ & $0.2 \%$ & $2.3 \%$ \\
\hline & 2,710 & 29 & 24.8 & 0.60 & 0.41 & 0.09 & $1.77 \mathrm{E}-02$ & $2.45 \mathrm{E}-07$ & $1.64 \mathrm{E}-09$ & $3 \%$ & $0 \%$ & $0.2 \%$ & $3.2 \%$ \\
\hline & 2,710 & 29 & 24.8 & 0.70 & 0.39 & 0.08 & $2.35 \mathrm{E}-02$ & $3.26 \mathrm{E}-07$ & $1.57 \mathrm{E}-09$ & $4 \%$ & $0 \%$ & $0.2 \%$ & $4.6 \%$ \\
\hline & 2,710 & 29 & 24.8 & 0.80 & 0.38 & 0.07 & $3.53 \mathrm{E}-02$ & $4.89 \mathrm{E}-07$ & $1.52 \mathrm{E}-09$ & $7 \%$ & $0 \%$ & $0.2 \%$ & $7.5 \%$ \\
\hline & 2,710 & 29 & 24.8 & 0.85 & 0.37 & 0.07 & $7.06 \mathrm{E}-02$ & $9.78 \mathrm{E}-07$ & $1.50 \mathrm{E}-09$ & $10 \%$ & $0 \%$ & $0.2 \%$ & $10.3 \%$ \\
\hline \multirow{9}{*}{ 9/3/2003 Sample } & 2,710 & 29 & 24.8 & 0.10 & 1.00 & 0.56 & $7.85 \mathrm{E}-03$ & $2.89 \mathrm{E}-07$ & $4.04 \mathrm{E}-09$ & $1 \%$ & $0 \%$ & $0.6 \%$ & $1.1 \%$ \\
\hline & 2,710 & 29 & 24.8 & 0.20 & 0.64 & 0.28 & $8.83 \mathrm{E}-03$ & $3.25 \mathrm{E}-07$ & $2.60 \mathrm{E}-09$ & $1 \%$ & $0 \%$ & $0.6 \%$ & $1.4 \%$ \\
\hline & 2,710 & 29 & 24.8 & 0.30 & 0.53 & 0.19 & $1.01 \mathrm{E}-02$ & $3.71 \mathrm{E}-07$ & $2.12 \mathrm{E}-09$ & $1 \%$ & $0 \%$ & $0.6 \%$ & $1.7 \%$ \\
\hline & 2,710 & 29 & 24.8 & 0.40 & 0.47 & 0.14 & $1.18 \mathrm{E}-02$ & $4.33 \mathrm{E}-07$ & $1.88 \mathrm{E}-09$ & $1 \%$ & $0 \%$ & $0.6 \%$ & $2.1 \%$ \\
\hline & 2,710 & 29 & 24.8 & 0.50 & 0.43 & 0.11 & $1.41 \mathrm{E}-02$ & $5.20 \mathrm{E}-07$ & $1.73 \mathrm{E}-09$ & $2 \%$ & $0 \%$ & $0.6 \%$ & $2.7 \%$ \\
\hline & 2,710 & 29 & 24.8 & 0.60 & 0.41 & 0.09 & $1.77 \mathrm{E}-02$ & $6.50 \mathrm{E}-07$ & $1.64 \mathrm{E}-09$ & $3 \%$ & $0 \%$ & $0.6 \%$ & $3.5 \%$ \\
\hline & 2,710 & 29 & 24.8 & 0.70 & 0.39 & 0.08 & $2.35 \mathrm{E}-02$ & $8.67 \mathrm{E}-07$ & $1.57 \mathrm{E}-09$ & $4 \%$ & $0 \%$ & $0.6 \%$ & $5.0 \%$ \\
\hline & 2,710 & 29 & 24.8 & 0.80 & 0.38 & 0.07 & $3.53 \mathrm{E}-02$ & $1.30 \mathrm{E}-06$ & $1.52 \mathrm{E}-09$ & $7 \%$ & $0 \%$ & $0.6 \%$ & $7.8 \%$ \\
\hline & 2,710 & 29 & 24.8 & 0.85 & 0.37 & 0.07 & $7.06 \mathrm{E}-02$ & $2.60 \mathrm{E}-06$ & $1.50 \mathrm{E}-09$ & $10 \%$ & $0 \%$ & $0.6 \%$ & $10.7 \%$ \\
\hline
\end{tabular}


Table C-1. Input Data of Raw Liquid Waste for Flammability Calculation on Condensate Tank TK-C-100 (2 sheets)

\begin{tabular}{|c|c|c|c|c|c|c|c|c|c|c|c|c|c|}
\hline Tanks & $\begin{array}{c}\text { Total } \\
\text { tank } \\
\text { volume } \\
\left(\mathbf{f t}^{3}\right)\end{array}$ & $\begin{array}{l}\text { Head- } \\
\text { space } \\
\text { temp } \\
\left({ }^{\circ} \mathrm{C}\right)\end{array}$ & $\begin{array}{c}\text { Molar } \\
\text { specific } \\
\text { volume } \\
\text { (L/mole) }\end{array}$ & $\begin{array}{c}\text { Filled } \\
\text { waste } \\
\text { fraction } \\
\quad \text { f }\end{array}$ & $\begin{array}{l}\text { Ratio of } \\
\text { wetted } \\
\text { area and } \\
\text { volume } \\
\left(\mathrm{ft}^{2} / \mathrm{ft}^{3}\right)\end{array}$ & $\begin{array}{l}\text { Ratio of } \\
\text { surface } \\
\text { area and } \\
\text { volume } \\
\left(\mathrm{ft}^{2} / \mathbf{f t}^{3}\right)\end{array}$ & $\begin{array}{c}\text { Ammonia } \\
\text { transport } \\
\text { constant } \\
k_{1}\left(\min ^{-1}\right)\end{array}$ & $\begin{array}{c}\text { Ammonia } \\
\text { transport } \\
\text { constant } \\
\mathbf{k}_{\mathbf{2}} \\
(\mathrm{M} / \mathrm{min})\end{array}$ & $\begin{array}{c}U_{\mathrm{H} 2} \\
\text { unit rate } \\
\text { of } \\
\text { hydrogen } \\
\text { (mole/m } / \mathrm{m}^{3}- \\
\mathrm{s})\end{array}$ & $\begin{array}{c}\text { Steady- } \\
\text { state } \\
\mathbf{H}_{\mathbf{2}} \\
\text { LFL } \\
(\%)\end{array}$ & $\begin{array}{c}\text { Steady- } \\
\text { state } \\
\text { CH }_{4} \\
\text { LFL } \\
(\%)\end{array}$ & $\begin{array}{c}\text { Steady- } \\
\text { state } \\
\mathrm{NH}_{3} \\
\text { LFL } \\
(\%)\end{array}$ & $\begin{array}{c}\text { Steady- } \\
\text { state } \\
\text { LFL at } \\
\text { BB } \\
(\%)\end{array}$ \\
\hline \multirow{9}{*}{$3 \mathrm{~g} / \mathrm{L} \mathrm{NH} 3$ Case } & 2,710 & 29 & 24.8 & 0.10 & 1.00 & 0.56 & $7.85 \mathrm{E}-03$ & $1.13 \mathrm{E}-06$ & $4.04 \mathrm{E}-09$ & $1 \%$ & $0 \%$ & $2.4 \%$ & $2.9 \%$ \\
\hline & 2,710 & 29 & 24.8 & 0.20 & 0.64 & 0.28 & $8.83 \mathrm{E}-03$ & $1.27 \mathrm{E}-06$ & $2.60 \mathrm{E}-09$ & $1 \%$ & $0 \%$ & $2.4 \%$ & $3.2 \%$ \\
\hline & 2,710 & 29 & 24.8 & 0.30 & 0.53 & 0.19 & $1.01 \mathrm{E}-02$ & $1.45 \mathrm{E}-06$ & $2.12 \mathrm{E}-09$ & $1 \%$ & $0 \%$ & $2.4 \%$ & $3.5 \%$ \\
\hline & 2,710 & 29 & 24.8 & 0.40 & 0.47 & 0.14 & $1.18 \mathrm{E}-02$ & $1.69 \mathrm{E}-06$ & $1.88 \mathrm{E}-09$ & $1 \%$ & $0 \%$ & $2.4 \%$ & $3.9 \%$ \\
\hline & 2,710 & 29 & 24.8 & 0.50 & 0.43 & 0.11 & $1.41 \mathrm{E}-02$ & $2.03 \mathrm{E}-06$ & $1.73 \mathrm{E}-09$ & $2 \%$ & $0 \%$ & $2.4 \%$ & $4.4 \%$ \\
\hline & 2,710 & 29 & 24.8 & 0.60 & 0.41 & 0.09 & $1.77 \mathrm{E}-02$ & $2.54 \mathrm{E}-06$ & $1.64 \mathrm{E}-09$ & $3 \%$ & $0 \%$ & $2.4 \%$ & $5.3 \%$ \\
\hline & 2,710 & 29 & 24.8 & 0.70 & 0.39 & 0.08 & $2.35 \mathrm{E}-02$ & $3.38 \mathrm{E}-06$ & $1.57 \mathrm{E}-09$ & $4 \%$ & $0 \%$ & $2.4 \%$ & $7 \%$ \\
\hline & 2,710 & 29 & 24.8 & 0.80 & 0.38 & 0.07 & $3.53 \mathrm{E}-02$ & $5.07 \mathrm{E}-06$ & $1.52 \mathrm{E}-09$ & $7 \%$ & $0 \%$ & $2.4 \%$ & $10 \%$ \\
\hline & 2,710 & 29 & 24.8 & 0.85 & 0.37 & 0.07 & $7.06 \mathrm{E}-02$ & $1.01 \mathrm{E}-05$ & $1.50 \mathrm{E}-09$ & $10 \%$ & $0 \%$ & $2.4 \%$ & $12 \%$ \\
\hline \multirow{9}{*}{$6.8 \mathrm{~g} / \mathrm{L} \mathrm{NH} 3$ Case } & 2,710 & 29 & 24.8 & 0.10 & 1.00 & 0.56 & $7.85 \mathrm{E}-03$ & $2.55 \mathrm{E}-06$ & 4.04E-09 & $1 \%$ & $0 \%$ & $5.4 \%$ & $5.9 \%$ \\
\hline & 2,710 & 29 & 24.8 & 0.20 & 0.64 & 0.28 & $8.83 \mathrm{E}-03$ & $2.87 \mathrm{E}-06$ & $2.60 \mathrm{E}-09$ & $1 \%$ & $0 \%$ & $5.4 \%$ & $6.2 \%$ \\
\hline & 2,710 & 29 & 24.8 & 0.30 & 0.53 & 0.19 & $1.01 \mathrm{E}-02$ & $3.28 \mathrm{E}-06$ & 2.12E-09 & $1 \%$ & $0 \%$ & $5.4 \%$ & $6.5 \%$ \\
\hline & 2,710 & 29 & 24.8 & 0.40 & 0.47 & 0.14 & $1.18 \mathrm{E}-02$ & $3.83 \mathrm{E}-06$ & $1.88 \mathrm{E}-09$ & $1 \%$ & $0 \%$ & $5.4 \%$ & $6.9 \%$ \\
\hline & 2,710 & 29 & 24.8 & 0.50 & 0.43 & 0.11 & $1.41 \mathrm{E}-02$ & $4.60 \mathrm{E}-06$ & $1.73 \mathrm{E}-09$ & $2 \%$ & $0 \%$ & $5.4 \%$ & $7.5 \%$ \\
\hline & 2,710 & 29 & 24.8 & 0.60 & 0.41 & 0.09 & $1.77 \mathrm{E}-02$ & $5.75 \mathrm{E}-06$ & $1.64 \mathrm{E}-09$ & $3 \%$ & $0 \%$ & $5.4 \%$ & $8.3 \%$ \\
\hline & 2,710 & 29 & 24.8 & 0.70 & 0.39 & 0.08 & $2.35 \mathrm{E}-02$ & $7.66 \mathrm{E}-06$ & $1.57 \mathrm{E}-09$ & $4 \%$ & $0 \%$ & $5.4 \%$ & $10 \%$ \\
\hline & 2,710 & 29 & 24.8 & 0.80 & 0.38 & 0.07 & $3.53 \mathrm{E}-02$ & $1.15 \mathrm{E}-05$ & $1.52 \mathrm{E}-09$ & $7 \%$ & $0 \%$ & $5.4 \%$ & $13 \%$ \\
\hline & 2,710 & 29 & 24.8 & 0.85 & 0.37 & 0.07 & $7.06 \mathrm{E}-02$ & $2.30 \mathrm{E}-05$ & $1.50 \mathrm{E}-09$ & $10 \%$ & $0 \%$ & $5.4 \%$ & $15 \%$ \\
\hline
\end{tabular}

$\mathrm{BB}=$ barometric breathing

LFL = lower flammability limit. 
Table C-2. Results of Flammability Calculation on Condensate Tank TK-C-100.

\begin{tabular}{|c|c|c|c|c|c|c|c|}
\hline Tanks & $\begin{array}{c}\text { Filled } \\
\text { waste } \\
\text { fraction } \\
\text { f }\end{array}$ & $\begin{array}{l}\text { Time to } \\
\text { reach } \\
25 \% \text { LFL at } \\
\text { BB vent } \\
\text { (days) }\end{array}$ & $\begin{array}{l}\text { Time to } \\
\text { reach } \\
100 \% \text { LFL } \\
\text { at BB vent } \\
\text { (days) }\end{array}$ & $\begin{array}{c}\text { Time to } \\
\text { reach } \\
25 \% \text { LFL } \\
\text { at zero } \\
\text { vent (days) }\end{array}$ & $\begin{array}{c}\text { Time to } \\
\text { reach } \\
100 \% \text { LFL } \\
\text { at zero } \\
\text { vent (days) }\end{array}$ & $\begin{array}{c}\text { Vent rate } \\
\text { keep below } \\
25 \% \text { LFL } \\
\text { (cfm) }\end{array}$ & $\begin{array}{c}\text { Vent rate } \\
\text { keep below } \\
100 \% \text { LFL } \\
\text { (cfm) }\end{array}$ \\
\hline \multirow{9}{*}{ 05-01 Campaign } & 0.10 & not occur & not occur & 2,000 & 2,000 & less than $b b$ & less than bb \\
\hline & 0.20 & not occur & not occur & 2,000 & 2,000 & less than bb & less than bb \\
\hline & 0.30 & not occur & not occur & 2,000 & 2,000 & less than bb & less than $b b$ \\
\hline & 0.40 & not occur & not occur & 2,000 & 2,000 & less than bb & less than bb \\
\hline & 0.50 & not occur & not occur & 2,000 & 2,000 & less than bb & less than bb \\
\hline & 0.60 & not occur & not occur & 1,899 & 2,000 & less than bb & less than $\mathrm{bb}$ \\
\hline & 0.70 & not occur & not occur & 1,270 & 2,000 & less than bb & less than bb \\
\hline & 0.80 & not occur & not occur & 764 & 2,000 & less than $b b$ & less than $b b$ \\
\hline & 0.85 & not occur & not occur & 547 & 2,000 & less than $b b$ & less than bb \\
\hline \multirow{9}{*}{ 9/3/2003 Sample } & 0.10 & not occur & not occur & 2,000 & 2,000 & less than $b b$ & less than bb \\
\hline & 0.20 & not occur & not occur & 2,000 & 2,000 & less than bb & less than bb \\
\hline & 0.30 & not occur & not occur & 2,000 & 2,000 & less than $b b$ & less than bb \\
\hline & 0.40 & not occur & not occur & 2,000 & 2,000 & less than $b b$ & less than bb \\
\hline & 0.50 & not occur & not occur & 2,000 & 2,000 & less than bb & less than bb \\
\hline & 0.60 & not occur & not occur & 1,870 & 2,000 & less than $b b$ & less than bb \\
\hline & 0.70 & not occur & not occur & 1,251 & 2,000 & less than $b b$ & less than bb \\
\hline & 0.80 & not occur & not occur & 752 & 2,000 & less than bb & less than bb \\
\hline & 0.85 & not occur & not occur & 538 & 2,000 & less than $b b$ & less than bb \\
\hline \multirow{9}{*}{$3 \mathrm{~g} / \mathrm{L} \mathrm{NH} 3$ Case } & 0.10 & not occur & not occur & 2,000 & 2,000 & less than bb & less than bb \\
\hline & 0.20 & not occur & not occur & 2,000 & 2,000 & less than $b b$ & less than bb \\
\hline & 0.30 & not occur & not occur & 2,000 & 2,000 & less than $\mathrm{bb}$ & less than bb \\
\hline & 0.40 & not occur & not occur & 2,000 & 2,000 & less than $\mathrm{bb}$ & less than bb \\
\hline & 0.50 & not occur & not occur & 2,000 & 2,000 & less than $b b$ & less than $b b$ \\
\hline & 0.60 & not occur & not occur & 1,733 & 2,000 & less than bb & less than bb \\
\hline & 0.70 & not occur & not occur & 1,160 & 2,000 & less than bb & less than bb \\
\hline & 0.80 & not occur & not occur & 698 & 2,000 & less than bb & less than bb \\
\hline & 0.85 & not occur & not occur & 499 & 2,000 & less than bb & less than bb \\
\hline \multirow{9}{*}{$6.8 \mathrm{~g} / \mathrm{L} \mathrm{NH} 3$ Case } & 0.10 & not occur & not occur & 2,000 & 2,000 & less than bb & less than bb \\
\hline & 0.20 & not occur & not occur & 2,000 & 2,000 & less than bb & less than bb \\
\hline & 0.30 & not occur & not occur & 2,000 & 2,000 & less than $b b$ & less than bb \\
\hline & 0.40 & not occur & not occur & 2,000 & 2,000 & less than $b b$ & less than bb \\
\hline & 0.50 & not occur & not occur & 2,000 & 2,000 & less than $b b$ & less than bb \\
\hline & 0.60 & not occur & not occur & 1,501 & 2,000 & less than bb & less than bb \\
\hline & 0.70 & not occur & not occur & 1,004 & 2,000 & less than $b b$ & less than bb \\
\hline & 0.80 & not occur & not occur & 605 & 2,000 & less than bb & less than bb \\
\hline & 0.85 & not occur & not occur & 432 & 2,000 & less than bb & less than bb \\
\hline
\end{tabular}

Notes:

$\mathrm{BB}$ or $\mathrm{bb}=$ barometric breathing.

LFL $\quad=$ lower flammability limit. 
RPP-CALC-29700 REV 1

This page intentionally left blank. 
RPP-CALC-29700 REV 1

\section{APPENDIX D}

FLAMMABILITY ANALYSIS FOR 242-A EVAPORATOR CAMPAIGNS 07-01 AND 07-02

D-i 
RPP-CALC-29700 REV 1

This page intentionally left blank.

D-ii 


\section{APPENDIX D \\ FLAMMABILITY ANALYSIS FOR 242-A EVAPORATOR \\ CAMPAIGNS 07-01 AND 07-02}

This appendix documents the flammability analysis performed as part of the planning for 242-A Evaporator campaigns 07-01 and 07-02 (RPP-PLAN-33127, Process Control Plan for 242-A Evaporator Campaigns 07-01 and 07-02). The analysis was performed to meet the requirements of 242-A Evaporator Technical Safety Requirement (TSR) administrative control (AC) 5.6.1.9 (HNF-15279).

The methodology used in this analysis is taken from RPP-5926, Steady-State Flammable Gas Release Rate Calculation and Lower Flammability Level Evaluation for Hanford Tank Waste, and RPP-8050, Lower Flammability Limit Calculations for Catch Tanks, IMUSTs, DST Annuli, Pit Structures, and Double-Contained Receiver Tanks in Tank Farms at the Hanford Site, and summarized in Chapter 6.0 of this document. The waste feed for Evaporator Campaigns 07-01 and 07-02 is described in RPP-PLAN-33127. The feed compositions are given in SVF-1315, Generate supporting calculations for the "Process Control Plan for 242-A Evaporator Campaigns 07-01 and 07-02" (RPP-PLAN-33127). Table D-1 and Table D-2 list the required input data for the waste feeds (taken from SVF-1315). Validated Microsoft Excel ${ }^{3}$ spreadsheets used for the calculation are listed in Chapter 7.0.

During the campaigns, the evaporator will take feed blended from waste in tanks 241-AP-104 and 241-AW-102. The blending process is to concentrate the $241-\mathrm{AW}-102$ waste from its SpG of 1.07 to 1.28 , which is the SpG of 241-AP-104 waste, before receiving 241-AP-104 waste for better mixing. This modeling effort calculates the flammability at different mixing percentages for 241-AP-104 up to 50\%. Based on Equation 4-2 in the main text, the concentration ratio from $\mathrm{SpG}$ of 1.07 to 1.28 is 4 , i.e., the concentration at $\mathrm{SpG}$ of 1.28 would be four times as concentrated as it is at 1.07 . The input data for the gas generation calculations on various combinations of the blended wastes from 241-AP-104 (raw SpG of 1.28) and 241-AW-102 (concentrated waste at $\mathrm{SpG}$ of 1.28) are given in Table D-3. The raw waste of 241-AP-104 (at SpG of 1.28) and 241-AW-102 (at SpG of 1.07) are also included in Table D-3 for the flammability analysis as comparison. The flammability sensitivity analysis at various $\mathrm{SpG}$ and waste temperatures for different combinations of the waste feeds are performed and given in Tables D-4 through D-6. Table D-4 lists the input data and Tables D-5 and D-6 list the values of the derived terms and the results of the flammability analyses. In general, lower SpG and lower waste temperature result in increased time to $25 \%$ of the LFL.

\footnotetext{
${ }^{3}$ Microsoft Excel is a trademark of Microsoft Corporation, Redmond, Washington.
} 


\section{RPP-CALC-29700 REV 1}

\section{References}

RPP-5926, 2006, Steady-State Flammable Gas Release Rate Calculation and Lower Flammability Level Evaluation for Hanford Tank Waste, Rev. 6, CH2M HILL Hanford Group, Inc., Richland, Washington.

RPP-8050, 2005, Lower Flammability Limit Calculations for Catch Tanks, IMUSTs, DST Annuli, Pit Structures, and Double-Contained Receiver Tanks in Tank Farms at the Hanford Site, Rev. 4-A, CH2M HILL Hanford Group, Inc., Richland, Washington.

HNF-15279, 2006, Technical Safety Requirements for the 242-A Evaporator, Rev. 0-E, CH2M HILL Hanford Group, Inc., Richland, Washington.

RPP-PLAN-33127, 2007, Process Control Plan for 242-A Evaporator Campaigns 07-01 and 07-02, Rev. 0A, CH2M HILL Hanford Group, Inc., Richland, Washington.

SVF-1315, 2007, Generate supporting calculations for the "Process Control Plan for 242-A Evaporator Campaigns 07-01 and 07-02" (RPP-PLAN-33127), CH2M HILL Hanford Group, Inc., Richland, Washington. 
Table D-1. Chemical Composition of Liquid Feeds from Double-Shell Tanks 241-AP-104 and 241-AW-102.

\begin{tabular}{|c|c|c|c|c|c|c|c|c|c|c|c|c|c|c|c|c|}
\hline Constituent & $\underset{(\mu \mathrm{g} / \mathrm{mL})}{\mathrm{Na}}$ & $\underset{(\mu \mathrm{g} / \mathbf{m L})}{\mathbf{A l}}$ & $\underset{(\mu \mathrm{g} / \mathrm{mL})}{\mathbf{F e}}$ & $\underset{(\mu \mathrm{g} / \mathrm{mL})}{\mathrm{Cr}}$ & $\underset{(\mu \mathrm{g} / \mathrm{mL})}{\mathrm{Ni}}$ & $\underset{(\mu \mathrm{g} / \mathrm{mL})}{\mathrm{K}}$ & $\underset{(\mu \mathrm{g} / \mathrm{mL})}{\text { TOC }}$ & $\underset{(\mu \mathrm{g} / \mathrm{mL})}{\mathrm{OH}}$ & $\begin{array}{c}\mathrm{NO}_{2} \\
(\mu \mathrm{g} / \mathrm{mL})\end{array}$ & $\begin{array}{c}\mathrm{NO}_{3} \\
(\mu \mathrm{g} / \mathrm{mL})\end{array}$ & $\underset{(\mu \mathrm{g} / \mathrm{mL})}{\mathrm{CO}_{3}}$ & $\underset{(\mu \mathrm{g} / \mathrm{mL})}{\mathbf{P O}_{4}}$ & $\underset{(\mu \mathrm{g} / \mathrm{mL})}{\mathrm{SO}_{4}}$ & $\underset{(\mu \mathrm{g} / \mathbf{m L})}{\mathbf{F}}$ & $\underset{(\mu \mathrm{g} / \mathrm{mL})}{\mathrm{Cl}}$ & $\underset{(\mu \mathrm{g} / \mathbf{m L})}{\mathrm{NH}_{3}}$ \\
\hline 241-AP-104 & $1.28 \mathrm{E}+05$ & $1.67 \mathrm{E}+04$ & $5.02 \mathrm{E}+00$ & $4.99 \mathrm{E}+02$ & $4.59 \mathrm{E}+01$ & $2.10 \mathrm{E}+03$ & $4.14 \mathrm{E}+03$ & $1.96 \mathrm{E}+04$ & $6.37 E+04$ & $1.00 \mathrm{E}+05$ & $1.73 E+04$ & $3.76 \mathrm{E}+03$ & $2.12 \mathrm{E}+03$ & $3.06 \mathrm{E}+02$ & $5.19 \mathrm{E}+03$ & $1.00 \mathrm{E}+03$ \\
\hline $241-\mathrm{AW}-102$ & $3.76 \mathrm{E}+04$ & $1.94 \mathrm{E}+03$ & $2.00 \mathrm{E}+00$ & $4.02 \mathrm{E}+01$ & $8.31 \mathrm{E}+00$ & $7.43 E+02$ & $1.90 \mathrm{E}+03$ & $2.92 \mathrm{E}+03$ & $1.51 \mathrm{E}+04$ & $1.60 \mathrm{E}+04$ & $1.65 \mathrm{E}+04$ & $2.53 \mathrm{E}+03$ & $1.04 \mathrm{E}+03$ & $2.88 \mathrm{E}+02$ & $5.92 \mathrm{E}+02$ & $5.63 \mathrm{E}+01$ \\
\hline
\end{tabular}

Note: 1 . The feed data are taken from SVF-1315

2. TIC (total inorganic carbon) data was used to derive $\mathrm{CO}_{3}:\left(\mathrm{TIC} \times 5=\mathrm{CO}_{3}\right)$

Table D-2. Radionuclide Composition and SpG of Liquid Feeds.

$\stackrel{\varpi}{\omega}$

\begin{tabular}{|c|c|c|c|c|c|c|c|}
\hline Radionuclide & $\begin{array}{c}\text { Sr-89/90 } \\
(\mu \mathrm{Ci} / \mathrm{g})\end{array}$ & $\begin{array}{c}\mathrm{Am-241} \\
(\mu \mathrm{Ci} / \mathrm{g})\end{array}$ & $\begin{array}{c}\mathbf{P u}-239 \\
(\mu \mathrm{Ci} / \mathrm{g})\end{array}$ & $\begin{array}{c}\mathbf{P u}-240 \\
(\mu \mathrm{Ci} / \mathrm{g})\end{array}$ & $\begin{array}{c}\text { Pu-238 } \\
(\mu \mathrm{Ci} / \mathrm{g})\end{array}$ & $\begin{array}{c}\mathbf{C s}-137 \\
(\mu \mathrm{Ci} / \mathrm{g})\end{array}$ & $\begin{array}{c}\text { SpG } \\
(\mathrm{g} / \mathrm{mL})\end{array}$ \\
\hline $241-\mathrm{AP}-104$ & $1.32 \mathrm{E}+00$ & $1.80 \mathrm{E}-02$ & $1.36 \mathrm{E}-03$ & $1.36 \mathrm{E}-03$ & $1.04 \mathrm{E}-03$ & $1.46 \mathrm{E}+02$ & $1.28 \mathrm{E}+00$ \\
\hline $241-\mathrm{AW}-102$ & $7.86 \mathrm{E}-02$ & $1.72 \mathrm{E}-05$ & $1.53 \mathrm{E}-03$ & $1.53 \mathrm{E}-03$ & $2.42 \mathrm{E}-04$ & $2.71 \mathrm{E}+01$ & $1.07 \mathrm{E}+00$ \\
\hline
\end{tabular}

2. Pu-239/240 was used for Pu-239 and for Pu-240 
Table D-3. Chemical Composition and Radionuclide of Liquid Feeds from Double-Shell Tanks 241-AP-104 and 241-AW-102.

\begin{tabular}{|c|c|c|c|c|c|c|c|c|c|c|c|c|c|}
\hline $\begin{array}{c}\text { Composition of } \\
\text { Mixture Waste of } \\
\text { 241-AP-104 and } \\
\text { 241-AW-102 }\end{array}$ & $\begin{array}{c}\text { Na } \\
\text { in Liquid } \\
{\left[\begin{array}{c}\text { Na] } \\
(\mu \mathrm{g} / \mathrm{mL})\end{array}\right.}\end{array}$ & $\begin{array}{c}\text { Al } \\
\text { in Liquid } \\
{[\mathrm{AI}]} \\
(\mu \mathrm{g} / \mathrm{mL})\end{array}$ & $\begin{array}{c}\mathrm{Fe}^{+3} \\
\text { in Liquid } \\
(\mu \mathrm{g} / \mathrm{mL})\end{array}$ & $\begin{array}{c}\mathrm{Cr}^{+3} \\
\text { in Liquid } \\
(\mu \mathrm{g} / \mathrm{mL})\end{array}$ & $\begin{array}{c}\mathrm{Ni}^{+2} \\
\text { in Liquid } \\
(\mu \mathrm{g} / \mathrm{mL})\end{array}$ & $\begin{array}{c}\mathrm{K}^{+1} \\
\text { in Liquid } \\
(\mu \mathrm{g} / \mathrm{mL})\end{array}$ & $\begin{array}{c}\text { TOC } \\
\text { in Liquid } \\
\text { [TOC] } \\
(\mu \mathrm{g} / \mathrm{mL})\end{array}$ & $\begin{array}{c}\mathrm{OH}^{-1} \\
\text { in Liquid } \\
{[\mathrm{OH}]} \\
(\mu \mathrm{g} / \mathrm{mL})\end{array}$ & $\begin{array}{c}\mathrm{NO}_{2} \\
\text { in Liquid } \\
{\left[\mathrm{NO}_{2}\right]} \\
(\mu \mathrm{g} / \mathrm{mL})\end{array}$ & $\begin{array}{c}\mathrm{NO}_{3} \\
\text { in Liquid } \\
{\left[\mathrm{NO}_{3}\right]} \\
(\mu \mathrm{g} / \mathrm{mL})\end{array}$ & $\begin{array}{c}\mathrm{CO}_{3}^{-2} \\
\text { in Liquid } \\
(\mu \mathrm{g} / \mathrm{mL})\end{array}$ & $\begin{array}{c}\mathrm{PO}_{4}^{-3} \\
\text { in Liquid } \\
(\mu \mathrm{g} / \mathrm{mL})\end{array}$ & $\begin{array}{c}\mathrm{SO}_{4}^{-2} \\
\text { in Liquid } \\
(\mu \mathrm{g} / \mathrm{mL})\end{array}$ \\
\hline Raw 241-AP-104 & $1.28 \mathrm{E}+05$ & $1.67 \mathrm{E}+04$ & $5.02 \mathrm{E}+00$ & $4.99 \mathrm{E}+02$ & $4.59 \mathrm{E}+01$ & $2.10 \mathrm{E}+03$ & $4.14 \mathrm{E}+03$ & $1.96 \mathrm{E}+04$ & $6.37 \mathrm{E}+04$ & $1.00 \mathrm{E}+05$ & $1.73 \mathrm{E}+04$ & $3.76 \mathrm{E}+03$ & $2.12 \mathrm{E}+03$ \\
\hline $2 \mathrm{AW}-0.25 / 4 \mathrm{AP}-0.75$ & $1.33 E+05$ & $1.45 E+04$ & $5.72 \mathrm{E}+00$ & $4.14 \mathrm{E}+02$ & $4.26 \mathrm{E}+01$ & $2.30 \mathrm{E}+03$ & $4.96 \mathrm{E}+03$ & $1.75 \mathrm{E}+04$ & $6.26 \mathrm{E}+04$ & $9.09 \mathrm{E}+04$ & $2.90 \mathrm{E}+04$ & $5.30 \mathrm{E}+03$ & $2.61 E+03$ \\
\hline $2 \mathrm{AW}-0.45 / 4 \mathrm{AP}-0.55$ & $1.37 \mathrm{E}+05$ & $1.26 \mathrm{E}+04$ & $6.28 \mathrm{E}+00$ & $3.45 \mathrm{E}+02$ & $3.99 \mathrm{E}+01$ & $2.46 \mathrm{E}+03$ & $5.62 \mathrm{E}+03$ & $1.59 \mathrm{E}+04$ & $6.17 \mathrm{E}+04$ & $8.34 \mathrm{E}+04$ & $3.85 \mathrm{E}+04$ & $6.53 E+03$ & $3.00 \mathrm{E}+03$ \\
\hline $2 \mathrm{AW}-0.5 / 4 \mathrm{AP}-0.5$ & $1.38 E+05$ & $1.22 \mathrm{E}+04$ & $6.42 \mathrm{E}+00$ & $3.28 \mathrm{E}+02$ & $3.92 \mathrm{E}+01$ & $2.50 \mathrm{E}+03$ & $5.79 \mathrm{E}+03$ & $1.55 \mathrm{E}+04$ & $6.15 E+04$ & $8.15 E+04$ & $4.08 \mathrm{E}+04$ & $6.83 E+03$ & $3.10 \mathrm{E}+03$ \\
\hline $2 \mathrm{AW}-1.0 / 4 \mathrm{AP}-0.0$ & $1.47 E+05$ & $7.60 \mathrm{E}+03$ & $7.83 E+00$ & $1.57 \mathrm{E}+02$ & $3.25 \mathrm{E}+01$ & $2.91 E+03$ & $7.44 \mathrm{E}+03$ & $1.14 \mathrm{E}+04$ & $5.92 E+04$ & $6.27 \mathrm{E}+04$ & $6.44 E+04$ & $9.91 E+03$ & $4.07 \mathrm{E}+03$ \\
\hline Raw $241-A W-102$ & $3.76 \mathrm{E}+04$ & $1.94 \mathrm{E}+03$ & $2.00 \mathrm{E}+00$ & $4.02 \mathrm{E}+01$ & $8.31 \mathrm{E}+00$ & $7.43 E+02$ & $1.90 \mathrm{E}+03$ & $2.92 \mathrm{E}+03$ & $1.51 \mathrm{E}+04$ & $1.60 \mathrm{E}+04$ & $1.65 E+04$ & $2.53 E+03$ & $1.04 \mathrm{E}+03$ \\
\hline $\begin{array}{l}\text { Composition of } \\
\text { Mixture Waste of } \\
\text { 241-AP-104 and } \\
241-\mathrm{AW}-102\end{array}$ & $\underset{\substack{\text { in Liquid }^{-1} \\
(\mu \mathrm{g} / \mathrm{mL})}}{ }$ & $\begin{array}{c}\mathrm{Cl}^{-1} \\
\text { in Liquid } \\
(\mu \mathrm{g} / \mathrm{mL})\end{array}$ & $\begin{array}{c}{ }^{90} \mathrm{Sr} \\
\text { in Waste } \\
{[\mathrm{Sr}]} \\
(\mu \mathrm{Ci} / \mathrm{g})\end{array}$ & $\begin{array}{c}{ }^{241} \mathrm{Am} \\
\text { in Waste } \\
{[\mathrm{Am241]}} \\
(\mu \mathrm{Ci} / \mathrm{g})\end{array}$ & $\begin{array}{c}{ }^{240} \mathrm{Pu} \\
\text { in Waste } \\
{[\mathrm{Pu} 240]} \\
(\mu \mathrm{Ci} / \mathrm{g})\end{array}$ & $\begin{array}{c}{ }^{239} \mathrm{Pu} \\
\text { in Waste } \\
{\left[\begin{array}{l}\mathrm{Pu} 240] \\
(\mu \mathrm{Ci} / \mathrm{g})\end{array}\right.}\end{array}$ & $\begin{array}{c}{ }^{238} \mathrm{Pu} \\
\text { in Waste } \\
{\left[\begin{array}{l}\text { Pu238] } \\
(\mu \mathrm{Ci} / \mathrm{g})\end{array}\right.}\end{array}$ & $\begin{array}{c}{ }^{137} \mathrm{Cs} \\
\text { in Waste } \\
{[\mathrm{Cs}]} \\
(\mu \mathrm{Ci} / \mathrm{g})\end{array}$ & $\begin{array}{c}\text { Liquid } \\
\mathbf{N H}_{3} \\
(\mu \mathrm{g} / \mathrm{mL})\end{array}$ & $\begin{array}{c}\text { Bulk } \\
\text { Density } \\
\text { D } \\
(\mathrm{g} / \mathrm{mL})\end{array}$ & $\begin{array}{c}\text { Liquid } \\
\text { Density DL } \\
(\mathrm{g} / \mathrm{ml})\end{array}$ & $\begin{array}{l}\text { Bulk } \\
\text { Water } \\
{\left[\mathrm{H}_{2} \mathrm{O}\right]} \\
(\mathbf{w t} \%)\end{array}$ & $\begin{array}{l}\text { Liquid } \\
\text { Water } \\
{\left[\mathrm{H}_{2} \mathrm{O}\right]} \\
(\mathbf{w t} \%)\end{array}$ \\
\hline Raw 241-AP-104 & $3.06 \mathrm{E}+02$ & $5.19 \mathrm{E}+03$ & $1.32 \mathrm{E}+00$ & $1.80 \mathrm{E}-02$ & $1.36 \mathrm{E}-03$ & $1.36 \mathrm{E}-03$ & $1.04 \mathrm{E}-03$ & $1.46 \mathrm{E}+02$ & $1.00 \mathrm{E}+03$ & 1.28 & 1.28 & $66 \%$ & $66 \%$ \\
\hline $2 \mathrm{AW}-0.25 / 4 \mathrm{AP}-0.75$ & $5.11 \mathrm{E}+02$ & $4.47 \mathrm{E}+03$ & $1.05 \mathrm{E}+00$ & $1.35 \mathrm{E}-02$ & $2.26 \mathrm{E}-03$ & $2.26 \mathrm{E}-03$ & $9.81 \mathrm{E}-04$ & $1.32 \mathrm{E}+02$ & $7.55 \mathrm{E}+02$ & 1.28 & 1.28 & $65 \%$ & $65 \%$ \\
\hline $2 \mathrm{AW}-0.45 / 4 \mathrm{AP}-0.55$ & $6.75 \mathrm{E}+02$ & $3.90 \mathrm{E}+03$ & $8.40 \mathrm{E}-01$ & $9.93 \mathrm{E}-03$ & $2.99 \mathrm{E}-03$ & $2.99 \mathrm{E}-03$ & $9.31 \mathrm{E}-04$ & $1.20 \mathrm{E}+02$ & $5.58 \mathrm{E}+02$ & 1.28 & 1.28 & $64 \%$ & $64 \%$ \\
\hline $2 \mathrm{AW}-0.5 / 4 \mathrm{AP}-0.5$ & $7.16 \mathrm{E}+02$ & $3.75 E+03$ & $7.87 \mathrm{E}-01$ & $9.03 \mathrm{E}-03$ & $3.17 \mathrm{E}-03$ & $3.17 \mathrm{E}-03$ & $9.18 \mathrm{E}-04$ & $1.17 \mathrm{E}+02$ & $5.09 \mathrm{E}+02$ & 1.28 & 1.28 & $63 \%$ & $63 \%$ \\
\hline $2 \mathrm{AW}-1.0 / 4 \mathrm{AP}-0.0$ & $1.13 \mathrm{E}+03$ & $2.32 \mathrm{E}+03$ & $2.57 \mathrm{E}-01$ & $5.61 \mathrm{E}-05$ & $4.99 \mathrm{E}-03$ & $4.99 \mathrm{E}-03$ & $7.92 \mathrm{E}-04$ & $8.85 \mathrm{E}+01$ & $1.69 \mathrm{E}+01$ & 1.28 & 1.28 & $61 \%$ & $61 \%$ \\
\hline Raw 241-AW-102 & $2.88 \mathrm{E}+02$ & $5.92 \mathrm{E}+02$ & $7.86 \mathrm{E}-02$ & $1.72 \mathrm{E}-05$ & $1.53 \mathrm{E}-03$ & $1.53 \mathrm{E}-03$ & $2.42 \mathrm{E}-04$ & $2.71 E+01$ & $5.63 \mathrm{E}+01$ & 1.07 & 1.07 & $88 \%$ & $88 \%$ \\
\hline
\end{tabular}

Note: The 241-AW-102 waste in the mixture waste has been concentrated from the SpG of 1.07 to 1.28 to match the SpG of $241-\mathrm{AP}-104$ for better mixing. 
Table D-4. Input Data of Liquid Feeds from Double-Shell Tanks 241-AP-104 and 241-AW-102. (2 sheets)

\begin{tabular}{|c|c|c|c|c|c|c|c|c|c|c|c|c|c|}
\hline \multicolumn{2}{|c|}{$\begin{array}{l}\text { Mixed Waste Case at Various } \\
\text { SpG and Waste Temperature }\end{array}$} & \multirow{2}{*}{$\begin{array}{c}\begin{array}{c}\text { Total } \\
\text { Tank } \\
\text { Volume } \\
\left(\mathbf{f t}^{3}\right)\end{array} \\
5611\end{array}$} & \multirow{2}{*}{$\begin{array}{c}\begin{array}{c}\text { Head } \\
\text { space } \\
\text { Temp } \\
\text { ('C) }\end{array} \\
71 \\
\end{array}$} & \multirow{2}{*}{$\begin{array}{c}\begin{array}{c}\text { Molar } \\
\text { Specific } \\
\text { Volume } \\
\text { (L/mole) }\end{array} \\
28.2\end{array}$} & \multirow{2}{*}{$\begin{array}{c}\begin{array}{c}\text { Filled } \\
\text { waste } \\
\text { fraction } \mathbf{f}\end{array} \\
0.62\end{array}$} & \multirow{2}{*}{$\begin{array}{c}\begin{array}{c}\text { Ratio of } \\
\text { Wetted } \\
\text { Area and } \\
\text { Volume } \\
\left(\mathbf{f t}^{2} / \mathbf{f t}^{\mathbf{3}}\right)\end{array} \\
0.53\end{array}$} & \multirow{2}{*}{ 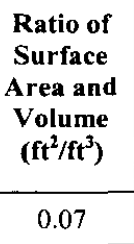 } & \multirow{2}{*}{$\begin{array}{c}\begin{array}{c}\text { RCrad } \\
\left(\mathrm{mole}^{3} \mathbf{m}^{3}-\mathbf{s}\right) \\
\mathbf{H}_{2} \text { from } \\
\text { Radiolysis }\end{array} \\
3.12 \mathrm{E}-08\end{array}$} & \multirow{2}{*}{ 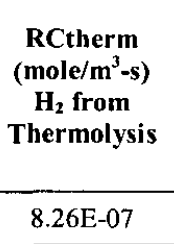 } & \multirow{2}{*}{$\begin{array}{c}\begin{array}{c}\mathbf{N}_{2} \mathbf{O} \\
\text { Release } \\
\text { Rate } \\
\mathbf{R r}\left(\mathbf{N}_{2} \mathbf{O}\right) \\
(\mathbf{c f m})\end{array} \\
1.43 \mathrm{E}-04\end{array}$} & \multirow{2}{*}{$\begin{array}{c}\begin{array}{c}\text { Ammonia } \\
\text { Liquid } \\
\text { Concen. } \\
\text { (mole/L) } / \text { ) }\end{array} \\
1.76 \mathrm{E}-02\end{array}$} & \multirow{2}{*}{$\begin{array}{c}\begin{array}{c}\text { Liquid } \\
\text { Henry } \\
\text { Constant } \\
\text { KH } \\
\text { (M/atm) }\end{array} \\
3.32\end{array}$} & \multirow{2}{*}{$\begin{array}{c}\begin{array}{c}\text { Ammonia } \\
\text { Transport } \\
\text { Coefficient } h \\
(\mathbf{m} / \mathbf{s e c})\end{array} \\
4.25 \mathrm{E}-06\end{array}$} \\
\hline & Raw 241-AP-104 & & & & & & & & & & & & \\
\hline \multirow{5}{*}{$\begin{array}{c}\text { SpG } 1.6 \\
\text { and } \\
160^{\circ} \mathrm{F}\end{array}$} & $2 \mathrm{AW}-0.25 / 4 \mathrm{AP}-0.75$ & 5611 & 71 & 28.2 & 0.62 & 0.53 & 0.07 & $3.29 \mathrm{E}-08$ & $9.34 \mathrm{E}-07$ & $5.53 \mathrm{E}-04$ & $1.33 \mathrm{E}-02$ & 2.98 & 4.37E-06 \\
\hline & $2 \mathrm{AW}-0.45 / 4 \mathrm{AP}-0.55$ & 5611 & 71 & 28.2 & 0.62 & 0.53 & 0.07 & $3.34 \mathrm{E}-08$ & $1.00 \mathrm{E}-06$ & $5.81 \mathrm{E}-03$ & $9.83 \mathrm{E}-03$ & 2.73 & $4.45 \mathrm{E}-06$ \\
\hline & $2 \mathrm{AW}-0.5 / 4 \mathrm{AP}-0.5$ & 5611 & 71 & 28.2 & 0.62 & 0.53 & 0.07 & $3.35 \mathrm{E}-08$ & $1.02 \mathrm{E}-06$ & $4.55 \mathrm{E}-03$ & $8.97 \mathrm{E}-03$ & 2.68 & 4.47E-06 \\
\hline & $2 \mathrm{AW}-1.0 / 4 \mathrm{AP}-0.0$ & 5611 & 71 & 28.2 & 0.62 & 0.53 & 0.07 & $3.16 \mathrm{E}-08$ & $1.08 \mathrm{E}-06$ & $1.30 \mathrm{E}-03$ & $2.98 \mathrm{E}-04$ & 2.16 & 4.67E-06 \\
\hline & Raw 241-AW-102 & 5611 & 71 & 28.2 & 0.62 & 0.53 & 0.07 & $3.16 \mathrm{E}-08$ & $1.08 \mathrm{E}-06$ & $4.76 \mathrm{E}-04$ & $9.92 \mathrm{E}-04$ & 2.16 & $4.67 \mathrm{E}-06$ \\
\hline \multirow{6}{*}{$\begin{array}{c}\text { SpG } 1.7 \\
\text { and } \\
155^{\circ} \mathrm{F}\end{array}$} & Raw 241-AP-104 & 5611 & 68 & 28.0 & 0.62 & 0.53 & 0.07 & $3.42 \mathrm{E}-08$ & $7.75 \mathrm{E}-07$ & $1.43 \mathrm{E}-04$ & $1.76 \mathrm{E}-02$ & 2.26 & $4.71 \mathrm{E}-06$ \\
\hline & $2 \mathrm{AW}-0.25 / 4 \mathrm{AP}-0.75$ & 5611 & 68 & 28.0 & 0.62 & 0.53 & 0.07 & $3.62 \mathrm{E}-08$ & $8.77 \mathrm{E}-07$ & $5.53 \mathrm{E}-04$ & $1.33 \mathrm{E}-02$ & 1.99 & $4.82 \mathrm{E}-06$ \\
\hline & $2 \mathrm{AW}-0.45 / 4 \mathrm{AP}-0.55$ & 5611 & 68 & 28.0 & 0.62 & 0.53 & 0.07 & $3.69 \mathrm{E}-08$ & $9.41 \mathrm{E}-07$ & $5.81 \mathrm{E}-03$ & $9.83 \mathrm{E}-03$ & 1.80 & $4.90 \mathrm{E}-06$ \\
\hline & $2 \mathrm{AW}-0.5 / 4 \mathrm{AP}-0.5$ & 5611 & 68 & 28.0 & 0.62 & 0.53 & 0.07 & $3.69 \mathrm{E}-08$ & $9.55 \mathrm{E}-07$ & $4.55 \mathrm{E}-03$ & $8.97 \mathrm{E}-03$ & 1.76 & 4.92E-06 \\
\hline & $2 \mathrm{AW}-1.0 / 4 \mathrm{AP}-0.0$ & 5611 & 68 & 28.0 & 0.62 & 0.53 & 0.07 & $3.49 \mathrm{E}-08$ & $1.02 \mathrm{E}-06$ & $1.30 \mathrm{E}-03$ & $2.98 \mathrm{E}-04$ & 1.37 & $5.09 \mathrm{E}-06$ \\
\hline & Raw 241-AW-102 & 5611 & 68 & 28.0 & 0.62 & 0.53 & 0.07 & $3.49 \mathrm{E}-08$ & $1.02 \mathrm{E}-06$ & $4.76 \mathrm{E}-04$ & $9.92 \mathrm{E}-04$ & 1.37 & $5.09 \mathrm{E}-06$ \\
\hline \multirow{6}{*}{$\begin{array}{l}\text { SpG } 1.6 \\
\text { and } \\
155^{\circ} \mathrm{F}\end{array}$} & Raw 241-AP-104 & 5611 & 68 & 28.0 & 0.62 & 0.53 & 0.07 & $2.76 \mathrm{E}-08$ & $6.40 \mathrm{E}-07$ & $1.43 \mathrm{E}-04$ & $1.76 \mathrm{E}-02$ & 3.50 & $4.21 \mathrm{E}-06$ \\
\hline & $2 \mathrm{AW}-0.25 / 4 \mathrm{AP}-0.75$ & 5611 & 68 & 28.0 & 0.62 & 0.53 & 0.07 & $2.89 \mathrm{E}-08$ & $7.24 \mathrm{E}-07$ & $5.53 \mathrm{E}-04$ & $1.33 \mathrm{E}-02$ & 3.14 & $4.32 \mathrm{E}-06$ \\
\hline & $2 \mathrm{AW}-0.45 / 4 \mathrm{AP}-0.55$ & 5611 & 68 & 28.0 & 0.62 & 0.53 & 0.07 & $2.94 \mathrm{E}-08$ & $7.77 \mathrm{E}-07$ & $5.81 \mathrm{E}-03$ & $9.83 \mathrm{E}-03$ & 2.88 & $4.41 E-06$ \\
\hline & $2 \mathrm{AW}-0.5 / 4 \mathrm{AP}-0.5$ & 5611 & 68 & 28.0 & 0.62 & 0.53 & 0.07 & $2.94 \mathrm{E}-08$ & $7.88 \mathrm{E}-07$ & $4.55 \mathrm{E}-03$ & $8.97 \mathrm{E}-03$ & 2.82 & $4.43 \mathrm{E}-06$ \\
\hline & $2 \mathrm{AW}-1.0 / 4 \mathrm{AP}-0.0$ & 5611 & 68 & 28.0 & 0.62 & 0.53 & 0.07 & $2.76 \mathrm{E}-08$ & $8.39 \mathrm{E}-07$ & $1.30 \mathrm{E}-03$ & $2.98 \mathrm{E}-04$ & 2.27 & 4.63E-06 \\
\hline & Raw 241-AW-102 & 5611 & 68 & 28.0 & 0.62 & 0.53 & 0.07 & $2.76 \mathrm{E}-08$ & $8.39 \mathrm{E}-07$ & $4.76 \mathrm{E}-04$ & $9.92 \mathrm{E}-04$ & 2.27 & $4.63 \mathrm{E}-06$ \\
\hline \multirow{6}{*}{$\begin{array}{c}\text { SpG } 1.6 \\
\text { and } \\
150^{\circ} \mathrm{F}\end{array}$} & Raw 241-AP-104 & 5611 & 66 & 27.8 & 0.62 & 0.53 & 0.07 & $2.44 \mathrm{E}-08$ & $4.94 \mathrm{E}-07$ & $1.43 \mathrm{E}-04$ & $1.76 \mathrm{E}-02$ & 3.48 & $4.22 \mathrm{E}-06$ \\
\hline & $2 \mathrm{AW}-0.25 / 4 \mathrm{AP}-0.75$ & 5611 & 66 & 27.8 & 0.62 & 0.53 & 0.07 & $2.55 \mathrm{E}-08$ & $5.59 \mathrm{E}-07$ & $5.53 \mathrm{E}-04$ & $1.33 \mathrm{E}-02$ & 3.12 & $4.34 \mathrm{E}-06$ \\
\hline & $2 \mathrm{AW}-0.45 / 4 \mathrm{AP}-0.55$ & 5611 & 66 & 27.8 & 0.62 & 0.53 & 0.07 & $2.58 \mathrm{E}-08$ & $6.00 \mathrm{E}-07$ & $5.81 \mathrm{E}-03$ & $9.83 \mathrm{E}-03$ & 2.86 & $4.42 \mathrm{E}-06$ \\
\hline & $2 \mathrm{AW}-0.5 / 4 \mathrm{AP}-0.5$ & 5611 & 66 & 27.8 & 0.62 & 0.53 & 0.07 & $2.58 \mathrm{E}-08$ & $6.08 \mathrm{E}-07$ & $4.55 \mathrm{E}-03$ & $8.97 \mathrm{E}-03$ & 2.80 & 4.45E-06 \\
\hline & $2 \mathrm{AW}-1.0 / 4 \mathrm{AP}-0.0$ & 5611 & 66 & 27.8 & 0.62 & 0.53 & 0.07 & $2.42 \mathrm{E}-08$ & $6.48 \mathrm{E}-07$ & $1.30 \mathrm{E}-03$ & $2.98 \mathrm{E}-04$ & 2.26 & $4.64 \mathrm{E}-06$ \\
\hline & Raw 241-AW-102 & 5611 & 66 & 27.8 & 0.62 & 0.53 & 0.07 & $2.42 \mathrm{E}-08$ & $6.48 \mathrm{E}-07$ & $4.76 \mathrm{E}-04$ & $9.92 \mathrm{E}-04$ & 2.26 & $4.64 \mathrm{E}-06$ \\
\hline
\end{tabular}


Table D-4. Input Data of Liquid Feeds from Double-Shell Tanks 241-AP-104 and 241-AW-102. (2 sheets)

\begin{tabular}{|c|c|c|c|c|c|c|c|c|c|c|c|c|c|}
\hline \multicolumn{2}{|c|}{$\begin{array}{l}\text { Mixed Waste Case at Various } \\
\text { SpG and Waste Temperature }\end{array}$} & \multirow{2}{*}{$\begin{array}{c}\begin{array}{c}\text { Total } \\
\text { Tank } \\
\text { Volume } \\
\left(\mathrm{ft}^{3}\right)\end{array} \\
5611\end{array}$} & \multirow{2}{*}{$\begin{array}{c}\text { Head } \\
\text { space } \\
\text { Temp } \\
\left({ }^{\circ} \mathrm{C}\right) \\
68\end{array}$} & \multirow{2}{*}{$\begin{array}{c}\begin{array}{c}\text { Molar } \\
\text { Specific } \\
\text { Volume } \\
\text { (L/mole) }\end{array} \\
28.0\end{array}$} & \multirow{2}{*}{$\begin{array}{c}\begin{array}{c}\text { Filled } \\
\text { waste } \\
\text { fraction } \mathbf{f}\end{array} \\
0.62\end{array}$} & \multirow{2}{*}{$\begin{array}{c}\begin{array}{c}\text { Ratio of } \\
\text { Wetted }\end{array} \\
\begin{array}{c}\text { Area and } \\
\text { Volume } \\
\left(\mathbf{f t}^{2} / \mathbf{f t}^{3}\right)\end{array} \\
0.53\end{array}$} & \multirow{2}{*}{$\begin{array}{c}\begin{array}{c}\text { Ratio of } \\
\text { Surface }\end{array} \\
\text { Area and } \\
\begin{array}{c}\text { Volume } \\
\left(\mathbf{f t}^{2} / \mathbf{f t}^{\mathbf{3}}\right)\end{array} \\
0.07\end{array}$} & \multirow{2}{*}{$\begin{array}{c}\begin{array}{c}\text { RCrad } \\
\left(\mathbf{m o l e} / \mathbf{m}^{3}-\mathrm{s}\right) \\
\mathbf{H}_{2} \text { from } \\
\text { Radiolysis }\end{array} \\
2.45 \mathrm{E}-08\end{array}$} & \multirow{2}{*}{$\begin{array}{c}\begin{array}{c}\text { RCtherm } \\
\left.\text { (mole/m } \mathbf{m}^{3}-\mathbf{s}\right) \\
\mathbf{H}_{2} \text { from } \\
\text { Thermolysis }\end{array} \\
5.74 \mathrm{E}-07\end{array}$} & \multirow{2}{*}{$\begin{array}{c}\begin{array}{c}\mathbf{N}_{\mathbf{2}} \mathbf{O} \\
\text { Release } \\
\text { Rate } \\
\mathbf{R r}\left(\mathbf{N}_{\mathbf{2}} \mathbf{O}\right) \\
(\mathbf{c f m})\end{array} \\
1.43 \mathrm{E}-04\end{array}$} & \multirow{2}{*}{$\begin{array}{c}\begin{array}{c}\text { Ammonia } \\
\text { Liquid } \\
\text { Concen. } \\
\text { (mole/L)* }\end{array} \\
1.76 \mathrm{E}-02\end{array}$} & \multirow{2}{*}{$\begin{array}{c}\begin{array}{c}\text { Liquid } \\
\text { Henry } \\
\text { Constant } \\
\text { KH } \\
\text { (M/atm) }\end{array} \\
4.35\end{array}$} & \multirow{2}{*}{$\begin{array}{c}\begin{array}{c}\text { Ammonia } \\
\text { Transport } \\
\text { Coefficient } h \\
\text { (m/sec) }\end{array} \\
3.93 \mathrm{E}-06\end{array}$} \\
\hline & Raw 241-AP-104 & & & & & & & & & & & & \\
\hline \multirow{5}{*}{$\begin{array}{l}\mathrm{SpG} \\
1.55 \text { and } \\
155^{\circ} \mathrm{F}\end{array}$} & $2 \mathrm{AW}-0.25 / 4 \mathrm{AP}-0.75$ & 5611 & 68 & 28.0 & 0.62 & 0.53 & 0.07 & $2.56 \mathrm{E}-08$ & $6.49 \mathrm{E}-07$ & $5.53 \mathrm{E}-04$ & $1.33 \mathrm{E}-02$ & 3.94 & $4.04 \mathrm{E}-06$ \\
\hline & $2 \mathrm{AW}-0.45 / 4 \mathrm{AP}-0.55$ & 5611 & 68 & 28.0 & 0.62 & 0.53 & 0.07 & $2.59 \mathrm{E}-08$ & $6.97 \mathrm{E}-07$ & $5.81 \mathrm{E}-03$ & $9.83 \mathrm{E}-03$ & 3.64 & 4.13E-06 \\
\hline & $2 \mathrm{AW}-0.5 / 4 \mathrm{AP}-0.5$ & 5611 & 68 & 28.0 & 0.62 & 0.53 & 0.07 & $2.59 \mathrm{E}-08$ & 7.07E-07 & $4.55 \mathrm{E}-03$ & $8.97 \mathrm{E}-03$ & 3.57 & $4.15 \mathrm{E}-06$ \\
\hline & $2 \mathrm{AW}-1.0 / 4 \mathrm{AP}-0.0$ & 5611 & 68 & 28.0 & 0.62 & 0.53 & 0.07 & $2.42 \mathrm{E}-08$ & $7.53 \mathrm{E}-07$ & $1.30 \mathrm{E}-03$ & $2.98 \mathrm{E}-04$ & 2.93 & $4.36 \mathrm{E}-06$ \\
\hline & Raw 241-AW-102 & 5611 & 68 & 28.0 & 0.62 & 0.53 & 0.07 & $2.42 \mathrm{E}-08$ & $7.53 \mathrm{E}-07$ & $4.76 \mathrm{E}-04$ & $9.92 \mathrm{E}-04$ & 2.93 & $4.36 \mathrm{E}-06$ \\
\hline \multirow{6}{*}{$\begin{array}{l}\mathrm{SpG} \\
1.55 \text { and } \\
150^{\circ} \mathrm{F}\end{array}$} & Raw 241-AP-104 & 5611 & 66 & 27.8 & 0.62 & 0.53 & 0.07 & $2.17 \mathrm{E}-08$ & $4.43 \mathrm{E}-07$ & $1.43 \mathrm{E}-04$ & $1.76 \mathrm{E}-02$ & 4.32 & $3.95 \mathrm{E}-06$ \\
\hline & $2 \mathrm{AW}-0.25 / 4 \mathrm{AP}-0.75$ & 5611 & 66 & 27.8 & 0.62 & 0.53 & 0.07 & $2.26 \mathrm{E}-08$ & $5.01 \mathrm{E}-07$ & $5.53 \mathrm{E}-04$ & $1.33 \mathrm{E}-02$ & 3.92 & $4.06 \mathrm{E}-06$ \\
\hline & $2 \mathrm{AW}-0.45 / 4 \mathrm{AP}-0.55$ & 5611 & 66 & 27.8 & 0.62 & 0.53 & 0.07 & $2.28 \mathrm{E}-08$ & $5.38 \mathrm{E}-07$ & $5.81 \mathrm{E}-03$ & $9.83 \mathrm{E}-03$ & 3.62 & $4.15 \mathrm{E}-06$ \\
\hline & $2 \mathrm{AW}-0.5 / 4 \mathrm{AP}-0.5$ & 5611 & 66 & 27.8 & 0.62 & 0.53 & 0.07 & $2.28 \mathrm{E}-08$ & $5.45 \mathrm{E}-07$ & $4.55 \mathrm{E}-03$ & $8.97 \mathrm{E}-03$ & 3.55 & $4.17 \mathrm{E}-06$ \\
\hline & $2 \mathrm{AW}-1.0 / 4 \mathrm{AP}-0.0$ & 5611 & 66 & 27.8 & 0.62 & 0.53 & 0.07 & $2.12 \mathrm{E}-08$ & $5.81 \mathrm{E}-07$ & $1.30 \mathrm{E}-03$ & $2.98 \mathrm{E}-04$ & 2.91 & $4.37 \mathrm{E}-06$ \\
\hline & Raw 241-AW-102 & 5611 & 66 & 27.8 & 0.62 & 0.53 & 0.07 & $2.12 \mathrm{E}-08$ & $5.81 \mathrm{E}-07$ & 4.76E-04 & $9.92 \mathrm{E}-04$ & 2.91 & $4.37 \mathrm{E}-06$ \\
\hline \multirow{6}{*}{$\begin{array}{l}\mathrm{SpG} \\
1.50 \text { and } \\
155^{\circ} \mathrm{F}\end{array}$} & Raw 241-AP-104 & 5611 & 68 & 28.0 & 0.62 & 0.53 & 0.07 & $2.15 \mathrm{E}-08$ & $5.09 \mathrm{E}-07$ & $1.43 \mathrm{E}-04$ & $1.76 \mathrm{E}-02$ & 5.15 & $3.70 \mathrm{E}-06$ \\
\hline & $2 \mathrm{AW}-0.25 / 4 \mathrm{AP}-0.75$ & 5611 & 68 & 28.0 & 0.62 & 0.53 & 0.07 & $2.23 \mathrm{E}-08$ & $5.75 \mathrm{E}-07$ & $5.53 \mathrm{E}-04$ & $1.33 \mathrm{E}-02$ & 4.73 & $3.80 \mathrm{E}-06$ \\
\hline & $2 \mathrm{AW}-0.45 / 4 \mathrm{AP}-0.55$ & 5611 & 68 & 28.0 & 0.62 & 0.53 & 0.07 & $2.26 \mathrm{E}-08$ & $6.18 \mathrm{E}-07$ & $5.81 \mathrm{E}-03$ & $9.83 \mathrm{E}-03$ & 4.42 & $3.88 \mathrm{E}-06$ \\
\hline & $2 \mathrm{AW}-0.5 / 4 \mathrm{AP}-0.5$ & 5611 & 68 & 28.0 & 0.62 & 0.53 & 0.07 & $2.25 \mathrm{E}-08$ & $6.27 \mathrm{E}-07$ & $4.55 \mathrm{E}-03$ & $8.97 \mathrm{E}-03$ & 4.34 & $3.90 \mathrm{E}-06$ \\
\hline & $2 \mathrm{AW}-1.0 / 4 \mathrm{AP}-0.0$ & 5611 & 68 & 28.0 & 0.62 & 0.53 & 0.07 & $2.10 \mathrm{E}-08$ & $6.67 \mathrm{E}-07$ & $1.30 \mathrm{E}-03$ & $2.98 \mathrm{E}-04$ & 3.67 & $4.09 \mathrm{E}-06$ \\
\hline & Raw 241-AW-102 & 5611 & 68 & 28.0 & 0.62 & 0.53 & 0.07 & $2.10 \mathrm{E}-08$ & $6.67 \mathrm{E}-07$ & $4.76 \mathrm{E}-04$ & $9.92 \mathrm{E}-04$ & 3.67 & $4.09 \mathrm{E}-06$ \\
\hline \multirow{6}{*}{$\begin{array}{l}\mathrm{SpG} \\
1.50 \text { and } \\
150^{\circ} \mathrm{F}\end{array}$} & Raw 241-AP-104 & 5611 & 66 & 27.8 & 0.62 & 0.53 & 0.07 & $1.91 \mathrm{E}-08$ & $3.93 \mathrm{E}-07$ & $1.43 \mathrm{E}-04$ & $1.76 \mathrm{E}-02$ & 5.14 & $3.71 \mathrm{E}-06$ \\
\hline & $2 \mathrm{AW}-0.25 / 4 \mathrm{AP}-0.75$ & 5611 & 66 & 27.8 & 0.62 & 0.53 & 0.07 & $1.98 \mathrm{E}-08$ & 4.44E-07 & $5.53 \mathrm{E}-04$ & $1.33 \mathrm{E}-02$ & 4.72 & $3.81 \mathrm{E}-06$ \\
\hline & $2 \mathrm{AW}-0.45 / 4 \mathrm{AP}-0.55$ & 5611 & 66 & 27.8 & 0.62 & 0.53 & 0.07 & $1.99 \mathrm{E}-08$ & 4.77E-07 & $5.81 \mathrm{E}-03$ & $9.83 \mathrm{E}-03$ & 4.41 & $3.89 \mathrm{E}-06$ \\
\hline & $2 \mathrm{AW}-0.5 / 4 \mathrm{AP}-0.5$ & 5611 & 66 & 27.8 & 0.62 & 0.53 & 0.07 & $1.99 \mathrm{E}-08$ & 4.84E-07 & $4.55 \mathrm{E}-03$ & $8.97 \mathrm{E}-03$ & 4.34 & $3.91 \mathrm{E}-06$ \\
\hline & $2 \mathrm{AW}-1.0 / 4 \mathrm{AP}-0.0$ & 5611 & 66 & 27.8 & 0.62 & 0.53 & 0.07 & $1.84 \mathrm{E}-08$ & $5.15 \mathrm{E}-07$ & $1.30 \mathrm{E}-03$ & $2.98 \mathrm{E}-04$ & 3.66 & $4.10 \mathrm{E}-06$ \\
\hline & Raw 241-AW-102 & 5611 & 66 & 27.8 & 0.62 & 0.53 & 0.07 & $1.84 \mathrm{E}-08$ & $5.15 \mathrm{E}-07$ & $4.76 \mathrm{E}-04$ & $9.92 \mathrm{E}-04$ & 3.66 & $4.10 \mathrm{E}-06$ \\
\hline
\end{tabular}

* Ammonia concentration used in flammability evaluation assumed to be $30 \%$ of original waste feed concentration. 
Table D-5. Results of Flammability Calculation of Liquid Feeds from Double-Shell Tanks 241-AP-104 and 241-AW-102. (2 sheets)

\begin{tabular}{|c|c|c|c|c|c|c|c|c|c|c|c|c|}
\hline \multicolumn{2}{|c|}{$\begin{array}{c}\text { Mixed Waste Case at Various SpG } \\
\text { and Waste Temperature }\end{array}$} & \multirow{2}{*}{$\begin{array}{c}\begin{array}{c}\text { Filled waste } \\
\text { fraction } \mathbf{f}\end{array} \\
0.62\end{array}$} & \multirow{2}{*}{$\begin{array}{c}\begin{array}{c}\text { RCcorr } \\
\mathbf{H}_{2} \text { from } \\
\text { Corrosion } \\
\left(\mathbf{m o l e} / \mathbf{m}^{3}-\mathbf{s}\right)\end{array} \\
1.88 \mathrm{E}-09\end{array}$} & \multirow{2}{*}{$\begin{array}{c}\begin{array}{c}\text { Ammonia } \\
\text { transport } \\
\text { constant k1 } \\
(\text { min-1) }\end{array} \\
5.63 \mathrm{E}-03 \\
\end{array}$} & \multirow{2}{*}{$\begin{array}{c}\begin{array}{c}\text { Ammonia } \\
\text { transport } \\
\text { constant k2 } \\
(\mathbf{M} / \mathbf{m i n})\end{array} \\
1.06 \mathrm{E}-06\end{array}$} & \multirow{2}{*}{ 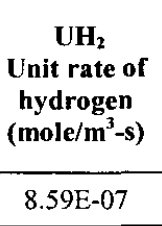 } & \multirow{2}{*}{ 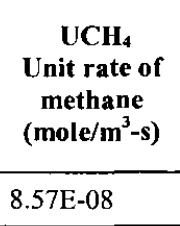 } & \multirow{2}{*}{$\begin{array}{c}\begin{array}{c}\text { Steady- } \\
\text { state EQ } \\
\text { NH }^{3} \\
\text { Concen. } \\
(\%)\end{array} \\
0.53\end{array}$} & \multirow{2}{*}{$\begin{array}{c}\begin{array}{c}\text { Steady } \\
\text { State } \\
\text { H2 LFL } \\
\text { (\%) }\end{array} \\
1895 \%\end{array}$} & \multirow{2}{*}{$\begin{array}{c}\begin{array}{c}\text { Steady } \\
\text { State CH} \\
\text { LFL (\%) }\end{array} \\
151 \% \\
\end{array}$} & \multirow{2}{*}{$\begin{array}{c}\begin{array}{c}\text { Steady } \\
\text { State NH } \\
\text { LFL (\%) }\end{array} \\
3.5 \% \\
\end{array}$} & \multirow{2}{*}{$\begin{array}{c}\begin{array}{c}\text { Steady } \\
\text { State LFL } \\
\text { at B.B. } \\
(\%)\end{array} \\
2049 \%\end{array}$} \\
\hline \multirow{6}{*}{$\begin{array}{c}\text { SpG } 1.6 \\
\text { and } \\
160^{\circ} \mathrm{F}\end{array}$} & Raw 241-AP-104 & & & & & & & & & & & \\
\hline & $2 \mathrm{AW}-0.25 / 4 \mathrm{AP}-0.75$ & 0.62 & $1.88 \mathrm{E}-09$ & $5.19 \mathrm{E}-03$ & $8.19 \mathrm{E}-07$ & $9.69 \mathrm{E}-07$ & $9.67 \mathrm{E}-08$ & 0.45 & $2137 \%$ & $171 \%$ & $3.0 \%$ & $2311 \%$ \\
\hline & $2 \mathrm{AW}-0.45 / 4 \mathrm{AP}-0.55$ & 0.62 & $1.88 \mathrm{E}-09$ & 4.85E-03 & $6.18 \mathrm{E}-07$ & $1.04 \mathrm{E}-06$ & $1.04 \mathrm{E}-07$ & 0.36 & $2290 \%$ & $183 \%$ & $2.4 \%$ & $2475 \%$ \\
\hline & $2 \mathrm{AW}-0.5 / 4 \mathrm{AP}-0.5$ & 0.62 & $1.88 \mathrm{E}-09$ & 4.77E-03 & $5.66 \mathrm{E}-07$ & $1.05 \mathrm{E}-06$ & $1.05 \mathrm{E}-07$ & 0.33 & $2322 \%$ & $185 \%$ & $2.2 \%$ & $2509 \%$ \\
\hline & $2 \mathrm{AW}-1.0 / 4 \mathrm{AP}-0.0$ & 0.62 & $1.88 \mathrm{E}-09$ & 4.01E-03 & $1.96 \mathrm{E}-08$ & $1.12 \mathrm{E}-06$ & $1.11 \mathrm{E}-07$ & 0.01 & $2463 \%$ & $197 \%$ & $0.1 \%$ & $2660 \%$ \\
\hline & Raw 241-AW-102 & 0.62 & $1.88 \mathrm{E}-09$ & 4.01E-03 & $6.53 \mathrm{E}-08$ & $1.12 \mathrm{E}-06$ & $1.11 \mathrm{E}-07$ & 0.05 & $2463 \%$ & $197 \%$ & $0.3 \%$ & $2660 \%$ \\
\hline \multirow{6}{*}{$\begin{array}{c}\text { SpG } 1.7 \\
\text { and } \\
155^{\circ} \mathrm{F}\end{array}$} & Raw 241-AP-104 & 0.62 & $1.89 \mathrm{E}-09$ & $4.21 \mathrm{E}-03$ & $1.17 \mathrm{E}-06$ & $8.11 \mathrm{E}-07$ & $8.09 \mathrm{E}-08$ & 0.78 & $1775 \%$ & $142 \%$ & $5.2 \%$ & $1922 \%$ \\
\hline & $2 \mathrm{AW}-0.25 / 4 \mathrm{AP}-0.75$ & 0.62 & $1.89 \mathrm{E}-09$ & $3.80 \mathrm{E}-03$ & $9.04 \mathrm{E}-07$ & $9.15 \mathrm{E}-07$ & $9.13 \mathrm{E}-08$ & 0.67 & $2002 \%$ & $160 \%$ & $4.4 \%$ & $2166 \%$ \\
\hline & $2 \mathrm{AW}-0.45 / 4 \mathrm{AP}-0.55$ & 0.62 & $1.89 \mathrm{E}-09$ & $3.49 \mathrm{E}-03$ & $6.79 \mathrm{E}-07$ & $9.80 \mathrm{E}-07$ & $9.78 \mathrm{E}-08$ & 0.54 & $2144 \%$ & $171 \%$ & $3.6 \%$ & $2319 \%$ \\
\hline & $2 \mathrm{AW}-0.5 / 4 \mathrm{AP}-0.5$ & 0.62 & $1.89 \mathrm{E}-09$ & $3.42 \mathrm{E}-03$ & $6.22 \mathrm{E}-07$ & $9.93 \mathrm{E}-07$ & $9.92 \mathrm{E}-08$ & 0.51 & $2174 \%$ & $174 \%$ & $3.4 \%$ & $2351 \%$ \\
\hline & $2 \mathrm{AW}-1.0 / 4 \mathrm{AP}-0.0$ & 0.62 & $1.89 \mathrm{E}-09$ & $2.75 \mathrm{E}-03$ & $2.14 \mathrm{E}-08$ & $1.05 \mathrm{E}-06$ & $1.05 \mathrm{E}-07$ & 0.02 & $2305 \%$ & $184 \%$ & $0.1 \%$ & $2489 \%$ \\
\hline & Raw 241-AW-102 & 0.62 & $1.89 \mathrm{E}-09$ & $2.75 \mathrm{E}-03$ & $7.12 \mathrm{E}-08$ & $1.05 \mathrm{E}-06$ & $1.05 \mathrm{E}-07$ & 0.07 & $2305 \%$ & $184 \%$ & $0.5 \%$ & $2489 \%$ \\
\hline \multirow{6}{*}{$\begin{array}{c}\mathrm{SpG} 1.6 \\
\text { and } \\
155^{\circ} \mathrm{F}\end{array}$} & Raw 241-AP-104 & 0.62 & $1.89 \mathrm{E}-09$ & $5.82 \mathrm{E}-03$ & $1.05 \mathrm{E}-06$ & $6.69 \mathrm{E}-07$ & $6.68 \mathrm{E}-08$ & 0.50 & $1465 \%$ & $117 \%$ & $3.4 \%$ & $1585 \%$ \\
\hline & $2 \mathrm{AW}-0.25 / 4 \mathrm{AP}-0.75$ & 0.62 & $1.89 \mathrm{E}-09$ & $5.37 \mathrm{E}-03$ & $8.11 \mathrm{E}-07$ & $7.55 \mathrm{E}-07$ & $7.53 \mathrm{E}-08$ & 0.42 & $1652 \%$ & $132 \%$ & $2.8 \%$ & $1786 \%$ \\
\hline & $2 \mathrm{AW}-0.45 / 4 \mathrm{AP}-0.55$ & 0.62 & $1.89 \mathrm{E}-09$ & $5.02 \mathrm{E}-03$ & $6.12 \mathrm{E}-07$ & $8.08 \mathrm{E}-07$ & $8.06 \mathrm{E}-08$ & 0.34 & $1769 \%$ & $141 \%$ & $2.3 \%$ & $1912 \%$ \\
\hline & $2 \mathrm{AW}-0.5 / 4 \mathrm{AP}-0.5$ & 0.62 & $1.89 \mathrm{E}-09$ & $4.94 \mathrm{E}-03$ & $5.60 \mathrm{E}-07$ & $8.19 \mathrm{E}-07$ & $8.18 \mathrm{E}-08$ & 0.32 & $1793 \%$ & $143 \%$ & $2.1 \%$ & $1938 \%$ \\
\hline & $2 \mathrm{AW}-1.0 / 4 \mathrm{AP}-0.0$ & 0.62 & $1.89 \mathrm{E}-09$ & 4.16E-03 & $1.94 \mathrm{E}-08$ & $8.69 \mathrm{E}-07$ & $8.67 \mathrm{E}-08$ & 0.01 & $1901 \%$ & $152 \%$ & $0.1 \%$ & $2053 \%$ \\
\hline & Raw 241-AW-102 & 0.62 & $1.89 \mathrm{E}-09$ & $4.16 \mathrm{E}-03$ & $6.48 \mathrm{E}-08$ & $8.69 \mathrm{E}-07$ & $8.67 \mathrm{E}-08$ & 0.04 & $1901 \%$ & $152 \%$ & $0.3 \%$ & $2053 \%$ \\
\hline \multirow{6}{*}{$\begin{array}{c}\text { SpG } 1.6 \\
\text { and } \\
150^{\circ} \mathrm{F}\end{array}$} & Raw 241-AP-104 & 0.62 & $1.91 \mathrm{E}-09$ & $5.75 \mathrm{E}-03$ & $1.05 \mathrm{E}-06$ & $5.20 \mathrm{E}-07$ & $5.18 \mathrm{E}-08$ & 0.51 & $1129 \%$ & $90 \%$ & $3.4 \%$ & $1222 \%$ \\
\hline & $2 \mathrm{AW}-0.25 / 4 \mathrm{AP}-0.75$ & 0.62 & $1.91 \mathrm{E}-09$ & $5.30 \mathrm{E}-03$ & $8.14 \mathrm{E}-07$ & $5.86 \mathrm{E}-07$ & $5.84 \mathrm{E}-08$ & 0.43 & $1272 \%$ & $101 \%$ & $2.8 \%$ & $1376 \%$ \\
\hline & $2 \mathrm{AW}-0.45 / 4 \mathrm{AP}-0.55$ & 0.62 & $1.91 \mathrm{E}-09$ & 4.96E-03 & $6.14 \mathrm{E}-07$ & $6.27 \mathrm{E}-07$ & $6.26 \mathrm{E}-08$ & 0.34 & $1362 \%$ & $109 \%$ & $2.3 \%$ & $1473 \%$ \\
\hline & $2 \mathrm{AW}-0.5 / 4 \mathrm{AP}-0.5$ & 0.62 & $1.91 \mathrm{E}-09$ & $4.88 \mathrm{E}-03$ & $5.62 \mathrm{E}-07$ & $6.36 \mathrm{E}-07$ & $6.34 \mathrm{E}-08$ & 0.32 & $1380 \%$ & $110 \%$ & $2.1 \%$ & $1493 \%$ \\
\hline & $2 \mathrm{AW}-1.0 / 4 \mathrm{AP}-0.0$ & 0.62 & $1.91 \mathrm{E}-09$ & $4.11 \mathrm{E}-03$ & $1.95 \mathrm{E}-08$ & $6.74 \mathrm{E}-07$ & $6.72 \mathrm{E}-08$ & 0.01 & $1463 \%$ & $117 \%$ & $0.1 \%$ & $1579 \%$ \\
\hline & Raw 241-AW-102 & 0.62 & $1.91 \mathrm{E}-09$ & $4.11 E-03$ & $6.50 \mathrm{E}-08$ & $6.74 \mathrm{E}-07$ & $6.72 \mathrm{E}-08$ & 0.04 & $1463 \%$ & $117 \%$ & $0.3 \%$ & $1579 \%$ \\
\hline
\end{tabular}


Table D-5. Results of Flammability Calculation of Liquid Feeds from Double-Shell Tanks 241-AP-104 and 241-AW-102. (2 sheets)

\begin{tabular}{|c|c|c|c|c|c|c|c|c|c|c|c|c|}
\hline \multicolumn{2}{|c|}{$\begin{array}{c}\text { Mixed Waste Case at Various SpG } \\
\text { and Waste Temperature }\end{array}$} & \multirow{2}{*}{$\begin{array}{c}\begin{array}{c}\text { Filled waste } \\
\text { fraction } \mathbf{f}\end{array} \\
0.62\end{array}$} & \multirow{2}{*}{ 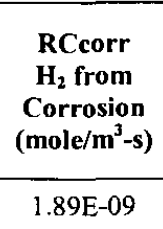 } & \multirow{2}{*}{$\begin{array}{c}\begin{array}{c}\text { Ammonia } \\
\text { transport } \\
\text { constant k1 } \\
(\mathbf{m i n}-1)\end{array} \\
6.76 \mathrm{E}-03\end{array}$} & \multirow{2}{*}{$\begin{array}{c}\begin{array}{c}\text { Ammonia } \\
\text { transport } \\
\text { constant k2 } \\
\text { (M/min) }\end{array} \\
9.77 \mathrm{E}-07\end{array}$} & \multirow{2}{*}{$\begin{array}{c}\begin{array}{c}\mathrm{UH}_{2} \\
\text { Unit rate of } \\
\text { hydrogen } \\
\left(\mathbf{m o l e} / \mathbf{m}^{3}-\mathbf{s}\right)\end{array} \\
6.00 \mathrm{E}-07\end{array}$} & \multirow{2}{*}{$\begin{array}{c}\begin{array}{c}\mathrm{UCH}_{4} \\
\begin{array}{c}\text { Unit rate of } \\
\text { methane } \\
\left(\mathbf{m o l e} / \mathbf{m}^{3}-\mathbf{s}\right)\end{array}\end{array} \\
5.98 \mathrm{E}-08\end{array}$} & \multirow{2}{*}{$\begin{array}{c}\begin{array}{c}\text { Steady- } \\
\text { state EQ } \\
\text { NH }^{3} \\
\text { Concen. } \\
\text { (\%) }\end{array} \\
0.40\end{array}$} & \multirow{2}{*}{$\begin{array}{c}\begin{array}{c}\text { Steady } \\
\text { State } \\
\text { H2 LFL } \\
\text { (\%) }\end{array} \\
1313 \%\end{array}$} & \multirow{2}{*}{$\begin{array}{c}\begin{array}{c}\text { Steady } \\
\text { State CH } \\
\text { LFL (\%) }\end{array} \\
105 \%\end{array}$} & \multirow{2}{*}{\begin{tabular}{|c} 
Steady \\
State NH \\
LFL (\%)
\end{tabular}} & \multirow{2}{*}{\begin{tabular}{|c}
$\begin{array}{c}\text { Steady } \\
\text { State LFL } \\
\text { at B.B. } \\
\text { (\%) }\end{array}$ \\
$1421 \%$ \\
\end{tabular}} \\
\hline \multirow{6}{*}{$\begin{array}{c}\text { SpG } 1.55 \\
\text { and } \\
155^{\circ} \mathrm{F}\end{array}$} & Raw 241-AP-104 & & & & & & & & & & & \\
\hline & $2 \mathrm{AW}-0.25 / 4 \mathrm{AP}-0.75$ & 0.62 & $1.89 \mathrm{E}-09$ & $6.30 \mathrm{E}-03$ & $7.58 \mathrm{E}-07$ & $6.77 \mathrm{E}-07$ & $6.75 \mathrm{E}-08$ & 0.34 & $1480 \%$ & $118 \%$ & $2.2 \%$ & $1601 \%$ \\
\hline & $2 \mathrm{AW}-0.45 / 4 \mathrm{AP}-0.55$ & 0.62 & $1.89 \mathrm{E}-09$ & $5.95 \mathrm{E}-03$ & $5.73 \mathrm{E}-07$ & $7.25 \mathrm{E}-07$ & $7.23 \mathrm{E}-08$ & 0.27 & $1585 \%$ & $127 \%$ & $1.8 \%$ & $1714 \%$ \\
\hline & $2 \mathrm{AW}-0.5 / 4 \mathrm{AP}-0.5$ & 0.62 & $1.89 \mathrm{E}-09$ & $5.86 \mathrm{E}-03$ & $5.25 \mathrm{E}-07$ & $7.34 \mathrm{E}-07$ & $7.33 \mathrm{E}-08$ & 0.25 & $1607 \%$ & $128 \%$ & $1.7 \%$ & $1737 \%$ \\
\hline & $2 \mathrm{AW}-1.0 / 4 \mathrm{AP}-0.0$ & 0.62 & $1.89 \mathrm{E}-09$ & $5.05 \mathrm{E}-03$ & $1.83 \mathrm{E}-08$ & $7.79 \mathrm{E}-07$ & $7.77 \mathrm{E}-08$ & 0.01 & $1704 \%$ & $136 \%$ & $0.1 \%$ & $1840 \%$ \\
\hline & Raw 241-AW-102 & 0.62 & $1.89 \mathrm{E}-09$ & $5.05 \mathrm{E}-03$ & $6.10 \mathrm{E}-08$ & $7.79 \mathrm{E}-07$ & $7.77 \mathrm{E}-08$ & 0.03 & $1704 \%$ & $136 \%$ & $0.2 \%$ & $1840 \%$ \\
\hline \multirow{6}{*}{$\begin{array}{c}\text { SpG } 1.55 \\
\text { and } \\
150^{\circ} \mathrm{F}\end{array}$} & Raw 241-AP-104 & 0.62 & $1.91 \mathrm{E}-09$ & $6.69 \mathrm{E}-03$ & $9.81 \mathrm{E}-07$ & $4.66 \mathrm{E}-07$ & $4.65 \mathrm{E}-08$ & 0.41 & $1012 \%$ & $81 \%$ & $2.7 \%$ & $1096 \%$ \\
\hline & $2 \mathrm{AW}-0.25 / 4 \mathrm{AP}-0.75$ & 0.62 & $1.91 \mathrm{E}-09$ & $6.23 \mathrm{E}-03$ & $7.62 \mathrm{E}-07$ & $5.25 \mathrm{E}-07$ & $5.23 \mathrm{E}-08$ & 0.34 & $1140 \%$ & $91 \%$ & $2.3 \%$ & $1233 \%$ \\
\hline & $2 \mathrm{AW}-0.45 / 4 \mathrm{AP}-0.55$ & 0.62 & $1.91 \mathrm{E}-09$ & $5.88 \mathrm{E}-03$ & $5.75 \mathrm{E}-07$ & $5.62 \mathrm{E}-07$ & $5.61 \mathrm{E}-08$ & 0.27 & $1221 \%$ & $97 \%$ & $1.8 \%$ & $1320 \%$ \\
\hline & $2 \mathrm{AW}-0.5 / 4 \mathrm{AP}-0.5$ & 0.62 & $1.91 \mathrm{E}-09$ & $5.80 \mathrm{E}-03$ & $5.27 \mathrm{E}-07$ & $5.70 \mathrm{E}-07$ & $5.68 \mathrm{E}-08$ & 0.25 & $1237 \%$ & $99 \%$ & $1.7 \%$ & $1338 \%$ \\
\hline & $2 \mathrm{AW}-1.0 / 4 \mathrm{AP}-0.0$ & 0.62 & $1.91 \mathrm{E}-09$ & $4.99 \mathrm{E}-03$ & $1.84 \mathrm{E}-08$ & $6.04 \mathrm{E}-07$ & $6.02 \mathrm{E}-08$ & 0.01 & $1311 \%$ & $105 \%$ & $0.1 \%$ & $1415 \%$ \\
\hline & Raw 241-AW-102 & 0.62 & $1.91 \mathrm{E}-09$ & $4.99 \mathrm{E}-03$ & $6.12 \mathrm{E}-08$ & $6.04 \mathrm{E}-07$ & $6.02 \mathrm{E}-08$ & 0.03 & $1311 \%$ & $105 \%$ & $0.2 \%$ & $1416 \%$ \\
\hline \multirow{6}{*}{$\begin{array}{c}\mathrm{SpG} 1.50 \\
\text { and } \\
155^{\circ} \mathrm{F}\end{array}$} & Raw 241-AP-104 & 0.62 & $1.89 \mathrm{E}-09$ & $7.51 \mathrm{E}-03$ & $9.19 \mathrm{E}-07$ & $5.32 \mathrm{E}-07$ & $5.30 \mathrm{E}-08$ & 0.34 & $1164 \%$ & $93 \%$ & $2.3 \%$ & $1259 \%$ \\
\hline & $2 \mathrm{AW}-0.25 / 4 \mathrm{AP}-0.75$ & 0.62 & $1.89 \mathrm{E}-09$ & $7.10 \mathrm{E}-03$ & $7.13 \mathrm{E}-07$ & $6.00 \mathrm{E}-07$ & $5.98 \mathrm{E}-08$ & 0.28 & $1312 \%$ & $105 \%$ & $1.9 \%$ & $1419 \%$ \\
\hline & $2 \mathrm{AW}-0.45 / 4 \mathrm{AP}-0.55$ & 0.62 & $1.89 \mathrm{E}-09$ & $6.77 \mathrm{E}-03$ & $5.38 \mathrm{E}-07$ & $6.42 \mathrm{E}-07$ & $6.40 \mathrm{E}-08$ & 0.22 & $1405 \%$ & $112 \%$ & $1.5 \%$ & $1519 \%$ \\
\hline & $2 \mathrm{AW}-0.5 / 4 \mathrm{AP}-0.5$ & 0.62 & $1.89 \mathrm{E}-09$ & $6.70 \mathrm{E}-03$ & $4.93 \mathrm{E}-07$ & $6.51 \mathrm{E}-07$ & $6.49 \mathrm{E}-08$ & 0.21 & $1425 \%$ & $114 \%$ & $1.4 \%$ & $1540 \%$ \\
\hline & $2 \mathrm{AW}-1.0 / 4 \mathrm{AP}-0.0$ & 0.62 & $1.89 \mathrm{E}-09$ & $5.93 \mathrm{E}-03$ & $1.72 \mathrm{E}-08$ & $6.90 \mathrm{E}-07$ & $6.88 \mathrm{E}-08$ & 0.01 & $1510 \%$ & $120 \%$ & $0.1 \%$ & $1631 \%$ \\
\hline & Raw 241-AW-102 & 0.62 & $1.89 \mathrm{E}-09$ & $5.93 \mathrm{E}-03$ & $5.72 \mathrm{E}-08$ & $6.90 \mathrm{E}-07$ & $6.88 \mathrm{E}-08$ & 0.03 & $1510 \%$ & $120 \%$ & $0.2 \%$ & $1631 \%$ \\
\hline \multirow{6}{*}{$\begin{array}{c}\text { SpG } 1.50 \\
\text { and } \\
150^{\circ} \mathrm{F}\end{array}$} & Raw 241-AP-104 & 0.62 & $1.91 \mathrm{E}-09$ & $7.47 \mathrm{E}-03$ & $9.22 \mathrm{E}-07$ & $4.14 \mathrm{E}-07$ & $4.12 \mathrm{E}-08$ & 0.34 & $898 \%$ & $71 \%$ & $2.3 \%$ & $972 \%$ \\
\hline & $2 \mathrm{AW}-0.25 / 4 \mathrm{AP}-0.75$ & 0.62 & $1.91 \mathrm{E}-09$ & $7.05 \mathrm{E}-03$ & $7.15 \mathrm{E}-07$ & $4.66 \mathrm{E}-07$ & $4.64 \mathrm{E}-08$ & 0.28 & $1011 \%$ & $81 \%$ & $1.9 \%$ & $1093 \%$ \\
\hline & $2 \mathrm{AW}-0.45 / 4 \mathrm{AP}-0.55$ & 0.62 & $1.91 \mathrm{E}-09$ & $6.73 \mathrm{E}-03$ & $5.40 \mathrm{E}-07$ & $4.99 \mathrm{E}-07$ & $4.97 \mathrm{E}-08$ & 0.22 & $1082 \%$ & $86 \%$ & $1.5 \%$ & $1170 \%$ \\
\hline & $2 \mathrm{AW}-0.5 / 4 \mathrm{AP}-0.5$ & 0.62 & $1.91 \mathrm{E}-09$ & $6.65 \mathrm{E}-03$ & 4.95E-07 & $5.05 \mathrm{E}-07$ & $5.03 \mathrm{E}-08$ & 0.21 & $1097 \%$ & $87 \%$ & $1.4 \%$ & $1186 \%$ \\
\hline & $2 \mathrm{AW}-1.0 / 4 \mathrm{AP}-0.0$ & 0.62 & $1.91 \mathrm{E}-09$ & $5.88 \mathrm{E}-03$ & $1.72 \mathrm{E}-08$ & $5.35 \mathrm{E}-07$ & $5.33 \mathrm{E}-08$ & 0.01 & $1162 \%$ & $93 \%$ & $0.1 \%$ & $1254 \%$ \\
\hline & Raw 241-AW-102 & 0.62 & $1.91 \mathrm{E}-09$ & $5.88 \mathrm{E}-03$ & $5.74 \mathrm{E}-08$ & $5.35 \mathrm{E}-07$ & $5.33 \mathrm{E}-08$ & 0.03 & $1162 \%$ & $93 \%$ & $0.2 \%$ & $1255 \%$ \\
\hline
\end{tabular}


Table D-6. Results of Time to $25 \%$ and $100 \%$ of the Lower Flammability Limit Calculation of Liquid Feeds from Double-Shell Tanks 241-AP-104 and 241-AW-102. (2 sheets)

\begin{tabular}{|c|c|c|c|c|c|c|c|c|c|c|}
\hline \multicolumn{2}{|c|}{$\begin{array}{l}\text { Mixed Waste Case at various SpG and } \\
\text { waste Temperature }\end{array}$} & \multirow{2}{*}{$\begin{array}{c}\begin{array}{c}\text { Filled waste } \\
\text { fraction } \mathbf{f}\end{array} \\
0.62\end{array}$} & \multirow{2}{*}{$\begin{array}{c}\begin{array}{c}\text { Time to } \\
\text { Reach } \\
\text { 25\% LFL at } \\
\text { BB Vent } \\
\text { (days) }\end{array} \\
2.34 \\
\end{array}$} & \multirow{2}{*}{$\begin{array}{c}\begin{array}{c}\text { Time to } \\
\text { Reach }\end{array} \\
\text { 100\% LFL } \\
\text { at BB Vent } \\
\text { (days) }\end{array}$} & \multirow{2}{*}{$\begin{array}{c}\begin{array}{c}\text { Time to } \\
\text { Reach } \\
\text { 25\% LFL at } \\
\text { Zero Vent } \\
\text { (days) }\end{array} \\
2.33 \\
\end{array}$} & \multirow{2}{*}{$\begin{array}{c}\begin{array}{c}\text { Time to } \\
\text { Reach } \\
\mathbf{1 0 0 \% \text { LFL }} \\
\text { at Zero Vent } \\
\text { (days) }\end{array} \\
10.47 \\
\end{array}$} & \multirow{2}{*}{$\begin{array}{c}\begin{array}{c}\text { Vent Rate } \\
\text { keep Below } \\
\text { 25\% LFL } \\
\text { DomeVol\% } \\
\text { per day }\end{array} \\
42.9 \% \\
\end{array}$} & \multirow{2}{*}{$\begin{array}{c}\begin{array}{c}\text { Vent Rate } \\
\text { Keep Below } \\
\text { 25\% LFL } \\
\text { (cfh) }\end{array} \\
38.2\end{array}$} & \multirow{2}{*}{$\begin{array}{c}\begin{array}{c}\text { Vent Rate } \\
\text { Keep Below } \\
\text { 100\% LFL } \\
\text { DomeVol\% } \\
\text { per day }\end{array} \\
9.5 \% \\
\end{array}$} & \multirow{2}{*}{$\begin{array}{c}\begin{array}{c}\text { Vent Rate } \\
\text { Keep Below } \\
\text { 100\% LFL } \\
\text { (cfh) }\end{array} \\
8.5 \\
\end{array}$} \\
\hline \multirow{6}{*}{$\begin{array}{l}\text { SpG } 1.6 \\
\text { and } \\
160^{\circ} \mathrm{F}\end{array}$} & Raw 241-AP-104 & & & & & & & & & \\
\hline & $2 \mathrm{AW}-0.25 / 4 \mathrm{AP}-0.75$ & 0.62 & 2.13 & 9.5 & 2.12 & 9.34 & $47.1 \%$ & 41.9 & $10.7 \%$ & 9.5 \\
\hline & $2 \mathrm{AW}-0.45 / 4 \mathrm{AP}-0.55$ & 0.62 & 2.04 & 8.9 & 2.03 & 8.77 & $49.2 \%$ & 43.8 & $11.4 \%$ & 10.1 \\
\hline & $2 \mathrm{AW}-0.5 / 4 \mathrm{AP}-0.5$ & 0.62 & 2.02 & 8.8 & 2.01 & 8.66 & $49.5 \%$ & 44.1 & $11.5 \%$ & 10.3 \\
\hline & $2 \mathrm{AW}-1.0 / 4 \mathrm{AP}-0.0$ & 0.62 & 2.09 & 8.5 & 2.08 & 8.34 & $48.0 \%$ & 42.7 & $12.0 \%$ & 10.7 \\
\hline & Raw 241-AW-102 & 0.62 & 2.07 & 8.5 & 2.06 & 8.33 & $48.5 \%$ & 43.1 & $12.0 \%$ & 10.7 \\
\hline \multirow{6}{*}{$\begin{array}{l}\text { SpG } 1.7 \\
\text { and } \\
155^{\circ} \mathrm{F}\end{array}$} & Raw 241-AP-104 & 0.62 & 2.30 & 11.3 & 2.29 & 10.99 & $43.5 \%$ & 38.7 & $9.1 \%$ & 8.1 \\
\hline & $2 \mathrm{AW}-0.25 / 4 \mathrm{AP}-0.75$ & 0.62 & 2.12 & 10.0 & 2.11 & 9.82 & $47.3 \%$ & 42.1 & $10.2 \%$ & 9.1 \\
\hline & $2 \mathrm{AW}-0.45 / 4 \mathrm{AP}-0.55$ & 0.62 & 2.06 & 9.4 & 2.05 & 9.24 & $48.8 \%$ & 43.4 & $10.8 \%$ & 9.6 \\
\hline & $2 \mathrm{AW}-0.5 / 4 \mathrm{AP}-0.5$ & 0.62 & 2.05 & 9.3 & 2.04 & 9.14 & $48.9 \%$ & 43.5 & $10.9 \%$ & 9.7 \\
\hline & $2 \mathrm{AW}-1.0 / 4 \mathrm{AP}-0.0$ & 0.62 & 2.23 & 9.1 & 2.21 & 8.91 & $45.1 \%$ & 40.1 & $11.2 \%$ & 10.0 \\
\hline & Raw 241-AW-102 & 0.62 & 2.19 & 9.1 & 2.18 & 8.88 & $45.7 \%$ & 40.6 & $11.3 \%$ & 10.0 \\
\hline \multirow{6}{*}{$\begin{array}{c}\text { SpG } 1.6 \\
\text { and } \\
155^{\circ} \mathrm{F}\end{array}$} & Raw 241-AP-104 & 0.62 & 3.06 & 14.0 & 3.04 & 13.57 & $32.9 \%$ & 29.3 & $7.4 \%$ & 6.6 \\
\hline & $2 \mathrm{AW}-0.25 / 4 \mathrm{AP}-0.75$ & 0.62 & 2.78 & 12.5 & 2.76 & 12.11 & $36.2 \%$ & 32.2 & $8.3 \%$ & 7.3 \\
\hline & $2 \mathrm{AW}-0.45 / 4 \mathrm{AP}-0.55$ & 0.62 & 2.65 & 11.7 & 2.64 & 11.37 & $37.8 \%$ & 33.6 & $8.8 \%$ & 7.8 \\
\hline & $2 \mathrm{AW}-0.5 / 4 \mathrm{AP}-0.5$ & 0.62 & 2.64 & 11.5 & 2.62 & 11.23 & $38.1 \%$ & 33.9 & $8.9 \%$ & 7.9 \\
\hline & $2 \mathrm{AW}-1.0 / 4 \mathrm{AP}-0.0$ & 0.62 & 2.71 & 11.1 & 2.69 & 10.81 & $37.1 \%$ & 33.0 & $9.2 \%$ & 8.2 \\
\hline & Raw 241-AP-104 & 0.62 & 2.69 & 11.1 & 2.67 & 10.79 & $37.4 \%$ & 33.3 & $9.3 \%$ & 8.2 \\
\hline \multirow{6}{*}{$\begin{array}{c}\text { SpG 1.6 } \\
\text { and } \\
150^{\circ} \mathrm{F}\end{array}$} & $2 \mathrm{AW}-0.25 / 4 \mathrm{AP}-0.75$ & 0.62 & 3.97 & 18.4 & 3.94 & 17.61 & $25.4 \%$ & 22.6 & $5.7 \%$ & 5.1 \\
\hline & $2 \mathrm{AW}-0.45 / 4 \mathrm{AP}-0.55$ & 0.62 & 3.61 & 16.3 & 3.58 & 15.72 & $27.9 \%$ & 24.8 & $6.4 \%$ & 5.7 \\
\hline & $2 \mathrm{AW}-0.5 / 4 \mathrm{AP}-0.5$ & 0.62 & 3.45 & 15.3 & 3.43 & 14.76 & $29.1 \%$ & 25.9 & $6.8 \%$ & 6.0 \\
\hline & $2 \mathrm{AW}-1.0 / 4 \mathrm{AP}-0.0$ & 0.62 & 3.43 & 15.1 & 3.40 & 14.59 & $29.3 \%$ & 26.1 & $6.9 \%$ & 6.1 \\
\hline & Raw 241-AW-102 & 0.62 & 3.53 & 14.5 & 3.50 & 14.06 & $28.5 \%$ & 25.4 & $7.1 \%$ & 6.3 \\
\hline & Raw 241-AP-104 & 0.62 & 3.50 & 14.5 & 3.47 & 14.03 & $28.8 \%$ & 25.6 & $7.1 \%$ & 6.3 \\
\hline
\end{tabular}


Table D-6. Results of Time to $25 \%$ and $100 \%$ of the Lower Flammability Limit Calculation of Liquid Feeds from Double-Shell Tanks 241-AP-104 and 241-AW-102. (2 sheets)

\begin{tabular}{|c|c|c|c|c|c|c|c|c|c|c|}
\hline \multicolumn{2}{|c|}{$\begin{array}{l}\text { Mixed Waste Case at various SpG and } \\
\text { waste Temperature }\end{array}$} & \multirow{2}{*}{$\begin{array}{c}\begin{array}{c}\text { Filled waste } \\
\text { fraction } \mathbf{f}\end{array} \\
0.62\end{array}$} & \multirow{2}{*}{$\begin{array}{c}\begin{array}{c}\text { Time to } \\
\text { Reach } \\
\text { 25\% LFL at } \\
\text { BB Vent } \\
\text { (days) }\end{array} \\
3.52\end{array}$} & \multirow{2}{*}{$\begin{array}{c}\begin{array}{c}\text { Time to } \\
\text { Reach }\end{array} \\
\begin{array}{c}\text { 100\% LFL } \\
\text { at BB Vent } \\
\text { (days) }\end{array} \\
15.8\end{array}$} & \multirow{2}{*}{$\begin{array}{c}\begin{array}{c}\text { Time to } \\
\text { Reach } \\
\text { 25\% LFL at } \\
\text { Zero Vent } \\
\text { (days) }\end{array} \\
3.49\end{array}$} & \multirow{2}{*}{$\begin{array}{c}\begin{array}{c}\text { Time to } \\
\text { Reach } \\
\text { 100\% LFL } \\
\text { at Zero Vent } \\
\text { (days) }\end{array} \\
15.25\end{array}$} & \multirow{2}{*}{$\begin{array}{c}\begin{array}{c}\text { Vent Rate } \\
\text { keep Below } \\
25 \% \text { LFL } \\
\text { DomeVol\% } \\
\text { per day }\end{array} \\
28.6 \%\end{array}$} & \multirow{2}{*}{$\begin{array}{c}\begin{array}{c}\text { Vent Rate } \\
\text { Keep Below } \\
\text { 25\% LFL } \\
\text { (cfh) }\end{array} \\
25.5\end{array}$} & \multirow{2}{*}{ 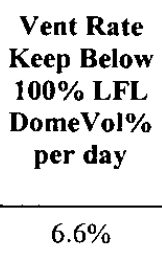 } & \multirow{2}{*}{$\begin{array}{c}\begin{array}{c}\text { Vent Rate } \\
\text { Keep Below } \\
\text { 100\% LFL } \\
\text { (cfh) }\end{array} \\
5.8\end{array}$} \\
\hline \multirow{6}{*}{$\begin{array}{c}\text { SpG } 1.55 \\
\text { and } \\
155^{\circ} \mathrm{F}\end{array}$} & Raw 241-AP-104 & & & & & & & & & \\
\hline & $2 \mathrm{AW}-0.25 / 4 \mathrm{AP}-0.75$ & 0.62 & 3.18 & 14.0 & 3.16 & 13.59 & $31.6 \%$ & 28.1 & $7.4 \%$ & 6.5 \\
\hline & $2 \mathrm{AW}-0.45 / 4 \mathrm{AP}-0.55$ & 0.62 & 3.03 & 13.1 & 3.01 & 12.74 & $33.2 \%$ & 29.5 & $7.8 \%$ & 7.0 \\
\hline & $2 \mathrm{AW}-0.5 / 4 \mathrm{AP}-0.5$ & 0.62 & 3.00 & 13.0 & 2.98 & 12.59 & $33.5 \%$ & 29.8 & $7.9 \%$ & 7.1 \\
\hline & $2 \mathrm{AW}-1.0 / 4 \mathrm{AP}-0.0$ & 0.62 & 3.03 & 12.4 & 3.01 & 12.07 & $33.2 \%$ & 29.5 & $8.3 \%$ & 7.4 \\
\hline & Raw 241-AW-102 & 0.62 & 3.01 & 12.4 & 2.99 & 12.05 & $33.4 \%$ & 29.7 & $8.3 \%$ & 7.4 \\
\hline \multirow{6}{*}{$\begin{array}{c}\text { SpG } 1.55 \\
\text { and } \\
150^{\circ} \mathrm{F}\end{array}$} & Raw 241-AP-104 & 0.62 & 4.57 & 20.7 & 4.53 & 19.78 & $22.1 \%$ & 19.6 & $5.1 \%$ & 4.5 \\
\hline & $2 \mathrm{AW}-0.25 / 4 \mathrm{AP}-0.75$ & 0.62 & 4.14 & 18.4 & 4.10 & 17.64 & $24.4 \%$ & 21.7 & $5.7 \%$ & 5.0 \\
\hline & $2 \mathrm{AW}-0.45 / 4 \mathrm{AP}-0.55$ & 0.62 & 3.94 & 17.2 & 3.90 & 16.55 & $25.6 \%$ & 22.8 & $6.0 \%$ & 5.4 \\
\hline & $2 \mathrm{AW}-0.5 / 4 \mathrm{AP}-0.5$ & 0.62 & 3.91 & 17.0 & 3.87 & 16.35 & $25.8 \%$ & 22.9 & $6.1 \%$ & 5.4 \\
\hline & $2 \mathrm{AW}-1.0 / 4 \mathrm{AP}-0.0$ & 0.62 & 3.94 & 16.3 & 3.91 & 15.69 & $25.5 \%$ & 22.7 & $6.4 \%$ & 5.7 \\
\hline & Raw 241-AW-102 & 0.62 & 3.92 & 16.2 & 3.88 & 15.66 & $25.7 \%$ & 22.9 & $6.4 \%$ & 5.7 \\
\hline \multirow{6}{*}{$\begin{array}{c}\text { SpG } 1.50 \\
\text { and } \\
155^{\circ} \mathrm{F}\end{array}$} & Raw 241-AP-104 & 0.62 & 4.05 & 18.0 & 4.01 & 17.27 & $24.9 \%$ & 22.2 & $5.8 \%$ & 5.2 \\
\hline & $2 \mathrm{AW}-0.25 / 4 \mathrm{AP}-0.75$ & 0.62 & 3.65 & 15.9 & 3.62 & 15.39 & $27.6 \%$ & 24.5 & $6.5 \%$ & 5.8 \\
\hline & $2 \mathrm{AW}-0.45 / 4 \mathrm{AP}-0.55$ & 0.62 & 3.47 & 14.9 & 3.44 & 14.42 & $29.0 \%$ & 25.8 & $6.9 \%$ & 6.2 \\
\hline & $2 \mathrm{AW}-0.5 / 4 \mathrm{AP}-0.5$ & 0.62 & 3.43 & 14.7 & 3.41 & 14.24 & $29.3 \%$ & 26.1 & $7.0 \%$ & 6.2 \\
\hline & $2 \mathrm{AW}-1.0 / 4 \mathrm{AP}-0.0$ & 0.62 & 3.42 & 14.1 & 3.39 & 13.62 & $29.4 \%$ & 26.2 & $7.3 \%$ & 6.5 \\
\hline & Raw 241-AW-102 & 0.62 & 3.40 & 14.0 & 3.38 & 13.60 & $29.6 \%$ & 26.3 & $7.4 \%$ & 6.5 \\
\hline \multirow{6}{*}{$\begin{array}{c}\mathrm{SpG} 1.50 \\
\text { and } \\
150^{\circ} \mathrm{F}\end{array}$} & Raw 241-AP-104 & 0.62 & 5.26 & 23.6 & 5.20 & 22.40 & $19.2 \%$ & 17.1 & $4.5 \%$ & 4.0 \\
\hline & $2 \mathrm{AW}-0.25 / 4 \mathrm{AP}-0.75$ & 0.62 & 4.75 & 20.9 & 4.70 & 19.97 & $21.2 \%$ & 18.9 & $5.0 \%$ & 4.5 \\
\hline & $2 \mathrm{AW}-0.45 / 4 \mathrm{AP}-0.55$ & 0.62 & 4.51 & 19.6 & 4.47 & 18.73 & $22.4 \%$ & 19.9 & $5.3 \%$ & 4.7 \\
\hline & $2 \mathrm{AW}-0.5 / 4 \mathrm{AP}-0.5$ & 0.62 & 4.47 & 19.3 & 4.43 & 18.50 & $22.6 \%$ & 20.1 & $5.4 \%$ & 4.8 \\
\hline & $2 \mathrm{AW}-1.0 / 4 \mathrm{AP}-0.0$ & 0.62 & 4.46 & 18.5 & 4.41 & 17.70 & $22.6 \%$ & 20.1 & $5.6 \%$ & 5.0 \\
\hline & Raw 241-AW-102 & 0.62 & 4.44 & 18.4 & 4.39 & 17.68 & $22.7 \%$ & 20.2 & $5.7 \%$ & 5.0 \\
\hline
\end{tabular}


RPP-CALC-29700 REV 1

APPENDIX E

FLAMMABILITY ANALYSIS FOR 242-A EVAPORATOR UNDER SHUTDOWN MODE AND WATER STARTUP OPERATION 
RPP-CALC-29700 REV 1

This page intentionally left blank.

E-ii 


\section{APPENDIX E \\ FLAMMABILITY ANALYSIS FOR 242-A EVAPORATOR UNDER SHUTDOWN MODE AND WATER STARTUP OPERATION}

In shutdown mode, the C-A-1 evaporator vessel and recirculation loop are allowed to contain 10,000 gal water, antifoaming agents (AFA), process condensate, and/or inhibited water (i.e., water treated with hydroxide and/or nitrites used for corrosion control) which may be added to support maintenance or testing activities. For startup of the 242-A Evaporator, the C-A-1 evaporator vessel is filled with water, heated up, and AFA is added prior to receiving waste feed.

This appendix documents the evaluations to calculate the times to $25 \%$ and $100 \%$ of the lower flammability limit (LFL) for the 242-A Evaporator vessel under the following bounding conditions:

- 10,000 gal of process condensate in the C-A-1 evaporator vessel mixed with 165 gal of AFA at room temperature $\left(59^{\circ} \mathrm{F}\right)$ during the shutdown mode

- C-A-1 evaporator vessel filled with process condensate (26,000 gal) mixed with 165 gal of AFA at $160^{\circ} \mathrm{F}$ for the water startup mode for evaporator operation prior to introduction of liquid waste feed.

- In both analyses, 165 gal AFA liquid is used because 165 gal is the estimated upper bounding volume for the AFA addition for each evaporator vessel fill.

The calculation shows that the time to reach $25 \%$ of the LFL at zero ventilation is longer than 1,000 days for both conditions. The inhibited water case has been evaluated, and the conclusion is that the time to $25 \%$ of the LFL is bounded by the process condensate case calculations.

The methodology used in this analysis is taken from RPP-5926, Steady-State Flammable Gas Release Rate Calculation and Lower Flammability Level Evaluation for Hanford Tank Waste, and RPP-8050, Lower Flammability Limit Calculations for Catch Tanks, IMUSTs, DST Annuli, Pit Structures, and Double-Contained Receiver Tanks in Tank Farms at the Hanford Site, and summarized in Chapter 6.0 of this document. Gas generation rate calculation uses the process condensate sample results of 242-A Evaporator 06-01 campaign (RPP-PLAN-27610, Process Control Plan for 242-A Evaporator Campaigns 06-CR (Cold Run), and Tank Waste Information Network System (TWINS) database, condensate sample, September 5, 2006). The input data for gas generation rate calculations are given in Table E-1. In the input data preparation, the concentrations of chemicals and radionuclides, the density and the weight percent water conservatively are assumed the same as for process condensate except the TOC, which is a weighted averaged of the process condensate and AFA liquid concentrations. The validated Microsoft Excel ${ }^{4}$ spreadsheets listed in Chapter 7.0 are used for both gas generation rate

\footnotetext{
${ }^{4}$ Microsoft Excel is a trademark of Microsoft Corporation, Redmond, Washington.
} 
calculations and flammability analyses. Tables E-2 and E-3 list the calculated unit generation rates of thermolysis and radiolysis. Table E-4 lists the input data and Tables E-5 and E- 6 list the calculation results of the flammability analyses.

As shown in Table E-3, the hydrogen generation rate is dominated by the corrosion rate since the process condensate is low in TOC and low in radionuclides. As shown in Table E-4, for both cases, the time to reach $25 \%$ of the LFL under zero ventilation is greater than 1,000 days (note that the calculation is terminated at 2,000 days). For the inhibited water case, the zero radiation dose and low ammonia concentration will result in the generation of less gas compared to process condensate waste, thus it is bounded by the process condensate calculations. Overall, the low radiation dose and low gas generation rate of the process condensate results in low flammability and takes more than 2 years to reach $25 \%$ of the LFL.

\section{References}

RPP-5926, 2006, Steady-State Flammable Gas Release Rate Calculation and Lower Flammability Level Evaluation for Hanford Tank Waste, Rev. 6, CH2M HILL Hanford Group, Inc., Richland, Washington.

RPP-8050, 2005, Lower Flammability Limit Calculations for Catch Tanks, IMUSTs, DST Annuli, Pit Structures, and Double-Contained Receiver Tanks in Tank Farms at the Hanford Site, Rev. 4-A, CH2M HILL Hanford Group, Inc., Richland, Washington.

RPP-PLAN-27610, 2006, Process Control Plan for 242-A Evaporator Campaigns 06-CR (Cold Run), Rev. 0B, CH2M HILL Hanford Group, Inc., Richland, Washington. 
Table E-1a. Chemical Composition of the Process Condensate for the Shutdown Mode and Startup Mode.

\begin{tabular}{|c|c|c|c|c|c|c|c|c|c|c|c|c|c|c|c|c|}
\hline & $\underset{(\mu \mathrm{g} / \mathbf{m L})}{\mathbf{N a}}$ & $\underset{(\mu \mathrm{g} / \mathrm{mL})}{\mathrm{Al}}$ & $\underset{(\mu \mathrm{g} / \mathrm{mL})}{\mathbf{F e}}$ & $\underset{(\mu \mathrm{g} / \mathrm{mL})}{\mathrm{Cr}}$ & $\underset{(\mu \mathrm{g} / \mathrm{mL})}{\mathrm{Ni}}$ & $\underset{(\mu \mathrm{g} / \mathrm{mL})}{\mathbf{K}}$ & $\underset{(\mu \mathrm{g} / \mathrm{mL})}{\mathrm{TOC}}$ & $\underset{(\mu \mathrm{g} / \mathrm{mL})}{\text { OH }}$ & $\begin{array}{c}\mathrm{NO}_{2} \\
(\mu \mathrm{g} / \mathrm{mL})\end{array}$ & $\begin{array}{c}\mathrm{NO}_{3} \\
(\mu \mathrm{g} / \mathrm{mL})\end{array}$ & $\underset{(\mu \mathrm{g} / \mathrm{mL})}{\mathrm{CO}_{3}}$ & $\begin{array}{c}\mathbf{P O}_{4} \\
(\mu \mathrm{g} / \mathrm{mL})\end{array}$ & $\begin{array}{c}\mathrm{SO}_{4} \\
(\mu \mathrm{g} / \mathrm{mL})\end{array}$ & $\underset{(\mu \mathrm{g} / \mathrm{mL})}{F}$ & $\underset{(\mu \mathrm{g} / \mathrm{mL})}{\mathrm{Cl}}$ & $\underset{(\mu \mathrm{g} / \mathrm{mL})}{\mathrm{NH}_{3}}$ \\
\hline \begin{tabular}{|l} 
Shutdown \\
mode
\end{tabular} & $1.15 \mathrm{E}-01$ & $3.70 \mathrm{E}-02$ & $1.00 \mathrm{E}-03$ & $1.00 \mathrm{E}-03$ & $1.00 \mathrm{E}-03$ & $1.00 \mathrm{E}-03$ & $2.16 \mathrm{E}+03$ & $1.66 \mathrm{E}-04$ & $6.08 \mathrm{E}-02$ & $1.13 \mathrm{E}-01$ & $1.00 \mathrm{E}-03$ & $1.00 \mathrm{E}-03$ & $1.00 \mathrm{E}-03$ & $1.00 \mathrm{E}-03$ & 1.00E-03 & $1.49 \mathrm{E}+02$ \\
\hline Startup mode & $1.15 \mathrm{E}-01$ & $3.70 \mathrm{E}-02$ & $1.00 \mathrm{E}-03$ & $1.00 \mathrm{E}-03$ & $1.00 \mathrm{E}-03$ & $1.00 \mathrm{E}-03$ & $8.36 \mathrm{E}+02$ & $1.66 \mathrm{E}-04$ & $6.08 \mathrm{E}-02$ & $1.13 \mathrm{E}-01$ & $1.00 \mathrm{E}-03$ & $1.00 \mathrm{E}-03$ & $1.00 \mathrm{E}-03$ & $1.00 \mathrm{E}-03$ & $1.00 \mathrm{E}-03$ & $1.49 \mathrm{E}+02$ \\
\hline
\end{tabular}

1. The process condensate data are taken from 06-01 campaign sample data, except that the TOC is an average of 55 gal of AFA liquid and process condensate.

2. Total inorganic carbon (TIC) data was used to derive $\mathrm{CO}_{3}$ : (TIC $\left.\times 5=\mathrm{CO}_{3}\right)$

Table E-1b. Radionuclide Composition and SpG for the Shutdown Mode and Startup Mode.

\begin{tabular}{|c|c|c|c|c|c|c|c|c|}
\hline $\begin{array}{c}\text { Radio nuclide } \\
\text { \& SpG }\end{array}$ & $\begin{array}{c}\mathrm{Sr}-89 / 90 \\
(\mu \mathrm{Ci} / \mathrm{g})\end{array}$ & $\begin{array}{c}\mathrm{Am}-241 \\
(\mu \mathrm{Ci} / \mathrm{g})\end{array}$ & $\begin{array}{l}\text { Pu-239 } \\
(\mu \mathrm{Ci} / \mathrm{g})\end{array}$ & $\begin{array}{l}\mathrm{Pu}-240 \\
(\mu \mathrm{Ci} / \mathrm{g})\end{array}$ & $\begin{array}{l}\mathrm{Pu}-238 \\
(\mu \mathrm{Ci} / \mathrm{g})\end{array}$ & $\begin{array}{l}\text { Cs-137 } \\
(\mu \mathrm{Ci} / \mathrm{g})\end{array}$ & $\underset{(\mathrm{g} / \mathrm{mL})}{\mathrm{SpG}}$ & $\begin{array}{l}\text { wt } \% \\
\text { Water }\end{array}$ \\
\hline Shutdown mode & $0.00 \mathrm{E}+00$ & $1.05 \mathrm{E}-09$ & $6.40 \mathrm{E}-10$ & $6.40 \mathrm{E}-10$ & $0.00 \mathrm{E}+00$ & $8.37 \mathrm{E}-07$ & 1.01 & $99 \%$ \\
\hline Startup mode & $0.00 \mathrm{E}+00$ & $1.05 \mathrm{E}-09$ & $6.40 \mathrm{E}-10$ & $6.40 \mathrm{E}-10$ & $0.00 \mathrm{E}+00$ & 8.37E-07 & 1.01 & $99 \%$ \\
\hline
\end{tabular}

Notes:

1. The process condensate data are taken from 06-01 campaign sample data.

2. Pu-239/240 was used for $\mathrm{Pu}-239$ and for $\mathrm{Pu}-240$. 
Table E-2. Derived Data for Hydrogen Generation Rate Model Calculations for the Shutdown Mode and Startup Mode.

\begin{tabular}{|c|c|c|c|c|c|c|c|c|c|c|c|c|}
\hline Tank & $\begin{array}{c}\text { Total } \\
\text { mass } \\
\mathbf{M} \\
(\mathbf{k g})\end{array}$ & $\begin{array}{c}\text { Liquid } \\
\text { in waste } \\
\text { (wt\%) }\end{array}$ & $\begin{array}{l}\text { Wetted } \\
\text { area } \\
\mathbf{A}_{\text {wet }} \\
\left(\mathbf{f t}^{2}\right)\end{array}$ & $\begin{array}{c}\text { Heat load } \\
\text { per kg } \\
\text { HL b/r }_{\text {b }} \\
\text { (watt } / \mathrm{kg} \text { ) }\end{array}$ & $\begin{array}{c}\text { Tank } \\
\text { heat load }^{b / r} \\
\text { H }_{L} \\
\text { (watt) }\end{array}$ & $\begin{array}{c}\text { Tank } \\
\text { heat load }^{2} \\
\text { H }_{\mathrm{L}} \text { alpha }^{2} \\
\text { (watt } / \mathrm{kg} \text { ) }\end{array}$ & $\begin{array}{c}\mathrm{NO}_{3} \\
\text { in liquid } \\
{\left[\mathrm{NO}_{3}\right]_{M}} \\
\left(\mathrm{~mole}_{\mathrm{L}} \mathrm{L}\right)\end{array}$ & $\begin{array}{c}\mathrm{NO}_{2} \\
\text { in liquid } \\
{\left[\mathrm{NO}_{2}\right]_{\mathrm{M}}} \\
(\mathrm{mole} / \mathrm{L})\end{array}$ & $\begin{array}{c}\text { Excess } \mathrm{Na} \\
\text { in liquid } \\
{[\mathrm{Na}]_{\mathrm{ex}}} \\
(\mathrm{mole} / \mathrm{mL})\end{array}$ & $\begin{array}{c}\text { OH } \\
\text { in liquid } \\
{[\mathrm{OH}]} \\
(\mathrm{mole} / \mathrm{L})\end{array}$ & $\begin{array}{c}\text { TOC } \\
\text { in liquid } \\
\text { [TOC]\% } \\
(w t \%)\end{array}$ & $\begin{array}{c}\text { Al } \\
\text { in liquid } \\
{[\mathbf{A l}] \%} \\
(\mathbf{w t} \%)\end{array}$ \\
\hline $\begin{array}{c}\text { Shutdown } \\
\text { mode }\end{array}$ & $3.82 E+04$ & $100 \%$ & 1846 & $3.96 \mathrm{E}-12$ & $1.51 \mathrm{E}-07$ & $7.35 \mathrm{E}-14$ & $1.82 \mathrm{E}-06$ & $1.32 \mathrm{E}-06$ & $1.86 \mathrm{E}-06$ & $1.66 \mathrm{E}-04$ & 0.21 & $3.66 \mathrm{E}-06$ \\
\hline Startup mode & $3.82 \mathrm{E}+04$ & $100 \%$ & 1846 & $3.96 \mathrm{E}-12$ & $1.51 \mathrm{E}-07$ & $7.35 \mathrm{E}-14$ & $1.82 \mathrm{E}-06$ & $1.32 \mathrm{E}-06$ & $1.86 \mathrm{E}-06$ & $1.66 \mathrm{E}-04$ & 0.08 & $3.66 \mathrm{E}-06$ \\
\hline
\end{tabular}

Note:

TOC $=$ total organic carbon

Table E-3. Calculated G Value and Hydrogen Generation Rate as Mole Per Unit Waste Weight and Volume for the Shutdown Mode and Startup Mode.

\begin{tabular}{|c|c|c|c|c|c|c|c|c|c|c|c|}
\hline Tank & $\begin{array}{c}\mathbf{E}_{\mathrm{H} 2} \\
\text { Efficiency of } \\
\mathbf{H}_{2} \text { by } \\
\text { corrosion }\end{array}$ & $\begin{array}{c}\text { G values } \\
\text { for water } \\
G_{\mathrm{H} 20}{ }^{b / r} \\
\left(\mathbf{H}_{2} / 100 \mathrm{eV}\right)\end{array}$ & $\begin{array}{c}\text { Total } \\
\text { G values } \\
\mathbf{G}_{\text {Tot }} \mathbf{b} / \mathbf{r} \\
\left(\mathbf{H}_{2} / 100 \mathrm{eV}\right)\end{array}$ & $\begin{array}{c}\text { G values } \\
\text { for water } \\
\mathbf{G}_{\mathrm{H} 20^{2 / \mathrm{pha}}} \\
\left(\mathrm{H}_{2} / \mathbf{1 0 0 \mathrm { eV }}\right)\end{array}$ & $\begin{array}{c}\text { Total } \\
\text { G values } \\
\mathbf{G}_{\text {Tor }}^{\text {alpha }} \\
\left(\mathrm{H}_{2} / 100 \mathrm{eV}\right)\end{array}$ & $\begin{array}{c}\text { HGR from } \\
\text { radiolysis } \\
\mathrm{RC}_{\mathrm{rad} / \mathrm{r}} \\
(\mathrm{mole} / \mathrm{kg}-\mathrm{d})\end{array}$ & $\begin{array}{l}\text { HGR from } \\
\text { radiolysis } \\
R_{\text {rad alpha }} \\
\text { (mole/kg-d) }\end{array}$ & $\begin{array}{l}\text { HGR from } \\
\text { thermolysis } \\
\text { RC } \\
\text { (molerm } \\
\text { (mg-d) }\end{array}$ & $\begin{array}{l}\text { HGR from } \\
\text { radiolysis } \\
R_{\text {rad }} \\
\left(\mathrm{mole}_{\mathbf{r}} / \mathrm{m}^{3}-\mathrm{s}\right)\end{array}$ & $\begin{array}{l}\text { HGR from } \\
\text { radiolysis } \\
\text { RC }_{\text {ad }} \text { alph } \\
\left(\mathrm{mole}^{3} \mathrm{~m}^{3}-\mathrm{s}\right)\end{array}$ & $\begin{array}{c}\text { HGR from } \\
\text { thermolysis } \\
\text { RC }_{\text {therm }} \\
\left(\mathrm{mole} / \mathrm{m}^{3}-\mathrm{s}\right)\end{array}$ \\
\hline Shutdown mode & 0.50 & 0.45 & 0.45 & 1.40 & 1.40 & $1.60 \mathrm{E}-14$ & $9.21 \mathrm{E}-16$ & $1.89 \mathrm{E}-10$ & $1.87 \mathrm{E}-16$ & $1.08 \mathrm{E}-17$ & $2.21 \mathrm{E}-12$ \\
\hline Startup mode & 0.50 & 0.45 & 0.47 & 1.40 & 1.41 & $1.67 \mathrm{E}-14$ & $9.28 \mathrm{E}-16$ & $3.28 \mathrm{E}-08$ & $1.95 \mathrm{E}-16$ & $1.08 \mathrm{E}-17$ & $3.83 \mathrm{E}-10$ \\
\hline
\end{tabular}

Note: HGR = hydrogen generation rate. 
Table E-4. Condensate Liquid Waste for Input Data for Flammability Calculation on Shutdown and Startup Modes for the 242-A Evaporator C-A-1 Vessel.

\begin{tabular}{|c|c|c|c|c|c|c|c|c|c|c|c|c|}
\hline Tanks & $\begin{array}{c}\text { Total } \\
\text { Tank } \\
\text { Volume } \\
\left(\mathrm{ft}^{3}\right)\end{array}$ & $\begin{array}{c}\text { Head } \\
\text { space } \\
\text { Temp } \\
\left({ }^{\circ} \mathrm{C}\right)\end{array}$ & $\begin{array}{c}\text { Molar } \\
\text { Specific } \\
\text { Volume } \\
\text { (L/mole) }\end{array}$ & $\begin{array}{c}\text { Filled } \\
\text { waste } \\
\text { fraction } f\end{array}$ & $\begin{array}{l}\text { Ratio of } \\
\text { Wetted } \\
\text { Area and } \\
\text { Volume } \\
\left(\mathrm{ft}^{2} / \mathrm{ft}^{3}\right)\end{array}$ & $\begin{array}{c}\text { Ratio of } \\
\text { Surface } \\
\text { Area and } \\
\text { Volume } \\
\left(\mathrm{ft}^{2} / \mathrm{ft}^{3}\right)\end{array}$ & $\begin{array}{c}\mathbf{R C}_{\mathrm{rad}} \\
\left(\mathrm{mole} / \mathbf{m}^{3}-\mathrm{s}\right) \\
\mathbf{H}_{2} \text { from } \\
\text { Radiolysis }\end{array}$ & $\begin{array}{c}\mathrm{RC}_{\text {therm }} \\
\left(\mathrm{mole} / \mathrm{m}^{3}-\mathrm{s}\right) \\
\mathrm{H}_{2} \text { from } \\
\text { Thermolysis }\end{array}$ & $\begin{array}{c}\mathrm{N}_{2} \mathrm{O} \\
\text { Release } \\
\text { Rate } \\
\left.\operatorname{Rr}^{2} \mathbf{N}_{2} \mathrm{O}\right) \\
(\mathbf{c f m})\end{array}$ & $\begin{array}{l}\text { Ammonia } \\
\text { Liquid } \\
\text { Concen. } \\
\text { (mole/L) }\end{array}$ & $\begin{array}{c}\text { Liquid } \\
\text { Henry } \\
\text { Constant } \\
K_{\mathbf{H}} \\
(\mathbf{M} / \mathbf{a t m})\end{array}$ & $\begin{array}{c}\text { Ammonia } \\
\text { Transport } \\
\text { Coefficient h } \\
(\mathrm{m} / \mathrm{sec})\end{array}$ \\
\hline $\begin{array}{c}\text { Shutdown } \\
\text { mode }\end{array}$ & 5611 & 15 & 28.2 & 0.24 & 0.74 & 0.19 & $1.98 \mathrm{E}-16$ & $2.21 \mathrm{E}-12$ & $1.87 \mathrm{E}-03$ & $8.75 \mathrm{E}-03$ & 98.9 & $4.88 \mathrm{E}-06$ \\
\hline Startup mode & 5611 & 71 & 28.2 & 0.62 & 0.53 & 0.07 & $2.06 \mathrm{E}-16$ & $3.83 \mathrm{E}-10$ & $1.87 \mathrm{E}-03$ & $8.75 \mathrm{E}-03$ & 10.0 & $4.88 \mathrm{E}-06$ \\
\hline
\end{tabular}

Table E-5. Results of Flammability Calculation on Shutdown and Startup Modes for the 242-A Evaporator C-A-1 Vessel.

\begin{tabular}{|c|c|c|c|c|c|c|c|c|c|c|c|}
\hline Tanks & $\begin{array}{l}\text { Filled waste } \\
\text { fraction } f\end{array}$ & $\begin{array}{c}\mathrm{RC}_{\text {corr }} \\
\mathrm{H} 2 \text { from } \\
\text { Corrosion } \\
\left(\mathrm{mole} / \mathrm{m}^{3}-\mathrm{s}\right)\end{array}$ & $\begin{array}{c}\text { Ammonia } \\
\text { transport } \\
\text { constant } k_{1} \\
\left(\min ^{-1}\right)\end{array}$ & $\begin{array}{c}\text { Ammonia } \\
\text { transport } \\
\text { constant } \mathbf{k}_{\mathbf{2}} \\
(\mathbf{M} / \mathbf{m i n})\end{array}$ & $\begin{array}{c}\mathrm{U}_{\mathrm{H} 2} \\
\text { Unit rate of } \\
\text { hydrogen } \\
\left(\mathrm{mole} / \mathrm{m}^{3}-\mathrm{s}\right)\end{array}$ & $\begin{array}{c}\mathrm{U}_{\mathrm{CH} 4} \\
\text { Unit rate of } \\
\text { methane } \\
\left(\text { mole } / \mathrm{m}^{3}-\mathrm{s}\right)\end{array}$ & $\begin{array}{c}\text { Steady-state } \\
\text { EQ NH} \\
\text { Concen. } \\
(\%)\end{array}$ & $\begin{array}{c}\text { Steady } \\
\text { State } \\
\mathbf{H}_{\mathbf{2}} \mathbf{L F L} \\
(\%)\end{array}$ & $\begin{array}{c}\text { Steady } \\
\text { State CH } \\
\text { LFL (\%) }\end{array}$ & $\begin{array}{c}\text { Steady } \\
\text { State NH } \\
\text { LFL (\%) }\end{array}$ & $\begin{array}{c}\text { Steady } \\
\text { State LFL } \\
\text { at B.B. } \\
(\%)\end{array}$ \\
\hline Shutdown mode & 0.24 & $3.12 \mathrm{E}-09$ & $1.34 \mathrm{E}-01$ & $5.02 \mathrm{E}-07$ & $3.12 \mathrm{E}-09$ & $2.21 \mathrm{E}-13$ & 0.01 & $1.1 \%$ & $0.00 \%$ & $0.1 \%$ & $1.2 \%$ \\
\hline Startup mode & 0.62 & $1.88 \mathrm{E}-09$ & $1.61 \mathrm{E}-02$ & $5.02 \mathrm{E}-07$ & $2.26 \mathrm{E}-09$ & $3.83 \mathrm{E}-11$ & 0.09 & $5.0 \%$ & $0.07 \%$ & $0.6 \%$ & $5.6 \%$ \\
\hline
\end{tabular}

Notes:

$\mathrm{BB}$ or $\mathrm{bb}=$ barometric breathing.

LFL = lower flammability limit. 
Table E-6. Results of Time to $25 \%$ and $100 \%$ of the LFL Calculation on Shutdown and Startup Modes for the 242-A Evaporator C-A-1 Vessel.

\begin{tabular}{|c|c|c|c|c|c|c|c|c|c|}
\hline Tanks & $\begin{array}{l}\text { Filled waste } \\
\text { fraction } f\end{array}$ & $\begin{array}{c}\text { Time to } \\
\text { Reach } \\
25 \% \text { LFL } \\
\text { at BB vent } \\
\text { (days) }\end{array}$ & $\begin{array}{c}\text { Time to } \\
\text { Reach } \\
100 \% \text { LFL } \\
\text { at BB vent } \\
\text { (days) }\end{array}$ & $\begin{array}{l}\text { Time to } \\
\text { Reach } \\
25 \% \text { LFL } \\
\text { at Zero } \\
\text { vent (days) }\end{array}$ & $\begin{array}{l}\text { Time to } \\
\text { Reach } \\
100 \% \text { LFL } \\
\text { at Zero } \\
\text { vent (days) }\end{array}$ & $\begin{array}{c}\text { Vent Rate keep } \\
\text { below } 25 \% \text { LFL } \\
\text { DomeVol\% per } \\
\text { day }\end{array}$ & $\begin{array}{c}\text { Vent rate } \\
\text { keep } \\
\text { below } \\
25 \% \text { LFL } \\
\text { (cfh) }\end{array}$ & $\begin{array}{c}\text { Vent Rate keep } \\
\text { below } 100 \% \text { LFL } \\
\text { DomeVol\% per } \\
\text { day }\end{array}$ & $\begin{array}{c}\text { Vent rate } \\
\text { keep } \\
\text { below } \\
100 \% \text { LFL } \\
\text { (cfh) }\end{array}$ \\
\hline Shutdown mode & 0.24 & not occur & not occur & 2000 & 2000 & $0.45 \%$ & L.T. bb & $0.45 \%$ & L.T. bb \\
\hline Startup mode & 0.62 & not occur & not occur & 1079 & 1755 & $0.45 \%$ & L.T. $b b$ & $0.45 \%$ & L.T. bb \\
\hline
\end{tabular}

Note: The calculation is terminated at 2,000 days.

$\mathrm{BB}$ or $\mathrm{bb}=$ barometric breathing.

LFL = lower flammability limit.

L.T. = less than. 
RPP-CALC-29700 REV 1

\section{APPENDIX F}

ESTIMATE OF CARBON FRACTION IN DOW CORNING 1520 SILICONE ANTIFOAM 
RPP-CALC-29700 REV 1

This page intentionally left blank.

F-ii 


\title{
APPENDIX F \\ ESTIMATE OF CARBON FRACTION IN \\ DOW CORNING 1520 SILICONE ANTIFOAM
}

\author{
K. R. Sandgren
}

In order to evaluate the flammable gas generation rate in the evaporator vessel it is necessary to know the organic carbon content. An additive is sometimes used to prevent foaming in the evaporator vessel. The additive is Dow Corning 1520 Silicone Antifoam. To estimate the organic carbon in the evaporator vessel, the carbon content of the anti-foaming additive must be known. Dow Corning 1520 Silicone Antifoam is a proprietary product and its exact makeup is unknown.

The material safety data sheet (MSDS) for the product provides some information. The MSDS lists the following constituents:

\begin{tabular}{|l|c|}
\hline Component Name & Weight \% \\
\hline Water & $>60.0$ \\
\hline Polydimethylsiloxane & $15.0-40.0$ \\
\hline Methylated silica & $1.0-5.0$ \\
\hline Methylcellulose & $1.0-5.0$ \\
\hline
\end{tabular}

These estimates can be improved by examining the product information sheet (available at the Dow Corning website) for the anti-foaming agent. The product information sheet says the additive is " $20 \%$ active silicone emulsion." Thus a best estimate of polydimethylsiloxane (PDMS) in the additive would be $20 \mathrm{wt} \%$. The product information sheet also says that the total "non-volatile content" of the product is $24 \mathrm{wt} \%$. Thus it can be concluded that the total amount of methylcellulose and methylated silica in the product is $4 \%$.

PDMS is commonly defined as $\left(\mathrm{H}_{3} \mathrm{C}\right)\left[\mathrm{SiO}\left(\mathrm{CH}_{3}\right)_{2}\right]_{n} \mathrm{Si}\left(\mathrm{CH}_{3}\right)_{3}$ where $\mathrm{n}$ is the number of monomers in the polymer. This definition assumes the common form of PDMS. To be precise PDMS is $(\mathrm{R})\left[\mathrm{SiO}\left(\mathrm{CH}_{3}\right)_{2}\right]_{\mathrm{n}} \mathrm{Si}(\mathrm{R})(\mathrm{R}$ ' $)(\mathrm{R}$ ',') where $\mathrm{R}, \mathrm{R}$ ', R', and R', are any of a number of carbon groups. For the analysis that follows, methyl groups will be assumed since that is the most common form of PDMS.

In order to estimate the carbon content of PDMS the number of monomers in the polymer must be known. To maximize the carbon content, the number of monomers will be assumed to be 
two. The carbon fraction of $\left(\mathrm{H}_{3} \mathrm{C}\right)\left[\mathrm{SiO}\left(\mathrm{CH}_{3}\right)_{2}\right]_{2} \mathrm{Si}\left(\mathrm{CH}_{3}\right)_{3}$ can now be estimated using the atomic weights of the constituents.

PDMS carbon fraction (where $\mathrm{n}=2$ )

$$
[(8)(12.01)] /[(8)(12.01)+(3)(28.09)+(2)(16.00)+(24)(1.008)]=0.406
$$

where:

$$
\begin{array}{ll}
(8)(12.01) & =\text { (number of carbon atoms)(atomic weight of carbon) } \\
(3)(28.09) & =\text { (number of silicon atoms)(atomic weight of silicon) } \\
(2)(16.00) & =\text { (number of oxygen atoms)(atomic weight of oxygen) } \\
(24)(1.008) & =\text { (number of hydrogen atoms)(atomic weight of hydrogen). }
\end{array}
$$

As the number of polymers increases the carbon fraction decreases to as low as 0.324 .

The carbon fraction of methylated silica and methylcellulose can be estimated similarly where methylated silica is $\mathrm{H}_{3} \mathrm{CSiO}_{2}$ and methylcellulose is cellulose $\left(\mathrm{C}_{6} \mathrm{H}_{10} \mathrm{O}_{5}\right)_{n}$ with as many as three hydroxyl groups $(\mathrm{OH})$ of each monomer having the hydrogen atoms replaced with methyl groups $\left(\mathrm{CH}_{3}\right)$ forming $\left(\mathrm{OCH}_{3}\right)$. In order to maximize the carbon fraction, it is assumed that all three available hydroxyl groups have been replaced. Thus, methylcellulose is $\left(\mathrm{C}_{9} \mathrm{H}_{16} \mathrm{O}_{5}\right)_{n}$. Since the fraction of carbon in methylated silica is much less than that in the methylcellulose, the remaining $4 \%$ of non-volatile content will be assumed to be methylcellulose. The carbon fraction of methylcellulose can now be estimated.

Methylcellulose carbon fraction

$$
[(9)(12.01)] /[(9)(12.01)+(16)(1.008)+(5)(16.00)] \quad=0.529
$$

where:

$$
\begin{aligned}
& (9)(12.01) \quad=\text { (number of carbon atoms)(atomic weight of carbon) } \\
& (16)(1.008) \quad=\text { (number of hydrogen atoms)(atomic weight of hydrogen) } \\
& (5)(16.00) \quad=\text { (number of oxygen atoms)(atomic weight of oxygen). }
\end{aligned}
$$

Note that the number of monomers doesn't matter in methylcellulose since the proportions of all the constituents remain the same as the chain length grows.

The total organic content of the anti-foaming additive can now be estimated using the carbon fractions calculated above:

Weight percent total organic content

$$
(20 w t \%)(0.406)+(4 w t \%)(0.529)=10 \%
$$


where:

$$
\begin{array}{ll}
20 \mathrm{wt} \% & =\text { weight percent of PDMS } \\
0.406 & =\text { carbon fraction in PDMS } \\
4 \mathrm{wt} \% & =\text { weight percent remaining non-volatile content (methylcellulose) } \\
0.529 & =\text { carbon fraction in methylcellulose. }
\end{array}
$$

However, there is uncertainty in this value. It is possible that the PDMS polymer could be terminated with carbon groups other than methyl groups (vinyl groups are also common but other groups are possible). If it is assumed that the polymer is terminated with vinyl groups $\left(\mathrm{C}_{2} \mathrm{H}_{3}\right)$ the carbon fraction can be similarly calculated. The carbon fraction of $\left(\mathrm{H}_{3} \mathrm{C}_{2}\right)\left[\mathrm{SiO}\left(\mathrm{CH}_{3}\right)_{2}\right]_{2} \mathrm{Si}\left(\mathrm{C}_{2} \mathrm{H}_{3}\right)_{3}$ is estimated as:

PDMS carbon fraction (where $\mathrm{n}=2$ )

$$
[(12)(12.01)] /[(12)(12.01)+(3)(28.09)+(2)(16.00)+(24)(1.008)]=0.506 \text {. }
$$

The total organic content assuming vinyl groups can now be estimated using the carbon fractions calculated above:

Weight percent total organic content

$$
(20 w t \%)(0.506)+(4 w t \%)(0.529)=12.2 \%
$$

where:

$$
\begin{array}{ll}
20 \mathrm{wt} \% & =\text { weight percent of PDMS } \\
0.506 & =\text { carbon fraction in vinyl terminated PDMS } \\
4 \mathrm{wt} \% & =\text { weight percent remaining non-volatile content (methylcellulose) } \\
0.529 & =\text { carbon fraction in methylcellulose. }
\end{array}
$$

It is unlikely that the carbon fraction would be modified beyond this for an antifoaming application since the solubility of the PDMS would decrease as long chained carbon groups are substituted into the termination points. However, to conservatively account for this uncertainty the total organic content in the anti-foaming additive will be rounded up to $13 \%$. 
RPP-CALC-29700 REV 1

This page intentionally left blank. 
RPP-CALC-29700 REV 1

\section{APPENDIX G}

TECHNICAL BASIS WHY ASSUMING ONE DRUM OF ANTIFOAMING AGENT IN THE C-A-1 EVAPORATOR VESSEL IS REASONABLY CONSERVATIVE 
RPP-CALC-29700 REV 1

This page intentionally left blank.

G-ii 


\title{
APPENDIX G
}

\section{TECHNICAL BASIS WHY ASSUMING ONE DRUM OF ANTIFOAMING AGENT IN THE C-A-1 EVAPORATOR VESSEL IS REASONABLY CONSERVATIVE}

\author{
J. M. Conner
}

Assuming that there is one drum (55 gal) of antifoaming agent (AFA) (20\% active Dow Corning 1520 -US) in the 242-A Evaporator C-A-1 vessel $(26,000$ gal) is considered reasonably conservative based on the following.

- Maximum Injection Rate - The maximum injection rate is $0.1 \mathrm{gal} / \mathrm{min}$ and the minimum dilution allowed per procedure is one part water to one part AFA by volume (or $50 \%$ dilution). Therefore, the injection time for one drum (55 gal) at the maximum injection rate is over 18 hours. The actual injection rate is typically much lower.

- Steady State - Assuming production of slurry at $33 \mathrm{gal} / \mathrm{min}$ (the low slurry flow alarm set point), approximately 35,000 gal of slurry would be processed through the 242-A Evaporator in 18 hours. That is, at steady state, the maximum injection rate and the minimum slurry rate result in an AFA concentration of less than one drum/C-A-1 evaporator vessel volume. The slurry rate is usually higher, and the injection rate is usually lower.

- Recycle Experience - Foaming problems were anticipated in the 07-01 campaign based on the boil-down. In addition, the campaign processing strategy included recycle of dilute slurry back to the feed tank for reconcentration. Seven drums of AFA were used in "Phase 1" of Campaign 07-01, when slurry was recycled to 241-AW-102. Double-shell tank 241-AW-102 was reduced to $139 \mathrm{in}$. With $11 \mathrm{in}$. of solids, that is $128 \mathrm{in}$. of supernatant or approximately 350,000 gal. So the ratio of AFA to feed was approximately one drum $/ 50,000$ gal. At slurry conditions, the ratio would be almost one drum/C-A-1 evaporator vessel volume. However, that feed was mixed with fresh feed from 241-AP-104 before being fed to the 242-A Evaporator.

- Startup and Recirculation - Whenever slurry is not being discharged and AFA is being injected, the AFA concentration in the system is increasing. Two of these times are during startup and when in recirculation. Startup and recirculation could go for days. Practically, however, AFA injection during these times is limited, as the injection rate during startup is below the maximum, and the practice is to shut off AFA when in recirculation.

Therefore, an assumption of one drum of AFA in the C-A-1 evaporator vessel $(26,000 \mathrm{gal})$ is reasonably conservative with the expected AFA concentration in the C-A-1 evaporator vessel below this. 
RPP-CALC-29700 REV 1

This page intentionally left blank.

G-2 
RPP-CALC-29700 REV 1

APPENDIX H

CALCULATION REVIEW CHECKLIST

$\mathrm{H}-\mathrm{i}$ 
RPP-CALC-29700 REV 1

This page intentionally left blank.

H-ii 


\title{
APPENDIX H
}

\section{CALCULATION REVIEW CHECKLIST}

\author{
RPP-CALC-29700 REV 1
}

Calculation Review Checklist.

Calculation Reviewed: RPP-CALC-29700, Rev. 1

Scope of Review: Main text and new/updated input data listed for flammability evaluations

Engineer/Analyst: T. A. Hu

This document consists of 123 pages and the following attachments (if applicable):

Yes No NA*

[X] [ ] [ ] 1. Analytical and technical approaches and results are reasonable and appropriate.

[X] [] [ ] 2. Necessary assumptions are reasonable, explicitly stated, and supported.

[] [ ] [X] 3. Ensure calculations that use software include a paper printout, microfiche, $\mathrm{CD}$ ROM, or other electronic file of the input data and identification to the computer codes and versions used, or provide alternate documentation to uniquely and clearly identify the exact coding and execution process.

[X] [ ] [ ] 4. Input data were checked for consistency with original source information.

[] [ ] [X] 5. Key input data (e.g., dimensions, performance characteristics) that may affect equipment design is identified.

[X] [ ] [] 6. For both qualitative and quantitative data, uncertainties are recognized and discussed.

[ ] [] [X] 7. Mathematical derivations were checked, including dimensional consistency of results.

[X] [ ] [ ] 8. Calculations are sufficiently detailed such that a technically qualified person can understand the analysis without requiring outside information.

[] [ ] [X] 9. Software verification and validation are addressed adequately.

[X] [ ] [] 10. Limits/criteria/guidelines applied to the analysis results are appropriate and referenced.

[X] [ ] [ ] 11. Conclusions are consistent with analytical results and applicable limits.

[X] [] [ ] 12. Results and conclusions address all points in the purpose.

[X] [ ] [ ] 13. Referenced documents are retrievable or otherwise available.

[X] [ ] [ ] 14. The version or revision of each reference is cited, as appropriate.

[] [] [] 15. The document was prepared in accordance with Attachment A, "Calculation Format and Preparation Instructions."

[ ] [ ] [X] 16. Impacts on requirements have been assessed and change documentation initiated to incorporate revisions to affected documents, as appropriate.

[] [ ] [X] 17. The design media matches the calculations.

[X] [ ] [ ] 18. All checker comments have been dispositioned.

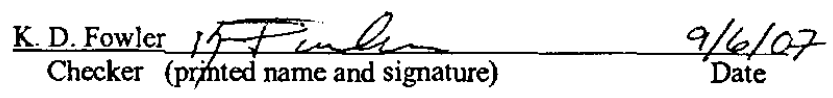

* If No or NA is chosen, an explanation must be provided on or attached to this form. 
RPP-CALC-29700 REV 1

RPP-CALC-29700 REV 1

Calculation Reviewed: RPP-CALC-29700, Rev. 1

\begin{tabular}{|l|l|}
\hline Item & \multicolumn{1}{|c|}{ Comment } \\
\hline 3 & $\begin{array}{l}\text { Only new/revised input data as documented in text is included in scope of review. Spreadsheets } \\
\text { are referenced in the document text, however, review does not have access to files. }\end{array}$ \\
\hline 5 & $\begin{array}{l}\text { The purpose of this calculation is not equipment design. The calculation models potential } \\
\text { flammable gas generation and accumulation in the existing 242-A facility. }\end{array}$ \\
\hline 7 & $\begin{array}{l}\text { No new mathematical derivations included in this revision. Models were previously derived in } \\
\text { HNF-3851, RPP-5926, and RPP-8050. }\end{array}$ \\
\hline 9 & $\begin{array}{l}\text { Software verification and validation were not included in the review scope. Review does not have } \\
\text { access to files. }\end{array}$ \\
\hline 16 & $\begin{array}{l}\text { This calculation supports the 242-A Evaporator DSA. Results/conclusions used to support DSA } \\
\text { changes have been reviewed by NS\&L. In accordance with TFC-ENG-SB-C-01, safety basis } \\
\text { changes are prepared by NS\&L. }\end{array}$ \\
\hline 17 & Reviewer does not have access to electronic files used for calculation. \\
\hline
\end{tabular}




\section{RPP-CALC-29700 REV 1}

\section{Calculation Review Checklist.}

Calculation Reviewed: RPP-CALC-29700,Rev. 1

Scope of Review: Three drum AFA addition calculation check

(e.g., document section or portion of calculation)

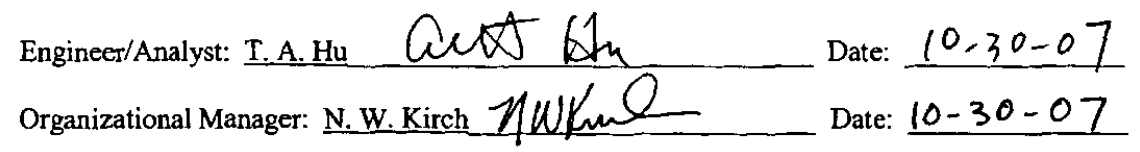

This document consists of pages and the following attachments (if applicable):

Yes No NA*

[X] [ ] [ ] 1. Analytical and technical approaches and results are reasonable and appropriate.

[X] [ ] [] 2. Necessary assumptions are reasonable, explicitly stated, and supported.

[] [ ] [X] 3. Ensure calculations that use software include a paper printout, microfiche, $\mathrm{CD}$ ROM, or other electronic file of the input data and identification to the computer codes and versions used, or provide alternate documentation to uniquely and clearly identify the exact coding and execution process.

[X] [ ] [ ] 4. Input data were checked for consistency with original source information.

[ ] [ ] [X] 5. Key input data (e.g., dimensions, performance characteristics) that may affect equipment design is identified.

[] [ ] [ $[\mathrm{X}] 6$. For both qualitative and quantitative data, uncertainties are recognized and discussed.

[ ] [ ] [X] 7. Mathematical derivations were checked, including dimensional consistency of results.

[X] [] [] 8. Calculations are sufficiently detailed such that a technically qualified person can understand the analysis without requiring outside information.

[] [ ] [X] 9. Software verification and validation are addressed adequately.

[] [ ] [X] 10. Limits/criteria/guidelines applied to the analysis results are appropriate and referenced.

[X] [ ] [ ] 11. Conclusions are consistent with analytical results and applicable limits.

[X] [ ] [ ] 12. Results and conclusions address all points in the purpose.

[X] [ ] [ ] 13. Referenced documents are retrievable or otherwise available.

[X] [ ] [ ] 14. The version or revision of each reference is cited, as appropriate.

[] [ ] [X] 15. The document was prepared in accordance with Attachment A, "Calculation Format and Preparation Instructions."

[ ] [ ] [X] 16. Impacts on requirements have been assessed and change documentation initiated to incorporate revisions to affected documents, as appropriate.

[] [ ] [X] 17. The design media matches the calculations.

[X] [] [] 18. All checker comments have been dispositioned.

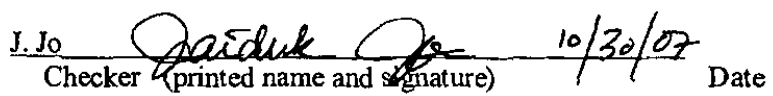

* If No or NA is chosen, an explanation must be provided on or attached to this form. 
RPP-CALC-29700 REV 1

Calculation Reviewed: RPP-CALC-29700, Rev, 1

\begin{tabular}{|l|l|}
\hline Item & \multicolumn{1}{|c|}{ Comment } \\
\hline 3 & $\begin{array}{l}\text { Only new/revised input data as documented in text is included in scope of review. Spreadsheets } \\
\text { are referenced in the document text, however, review does not have access to files. }\end{array}$ \\
\hline 5 & $\begin{array}{l}\text { The purpose of this calculation is not equipment design. The calculation models potential } \\
\text { flammable gas generation and accumulation in the existing 242-A facility. }\end{array}$ \\
\hline 7 & $\begin{array}{l}\text { No new mathematical derivations included in this revision. Models were previously derived in } \\
\text { HNF-3851, RPP-5926, and RPP-8050. }\end{array}$ \\
\hline 9 & $\begin{array}{l}\text { Software verification and validation were not included in the review scope. Review does not have } \\
\text { access to files. }\end{array}$ \\
\hline 16 & $\begin{array}{l}\text { This calculation supports the 242-A Evaporator DSA. Results/conclusions used to support DSA } \\
\text { changes have been reviewed by NS\&L. In accordance with TFC-ENG-SB-C-01, safety basis } \\
\text { changes are prepared by NS\&L. }\end{array}$ \\
\hline 17 & Reviewer does not have access to electronic files used for calculation. \\
\hline$-\cdots$ & Only three drum AFA addition calculation was checked. \\
\hline
\end{tabular}

